\title{
The Neotropical species of the genus Osoriellus FAgEL, 1959 (Coleoptera: Staphylinidae: Osoriinae)
}

\author{
With 127 figures
}

ULRICH IRMLER ${ }^{1}$

${ }^{1}$ Institut für Ökosystemforschung, Abt. Angewandte Ökologie, Universität, Olshausenstrasse 40, 24098 Kiel, Germany. - uirmler@ ecology.uni-kiel.de

Published on 2014-12-15

\section{Summary}

In this study on the Neotropical osorine complex (species formerly placed under the genus Osorius) all species are described and keys to the species are provided that are now included in the genus Osoriellus. Ten species groups were separated: Osoriellus-coronatus-group with O. coronatus as new species; O.-laeviusculus-group containing 2 species with O. schubarti as new species; O.-oculatus-group containing 5 species with O. hanagarthi, O. ocularis, O. denticornis and O. sexdentatus as new species; O.-bicornis-group with 8 new species O. bicornis, O. spinosus, O. corniculatus, O. bovis, O. cornutus, O. sinuatus, O. sinuatoangularis, and O. subsinuatus; O.-hirtulus-group with 6 species including O. setulosus, O. setifer, O. pubicollis, O. setosus, and O. pubescens as new species; O.-granarius-group containing three new species O.granarius, O. cornifrons, and O.granarius; O.-guiananus-group with 8 species including O. diversus, O. macrops, O. longipunctatus, O. melancholicus, and O. silvaticus as new species; O.-mrazi-group with the single new species O. mrazi; O.-s. str.-group containing 51 species with O. punctatellus, O. indescriptus, O. coruscus, O. luteus, O. asperatus, O. coriaceus, O. latitibialis, O. grossopunctatus, O. surinamensis, O. flaveolus, O. huggerti, O. obtusicollis, O. levyi, O. loksai, O. bicolor, O. ashei, O. humicola, O. boliviensis, O. parumpunctatus, O. tuxtlae, O. multipunctatus, O. triangulatus, O. majusculus, O. trapezoides, O. rubripennis, O. seriatus, O. verhaaghi, O. fumarius, O. caliginosus, O. rougemonti, and $O$. opacus as new species; remaining-species-group with 20 species including O. orbiculatus, O. opticus, O. digitatus, O. acutus, O. rectangulus, O. rufescens, O. loreti, O. adustus, O. lescheni, O. infuscatus, O. opacinotus, and O. sticticus as new species. The species O. acupunctus (BERNHAUER, 1933) and O. ogloblini (BernhaUer 1933) are syonym to O. argentinus (BERnHAUER, 1911), O. laeviceps (Notman, 1925 ) is synonym to O. eggersi (Bernhauer, 1904), O. mundus (Sharp, 1887) is synonym to O. latipes (GravenHORst, 1806), O. lynchi (Bernhauer, 1933) is synonym to O. neotropicus (Bernhauer, 1908). Overall, 71 species are newly described contributing to the 105 species of the genus in the Neotropical region. The ten species groups, geographic aspects and the species richness of the genus are discussed.

\section{Keywords}

Neotropis, new species, geographic distribution, Osoriinae, biodiversity 


\section{Zusammenfassung}

In dieser Arbeit über den neotropischen Osorius Komplex (Arten, die früher unter der Gattung Osorius beschrieben wurden) werden die Arten der Gattung Osoriellus beschrieben und Schlüssel zu ihrer Bestimmung geliefert. Zehn Arten Gruppen werden unterschieden: Osoriellus-coronatus-Gruppe mit O. coronatus als neue Art; O.-laeviusculus-Gruppe enthält 2 Arten mit O. schubarti als neue Art; O.-oculatus-Gruppe enthält 5 Arten mit O. hanagarthi, O. ocularis, O. denticornis und O. sexdentatus als neue Arten; O.-bicornis-Gruppe mit den 8 neuen Arten O. bicornis, O. spinosus, O. corniculatus, O. bovis, O. cornutus, O. sinuatus, O. sinuatoangularis, und O. subsinuatus; O.-hirtulus-Gruppe mit 6 Arten einschließlich O. setulosus, O. setifer, O. pubicollis, O. setosus und O.pubescens als neue Arten; O.-granarius-Gruppe enthält die 3 neuen Arten O. granarius, O. cornifrons und O. granarius; O.-guiananus-Gruppe mit 8 Arten einschließlich O. diversus, O. macrops, O. longipunctatus, O. melancholicus und O. silvaticus als neue Arten; O.-mrazi-Gruppe mit der einzigen neuen Art O. mrazi; O.-s. str.-Gruppe enthält 51 Arten mit O. punctatellus, O. indescriptus, O. coruscus, O. luteus, O. asperatus, O. coriaceus, O. latitibialis, O. grossopunctatus, O. surinamensis, O. flaveolus, O. huggerti, O. obtusicollis, O. levyi, O. loksai, O. bicolor, O. ashei, O. humicola, O. boliviensis, O. parumpunctatus, O. tuxtlae, O. multipunctatus, O. triangulatus, O. majusculus, O. trapezoides, O. rubripennis, O. seriatus, O. verhaaghi, O. fumarius, O. caliginosus, O. rougemonti und O. opacus als neue Arten; Gruppe der restlichen Arten mit 20 Arten einschließlich O. orbiculatus, O. opticus, O. digitatus, O. acutus, O. rectangulus, O. rufescens, O. loreti, O. adustus, O. lescheni, O. infuscatus, O. opacinotus und O. sticticus als neue Arten. Die Arten O. acupunctus (Bernhauer, 1933) und O. ogloblini (Bernhauer 1933) sind syonym zu O. argentinus (Bernhauer, 1911), O. laeviceps (Notman, 1925) ist synonym zu O. eggersi (Bernhauer, 1904), O. mundus (Sharp, 1887) zu O. latipes (Gravenhorst, 1806) und O. lynchi (Bernhauer, 1933) zu O. neotropicus (Bernhauer, 1908). Insgesamt enthält die Gattung Osoriellus damit 105 Arten in der Neotropis, von denen 71 Arten neu beschrieben werden. Die zehn Arten Gruppen, geographische und ökologische Aspekte sowie Artenzahlen in der Gattung werden diskutiert.

\section{Stichwörter}

Neotropis, neue Arten, geographische Verbreitung, Osoriinae, Biodiversität

\section{Introduction}

According to FAGEL (1959), the Osorius-complex includes the species of the tribe Osoriini with spines on the outer edge of the protibia and geniculate antennae. In the African fauna, FAGEL (1959) separated five genera. In a preliminary overview, IRMLER (2010) mentioned 8 genera in the Neotropical region with one species each in the genera Ouloglene Notman, 1925, Oryssoma Notman, 1925, and Anancosorius Bernhauer, 1908, 35 species in the genus Osorius Guérin-Méneville 1829, and 18 species in the genus Antillosorius IRMLER, 2010. The genera Osoriocanthus FAGEL, 1959, Neosorius FAGEL, 1959 and Osoriellus FAGEL, 1959 have been still waiting for a detailed investigation.

In the present study, the genus Osoriellus is presented with all species that were not included in the genus Osorius and Antillosorius by IrmLer (2010), but formerly described under the genus Osorius in the Neotropical fauna. According to FAGEL (1959), the genus Osoriellus is characterised by an asymmetric aedeagus with lateral opening, direct insertion of spines on the outer edge of the protibia and the posterior face of the protibia with setation, but without spines. For the African region, Herman (2001) mentioned 15 Osoriellus species. IrmLer (2010) already discussed the problems with the genus Osoriellus in the Neotropical region, which could not be solved in the present study. Thus, the remaining species that were not included in the genus Osorius or Antillosorius are now placed to the genus Osoriellus. These species are characterised by the absence of spines on the posterior face of the protibia and a narrow pronotal margin even at the posterior angles. However, many Neotropical Osoriellus species have a digitate outer edge of the protibia and a symmetric aedeagus with apical opening. It was not possible to define different genera regarding the length of the protibial digits or symmetry of the aedeagus. Therefore, only species groups are established and their characteres are discussed.

At present the Neotropical fauna contributes with 105 species to the genus Osoriellus with a total of 71 new and 5 synonymised species. Ten species groups are differentiated regarding specific structures of the abdominal segements, clypeal spines, pubescence, the aedeagus and the protibial digits. The study shows that this number is by far not representing the complete number of the Neotropical species in the genus. Many specimens could not be placed to one of the newly described species, because they were only presented by single females. It can be supposed that the genus is one of the species-richest genera in the Neotropical osorine fauna. The present study provides the description of the species and speciesgroups, keys to the species of the species groups and a discussion on the differentiation of the species groups and the geographic distribution. The type specimens of Osorius exalatus BLACKWELDER, 1943 and O. micropterus BLACKWELDER, 1943 were examined. They cannot be placed to the genera Osorius or Osoriellus. This will be discussed in a following paper. 


\section{Material and methods}

The material of the following museums and private collections have been studied:

AMNH American Museum of Natural History, U.S. New York (NY) (L. Herman)

BMNH British Museum, Natural History, Great Britain, London (R. Booth)

FMNH Field Museum of Natural History, U.S.A, Chicago (A. Newton, J. Boone)

IES Colletions of the Instituto de Ecologia $y$ Sistemática, Havanna, Cuba (A. Lozada Pinha)

INPA Instituto Nacional de Pesquisas da Amzónia, Manaus, Brazil

ISNB Institute de la science naturelle de Belgique, Belgium, Bruxelles (G. Yvonnick)

KNHM Kansas Natural History Museum, Snow Entomological collections, U.S.A. Kansas, Lawrence (J. S. Ashe, Z. Falin)

MCZ Museum of Comparative Zoology, U.S.A., Boston (P. Perkin)

MNHN Museum National d'Historie Naturelle, Paris, France (A. Taghavian)

MZLU Museum of Zoology of Lund University, Sweden, Lund (R. Danielsson)

NHMH National Museum of Natural History, Hungary, Budapest (G. Makranczy)

NHMP National Museum of Natural History, Cech Republic, Prague (M. Fikáček)

NHMW Naturhistorisches Museum Wien, Austria, Vienna (H. Schillhammer)

NMNH National Museum of Natural History, U.S.A. Washington (D. G. Furth)

SDEI Senkenberg, Deutsches Entomologisches Institut, Müncheberg, Germany, (S. Blank, L. Behne)

SMNH Swedish Museum of Natural History, Stockholm (R. Danielsson)
ZMHB

Zoologisches Museum of Humboldt University Berlin, Germany, Berlin (J. Frisch)

JMC Private collection of J. Márquez Luna, Hidalgo, Carboneras, Mexico

MSC Private collection of M. Schülke, Berlin, Germany

UIC Private collection of U. Irmler, Plön, Germany

VAC Private collection of V. Assing, Hannover, Germany

For the measurements of the total length, the intersegmental space of abdominal segments was considered. The lengths of individual tagmata were determined along the midline, their width at the widest part of the respective tagma

Numeration of protibial digits and length and width measures of the protibia can be derived from fig. 1 . Width: length ratio (WLR) of the second digit was used for the characterisation of the protibial digits.

For the photographs, a Makroskop M 420 (Wild Herbrugg) was used in combination with a digital camera (Leica EC3) and CombineZ5 (HADLEy 2006) for optimising the depth of focus.

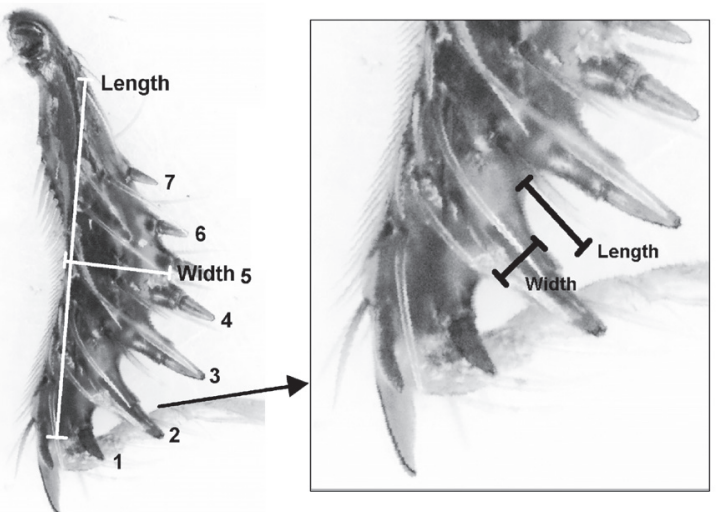

Fig. 1: Showing the measurement of length and width of the protibia and of the second protibial digit to determine the width: length ratio (WLR).

Results

Key to species groups

1 Very small species of $2.0-2.3 \mathrm{~mm}$ length, abdominal segement VII with long spines. O. coronatus group Species usually longer than $2.3 \mathrm{~mm}$, abdominal segment VII without spines.

2 Clypeal angles produced to long teeth-like spines or anterior edge of clypeus denticulate and protibia without apical digits; spines directely inserted on outer edge, pronotum with impunctate midline, shorter than $6.0 \mathrm{~mm}$.

Clypeal angles not produced to long spines; if anterior edge of clypeus denticulate or with teeth-like spines, then pronotum without impunctate midline or protibia with long apical digits; if clypeus with central emargination, then species at least $6.9 \mathrm{~mm}$ long.

3 Aedeagus asymmetric, right face of apical lobe sclerotised, left face soft, clypeal angles produced to long spines, spines of protibia not inserted on digits or digits extremely short (WLR: 2.4 - 5.7). O. bicornis group Aedeagus symmetric, both sides sclerotised, anterior edge of clypeus denticulate or produced angles of clypeus bidentate, apical protibial digits short (WLR: $1.0-3.8$ ). O. oculatus group 
4 Head, pronotum and elytra without setiferous punctation or setae extremely short; punctures fine or coarse; apical

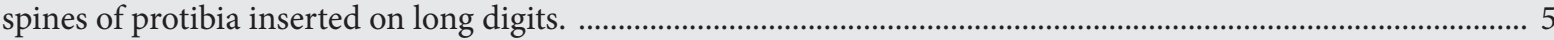

Head, pronotum and elytra with setiferous punctation. ….................................................................................. 7

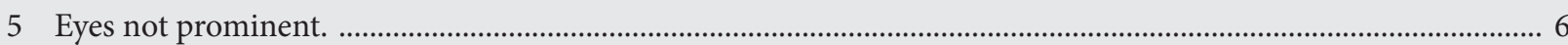

Eyes prominent, punctation of pronotum coarse and dense; pronotum without microsculpture or with weak microsculpture and micro-punctation; apical spines on long digits (WLR: $0.36-0.61$ ); last abdominal tergites often with elongate punctation.

O. guiananus group

6 Punctation of pronotum extremely fine and sparse, microsculpture of pronotum dense and surface matt, apical digits on protibia moderately long (WLR: 0.8 ).

O. laeviusculus group

Punctation of pronotum coarse; without microsculpture apical digits on protibia moderately long.

O. mrazi n. sp.

7 Pronotum and elytra densely pubescent, anterior edge of clypeus even or emarginate, antennomeres more or less equal in width, apical spines of slender protibia inserted on moderatly long digits (WLR: $0.4-1.6$ ), between $4.8 \mathrm{~mm}$ and $7.8 \mathrm{~mm}$ long. O. hirtulus group

Pronotum and elytra either with dense setiferous punctation and smaller or setiferous punctation distinctly sparser, interstices between punctures at least as wide as diameter of punctures.

8 Spines of protibia not inserted on digits or digits wider than long; WLR: higher than 1.0.

9 Only left face of apical aedeagal lobe sclerotised, mostly small species between 2.5 and 6.5 mm length, only few species longer. Osoriellus s. str. group

Aedeagus large and strongly sclerotised, large species, longer than $6.5 \mathrm{~mm}$.

O. granarius group

\section{Acknowledgement}

I thank the curators of the museums, institutions and private collectors for the steady support, help and relinquishment of several specimens for my collection. I also heartly thank Dr. Guillaume de Rougemont (London, Great Britain) for species from Ecuador, Dr. Michael v. Tschirnhaus (Bielefeld, Germany) for species from Venezuela, Tim Struyve (Mechelen, Belgium) for species from French Guiana, and Dr. Manfred Verhaagh (Karlsruhe, Germany) for species from Peru.

\section{Osoriellus-coronatus-group}

The species group is characterised by the specific structure of the VII abdominal segment that carries a row of long acute teeth on its posterior edge. The species are small.

\section{Description of species}

\section{Osoriellus coronatus n. sp.}

(Figs 2A - E, 5A)

Type material: Holotype, male: Brazil: Amazonas, Manaus, INPA/Smithsonian Res. 2 (59 $50^{\prime} \mathrm{W}, 2^{\circ} 25^{\prime} \mathrm{N}$ ), leaf litter, Terra firme forest, Winkler method, male, March 1994, leg. R. Didham, \#312 4 (BMNH).
Paratypes: female with same data as holotype, but Feb. 1994, \#125 2 (BMNH); female with same data as holotype, but May 1994, \#772 2 (BMNH); female with same data as holotype, but Jan. 1994, \#93 1 (BMNH, UIC); French Guyana: Saül $\left(53^{\circ} 12^{\prime} \mathrm{W}, 3^{\circ} 37^{\prime} \mathrm{N}\right)$, 1 male, 3 females 27.7.1981, leg. Perrault (UIC, MNHN).

Diagnosis: Currently only this species of the group can be described. It is distinctly characterised by the specific structure of the abdominal segment VII. However, similar specimens were found in Panama and Ecuador with the same spine structure at abdominal segement VII, which seem to be different species. Unfortunately, only female specimens from these countries are available that avoid a sufficient description. Nevertheless, it is supposed that more than one species can be expected in this group.

Description: Length: $2.1 \mathrm{~mm}$. Colouration: Dark yellow; head light brown; elytra yellow with black posterior edge; legs and antennae yellow.

Head: $0.22 \mathrm{~mm}$ long, $0.36 \mathrm{~mm}$ wide; eyes sligthly prominent; nearly as long as temples; sides in front of eyes narrowed to anterior edge in smooth concave curve; anterior edge of clypeus even; setiferous punctation coarse and dense; yellow setae of large punctures at least as long as double diameter of punctures; interstices between punctures less than half of diameter of punctures; surface of interstices and punctures with dense isodiameteric microsculpture; surface matt. 
Antennae nearly as long as head and half of pronotum combined; second antennomere oval and as thick as first antennomere; nearly twice as long as narrower third antennomere; following three antennomeres approximately quadrate and equal in width; antennomeres six to eleven increasing in width; antennomere six slightly wider than long; seven nearly twice as wide as long; antennomere ten thick and only slightly wider than long.

Pronotum: $0.32 \mathrm{~mm}$ long, $0.36 \mathrm{~mm}$ wide; widest at anterior angles; evenly narrowed in smooth curve to obtuse posterior angles; lateral margin very fine; in dorsal aspect not visible close to anterior angles; setiferous punctation sparser and less deep than on head; interstices between punctures at least as wide as diameter of punctures; yellow setae long; at least as long as double diameter of punctures; without microsculpture; surface polished and shiny.

Elytra: $0.42 \mathrm{~mm}$ long, $0.38 \mathrm{~mm}$ wide; widest in posterior third, but sides nearly parallel; setiferous punctation coarse and dense; setae pointing posteriad; ground sculpture deep; surface matt.

Abdomen with dense and deep setiferous punctation; punctures coarse and interstices less than half of diameter of punctures; without microsculpture; surface shiny; segment VII with three pairs of long spines; one dorsally in middle and two on each side.

Protibia: $0.19 \mathrm{~mm}$ long, $0.07 \mathrm{~mm}$ wide; with seven long spines at outer edge; apical spines inserted directly on outer edge; WLR: 3.0; in posterior aspect, comb at inner emargination covered in middle; posterior face with moderately dense long setation.

Aedagus stout and thick with nearly straight apical lobe; five sensillae at base of apical lobe.

Etymology: The specific name coronatus derived from the same Latin word meaning crowned and refers to the crown-like structure of abdominal segment VII.

\section{Osoriellus-laeviusculus-group}

This species group is characterised by the combination of the following characters: absence of setiferous punctation, absence of an impunctate midline on the pronotum, a characteristic longitudinal pronotal microsculpture, and the presence of digits on the apical outer edge of the protibia.

\section{Description of species}

Osoriellus laeviusculus (BERNHAUER, 1920) new
combination
(Figs 3A-B, 5B)

Osorius laeviusculus BernhaUer, 1920: 9

Type material examined: Brazil: Santa Catharina, female without further date, leg. Klimsch (holotype in FMNH).
Further material examined: Brazil: São Paulo, 2 females, without further data, leg. J. Mráz (NHMP).

Diagnosis: Concerning the absence of the setiferous punctation and the impunctate pronotal midline, the species is most related to O. schubarti. It can be differentiated from that species by the smaller size and the even anterior margin of the clypeus.

Description: Length: $4.8 \mathrm{~mm}$. Colouration: black, posterior edge of pronotum reddish, elytra dark brown, legs and antennae yellow.

Head: $0.55 \mathrm{~mm}$ long, $0.90 \mathrm{~mm}$ wide; front edge of the clypeus even; clypeal angles produced into short teeth; eyes large and prominent, nearly twice as long as temples; with several supraocular setae and a fine punctation; interstices between punctures on average as wide as or slightly wider than diameter of punctures; punctures without setae; with fine and dense transverse microsculpture; surface nearly dull.

Antennae with first antennomere as long as following three, second antennomere oval and as long as conical third one; antennomeres four to six more or less quadrate; the following 4 antennomeres much larger and wider than long.

Pronotum: $1.00 \mathrm{~mm}$ long, $1.00 \mathrm{~mm}$ wide; widest at anterior edge; anterior angles not prominent; sides slightly narrowed to posterior angles; nearly parallel in the anterior half; stronger narrowed shortly in front of the posterior angles: lateral margin extremely fine; punctation deeper than on head, but sparser; interstices between punctures on average twice as wide as diameter of punctures; a moderately wide midline impunctate; on central disc, on each side of the midline with circular depression; microsculpture longitudinal; surface slightly shiny, more shiny than surface of head.

Elytra: $1.10 \mathrm{~mm}$ long, $1.00 \mathrm{~mm}$ wide; with weak coriaceous ground-sculpture and fine and sparse punctation; punctures without setae; surface slightly shiny.

Abdomen finely and sparsely punctate; punctures with short yellow setae pointing to the middle; wide midline impunctate.

Protibia: $0.53 \mathrm{~mm}$ long, $0.13 \mathrm{~mm}$ wide; with 7 spines on outer edge; apical spine on moderately long digits; WLR: 0.70; in posterior aspect, comb at inner emargination visible throughout ist total length; on anterior face with row of five setae; posterior face sparsely covered with long yellow setae.

Aedeagus unknown.

\section{Osoriellus schubarti n. sp.}

(Figs $4 \mathrm{~A}-\mathrm{D}, 5 \mathrm{C}$ )

Type material: Holotype, male: Brazil: Est. Rio de Janeiro, Petropolis $\left(43^{\circ} 11^{\prime} \mathrm{W}, 22^{\circ} 30^{\prime} \mathrm{S}\right)$, Alto da Serra, male, 10.09.1961; leg. H. Schubart (INPA). 
Paratype: Petropolis, Meio da Serra, male, 15.8.1960, leg. H. Schubart (UIC).

Diagnosis: Together with O. laeviusculus, the species has a specific combination of characters. It has no setiferous punctation and the aedeagus is symmetric with both sides of apical lobe sclerotised. Concerning the lateral margin of the pronotum and the absent spines on the posterior face of the protibia the species must be placed to the genus Osoriellus. The species resembles O. laeviusculus in the absence of the setiferous punctation, but the punctation is finer and sparser and the anterior edge of the clypeus is crenate, whereas it is even in O. laeviusculus. Furthermore, the microsculpture of the pronotum in O. schubarti is netlike, but longitudinal in O. laeviusculus. A crenate anterior edge and a symmetric aedeagus are also found in the O.-oculatus-group, but these species have a setiferous punctation.

Description: Length: $5.2 \mathrm{~mm}$. Colouration: Black; posterior angles and suture of elytra reddish; legs and antennae red.

Head: $0.70 \mathrm{~mm}$ long, $1.10 \mathrm{~mm}$ wide; eyes slightly prominent and slightly longer than temples; sides of clypeus evenly convergent to front angles; crenate edge truncate with outer angles produced to short teeth; punctation fine and moderately sparse; on average, interstices between punctures as wide as or slightly wider than diameter of punctures; on supraocular space, punctures elongate or striate; few supraocular punctures with setae; two setiferous punctures on each side of middle on line between front edge and posterior edge of eyes; with dense longitudinal microsculpture; surface matt.

Antennae slightly longer than head; second antennomere oblong; conical third antennomere as long as second; following three antennomeres as wide as preceding antennomeres; more or less quadrate; antennomeres 7 to 11 thicker than preceding antennomeres, but also quadrate.

Pronotum: $1.06 \mathrm{~mm}$ long, $1.20 \mathrm{~mm}$ wide; widest at anterior angles; evenly convergent to widely rounded posterior angles; lateral margin fine; in dorsal aspect, visible throughout its total length; punctation fine and sparse; still finer and sparser than on head; distance between punctures at least two times wider than diameter of punctures; indistinct impunctate midline; few setiferous punctures along anterior and lateral margin

Key to the species

1 Longer than $5.0 \mathrm{~mm}$, anterior edge of clypeus crenate and pronotum with netlike microsculpture. O. schubarti n. sp.

Smaller than $5.0 \mathrm{~mm}$, anterior edge of clypeus even and pronotum with longitudinal microsculpture. O. laeviusculus (BERNHAUER, 1920) and two setiferous punctures on lateral third; netlike microsculpture distinct; less dense than on head; thus, surface slightly shiny.

Elytra: $1.28 \mathrm{~mm}$ long, $1.24 \mathrm{~mm}$ wide; with weak coriaceous ground sculpture; punctation fine and sparse, but punctures larger than on pronotum; surface shiny.

Abdomen with sparse and fine punctation; on segment VII with deeper and larger punctation than on preceding segments; without microsculpture; surface polished and shiny.

Protibia: $0.65 \mathrm{~mm}$ long, $0.17 \mathrm{~mm}$ wide; outer edge with 7 long spines; apical spines on moderately long digits; WLR: 0.83; in posterior aspect, comb at inner emargination visible throughout its total length; posterior face sparsely covered by long setae.

Aedeagus symmetric; with beak-like apical lobe ending in acute apex.

Etymology: The specific name derived from the collector of the species, Prof. H. Schubart.

\section{Osoriellus-oculatus-group}

This species group is mainly characterised by the symmetric structure of the aedeagus. In this respect they differ from the O.-s. str.-group. The species have a setiferous punctation, short or moderately long digits on the outer edge of the protibia and granulate or deeply emarginate anterior edge of the clypeus. The species are moderately long.

\section{Description of species}

\section{Osoriellus denticornis n. sp. \\ (Figs 10A-D, 11D)}

Type material: Holotype, male: British Guyana: Essequibo River, Moraballi Creek, male, 1929, leg. Oxford University Expedition, BM \#1929-485 (BMNH).

Diagnosis: Acording to the structure of the aedeagus and the placement of the lateral sensillae, O. denticornis is placed to the O.-oculatus-group, although strongly produced angles of the clypeus are also found in the O.-bicornis-group. However, in the O.-bicornis-group, the aedeagus is asymmetric with lateral opening. The species can be easily identified by the specific structure of the clypeus among all Neotropical Osoriellus species.

Description: Length: $3.4 \mathrm{~mm}$. Colouration: Dark brown; abdomen slightly lighter brown; legs and antennae yellow. Head: $0.54 \mathrm{~mm}$ long, $0.67 \mathrm{~mm}$ wide; eyes slightly prominent; fore-head narrowed to anterior angles of clypeus in concave curve; anterior angles of clypeus strongly produced to broad bidentate teeth; anterior edge of clypeus deeply emarginate between lateral teeth; outer 
edge of lateral teeth smoothly curved; inner edge straight; setiferous punctation dense and deep; on vertex denser than on clypeus; setae long and yellow; longer than two times of diameter of punctures; interstices between punctures on vertex shorter than diameter of punctures; small area on vertex and at base of antennae impunctate; without microsculpture; surface shiny.

Antennae as long as head and quarter of pronotum combined; second antennomere oblong and distinctly longer than conical third; following three antennomeres not wider than third, but shorter; fourth approximately quadrate; sixth wider than long; following antennomeres distinctly wider than preceding antennomeres; approximately quadrate.

Pronotum: $0.57 \mathrm{~mm}$ long, $0.69 \mathrm{~mm}$ wide; widest at anterior angles; narrowed in smoothly even curve to obtuse posterior angles; lateral margin fine; in dorsal aspect, not visible in anterior quarter; setiferous punctation coarse and dense; yellow setae long; longer than three times of diameter of punctures; on average, interstices between punctures as wide as diameter of punctures; wide midline impunctate; without microsculpture; surface shiny.

Elytra: 0.72 long, $0.68 \mathrm{~mm}$ wide; sides nearly parallel; shoulders obtusely rounded; setiferous punctation coarse and dense; yellow setae as long as on pronotum; interstices between punctures less wide than diameter of punctures; coriaceous ground sculpture weak.

Abdomen densely and deeply punctate; yellow setae as long as on fore-body; without microsculpture; surface shiny.

Protibia: $0.38 \mathrm{~mm}$ long, $0.13 \mathrm{~mm}$ wide; 7 long spines at outer edge; apical spines inserted on moderately long digits; WLR: 1.1; in posterior aspect, comb at innern emargination visible throughout its total length; posterior face with moderately dense, long yellow setation.

Aedeagus stout; symmetric; apical lobe thick and sinuate at upper edge; only slightly longer than width of basal lobe; three sensillae on lateral face of apical lobe.

Etymology: The specific name is a combination of the Latin word dens meaning tooth and cornis meaning horn and refers to the structure of the clypeal angles.

Osoriellus hanagarthi $\mathrm{n}$. sp.

(Figs 8A-D, 11A)

Type material: Holotype, male: Peru: Huanuco, Panguana (7456'W, 9³7'S), Cocha, male, 6.-9.1975, leg. W. Hanagarth (UIC).

Paratypes: from the same location, 4 females, June - Sept. 1975, Oct. 75 - Jan. 1976, leg. W. Hanagarth; river margin, female, 26.12.1975, leg. W. Hanagarth (UIC); Madre de Dios, Iberia, 160 m elevation, female, 30.4.1947, leg. J.C. Pallister; Huanuco, Tingo Maria, $670 \mathrm{~m}$ elevation, male, 29.12.1946, leg. J.C. Pallister (AMNH); Madre de Dios, Puerto Maldonado, 1 female, 6.1.1984, leg. L. Huggert (SMNH); Venezuela: Aragua,
Rancho Grande Biological Station, $28 \mathrm{~km} \mathrm{~N}\left(67^{\circ} 41.0^{\prime} \mathrm{W}\right.$, $\left.10^{\circ} 28.0^{\prime} \mathrm{N}\right), \mathrm{km} 48,120 \mathrm{~m}$ elevation, male, collected by flight intercept trap VEN1P94, 22.6.-18.7.1994, leg. T. Phillips (KNHM).

Diagnosis: The species resembles O. ocularis and O. oculatus in the crenate structure of the clypeus. In contrast to these two species, the eyes of O. hanagarth $i$ are shorter and not produced. Moreover, the apical lobe of the aedeagus is shortly rounded at apex and much short than in the two other species.

Description: Length: $4.0-4.2 \mathrm{~mm}$. Colouration: Black, legs and antennae yellow.

Head: $0.50 \mathrm{~mm}$ long, $0.80 \mathrm{~mm}$ wide; eyes approximately as long as temples, not prominent; sides of fore-head evenly convergent to anterior angles; anterior edge crenate with slightly produced teeth at angles; setiferous punctures deep and large; setae pointing to middle; punctation dense on supraocular area nearly coriaceous; interstices between punctures not wider than one fourth as wide as diameter of punctures; wide midline and area at base of antennae impunctate; without microsculpture; surface polished and shiny.

Antennae with first antennomere more or less as long as following two antennomeres; second antennomere oval; conical third antennomere slightly shorter than second; following three antennomeres not wider than second and quadrate; antennomeres 7 to 11 much thicker than preceding antennomeres; antennomere 10 slightly wider than long.

Pronotum: $0.75 \mathrm{~mm}$ long, $0.80 \mathrm{~mm}$ wide; widest at anterior angles; evenly convergent to posterior angles; slightly emarginate in posterior half; posterior angles obtuse; lateral margin very fine; in dorsal aspect, not visible in anterior half; setiferous punctation irregular; punctures slightly larger and deeper than on head; on both sides of impunctate midline with row of 12 punctures; dense punctation between midline and lateral margin, but few areas with sparser punctation; without microsculpture, but with sparse micro-punctation; surface polished.

Elytra: $0.95 \mathrm{~mm}$ long, $0.80 \mathrm{~mm}$ wide; with deep coriaceous ground-sculpture; setiferous punctures in rows; nearly invisible in coarse ground-sculpture.

Abdomen deeply and densely punctate; setae short, pointing to middle; with impunctate and shiny midline.

Protibia $0.50 \mathrm{~mm}$ long, $0.15 \mathrm{~mm}$; outer edge with 9 spines; apical spines on short digits; WLR: 2.7; inner edge nearly straight; in posterior aspect, comb at inner emargination visible throughout its total length; posterior face covered by thick setae.

Aedeagus thick with obtuse apex; few sensillae at inner edge of apical lobe.

Etymology: The species is named to its collector and my dear friend Dr. Werner Hanagarth, who unfortunately passed too early. 


\section{Osoriellus ocularis $\mathrm{n}$. $\mathrm{sp}$.}

(Figs 6A-D, 11B)

Type material: Holotype, male: Brazil: Pará, Jacareacanga $\left(57^{\circ} 45.38^{\prime} \mathrm{W}, 6^{\circ} 13.24 \mathrm{~S}\right)$, X.1959, leg. M. Alvarenga (INPA).

Paratypes: Brazil: 1 male, 7 females with same data as holotype (INPA, UIC); French Guiana: Nason; Marowijne River, Wanaboo $\left(54^{\circ} 26^{\prime} 36^{\prime \prime} \mathrm{W}, 4^{\circ} 43^{\prime} 35^{\prime \prime} \mathrm{N}\right)$, flight intercept trap, male, 5.6.1999, leg. Z.H. Falin (KNHM); Bolivia: Beni, Ilha Flores $\left(63^{\circ} 07^{\prime} \mathrm{W}, 12^{\circ} 46^{\prime} \mathrm{S}\right)$, Rio Iténez, 9 females, 9 males, 7.8.1964, leg. J.K. Bouseman \& L. Lussenhop (AMNH, UIC); Beni, Capivara, $30 \mathrm{~km}$ E Versales $\left(63^{\circ} 16^{\prime} \mathrm{W}, 12^{\circ} 43^{\prime} \mathrm{S}\right)$, female, 22.7.1964, leg. J.K. Bouseman \& L. Lussenhop (AMNH); Beni, Guayaramerin, Fundo Nuevo Cuba, Soil Zoological Expedition, NO.408, netted from vegetation, 2 females, 22. + 26.11.1966, leg. J. Balogh, L.S. Mahunka, Zicsi (NMB).

Diagnosis: Among the species with a crenate front edge of the clypeus, i.e. O. oculatus and O. hanagarthi, the species can identified by its small size in combination with large, prominent eyes. In dorsal aspect, the space between eyes is only 6 times as wide as the diameter of eyes. The teeth at clypeal angles are longer than in O. oculatus and $O$. hanagarthi. Furthermore, the apical lobe of the aedeagus is longer than in the two other species.

Description: Length: 3.7 - $3.8 \mathrm{~mm}$. Colouration: Head and pronotum dark brown, abdomen, elytra, legs, and antennae light red; elytra at posterior margin indistinctly darker.

Head: $0.65 \mathrm{~mm}$ long, $0.80 \mathrm{~mm}$ wide; eyes large and prominent; in dorsal aspect, space between eyes 6 times as wide as diameter of eyes; sides of fore-head convergent to front edge of clypeus in even concave curve; front margin of clypeus crenate and with larger teeth at angles; on large supraocular area with dense and coarse setiferous punctation; clypeus with distinctly finer and sparser setiferous punctation, setae yellow and pointing to apical centre; wide area on vertex impunctate and surface polished and shiny; on remaining vertex and on clypeus with distinct netlike microsculpture; surface matt except small shiny area at base of antennae.

Antennae with first antennomere as long as three following ones, second antennomere oval and longer than conical third antennomere; antennomeres four to six more or less quadrate and not wider than preceding antennomeres; following antennomeres distinctly thicker.

Pronotum: $0.67 \mathrm{~mm}$ long, $0.75 \mathrm{~mm}$ wide; widest at anterior margin; evenly convergent to posterior margin; at posterior angles only two-third as wide as at anterior angles; in dorsal aspect, lateral margin fine; visible in its total length; setiferous punctation coarse and deep; interstices between punctures only one-fourth of diameter of punctures; yellow setae pointing to middle; punctures close to impunctate midline in indistinct rows of up to
9 punctures; without microsculpture, but with sparse micro-punctation; surface shiny.

Elytra: $0.90 \mathrm{~mm}$ long, $0.80 \mathrm{~mm}$ wide; with coriaceous ground-sculpture; surface less shiny than pronotum; setiferous punctation as coarse and deep as on pronotum; yellow setae pointing distad.

Abdomen densely and deeply punctate; yellow setae pointing distad.

Protibia $0.50 \mathrm{~mm}$ long, $0.13 \mathrm{~mm}$ wide; moderately thick and with 9 long spines at outer edge; apical spines inserted on short digits; WLR: 3.8; in posterior aspect, inner edge nearly straight and comb covered in middle; posterior face densely covered by long yellow setae.

Aedaegus with long apical lobe; apical lobe even longer than basal lobe and widely rounded at obtuse apex; only two sensillae at lateral inner edge of apex.

Etymology: The specific name derived from the Latin word oculus meaning eye and refers to the large eyes.

\section{Osoriellus oculatus (SHARP, 1876) new combination (Figs 7A-D, 11C)}

\section{Osorius oculatus SHARP, 1876: 386}

Type material examined: Brazil: Tefé $\left(64^{\circ} 41^{\prime} \mathrm{W}, 3^{\circ} 21^{\prime} \mathrm{S}\right)$, without further data (holotype BMNH).

Further material examined: Brazil: Mato Grosso, Cáceres $\left(54^{\circ} 42^{\prime} \mathrm{W}, 16^{\circ} 03^{\prime} \mathrm{S}\right), 3$ females, 7 males, 2./4.12.1955, leg. M. Alvarenga (UIC).

Diagnosis: Within the O.-oculatus-group, the species is characterised by its prominent eyes and the 3 short teeth on each side of the middle at anterior edge of the clypeus. The punctation of the pronotum is similar as in O. hanagarthi, but the shape of the pronotum is different. In O. oculatus, the pronotum is more deeply sinuated shortly in front of the posterior angles than in O. hanagarthi. The aedeagi are very similar in $O$. oculatus and $O$. hanagarthi, but the apex of the aedeagus in O. hanagarthi is obtuse, whereas it is acute $O$. oculatus.

Description: Length: $4.2-4.7 \mathrm{~mm}$. Colouration: Dark brown; legs and antennae reddish.

Head: $0.60 \mathrm{~mm}$ long, $0.85 \mathrm{~mm}$ wide: with large and prominent eyes; eyes at least half as long as temples; angles of clypeus produced to short teeth; adjacent to tooth two smaller granules; middle not granulate, but slightly produced; clypeus and disc densely and coarsely punctate; interstices between punctures almost one-fourth as wide as diameter of punctures; large supraocular and indifferent area on vertex impunctate; surface moderately shiny; on parts of vertex indistinct weak microsculpture present.

Antennae with oblong second antennomere; third antennomere conical; one-fourth shorter than second; 
antennomeres 4 to 6 quadrate and equal in width; antennomeres 7 to 11 much wider and longer than preceding ones, slightly wider than long.

Pronotum: $0.80 \mathrm{~mm}$ long, $0.85 \mathrm{~mm}$ wide; widest at anterior angles, in anterior two-third slightly narrowed; in posterior third more strongly convergent to posterior angles; posterior angles obtusely rounded; lateral margin fine; in dorsal aspect, not visible at anterior angles; surface with large and deep setiferous punctures; interstices between punctures approximately half as wide as diameter of punctures; at each side of wide impunctate midline with row of 10 to 11 punctures partly forming coriaceous furrow; without microsculpture, but with sparse micro-punctation; surface shiny.

Elytra: $1.0 \mathrm{~mm}$ long, $0.90 \mathrm{~mm}$ wide; with dense, partly coriaceous setiferous punctures; punctures forming irregular rows; punctation laterally sparser than on disc; surface shiny, but partly with weak coriaceous groundsculpture.

Abdomen with dense setiferous punctation; setae pointing to middle; interstices between punctures less than one-fourth of diameter of punctures.

Protibia $0.48 \mathrm{~mm}$ long, $0.17 \mathrm{~mm}$ wide; with 9 spines at outer edge; apical spines inserted on short digits; WLR: 2.1; in posterior aspect, comb at inner emargination visible, but partly covered in apical part; on posterior face with dense setation.

Aedeagus stout with short apical lobe and four sensillae at inner edge.

\section{Osoriellus sexdentatus n. sp.}

(Figs 9A-D, 11E)

Type material: Holotype, male: French Guiana: Wanaboo (near Nason) Marowijne River, $40 \mathrm{~m}$ elevation $\left(54^{\circ} 26.36^{\prime} \mathrm{W}, 4^{\circ} 43.35^{\prime} \mathrm{N}\right)$, ex flight intercept trap, 31.5.5.6.1999, leg. Z.H. Falin \& B. DeDijn, SUR1F99 032 (KNHM).

Diagnosis: The species resembles O. ocularis and O. oculatus by its large prominent eyes. The eyes are similarly large as in O. oculatus and, therefore, slightly smaller than in O. ocularis. The front edge of the clypeus is similar as in O.ocularis, but with only four teeth between the larger outer teeth and not with six teeth as in O. ocularis.

Description: Length: $4.0 \mathrm{~mm}$. Colouration: Black; elytra and abdomen brown; legs and antennae light brown.

Head: $0.63 \mathrm{~mm}$ long, $0.79 \mathrm{~mm}$ wide; eyes prominent; longer than temples; sides of fore-head evenly convergent; angles of clypeus produced to long teeth and four smaller teeth on anterior edge; punctation dense and coarse and with impunctate midline on vertex; clypeus with isodiametric microsculpture; surface slightly shiny; vertex without microsculpture; surface polished and shiny; several setiferous punctures at upper margin of eyes; two setiferous punctures on vertex and several setiferous punctures on clypeus.

Antennae slightly longer than head; with second antennomere oblong and thicker than conical third antennomere; following 3 antennomeres as wide as third, but quadrate; antennomeres 7 to 11 distinctly thicker than preceding antennomeres; more or less quadrate.

Pronotum: $0.76 \mathrm{~mm}, 0.81 \mathrm{~mm}$ wide; widest at anterior angles; slightly narrowed in anterior two-third; in posterior third abruptly more strongly narrowed; setiferous punctation large and in irregular rows; within row interstices between punctures only half as wide as diameter of punctures; between rows interstices as wide as diameter of punctures; without microsculpture, but with sparse micro-punctation; surface polished and shiny.

Key to the species

1. Eyes large and distinctly prominent, temples shorter than eyes.

Eyes not or slightly prominent, as long as temples.

2. Front edge of clypeus with 8 teeth between tooth-like angles. O. hanagarthi n. sp.

Front angles of clypeus produced to long bidentate teeth. O. denticornis n. sp

3. Between 4.2 and $4.7 \mathrm{~mm}$ long, anterior edge of clypeus with 3 short lateral teeth and even slightly prominent middle. O. oculatus (SHARP, 1876)

Between 3.7 and $4.0 \mathrm{~mm}$ long, anterior edge of clypeus with more than 3 teeth.

4. Clypeus with 6 short teeth between long teeth at angles. O. ocularis n. sp.

Clypeus with 4 short teeth between long teeth at angles. O. sexdentatus $\mathrm{n}$. $\mathrm{sp}$.

Elytra: $0.96 \mathrm{~mm}$ long, $0.87 \mathrm{~mm}$ wide; with coriaceous ground-sculpture and weak setiferous punctation; interstices between punctures at least as wide as diameter of punctures.

Abdomen densely punctate; with large setiferous punctures; yellow setae pointing posteriad; without impunctate midline.

Protibia: $0.50 \mathrm{~mm}$ long, $0.13 \mathrm{~mm}$ wide; with 8 spines at outer edge; apical spines inserted on moderately long digits; WLR: 1.0; in posterior aspect, comb at inner emargination visible throughout its total length; posterior face densely covered by long yellow setae.

Aedeagus with triangular apical lobe and several sensillae at inner edge.

Etymology: The specific name refers to the 6 teeth at the anterior edge of the clypeus. 


\section{Osoriellus-bicornis-group}

The species of this group resembles those of the O.-s. str.group in size, the presence of a setiferous punctation, the asymmetric aedeagus, and the absence of digits on the outer edge of the protibia. In contrast to those species, they have strongly produced angles of the clypeus.

\section{Description of species}

\section{Osoriellus bicornis $\mathrm{n} . \mathrm{sp}$.}

(Figs. 14A-D, 20A)

Type material: Holotype, male: Peru: Tambopata Prov., Madre de Dios Dpto., $15 \mathrm{~km}$ NE Puerto Maldonado, Reserva Cuzco Amazónico (12³3'S, 6903'W), $200 \mathrm{~m}$ elevation, Z2 E15, flight intercept trap, 26.6.1989, leg. D. Silva \& R.A. Leschen, \#285 (KNHM).

Diagnosis: The species can be easily identified by the produced truncate teeth of the clypeus. The other species with teeth-like produced angles of the clypeus are longer than $4 \mathrm{~mm}$ and teeth are acute.

Description: Length: $3.7 \mathrm{~mm}$. Colouration: Light brown, except fore-head; posterior head darker brown; legs and antennae yellow.

Head: $0.56 \mathrm{~mm}$ long, $0.71 \mathrm{~mm}$ wide; eyes distinctly prominent; as long as temples; sides of fore-head narrowed to front edge in concave curve; anterior angles of clypeus produced to broad truncate teeth; teeth longer than onefourth of distance between them; setiferous punctation irregularly dense and deep; on vertex denser than on forehead; wide midline, area at base of antennae and transverse area on posterior vertex impunctate; on average on punctate areas, interstices between punctures distinctly shorter than diameter of punctures; with remains of weak microsculpture; surface slightly shiny.

Antennae as long as head and half of pronotum combined; second antennomere oblong; wider and nearly twice as long as conical third antennomere; following antennomeres increasing in width; fourth quadrate; fifth and sixth wider than long; sixth antennomere twice as wide as long; antennomeres 7 to 10 distinctly wider than preceding antennomeres and quadrate.

Pronotum: $0.67 \mathrm{~mm}$ long, $0.71 \mathrm{~mm}$ wide; widest at anterior angles; anterior angles shortly produced to acute teeth; sides evenly convergent to smoothly rounded posterior angles; in anterior half less narrowed than in posterior half; lateral margin fine; in posterior half slightly wider; in dorsal aspect, not visible close to anterior angles; setiferous punctation deep and sparser than on vertex of head; in irregular longitudinal rows; midline impunctate; on average, interstices between punctures of rows as wide as diameter of punctures; interstices between punctures wider than diameter of punctures; microsculpture deep, but not dense; surface slightly shiny.
Elytra: $0.87 \mathrm{~mm}$ long, $0.75 \mathrm{~mm}$ wide; setiferous punctation distinct; in rows; coriaceous ground-sculpture weak; surface less shiny than on pronotum and head. Abdomen with dense setiferous punctation; without impunctate midline; interstices between punctures with weak netlike microsculpture; surface shiny.

Protibia: $0.39 \mathrm{~mm}$ long, $0.11 \mathrm{~mm}$ wide; with 8 spines at outer edge; apical spines not inserted on digits; WLR: 3.5; in posterior aspect, comb at inner emargination nearly invisible in central part, but with very long setae at base; posterior face sparsely covered by yellow setae.

Aedeagus with smoothly curved apical lobe ending in obtuse apex; inner edge of apical lobe with row of sensillae in regular distances.

Etymology: The specific name derived from the Latin word meaning two horns and refers to the two horn-like truncate teeth of the clypeus.

\section{Osoriellus bovis $\mathrm{n} . \mathrm{sp}$.}

(Figs 12A-D, 20C)

Type material: Holotype, male: French Guyana: Roura, $8.4 \mathrm{~km} \mathrm{SSE}\left(52^{\circ} 13.0^{\prime} \mathrm{W}, 4^{\circ} 40.0^{\prime} \mathrm{N}\right), 200 \mathrm{~m}$ elevation, flight intercept trap, 29.05.-10.06.1997, leg. J.S. Ashe, R. Brooks, \#FG1AB97 182 (KNHM).

Paratypes: French Guyana: 1 male with same dates as holotype; 1 female, Matoury, $41.5 \mathrm{~km}$ SSW on Hwy N2 $\left(52^{\circ} 22.35^{\prime} \mathrm{W}, 4^{\circ} 37.22^{\prime} \mathrm{N}\right), 50 \mathrm{~m}$ elevation, flight intercept trap, 26.-28.05.1997, leg. J. Ashe, R. Brooks, \#FG1AB97 060 (KNHM, UIC); Guyana: Essequibo River, Moraballi Creek, female, 1929, Oxford University Expedition (BMNH).

Diagnosis: As O.notmani and O.cornutus, O. bovis carries a pair of long lateral teeth on the clypeus. It is smaller than these two species, in particular, compared to O. notmani with $5.9 \mathrm{~mm}$ length. Furthermore, in contrast to O. notmani, O. bovis has no digitate protibia as the other species of the O.-bicornis-group, whereas $O$. notmani has long apical digits on outer edge of the protibia and is, therefore, placed to the remainingspecies-group. O. bovis can be identified by the long yellow setae of the head and pronotum and the large, distinctly prominent eyes.

Description: Length: $4.5 \mathrm{~mm}$. Colouration: Dark brown; elytra lighter brown; legs and antennae reddish.

Head: $0.49 \mathrm{~mm}$ long, $0.85 \mathrm{~mm}$ wide; large eyes distinctly prominent; temples one-fourth as long as eyes; sides of fore-head deeply concave; sides of clypeus parallel; lateral angles of clypeus produced to long acute teeth; teeth longer than one-fourth of width between them; setiferous punctation fine and irregularly dense; on vertex, interstices between punctures as wide as diameter of punctures; long yellow setae pointing anteriad; wide 
midline impunctate; coriaceous microsculpture dense and deep; surface matt.

Antennae as long as head and half of pronotum combined; second antennomere thick and oval; third antennomere narrower than second, but conical; antennomeres 4 to 6 as wide as third, but quadrate; antennomeres 7 to 10 wider than preceding antennomeres and quadrate.

Pronotum: $0.82 \mathrm{~mm}$ long, $0.87 \mathrm{~mm}$ wide; widest at shortly produced anterior angles; anterior angles acute; sides evenly convergent to posterior angles; posterior angles rounded; lateral margin fine; in dorsal aspect, invisible in anterior third; setiferous punctation large and dense; interstices between punctures one-fourth as wide as diameter of punctures; wide midline impunctate; long yellow setae pointing anteriad; longitudinal microsculpture weak; surface shiny.

Elytra: $1.01 \mathrm{~mm}$ long, $0.91 \mathrm{~mm}$ wide, with coriaceous ground-sculpture; setiferous punctation in longitudinal rows; finer than on pronotum; surface less shiny than that of pronotum.

Abdomen densely punctate; on tergites V to VII narrow midline without setiferous punctures.

Protibia: $0.54 \mathrm{~mm}$ long, $0.17 \mathrm{~mm}$ wide; at outer edge with 10 long spines; apical spines not inserted on digits; WLR: 5.7; in posterior aspect, comb of inner emargination partly covered in middle; posterior face densely covered by long yellow setae.

Aedeagus angulate in nearly rectangular angle; apical lobe long; obtuse at apex; inner edge of apical lobe with 7 sensillae; another group of five sensillae at base of apical lobe.

Etymology: The specific name derived from the same Latin word meaning cow and refers to the pair of acute teeth of the clypeus.

\section{Osoriellus corniculatus n. sp.}

(Figs 18A-D, 20H)

Type material: Holotype, male: Colombia: Putumayo, Villagarzon, 6.IX.1984, leg. M. Cooper (BMNH).

Diagnosis: O. corniculatus is characterised by the specific structure of the clypeus. The clypeus is widely emarginate in the middle with shortly produced acute teeth in the angles. In the other species of the group, the space between the produced clypeal angles is either even or denticulate.

Description: Length: $5.2 \mathrm{~mm}$. Colouration: black, legs and antennae light brown.

Head: $0.81 \mathrm{~mm}$ long, $1.07 \mathrm{~mm}$ wide; eyes not prominent; approximately as long as temples; sides in front of eyes deeply emarginate; sides of clypeus parallel; anterior angles of clypeus produced to broad prominence; prominences half as wide as emarginate space between them; outer angles of prominences produced to long acute teeth; setiferous punctation sparse on fore-head; much denser on vertex; wide midline and large area at base of antennae impunctate; on vertex, interstices approximately half as wide as diameter of punctures; on fore-head, interstices at least as wide as diameter of punctures; narrow netlike microsculpture distinct; surface slightly shiny.

Antennae slightly longer than head; second antennomere oblong; slightly longer than conical third; following antennomeres increasing in width; antennomeres four to ten approximately quadrate.

Pronotum: $1.02 \mathrm{~mm}$ long, $1.10 \mathrm{~mm}$ wide; widest at anterior angles; anterior angles approximately rectangular; sides slightly and evenly convergent to obtusely rounded posterior angles; lateral margin fine; in anterior half finer than in posterior half; in dorsal aspect, nearly invisible at anterior angles; setiferous punctation coarse and dense; row adjacent to impunctate midline with more than 10 punctures and interstices between punctures of row shorter than half of diameter of punctures; on disc, punctation moderately dense; interstices between punctures as wide as and half as wide as diameter of punctures; netlike microsculpture distinct; surface slightly shiny.

Elytra: $1.31 \mathrm{~mm}$ long, $1.16 \mathrm{~mm}$ wide; with coriaceous ground-sculpture; setiferous punctures in irregular rows; punctures nearly invisible in coarse ground-sculpture.

Abdomen with dense setiferous punctation; on tergites, narrow midline impunctate; with remains of irregular microsculpture; surface between punctures shinier than on fore-body.

Protibia: $0.65 \mathrm{~mm}$ long, $0.22 \mathrm{~mm}$ wide; with 7 spines at outer edge; apical spines inserted on short digits; WLR: 2.4; in posterior aspect, comb at inner emargination visible throughout its total length; posterior face sparsely covered by long yellow setae.

Aedeagus rectangularly angulate; apical lobe slender; inner edge of apical lobe with numerous sensillae.

Etymology: The specific name derives from the Latin word cornus meaning horn and refers to the structure of the anterior angles of the clypeus.

\section{Osoriellus cornutus n. sp.}

(Figs 13A-D, 20D)

Type material: Holotype, male: Panama: Cana Biological Station, Serrania de Pirre $\left(77^{\circ} 41.06^{\prime} \mathrm{W}, 7^{\circ} 45.18^{\prime} \mathrm{N}\right)$, $1200 \mathrm{~m}$ elevation, flight intercept trap, 4.-7.6.1996, leg. J. Ashe, R. Brooks, \#PAN1AB96 105 (KNHM).

Diagnosis: The species resembles O. bovis and O. notmani concerning the pair of acute teeth of the clypeus. It can be differentiated from $O$. notmani by the smaller size and from $O$. bovis by the matt surface of the pronotum.

Description: Length: $4.8 \mathrm{~mm}$. Colouration: Black; lateral and posterior margin of pronotum, legs and antennae light brown. 
Head: $0.76 \mathrm{~mm}$ long, $1.01 \mathrm{~mm}$ wide; eyes slightly prominent; as long as temples; sides of fore-head concave; sides of clypeus parallel; lateral angles of clypeus produced to acute triangular teeth; teeth longer than one-fourth of width between them; setiferous punctation fine and sparse; wide midline impunctate; interstices between punctures more than twice as wide as diameter of punctures; on supraocular area punctation denser; interstices between punctures as wide as diameter of punctures; isodiametric microsculpture deep and dense; surface matt.

Antennae slightly longer than head; second antennomere oval and slightly wider than conical third; antennomeres 4 to 6 as wide as third antennomere, but quadrate; antennomeres 7 to 10 wider than preceding antennomeres and also quadrate.

Pronotum: $0.99 \mathrm{~mm}$ long, $1.02 \mathrm{~mm}$ wide; widest at anterior angles; evenly narrowed to widely rounded posterior angles; lateral margin fine; in posterior half slightly wider than in anterior half; in dorsal aspect, invisible close to anterior angles; setiferous punctation deep and dense; short yellow setae pointing posteriad; wide midline impunctate; punctures in irregular rows; interstices between punctures of row as wide as diameter of punctures; interstices between rows 1.5 times as wide as diameter of punctures; isodiametric microsculpture deep and dense; surface matt.

Elytra: $1.24 \mathrm{~mm}$ long, $1.15 \mathrm{~mm}$ wide; with deep coriaceous ground-sculpture; setiferous punctation in irregular rows; punctures nearly invisible in coarse ground-sculpture.

Abdomen with fine setiferous punctation except on narrow impunctate midline; surface between punctures polished and shiny.

Protibia: $0.55 \mathrm{~mm}$ long, $0.17 \mathrm{~mm}$ wide; with 8 spines on outer edge; apical spines on short digits; WLR: 2.7; posterior face sparsely covered by long yellow setae; in posterior aspect, comb covered in central part.

Aedeagus with apical lobe evenly curved to obtuse apex; inner edge of apical lobe with nine sensillae.

Etymology: The specific name derives from the same Latin word meaning horned and refers to the pair of long acute teeth of the clypeus.

\section{Osoriellus sinuatoangularis $\mathrm{n} . \mathrm{sp}$.} (Figs 16A-C, 20F)

Type material: Holotype, male: Peru: Tambopata Prov., Madre de Dios Depto., $15 \mathrm{~km}$ NE Puerto Maldonado, Reserva Cuzco Amazónico ( $\left.12^{\circ} 33^{\prime} \mathrm{S}, 6^{\circ} 03^{\prime} \mathrm{W}\right), 200$ m elevation, Plot \#Z2E15, 28.6.1989, leg. J.S. Ashe, R.A. Leschen, D. Silva, ex. flight intercept trap, \#310 (KNHM).

Paratype: female, with same data as holotype (UIC); Madre de Dios, Cuzco Amazonica $\left(69^{\circ} 2.6^{\prime} \mathrm{W}, 12^{\circ} 36.48^{\prime} \mathrm{S}\right)$, 300 m elevation, secondary forest W2, female, 17.5.1995, leg. D. Agosti (AMNH).
Diagnosis: The species can be identified by the short emargination at the posterior pronotal angles. At this pronotal part, the lateral margin ends without direct continuation to the posterior edge and, thus, forms a short emargination. In this respect it resembles O. subsinuatus. But O. subsinuatus has a distinct netlike pronotal microsculpture and matt surface, whereas the pronotum in O. sinuatoangularis has a weak microsculpture and shiny surface.

Description: Length: $4.5 \mathrm{~mm}$. Colouration: Brown; elytra and abdomen lighter reddish brown; legs and antennae red.

Head: $0.62 \mathrm{~mm}$ long, $0.92 \mathrm{~mm}$ wide; eyes slightly prominent and slightly longer than temples; sides of fore-head narrowed to anterior angels in deep concave curve; sides of clypeus parallel; anterior angles of clypeus produced to acute long teeth; between lateral teeth front edge even; setiferous punctation irregularly dense; on fore-head sparser than on posterior head; wide midline and large area at base of antennae impunctate; on vertex, interstices between punctures as wide as diameter of punctures; microsculpture moderately deep and dense; surface slightly shiny.

Antennae slightly longer than head; second antennomere oval and slightly longer than conical third antennomere; antennomeres 4 to 6 as wide as preceding antennomeres and quadrate; antennomeres 7 to 10 distinctly wider than preceding antennomeres and also quadrate.

Pronotum: $0.92 \mathrm{~mm}$ long, $0.95 \mathrm{~mm}$ wide; widest at smoothly rounded anterior angles; slightly convergent from anterior to posterior angles; shortly in front of posterior angles slightly stronger narrowed; lateral margin fine; in dorsal aspect, visible except a short part near anterior angles; lateral margin ending in front of posterior angles; posterior angles shortly emarginate and without margin; setiferous punctation large; in irregular rows; wide midline impunctate; within rows, interstices between punctures slightly shorter than diameter of punctures; between rows, interstices between punctures slightly wider; between coarse punctures with dense micro-punctation; microsculpture weaker than on head; surface shiny.

Elytra: $1.08 \mathrm{~mm}$ long, $0.96 \mathrm{~mm}$ wide; weak coriaceous ground sculpture; setiferous punctation sparser than on pronotum and in irregular rows.

Abdomen with dense setiferous punctation and wide impunctate midline; netlike microsculpture weak; surface shiny.

Protibia: $0.50 \mathrm{~mm}$ long, $0.20 \mathrm{~mm}$ wide; 9 spines on outer edge; apical spines not inserted on digits; WLR: 4.2; in posterior aspect, comb at inner emargination covered in central part; posterior face with dense setation.

Aedeagus with long apical lobe strongly curved to obtuse apex; laterally, at base of apical lobe with group of several sensillae. 
Etymology: The specific name is a combination of the epithet sinuatus meaning emarginate and angularis meaning angle and refers to the shortly emargination at the posterior angles of the pronotum.

\section{Osoriellus sinuatus $\mathrm{n}$. sp.}

(Figs 19A-C, 20E)

Type material: Holotype, male: Ecuador: Napo Prov. Sacha Lodge $\left(76^{\circ} 27.32 \mathrm{~W}, 0^{\circ} 28.15^{\prime} \mathrm{S}\right), 250 \mathrm{~mm}$ elevation, 26.-28.10.2004, leg. G. de Rougemont (UIC).

Paratypes: Ecuador: 1 male with same data as for holotype (UIC); Sucumbios Prov. Sacha Lodge $\left(76^{\circ} 5^{\prime} \mathrm{W}, 0^{\circ} 5^{\prime} \mathrm{S}\right)$, $270 \mathrm{~m}$ elevation, collected by Malaise trap, 4 females, 2 males, 13.-25.7.1994, 25.7.-3.8.1994, 3.-16.8.1994, 3.-13.7.1994, leg. Hibbs (KNHM); same location $\left(76^{\circ} 27^{\prime} 35^{\prime \prime} \mathrm{W}, 0^{\circ} 28^{\prime} 14^{\prime \prime} \mathrm{S}\right)$, but flight intercept trap, $270 \mathrm{~m}$ elevation, male, 21.-24.5.1999, leg. R. Brooks (KNHM); Napo, Tena, $500 \mathrm{~m}$ elevation, 2.3.1987, leg. K.A. Johnson (KNHM); Jatun Sacha Biol. Stat. (21 km E Puerto Napo, lowland rainforest, flight intercept trap, female, 18.7.1994, leg. Levy \& Genier (KNHM); Prov. Napo, Tiputini Res. Stat. $\left(76^{\circ} 09^{\prime} \mathrm{W}, 0^{\circ} 38^{\prime} \mathrm{S}\right)$, flight intercept trap, $220 \mathrm{~m}$ elevation, 2 males, 1 female, 5.-25.09.2000, leg. D.J. Inward \& K.A. Jackson (BMNH); Peru: Madre de Dios, Iberia, $500 \mathrm{ft}$ elevation, male, 30.4.1947, leg. J.C. Pallister (AMNH).

Diagnosis: The species can be easily differentiated from all other Neotropical Osoriellus species by the deeply emarginate sides of the pronotum and the clypeal angles. produced to long acute teeth. In contrast to $O$. sinuatoangularis and O. subsinuatus, the emargination in front of the posterior angles is margined.

Description: Length: $4.8 \mathrm{~mm}$. Colouration: Black; elytra dark red; legs and antennae brown.

Head: $0.60 \mathrm{~mm}$ long, $0.91 \mathrm{~mm}$ wide; eyes slightly prominent; sides of fore-head concavely narrowed to front angles; sides of clypeus parallel; front angles of clypeus produced to long teeth; anterior edge between lateral teeth even; setiferous punctation distinct, but weak and moderately dense; area at base of antennae and narrow midline impunctate; supraocular area more coarsely punctate than on vertex; on vertex, interstices between punctures on average as wide as diameter of punctures; netlike microsculpture distinct; surface slightly shiny.

Antennae slightly shorter than head and half of pronotum combined; second antennomere oblong; longer than wide; third conical antennomere not longer than wide; following antennomeres more or less quadrate; antennomere 4 and 5 not wider than preceding antennomeres; last 5 antennomeres distinctly thicker than preceding antennomeres, but quadrate.

Pronotum: $0.88 \mathrm{~mm}$ long, $0.95 \mathrm{~mm}$ wide; widest at anterior angles; anterior angles produced to short acute teeth; sides in anterior half nearly parallel; in posterior half slightly stronger convergent; deeply emarginate in front of posterior angles; lateral margin visible throughout its total length; setiferous punctation moderately dense and punctures much larger than on head; on average, interstices between punctures slightly shorter than diameter of punctures; wide midline impunctate; netlike microsculpture deep and partly isodiametric near anterior edge; surface slightly shiny.

Elytra: $1.08 \mathrm{~mm}$ long, $1.09 \mathrm{~mm}$ wide; with weak, but dense ground-sculpture; irregular rows of setiferous punctures distinctly visible.

Abdomen with dense setiferous punctation; microsculpture weak; on posterior tergites weaker than on anterior tergites; surface on posterior tergites polished and shiny. Protibia: $0.57 \mathrm{~mm}$ long, $0.18 \mathrm{~mm}$ wide; nearly semicircular; with 9 spines on outer edge; apical spines not inserted on digits; WLR: 3.5; in posterior aspect, comb at inner emargination partly covered; posterior face covered by long yellow setae.

Aedeagus with long abruptly curved apical lobe ending in obtuse broad apex; on inner edge with row of sensillae.

Etymology: The specific name derived from the same Latin word meaning emarginate and refers to the emarginate sides of the pronotum.

\section{Osoriellus spinosus $\mathrm{n}$. sp.}

(Figs 15A-D, 20B)

Type material: Holotype, male: Peru: Tambopata Prov. Madre de Dios Depto., $15 \mathrm{~km}$ Ne Puerto Maldonado, Reserva Cuzco Amazónica $\left(69^{\circ} 03^{\prime} \mathrm{W}, 12^{\circ} 33^{\prime} \mathrm{S}\right), 200 \mathrm{~m}$ elevation, ex. Flight intercept rap, 19.07.1989, leg. J.S. Ashe \& R.A. Leschen, \#522, Plot \#Z1U19 (KNHM).

Paratypes: Peru: 2 males with same data as holotype, 19.7.1989, 13.7.1989 (KNHM, UIC); 3 females, same data as holotype, but Plot Z2U19; 13.07.1989, \#484, Plot Z1U19, 26.06.1989, \#280, Plot \#Z1 trail 26, 2.7.1989, \#366, Plot Z2U19 (KNHM).

Diagnosis: The species resembles O. oculatus in the shape of the head and pronotum and, thus, can be easily mixed with species of the O.-oculatus-group. In contrast to the species of that group, the aedeagus of $O$. spinosus is asymmetric. The eyes are slightly less prominent than in O. oculatus. The punctation of the head is less dense, but the pronotal punctation is denser than in O. oculatus. In particular, the dentation of the clypeus differs from $O$. hanagarthi and $O$. oculatus. The pronotal shape differs distinctly from $O$. hanagarthi, since the sides are evenly narrowed such as in O. oculatus and without slight emargination. Within the O.-bicornis-group the species is characterised by the denticulate anterior edge of the clypeus. 
Description: Length: $3.5 \mathrm{~mm}$. Colouration: Dark brown; posterior margin of pronotum lighter reddish; legs and antennae light brown.

Head: $0.48 \mathrm{~mm}$ long, $0.69 \mathrm{~mm}$ wide; eyes not prominent; as long as temples; sides of fore-head narrowed in concave curve to anterior angles; clypeal angles produced to short teeth; adjacent to produced angles with additional two shorter teeth; middle of anterior edge of clypeus even; large setiferous punctation irregularly dense; on average, interstices between punctures as wide as or slightly shorter than diameter of punctures; wide midline and area at base of antennae impunctate; on punctate area with remains of irregular microsculpture; impunctate area polished; in total, surface shiny.

Antennae slightly longer than head; second antennomere oval; nearly twice as long as conical third; antennomeres four to six as wide as preceding antennomeres; antennomeres four to fife approximately quadrate; sixth nearly twice as wide as long; antennomeres seven to ten distinctly wider than preceding antennomeres and slightly wider than long.

Pronotum: $0.65 \mathrm{~mm}$ long, $0.71 \mathrm{~mm}$ wide; widest at anterior angles; evenly convergent to posterior angles; in posterior half more strongly convergent than in anterior half; posterior angles widely rounded; lateral margin extremely fine; in dorsal aspect, not visible in anterior half; setiferous punctures large and dense; in irregular rows; wide midline impunctate; on average, interstices between punctures as wide as diameter of punctures; within rows, interstices slightly shorter; between normal large punctures with dense micro-punctation; surface shiny.

Elytra: $0.78 \mathrm{~mm}$ long, $0.74 \mathrm{~mm}$ wide; with setiferous punctation in irregular rows on fine coriaceous ground sculpture; surface shiny.

Abdomen with dense setiferous punctation except on narrow impunctate midline; surface matt.

Protibia: $0.39 \mathrm{~mm}$ long, $0.14 \mathrm{~mm}$ wide; nearly semicircular; with 10 spines at outer edge; apical spines not inserted on digits; WLR: 4.0; in posterior aspect, comb at inner emargination shortly covered in middle part; posterior face with dense setation.

Aedeagus with long acute apical lobe; inner edge of apical lobe with 9 sensillae.

Etymology: The specific name derives from the same Latin word meaning spiny and refers to the spines on the front edge of the clypeus.

\section{Key to species}

1. Smaller than $4.0 \mathrm{~mm}$.

Longer than $4.0 \mathrm{~mm}$.

2. Produced angles of clypeus broad and not acute, punctation of pronotum finer.

O. bicornis n. sp.

Anterior edge of clypeus denticulate, punctation of pronotum coarse.

O. spinosus n. sp.

3. Longer than $5.0 \mathrm{~mm}$, produced angles of clypeus broad with aditional smaller teeth. O. corniculatus n. sp.

Smaller than $5.0 \mathrm{~mm}$, angles of clypeus produced to acute simple teeth.

4. Sides of pronotum deeply emarginate in front of posterior angles or lateral margin ending slightly in front of posterior angles to form a short emargination.

- Sides of pronotum more or less evenly narrowed from anterior angles to posterior angles, without even slight emargination in front of posterior angles.

5. Eyes large and distinctly prominent, longer than temples, pronotum with weak microsculpture, surface shiny. ... O. bovis n. sp.

Eyes smaller and only slightly prominent, as long as temples, pronotum with deep microsculpture, surface matt. O. cornutus n. sp.

6. Pronotum deeply emarginate in front of posterior angles, emargination margined, surface with distinct netlike microsculpture.

O. sinuatus n. sp.

- Lateral margin of pronotum ending in front of posterior angles, posterior angles only shortly emarginate. ........ 7

7. Pronotum only with remains of microsculpture, smoothly narrowed from anterior angles to posterior angles. O. sinuatoangularis $\mathrm{n}$. $\mathrm{sp}$.

Pronotum with deep netlike microsculpture, shape of pronotum trapezoidal. O. subsinuatus n. sp. 


\section{Osoriellus subsinuatus $\mathrm{n}$. sp.}

(Figs 17A-C, 20G)

Type material: Holotype, male: Peru: Tambopata Prov., $15 \mathrm{~km}$ NE Puerto Maldonado, ex. Flight intercept trap, 22.6.1989, leg. J.S. Ashe \& R.A. Leschen, \# 195 (KNHM). Paratypes: Peru: 3 females with same data as holotype, but 24.6.1989, \#195, \#246 and \#249; Tambopata Prov., Dpt O. Madre de Dios, $15 \mathrm{~km}$ NE Puerto Maldonado, Maldonado Reserva Cuzco Amazónico (12³3'S, $\left.69^{\circ} 03^{\prime} \mathrm{W}\right), 200 \mathrm{~m}$ elevation, Plot \#Z2E14, ex flight intercept trap, 1 male, 1 female, 17.6.1989, leg. J.S. Ashe \& R.A. Leschen, \# 118, 2 females with same data, but \#Z2E17, 15.6.1989, \#065; 28.6.1989, \#314 (KNHM, UIC).

Diagnosis: As in O. sinuatus and O. sinuatoangularis, slight emarginations are found at posterior angles in O. subsinuatus. Compared to those species, the emargination is smallest in O. subsinuatus. Furthermore, the pronotal microsculpture in O. subsinuatus is deeper and the surface, thus, less shiny and the punctation coarser and deeper than in O. sinuatus and O. sinuatoangularis.

Description: Length: $4.8 \mathrm{~mm}$. Colouration: Black; elytra, posterior margin of pronotum, and legs reddish; antennae yellow.

Head: $0.66 \mathrm{~mm}$ long, $0.93 \mathrm{~mm}$ wide; eyes slightly prominent and slightly longer than temples; sides of fore-head narrowed to anterior margin in concave curve; angles of clypeus produced to acute teeth; setiferous punctation irregularly deep and dense; on fore-head sparser and weaker than on vertex and with impunctate midline; interstices between punctures as wide as diameter of punctures; on supraocular area, punctures partly coriaceous and granulate; distinct microsculpture netlike; surface slightly shiny.

Antennae slightly longer than head; second antennomere globular, third conical and shorter than second; antennomeres four to six quadrate and as thick as third antennomere; antennomeres seven to ten distinctly wider than preceding antennomeres; antennomeres 7, 9, and 10 quadrate, 8 wider than long.

Pronotum: $0.93 \mathrm{~mm}$ long, $1.01 \mathrm{~mm}$ wide; widest at anterior angles; evenly convergent to posterior angles; at anterior angles, lateral margin very fine and covered in dorsal aspect; lateral margin slightly widened to posterior angles; ending shortly in front of posterior angles; at posterior angles with short and weak emargination; setiferous punctation coarse and deep; punctation partly depressed as irregular longitudinal or diagonal impressions; impunctate midline; distinct netlike microsculpture; surface slightly shiny.

Elytra: $1.08 \mathrm{~mm}$ long, $1.01 \mathrm{~mm}$ wide; with dense setiferous punctation on coriaceous ground-sculpture; surface slightly more shiny than on pronotum.

Abdomen with impunctate midline and dense setiferous punctation on each side of midline; without microsculpture; surface polished and shiny.
Protibia: $0.58 \mathrm{~mm}$ long, $0.17 \mathrm{~mm}$ wide; nearly semicirular; with 9 spines on outer edge; apical spines not inserted on digits; WLR: 5.0; in posterior aspect, comb at inner emargination visible throughout its total length; posterior face densely covered by yellow setae.

Aedeagus with long apical lobe ending in obtusely rounded apex; inner edge with 8 sensillae.

Etymology: The specific name means slightly emarginate and refers to the short and weak emargination at posterior angles of the pronotum.

\section{Osoriellus-hirtulus-group}

This species group is characterised by the dense setiferous punctation, in particular on the pronotum. The first antennomeres are short compared to the other species of the genus. The outer edge of the protibia is strongly digitate and the aedagus is relatively large, but can be symmetric to strongly asymmetric. The species are large compared to other species of the genus.

\section{Description of the species}

\section{Osoriellus hirtulus (FAUvEL, 1891) new combination (Figs 21C, 27A)}

\section{Osorius hirtulus Fauvel, 1891: 92}

Type material: Venezuela: Colonia Tovar, 2 males, 2 females, 1.11.1888, leg. E. Simon (lectotype and syntypes ISBN).

Diagnosis: Among the species of this group with dense setiferous punctation of the pronotum, O. hirtulus is characeterised by its large size and the slightly emarginate clypeus.

Description: Length: 7.4-7.8 mm. Colouration: Black, legs dark red; antennae black.

Head: $1.2 \mathrm{~mm}$ long, $1.4 \mathrm{~mm}$ wide; eyes small and not prominent, temples one-third longer than eyes; front edge of clypeus with obtuse large prominence at each side and a deep emargination between them; with deep and dense setiferous punctures; distance between punctures on average as wide as diameter of punctures; small space on posterior disc and at base of antennae without punctures; setae yellow; shorter on clypeus than on disc; without microsculpture; surface shiny.

Antennae as long as head; second antennomere globular; third oval, half times longer than second antennomere; following antennomeres approximately quadrate; increasing in width.

Pronotum: $1.4 \mathrm{~mm}$ long, $1.6 \mathrm{~mm}$ wide; widest at anterior angles; continuously convergent to obtusely rounded posterior angles; at anterior angles one-third narrower 
than at posterior angles; lateral margin slightly elevated to posterior angles; setiferous punctures deeper and denser than on head; with wide impunctate midline; yellow setae long; pointing posteriad; without microsculpture; surface polished.

Elytra: $1.5 \mathrm{~mm}$ long, $1.35 \mathrm{~mm}$ wide; with similar punctation as on pronotum, but with weak coriaceous ground-sculpture, surface less shiny than pronotum; yellow setae pointing backwards.

Abdomen with similar setiferous punctation as on elytra and pronotum; base of abdominal segments with small transverse depression.

Protibia: $1.01 \mathrm{~mm}$ long, $0.32 \mathrm{~mm}$ wide; 8 spines on outer edge; apical spines on long digits; WLR: 0.4 ; in posterior aspect, comb of inner emargination nearly totally visible; posterior face sparsely covered by long yellow setae; on average, setae as long as protibial width.

Aedeagus nearly symmetric; apical lobe narrow and slightly pointing to left side.

\section{Osoriellus pubescens n. sp.}

(Figs 23A-C, 27D)

Type material: Holotype, male: Panama: Veraguas, $6.1 \mathrm{~km} \mathrm{~N}$ of Santa Fe, Cerro Tute $\left(81^{\circ} 07.06^{\prime} \mathrm{W}, 8^{\circ} 30.30^{\prime} \mathrm{N}\right)$, $1220 \mathrm{~m}$ elevation, cloud forest litter, 13.6.1996, leg. R. Anderson, \#PAN2A96 96-127D (KNHM).

Paratypes: Panama: Chiriqui, La Fortuna, Continental Divide Trail $\left(82^{\circ} 12.0^{\prime} \mathrm{W}, 8^{\circ} 46.0^{\prime} \mathrm{N}\right), 1200 \mathrm{~m}$ elevation, berlese forest litter, abdomen lost, 9.6.1995, leg. R. Anderson, \#PAN 2A95 10B (UIC); Costa Rica: Alajuela, Peñas Blancas, $850 \mathrm{~m}$ elevation, sifted fruit and flower fall, female, 18.5.1989, leg. J. Ashe, R. Brooks, R. Leschen (KNHM).

Diagnosis: The species resembles $O$. setosus cencerning the size and shape of the pronotum. It can be differentiated from that species by the asymmetric shape of the aedeagus and the evenly punctate head.

Description: Length: $6.5 \mathrm{~mm}$. Colouration: Black; legs and antennae brown.

Head: $0.91 \mathrm{~mm}$ long, $1.29 \mathrm{~mm}$ wide; eyes moderately large; as long as temples; sides of fore-head emarginate; anterior edge of clypeus even; setiferous punctation even; on average, interstices between punctures as wide as diameter of punctures; small area on central posterior vertex and at base of antennae impunctate; punctures close to neck partly granulate; netlike microsculpture weak; surface shiny.

Antennae slightly longer than head; second antennomere globular; as long as third; following antennomeres four to seven approximately quadrate; antennomeres eight to ten slightly longer than wide.

Pronotum: $1.32 \mathrm{~mm}$ long; $1.52 \mathrm{~mm}$ wide; widest at anterior angles; evenly narrowed to widely rounded posterior angles; anterior angles produced to short acute teeth; lateral margin fine; finer at anterior angles than at posterior angles; setiferous punctation dense and deep; narrow midline impunctate; interstices between punctures one fourth as wide as diameter of punctures; without microsculpture except remains of weak netlike microsculpture close to posterior margin; surface shiny.

Elytra: $1.53 \mathrm{~mm}$ long, $1.44 \mathrm{~mm}$ wide; as densely and deeply punctate as pronotum, but setiferous punctures hardly visible in deep coriaceous ground-sculpture.

Abdomen with sparser setiferous punctation than forebody; moderately wide midline on tergites impunctate; netlike microsculpture distinct.

Protibia: $0.92 \mathrm{~mm}$ long, $0.27 \mathrm{~mm}$ wide; 8 long spines at outer edge; apical four spines inserted on moderately long digits; WLR: 0.8; in posterior aspect, comb of inner emargination visible throughout its total length; posterior face with moderately dense setation; on average, setae as long as half of protibial width.

Aedeagus rectangularly angulate; asymmetric; left side of apical lobe with moderately large basal plate; right side without central tooth; both sides of inner edge with few setae.

Etymology: The specific name refers to the dense setiferous punctation of the total body.

\section{Osoriellus pubicollis $\mathrm{n}$. sp. \\ (Figs 24A, C, 27B)}

Type material: Holotype, male: Panama: Veraguas, Cerro Tute, $4 \mathrm{~km} \mathrm{~W}$ of Santa Fe, $850 \mathrm{~m}$ elevation, male, 30.7.1995, leg. Gillogly (KNHM).

Paratypes: Panama: 1 female and 2 males with same data as holotype (KNHM); Costa Rica: Cartago Prov., Ref. Nac. de Fauna Silvestre Tapanti, $1.5 \mathrm{~km}$ E Station $\left(83^{\circ} 46.90^{\prime} \mathrm{W}, 9^{\circ} 44.97^{\prime} \mathrm{N}\right), 1240 \mathrm{~m}$ elevation, flight intercept trap, female, 30.10.-1.11.2001, leg. R. Brooks, \#CR1B01 14 (KNHM, UIC); Ecuador: Napo Prov., $25 \mathrm{~km}$ W Tena, Tena-Talag Grande Road, $2000 \mathrm{ft}$ elvation, litter near stream, female, 23.5.1993, leg. L. Herman, \#2739 (AMNH); Napo Prov. 69 km NE Baeza, 15 km SW Reventador, $4600 \mathrm{ft}$ elevation, (without abdomen), litter, 28.-30.10.1988, leg. L. Herman (AMNH).

Diagnosis: Among the O.-hirtulus-group, O. pubicollis is characterised by the polished and shiny pronotum. Additionally, compared to O. setosus and O. pubescens, the pronotum is less convergent from anterior to posterior angles.

Description: Length: $5.8 \mathrm{~mm}$. Colouration: Dark brown; legs and antennae lighter brown.

Head: $0.86 \mathrm{~mm}$ long, $1.14 \mathrm{~mm}$ wide; eyes moderately large; not prominent; as long as temples; sides of forehead emarginate; anterior edge of clypeus even with two minute granules at angles; setiferous punctation on vertex denser than on fore-head; wide midline and area at base 
of antennae impunctate; very weak netlike microsculpture; more distinct on punctate areas; surface moderately shiny.

Antennae slightly longer than head; second antennomere globular and as long as third; following antennomeres approximately quadrate; sixth to eleventh antennomeres thicker than preceding antennomeres.

Pronotum: $1.14 \mathrm{~mm}$ long, $1.26 \mathrm{~mm}$ wide; widest at anterior angles; slightly convergent to posterior angles; posterior angles widely rounded; lateral margin fine; finer at anterior angles than at posterior angles; setiferous punctation dense and deep; on average, interstices between punctures half as wide as diameter of punctures; wide midline impunctate; without microsculpture; surface polished and shiny.

Elytra: $1.34 \mathrm{~mm}$ long, $1.27 \mathrm{~mm}$ wide; as densely and deeply punctate as on pronotum; setiferous punctures hardly visible in coriaceous ground-sculpture.

Abdomen with dense setiferous punctation and narrow impunctate midline on tergites; netlike microsculpture weak; surface slightly shiny.

Protibia: $0.68 \mathrm{~mm}$ long, $0.20 \mathrm{~mm}$ wide; 8 spines at outer edge; apical four spines inserted on short teeth; WLR: 0.9; in posterior aspect, comb of inner emargination visible throughout its total length; posterior face with moderately dense setation; on average, setae as long as protibial width.

Aedeagus rectangularly angulate; asymmetric; left side of apical lobe with large basal plate; right side with central tooth; both sides of inner edge with several setae; apical lobe sinuate ending in hook-like acute apex.

Etymology: The specific name means with dense setose pronotum.

\section{Osoriellus setifer $\mathrm{n} . \mathrm{sp}$.} (Figs 26A, C, 27F)

Type material: Holotype, male: Peru: Madre de Dios, Pentiacolla Lodge, Alto Madre de Dios River, $\left(71^{\circ} 13.55^{\prime} \mathrm{W}\right.$, $\left.12^{\circ} 39.22^{\prime} \mathrm{S}\right), 400 \mathrm{~m}$ elevation, collected by flight intercept trap, 23.-26.10.2000, leg. R. Brooks (KNHM).

Diagnosis: Among the species of this group with dense setation on the fore-body, this species can be differentiated by the flattened area at posterior pronotal angles. The aedeagus is symmetric as in O. setosus, but the apical lobe is thicker.

Description: Length: $6.1 \mathrm{~mm}$. Colouration: Dark brown; legs and antenne slightly lighter brown.

Head: $0.69 \mathrm{~mm}$ long, $1.10 \mathrm{~mm}$ wide; eyes not prominent, slightly longer than temples; sides of fore-head strongly narrowed in front of eyes; clypeus trapezoidal; anterior edge even; setiferous punctation moderately weak; with wide impunctate midline on vertex; on clypeus punctures deeper than on vertex; yellow setae long; on supraocu- lar area punctures slightly granulate; punctate area with dense netlike microsculpture; surface matt; impuncate midline without microsculpture; surface shiny.

Antennae slightly longer than head and half of pronotum combined; second antennomere oval; third conical and slightly longer than second; following antennomeres more or less quadrate; not increasing in width.

Pronotum: $1.19 \mathrm{~mm}$ long, $1.36 \mathrm{~mm}$ wide; widest in anterior third; slightly narrowed to anterior angles; more strongly narrowed to posterior angles; in front of posterior angles slightly emarginate; sides close to posterior angles nearly parallel; in dorsal aspect, lateral margin visible throughout ist total length; close to posterior angles slightly thicker than at anterior angles; flattened at anterior angles; setiferous punctation dense and even except at wide impuncate midline; punctures deeper than on head; interstices between punctures slightly shorter than diameter of punctures; irregular microsculpture extremely weak; surface shiny.

Elytra: $1.37 \mathrm{~mm}$ long, $1.40 \mathrm{~mm}$ wide; with distinctly rectangular shoulders; widest in posterior third; coriaceous ground sculpture weak; dense setiferous punctation distinctly visible; yellow setae long.

Abdomen with dense setiferous punctation and long yellow setae except on moderately wide impunctate midline; netlike microsculpture deep; surface matt.

Protibia: $0.74 \mathrm{~mm}$ long, $0.19 \mathrm{~mm}$ wide; slender; 8 spines at outer edge; apical spines inserted on moderately long digits; WLR: 0.9; in posterior aspect, comb of inner emargination visible throughout its total length; posterior face with moderately dense setation; on average, setae slightly shorter than protibial width.

Aedeagus rectangularly angulate; both lobes equal in length; apical lobe narrowed to thick apex; apex curved to short hook.

Etymology: The specific name means carrying setae.

\section{Osoriellus setosus n. sp.}

(Figs 22B, C, 27E)

Type material: Holotype, male: Ecuador: Napo, $81 \mathrm{~km}$ NE Baeza, 3 km SW Reventador, $5300 \mathrm{ft}$ elevation, litter, 28., 29.10.1988, leg. L. Herman (AMNH).

Paratypes: Ecuador: Napo Prov. 5 km S. Baeza, on Road to Tena, 1700 m elevation, under rocks and logs, 2 males, 28.4.1990, leg. C. Carlton \& R. Adrave (KNHM); Napo Prov. $81 \mathrm{~km}$ NE Baeza, $3 \mathrm{~km}$ SW Reventador, $5300 \mathrm{ft}$ elevation, litter, 2 males, 2 females, 28., 29.10.1988, leg. L. Herman (AMNH, UIC); Prov. Napo, Cosanga $\left(77^{\circ} 51.52^{\prime} \mathrm{W}, 0^{\circ} 34.45^{\prime} \mathrm{S}\right), 1950 \mathrm{~m}$ elevation, beating of forest vegetation, female, 25.11.2009, leg. L. Sekerka \& K. Stajerova (BMNH).

Diagnosis: Among the O.-hirtulus-group, O. setosus can be easily identified by the symmetric aedeagus, similar as in O. setifer. The species is larger than O. setulosus 
and O. pubicollis, but smaller than O. hirtulus. Compared to O.pubicollis, the pronotum is more triangular. It resembles $O$. pubescens in shape and size. However, the aedeagus of $O$. pubescens is asymmetric like in $O$. setulosus and O. pubicollis.

Description: Length: $6.6 \mathrm{~mm}$. Colouration: Brown; pronotum and abdominal segments III-VI lighter brown; legs and antennae light brown.

Head: $1.11 \mathrm{~mm}$ long, $1.44 \mathrm{~mm}$ wide; eyes moderately large; not prominent; as long as temples; sides of fore-head emarginate; anterior edge of clypeus even; setiferous punctation irregularly dense; on fore-head sparser than close to neck; close to neck, interstices between punctures one fourth as wide as diameter of punctures; small area on central posterior vertex and at base of antennae impunctate; on supraocular area punctures partly granulate; netlike microsculpture weak; surface shiny.

Antennae slightly longer than head; second antennomere globular; as long as third; following antennomeres approximately quadrate.

Pronotum: $1.36 \mathrm{~mm}$ long, $1.55 \mathrm{~mm}$ wide; widest at anterior angles; evenly convergent to widely rounded posterior angles; anterior angles produced to short acute teeth; lateral margin fine; finer at anterior angles than at posterior angles; setiferous punctation deep and dense; interstices between punctures half as wide as diameter of punctures; moderately wide midline impunctate; without microsculpture; surface shiny.
Protibia: $0.81 \mathrm{~mm}$ long, $0.24 \mathrm{~mm}$ wide; 8 spines at outer edge; apical four spines inserted on short teeth; WLR: 0.7; in posterior aspect, comb of inner emargination visible throughout its total length; posterior face with moderately dense setation; on average, setae slightly longer than half of protibial width.

Aedeagus symmetric; apical lobe triangular; smoothly curved to acute angle.

Etymology: The specific name refers to the dense setiferous punctation of the total body.

\section{Osoriellus setulosus n. sp.}

(Figs 25A, C, 27C)

Type material: Holotype, male: Panama, Chiriqui, La Fortuna, Hydrological Station Trail $\left(82^{\circ} 12.0^{\prime} \mathrm{W}, 8^{\circ} 42.0^{\prime} \mathrm{N}\right)$, forest litter, Berlese, male, 9.6.1995, leg. R. Anderson, \#PAN2A95 13A, (KNHM).

Diagnosis: Among the O.-hirtulus-group, O. setulosus is the smallest species. It can be identified by the small size and the dense and deep microsculpture of the pronotum.

Description: Length: $4.8 \mathrm{~mm}$. Colouration: Reddish brown; legs and antenne lighter brown.

Head. $0.68 \mathrm{~mm}$ long, $0.94 \mathrm{~mm}$ wide; eyes short and not prominent; temples twice as long as eyes; fore-head elongate; slightly emarginate to anterior angles; anterior edge

Key to the species

1. Large species of $7.4-7.8 \mathrm{~mm}$, front edge of clypeus deeply emarginte; angles produced to broad prominences. .. O. hirtulus (FAUveL, 1891)

Smaller species between $4.8 \mathrm{~mm}$ and $7 \mathrm{~mm}$, front edge of clypeus even.

2. Surface of pronotum between dense pubescent punctation with dense microsculpture, matt. ..... O. setulosus n. sp.

Surface of pronotum between dense pubescent punctation without microsculpture, shiny.

3. Sides of pronotum in front of posterior angles slightly emarginate and flattened. O. setifer n. sp.

Sides of pronotum evenly narrowed to posterior angles and not flattened at posterior angles.

4. Smaller species between $5.0-6.0 \mathrm{~mm}$ length; pronotum subparallel.

O. pubicollis n. sp.

Larger species between 6.4 - $7.0 \mathrm{~mm}$ length, pronotum more trapezoidal.

5. Punctation of head irregularly dense, close to neck denser than on fore-head; aedeagus symmetric.

O. setosus n. sp.

Density of punctation of head even; aedeagus asymetric.

O. pubescens n. sp.

Elytra: $1.62 \mathrm{~mm}$ long, $1.52 \mathrm{~mm}$ wide; as densely and deeply punctate as pronotum, but setiferous punctures hardly visible in deep coriaceous ground-sculpture.

Abdomen with dense setiferous punctation; punctation slightly sparser than on pronotum; narrow midline impunctate; with weak netlike microsculpture. of clypeus even; setiferous punctation dense, but not deep; on average, interstices between punctures shorter than diameter of punctures; longitudinal area on central vertex and area at base of antennae impunctate; netlike microsculpture distinct; surface matt.

Antennae slightly longer than head; second antennomere globular; third antennomere quadrate; fourth to 
sixth antennomeres slightly wider than long; following antennomeres approximately quadrate and only slightly thicker than preceding antennomeres.

Pronotum: $0.94 \mathrm{~mm}$ long, $1.08 \mathrm{~mm}$ wide; widest closely behind anterior angles; evenly convergent to posterior angles; posterior angles widely rounded; lateral margin fine; finer at anterior angles than at posterior angles; in dorsal aspect, visible througout its total length; setiferous punctation deep and dense; on average, interstices between punctures shorter than diameter of punctures; moderately wide midline impunctate; netlike microsculpture distinct; surface matt.

Elytra: $1.12 \mathrm{~mm}$ long, $1.04 \mathrm{~mm}$ wide; as densely and deeply punctate as pronotum, but setiferous punctures hardly visible in coriaceous ground-sculpture; surface matt.

Abdomen with dense setiferous punctation and moderately wide impunctate midline on tergites; netlike microsculpture weaker than on head and pronotum and surface shinier.

Protibia: $0.55 \mathrm{~mm}$ long, $0.15 \mathrm{~mm}$ wide; slender; 7 spines at outer edge; apical spines inserted on short digits; WLR: 1.6; in posterior aspect, comb of inner emargination visible throughout its total length; posterior face with several long yellow setae; on average, setae slightly shorter than protibial width.

Aedeagus rectangularly angulate; asymmetric; left side with thick apical plate; few setae on both sides of inner edges; apical lobe sinuate ending in hook-like acute apex.

Etymology: The specific name means with many setae and refers to the densely setose body.

\section{Osoriellus-granarius-group}

The species of this group are very large. They are mainly characterised by the strongly sclorotised aedeagus that may be symmetric or asymmetric, but has always a central opening. The pronotal punctures carry short setae.

\section{Description of the species}

Osoriellus anceps $\mathrm{n} . \mathrm{sp}$.

(Figs 29A, C, 31B)

Type material: Holotype, male: Peru: Madre de Dios, Pantiacolla Lodge, 4-7 km NW, El Mirador Trail, 500-800 m elevation, Alto Madre de Dios River $\left(12^{\circ} 39.10^{\prime} \mathrm{S}, 71^{\circ} 15.28^{\prime} \mathrm{W}\right)$, collected on logs, 23.10.2000, leg. R. Brooks, \#PERU1800 080 (KNHM).

Diagnosis: The species can be easily identified by the specific structure of the clypeus. According to the deep emargination of the clypeus, it resembles O. cornifrons, but the broad triangular prominences are only present in O. anceps.
Description: Length: $9.5 \mathrm{~mm}$. Colouration: Black; legs and antennae dark brown.

Head: $1.35 \mathrm{~mm}$ long, $1.86 \mathrm{~mm}$ wide; eyes slightly prominent and slightly longer than temples; sides of fore-head deeply emarginate; sides of clypeus parallel; anterior angles of clypeus produced to broad triangles; between triangles with deep semicircular emargination; mandibles elongate and prominent; setiferous punctation deep; impunctate areas at base of antennae and on midline of vertex; interstices between punctures as wide as or slightly shorter than diameter of punctures; netlike microsculpture deep; surface matt.

Antennae as long as head; second antennomere oval; third conical and slightly shorter than second; fourth antennomere slightly longer than wide; following antennomeres approximately quadrate and and slightly increasing in width.

Pronotum: $1.81 \mathrm{~mm}$ long, $1.91 \mathrm{~mm}$ wide; widest at obtuse anterior angles; slightly narrowed in anterior half; more distinctly narrowed in posterior half; lateral margin finer in anterior half than in posterior half; setiferous punctation deep, but distinctly sparser than on head; moderately wide midline impunctate; interstices between punctures irregular; ranging from as wide as to twice as wide as diameter of punctures; in posterior half small areas impunctate; netlike microsculpture weaker than on head and surface shinier.

Elytra: $2.09 \mathrm{~mm}$ long, $2.00 \mathrm{~mm}$ wide; with coriaceous ground-sculpture; setiferous punctation in irregular rows; punctures hardly visible in ground-sculpture.

Abdomen with dense setiferous punctation; punctation still denser than on head; netlike microsculpture deep and dense; surface matt.

Protibia: $1.09 \mathrm{~mm}$ long, $0.38 \mathrm{~mm}$ wide; thick and nearly semicircular; 9 spines at outer edge; apical spines inserted on extremely short digits; WLR: 3.0; in posterior aspect, comb of inner emargination shortly covered in middle; posterior face with dense yellow setation; on average, setae slightly longer than half of protibial width.

Aedeagus broad and thick; rectangularly angulate; apical lobe slightly sinuate; ending in thick obtuse apex.

Etymology: The specific name derived from the same Latin word meaning on both sides and refers to the two prominent triangles on both sides of the clypeus.

\section{Osoriellus cornifrons n. sp.}

(Figs 30A, C, 31C)

Type material: Holotype, male: Ecuador: Sucumbios, Sacha Lodge $\left(76.05^{\circ} \mathrm{W}, 0^{\circ} .05^{\prime} \mathrm{S}\right)$, sampled by Malaise trap, male, 27.8.-10.9.1994, leg. W. Hibbs (KNHM).

Paratypes: Ecuador: Sucumbios, Sacha Lodge $\left(0^{\circ} 28.14\right.$ 'S, $\left.76^{\circ} 27.35^{\prime} \mathrm{W}\right), 270 \mathrm{~m}$ elevation, sampled by flight intercept trap, male, 21.-24.3.1999, leg. R. Brooks, \#ECU1B99047 (head an pronotum lost) (KNHM); Sucumbios Prov., Sacha Lodge $\left(0.5^{\circ} \mathrm{S}, 76.5^{\circ} \mathrm{W}\right), 250 \mathrm{~m}$ elevation, collected 
by flight intercept trap, 2 males, 26.-28.10.2004, leg. G. de Rougemont (UIC); Prov. Napo, Tiputini Res. Stat. (76 $\left.09^{\prime} \mathrm{W}, 0^{\circ} 38^{\prime} \mathrm{S}\right)$, flight intercept trap, 1 male, 2 females, 5-25.09.2000, leg. D.J. Inward \& K.A. Jackson (BMNH).

Diagnosis: Among the three species of the O.-granariusgroup, $O$. cornifrons resembles $O$. anceps in the structure of the head. It is distinctly smaller than O. anceps and as large as O.granarius. The aedeagus also resembles O. granarius, but the long acute, hook-like apex is asymmetric.

Description: Length: $6.9 \mathrm{~mm}$. Colouration: Black; legs and antennae dark brown.

Head: $0.93 \mathrm{~mm}$ long, $1.34 \mathrm{~mm}$ wide; eyes slightly prominent; sides of fore-head shortly emarginate; sides of clypeus parallel; anterior edge of clypeus widely emarginate; anterior angles broadly produced and each ending in short acute tooth; setiferous punctation irregularly dense and moderately deep; on clypeus and at neck denser than on vertex; area at base of antennae impunctate; supraocular punctures granulate; microsculpture distinct; netlike on vertex and clypeus; longitudinally reticulate on impunctate area at base of antennae; surface matt.

Antennae slightly longer than head; second antennomere oval; as long as conical third; following antennomeres approximately quadrate and slightly increasing in width.

Pronotum: $1.35 \mathrm{~mm}$ long, $1.38 \mathrm{~mm}$ wide; widest at anterior angles; evenly narrowed in smooth curve to posterior angles; posterior angles widely rounded; lateral margin finer in anterior half than in posterior half; in dorsal aspect, not visible slightly behind anterior angles; setiferous punctation large, deep and coarse; punctures much larger than on head; midline impunctate; on average, interstices between punctures half as wide as diameter of punctures; netlike microsculpture deep, but wider than on head; surface slightly shiny.

Elytra: $1.57 \mathrm{~mm}$ long, $1.42 \mathrm{~mm}$ wide; setiferous punctation dense and in irregular rows; coriaceous ground-sculpture weak; punctures distinctly visible; surface more shiny than on pronotum.

Abdomen with dense setiferous punctation; netlike microsculpture on anterior tergites much denser and deeper than on posterior tergites; surface moderately shiny.

Protibia: $0.71 \mathrm{~mm}$ long, $0.24 \mathrm{~mm}$ wide; thick and nearly semicircular, 10 spines at outer edge; apical spines on short digits; WLR: 1.4; in posterior aspect, inner comb of emargination visible throughout its total length; poste- rior face with dense setation; on average, setae as long as half of protibial width.

Aedeagus oval; rectangularly angulate; apical lobe triangular, long and asymmetric; apex acute and curved.

Etymology: The specific name is a combination of the epithet cornus meaning horn and frons meaning front of head and refers to the two prominent lobes on both sides of the clypeus.

\section{Osoriellus granarius $\mathrm{n}$. sp. \\ (Figs 28A-C, 31A)}

Type material: Holotype, male: Bolivia: Cochabamba Prov., Cochabamba, $109 \mathrm{~km}$ E Yungas, (Cochabamba Villa Tunari Rd.) $\left(65^{\circ} 42.29^{\prime} \mathrm{W}, 17^{\circ} 08.50^{\prime} \mathrm{S}\right), 1480 \mathrm{~m}$ elevation, collected by flight intercept trap, 8.-12.Feb.1999, leg. R. Hanley, \#BOL1H99072 (KNHM).

Paratypes: Bolivia: 1 male with same data as holotype (KNHM); La Paz, cloud forest near Chulumani, $1600 \mathrm{~m}$ elevation, male, 22.-29.3.1990, leg. M. Cooper (BMNH); Santa Cruz, Amboro National Park, Los Volcanes $\left(63^{\circ} 36^{\prime} \mathrm{W}, 18^{\circ} 06^{\prime} \mathrm{S}\right), 1000 \mathrm{~m}$ elevation, underground pit trap, 20.11.-12.12.2004, male, leg. H. Mendel \& M.V.L. Barclay (BMNH); Dept. Santa Cruz, $3.7 \mathrm{~km}$ SSE Buena Vista, Hotel Flora y Fauna $\left(63^{\circ} 33.15^{\prime} \mathrm{W}\right.$, $\left.17^{\circ} 29.95^{\prime} \mathrm{S}\right), \quad 400-440 \mathrm{~m}$ elevation, secondary forest, flight intercept trap, 1 male, 1 female, 2.-9.XI.2002, leg. R. Leschen, \#BOL1L02-056 (KNHM, UIC).

Diagnosis: Among the species of the O.-granarius-group, O. granarius is conspicuous by the even front edge of the clypeus. Regarding the absence of distinct digits on the outer edge of the protibia, it resembles the large species O. parcus of the O.-s. str.-group. It can be differentiated from that species by the posteriorly less convergent sides of the pronotum and the slightly widened lateral margin in the posterior half of the pronotum.

Description: Length: $6.9 \mathrm{~mm}$. Colouration: Black; legs and antennae light brown.

Head: $1.35 \mathrm{~mm}$ long, $1.74 \mathrm{~mm}$ wide; eyes not prominent; as long as temples; sides of fore-head strongly narrowed in concave curve; front edge of clypeus only half as wide as distance between eyes; front edge of clypeus smoothly emarginate, but without produced teeth at outer angles; setiferous punctation deep and dense; on vertex, inter-

Key to the species of the granarius-group

1. Large species of $9.5 \mathrm{~mm}$, front edge of clypeus deeply emarginate; angles produced to broad prominences. O. anceps n. sp.

Smaller species of $6.9 \mathrm{~mm}$ length, front edge of clypeus either even or emarginate. 2

2. Front edge of clypeus emarginate, anterior angles produced to broad lobes with short acute tooth. O. cornifrons $\mathrm{n} . \mathrm{sp}$.

Front edge of clypeus even, anterior angles not produced. O. granarius $\mathrm{n} . \mathrm{sp}$. 
stices between punctures approximately half as wide as diameter of punctures; on fore-head, interstices on average wider; netlike microsculpture moderately deep; surface slightly shiny.

Antennae slightly longer than head; second antennomere oval; third conical; both antennomeres slightly longer than wide; following antennomeres approximately quadrate and increasing in width.

Pronotum: $1.54 \mathrm{~mm}$ long, $1.76 \mathrm{~mm}$ wide; widest at anterior angles; anterior angles shortly produced to small teeth; smoothly and evenly convergent to shortly rounded posterior angles; lateral margin distinct, but, in dorsal aspect, not visible close to anterior angles; setiferous punctation coarser and deeper than on head; adjacent to impunctate midline in irregular rows; on lateral disc irregularly punctate; partly interstices between punctures less wide than half of diameter of punctures; partly interstices wider than diameter of punctures; netlike microsculpture moderately deep; surface slightly shiny.

Elytra: $1.76 \mathrm{~mm}$ long, $1.76 \mathrm{~mm}$ wide; with coariaceous ground-sculpture; setiferous punctures in irregular rows; punctures hardly visible in dense ground-sculpture; surface less shiny than on pronotum.

Abdomen with dense setiferous punctation except impuncate midline on tergites IV to VI; anterior tergites with weak microsculpture; surface shiny; tergites VII and VIII with dense netlike microsculptre; surface matt.

Protibia: $0.76 \mathrm{~mm}$ long, $0.27 \mathrm{~mm}$ wide; thick and nearly semicircular; 9 spines at outer edge; apical spines on short digits; WLR: 2.1; in posterior aspect, comb of inner emargination totally visible; posterior face densely coverd by moderately long setae; on average, setae half as long as protibial width.

Aedaegus thick and broad; rectangularly angulate; apical lobe continued to thin acute and hook-like curved apex.

Etymology: The specific name derived from the same Latin word meaning granulate and refers to the granulate punctures on the supraocular area.

\section{Osoriel/us-guiananus-group}

This species of this group are large compared to the other species of the genus. A setiferous punctation is absent. The digits at the outer edge of the protibia are long. The aedeagus can be symmetric or asymmetric with a lateral opening. Several species have a characteristic elongate punctation, at least on the abdominal segments VII and/ or VIII.

\section{Description of the species}

Osoriellus breviceps (Notman, 1925) new combination (Figs 33A-C, 41C)

Osorius breviceps Notman, 1925: 7
Type material examined: Paraguay: San Bernardino, under stones, female, Dec. 27. 1927?, leg. K. Fiebig (holotype in $\mathrm{NMNH}$ ).

Further material examined: Paraguay: Puerto Presidente Stroessner, Hungarian Soil-Zool.Exp. male, 26.12.1965, leg. Loksa (NHMH).

Diagnosis: Within the O.-guiananus-group, O. breviceps is characterised by the trapezoidal shape of the pronotum and the short setae in the punctures. Concerning the microsculpture, O. breviceps resembles O. melancholicus and $O$. macrops, but the pronotal sides in O. melancholicus are slightly sinuate in front of the posterior angles and in $O$. macrops the sides are more convex. Thus, the posterior angles are nearly rectangular in O. melancholicus and more widely rounded in $O$. macrops, whereas they are forming obtuse angles in $O$. breviceps.

Description: Length: $6.5 \mathrm{~mm}$. Colouration: Black; antennae and legs brown, tibiae yellow.

Head: $0.80 \mathrm{~mm}$ long, $1.20 \mathrm{~mm}$ wide; eyes distinctly prominent, slightly longer than temples; punctation on disc deep and moderately dense; punctures partly granulate; on posterior vertex interstices between punctures shorter than half of diameter of punctures; on anterior vertex, interstices between punctures wider; on average, slightly shorter than diameter of punctures; on supraocular area, eyes with striate punctation; surface with netlike microsculpture, slightly shiny.

Antennae short and thick; slightly longer than head; second antennomere oblong, third conical, but not longer than second; following three antennomeres approximately quadrate; seventh to tenth antennomeres distinctly wider than preceding antennomeres; wider than long.

Pronotum: $1.35 \mathrm{~mm}$ long, $1.40 \mathrm{~mm}$ wide; widest at anterior angles; evenly convergent to posterior angles; shape trapezoidal; lateral margin narrow, in dorsal aspect, close to anterior angles not visible; wider in posterior half, but still narrow; punctures deeper and larger than on head and with very short setae; on small part adjacent to midline coriaceous; on average, interstices between punctures half as wide as diameter of punctures; microsculpture netlike and weak; surface distinctly shinier than on head.

Elytra: $1.50 \mathrm{~mm}$ long, $1.40 \mathrm{~mm}$ wide; with coriaceous ground-sculpture; punctation much finer than on head, but still dense, hardly visible in deep groundsculpture.

Abdomen with dense setiferous punctation; microsculpture weak and netlike, surface more or less shiny.

Protibia: $0.53 \mathrm{~mm}$ long, $0.17 \mathrm{~mm}$ wide; outer edge with 7 spines; apical spines inserted on moderately long digits; WLR: 0.61; in posterior aspect, comb of inner emargination totally visible; posterior face sparsely covered by long yellow setae. 
Aedeagus with moderately long, triangular apical lobe; apex of apical lobe shortly rounded; inner edge of apical lobe with sparse row of sensillae.

\section{Osoriellus diversus n. sp.}

(Figs 37A-C, 41D)

Type material: Holotype, male: Peru: Dept. Loreto, Campamento San Jacinto $\left(75^{\circ} 51.77^{\prime} \mathrm{W}, 2^{\circ} 18.75^{\prime} \mathrm{S}\right)$, 175-215 m elevation, collected by flight intercept trap, 9.7.1993, leg. R. Leschen (KNHM).

Paratype: Peru: Madre de Dios, Pantiacolla Lodge, $5.5 \mathrm{~km}$ NW El Mirador Trail, Alto Madre do Dios River $\left(71^{\circ} 15.28^{\prime} \mathrm{W}, 12^{\circ} 39.1^{\prime} \mathrm{S}\right), 500 \mathrm{~m}$ elevation, collected by flight intercept trap, male, 23-26.10.2000, leg. R. Brooks (UIC); Dept. Loreto, $1.5 \mathrm{~km} \mathrm{~N}$. Teniente Lopez (7606.92'W, $\left.2^{\circ} 35.66^{\prime} \mathrm{S}\right), 210-240 \mathrm{~m}$ elvetion, collected by flight intercept trap, male, 20.7.1993, leg. R. Leschen (KNHM).

Diagnosis: O.diversus closely resembles O. solidus concerning the polished surface, the obtuse posterior angles of the pronotum and the dense pronotal micropunctation. In contrast to $O$. solidus, $O$. diversus is smaller and the posterior angles of the pronotum are more widely rounded.

Description: Length: $6.4 \mathrm{~mm}$. Colouration: Black; legs and antennae dark brown; elytra dark reddish.

Head: $0.87 \mathrm{~mm}$ long, $1.28 \mathrm{~mm}$ wide; eyes slightly prominent; longer than temples; fore-head deeply emarginate; sides of clypeus parallel; anterior edge of clypeus widely emarginate; thus, angles slightly produced; punctation deep and irregular; large area on vertex and at base of antennae impunctate; two pairs of setiferous punctures each on both clypeus on line between posterior edge of eyes on supraocular area; punctures on supraocular and postocular area partly coriaceous and striate; much denser than normal punctation; extremely weak remains of microsculpture; surface nearly polished and shiny.

Antennae as long as head and one third of pronotum combined; second antennomere oval and elongate; third conical and slightly shorter than second; fourth antennomere also conical and slightly shorter than third; following antennomeres increasing in width, but all approximately quadrate.

Pronotum: $1.21 \mathrm{~mm}$ long, $1.36 \mathrm{~mm}$ wide; widest at anterior angles; slightly narrowed in even curve to posterior angles; posterior angles distinct, but obtusely rounded; lateral margin finer in anterior half than in posterior half; in dorsal aspect, not visible close to anterior angles; slightly widened near posterior angles; punctation deep and moderatly dense; on average, interstices between punctures as long as diameter of punctures; without distinct impunctate midline; few setiferous punctures along anterior margin and one pair of setiferous punctures in posterior half; between normal coarse punctation with micro-punctation; very weak remains of netlike microsculpture; surface nearly polished, shiny.

Elytra: $1.47 \mathrm{~mm}$ long, $1.45 \mathrm{~mm}$ wide; widest in posterior third, but sides nearly parallel; punctation coarse and dense; coriaceous ground-sculpture weak.

Abdomen with sparse punctation on tergites III - VI and weak microsculpture; surface shiny; punctation on tergites VII and VIII much denser and punctures elongate; surface with dense longitudunal reticulate microsculpture; surface matt.

Protibia: $0.78 \mathrm{~mm}$ long, $0.21 \mathrm{~mm}$ wide; 8 spines on outer edge; apical 4 spines inserting on long teeth; WLR: 0.57; in posterior aspect, inner emargination with comb distinctly visible throughout its total length; posterior face sparsely covered by long yellow setae.

Aedaegus with thick basal and apical lobe; apex of apical lobe thick and obtusely rounded; four sensillae at apex and row of sensillae at inner edge of apical lobe.

Etymology: The specific name diversus derives from the same Latin word and means different. It refers to the varying size of punctures on the pronotum.

\section{Osoriellus guiananus (BERNHAUER, 1934) new combination \\ (Figs 32A-C, 41A)}

Osorius guiananus Bernhauer, 1934: 157

Type material examined: Guyana: Essequibo River, Moravalli Creek $\left(58^{\circ} 38^{\prime} \mathrm{W}, 6^{\circ} 24^{\prime} \mathrm{N}\right)$, female, 30.8.1929, leg. Oxford Univ. Expedition (holotype in FMNH).

Further material examined: Guyana: Essequibo River, Moraballi Creek $\left(58^{\circ} 38^{\prime} \mathrm{W}, 6^{\circ} 24^{\prime} \mathrm{N}\right)$, female, 9.9.1929, leg. Oxford Univ. Expedition (BMNH); French Guyana: Coralie $\left(52^{\circ} 21.38^{\prime} \mathrm{W}, 4^{\circ} 30.41^{\prime} \mathrm{N}\right)$, male, 15.11.2011, leg. T. Struyve (UIC); Suriname: Marowijne, Palumenu $\left(55^{\circ} 26.18^{\prime} \mathrm{W}, 3^{\circ} 20.56^{\prime} \mathrm{N}\right), 160 \mathrm{~m}$ elevation, collected by flight intercept trap, female, 5.-9.7.1999, leg. Z.H. Falin \& D. Konoe, SUR1F99 185 (KNHM).

Diagnosis: O. guiananus closely resembles O. longipunctatus and $O$. breviceps in the shape and punctation of the pronotum and the rectangular shoulders of the elytra. $O$. breviceps is distinctly larger and the digits on outer edge of protibia shorter. Compared to O. longipunctatus, the colouration is black, whereas it is light brown in O. longipunctatus. The pronotal punctures are not elongate and the surface is without microsculpture and without iridescent shine.

Description: Length: $5.3 \mathrm{~mm}$. Colouration: black, posterior edge of pronotum reddish, elytra dark red, antennae and legs lighter red.

Head: $0.65 \mathrm{~mm}$ long, 1.00 wide; front margin of clypeus with wide emargination and without teeth at outer angles; 
eyes as long as temples; with dense punctation, except moderately wide midline and large area at base of antennae; distance between punctures much shorter than diameter of punctures; each puncture with short yellow seta; without microsculpture, surface polished and shiny. Antennae with first antennomere as long as three following antennomeres, second antennomere globular, third shorter than second, antennomeres 4 to 6 increasing in width, sixth wider than long; antennomeres 7 to 10 distinctly larger than preceding antennomeres and wider than long. Pronotum: $0.90 \mathrm{~mm}$ long, $1.00 \mathrm{~mm}$ wide; widest at anterior edge; evenly convergent to posterior edge; lateral and posterior margin narrow; punctation conspicuously sparser than on head; interstices between punctures as wide as diameter of punctures; wide midline impunctate; each puncture with short yellow seta pointing posteriad and partly curved; sparse micro-punctation between coarse punctation; surface polished and shiny.

Elytra: $1.00 \mathrm{~mm}$ long, $1.00 \mathrm{~mm}$ wide; with coriaceous ground-sculpture, large dense punctation hardly visible in deep ground-sculpture; each puncture with short yellow seta pointing posteriad; surface less shiny than on pronotum.

Abdomen with dense punctation; each puncture with long yellow seta; surface polished.

Protibia: $0.59 \mathrm{~mm}$ long, $0.14 \mathrm{~mm}$ wide; with 7 spines, apical 5 spines inserted on moderately long digits; WLR: 0.57 ; in posterior aspect, comb of inner emargination totally visible; on anterior face with row of 7 long setae; posterior face sparsely covered by long yellow setae.

Aedeagus angulate in nearly rectangular angle; apical lobe thick at base; then suddenly narrowed to nearly acute apex; apical lobe laterally and apically with groups of three sensillae and at inner edge with row of numerous sensillae.

\section{Osoriellus longipunctatus $\mathrm{n} . \mathrm{sp}$.}

(Figs 38A-C, 42A)

Type material: Holotype, male: Brazil: Pará, Ilha de Mosqueiro $\left(48^{\circ} 22^{\prime} \mathrm{W}, 1^{\circ} 09^{\prime} \mathrm{S}\right)$, soil litter layer in primary forest, 20.6.1974, leg. R.T. Schuh (AMNH).

Paratypes: Brazil: 5 males, 5 females with same data as holotype (AMNH, UIC, INPA); Pará, Belém, IPEAN, primary terra firme forest, Plot \#5, 3 females, 2 male, 6.6.1973, leg. R.T. Schuh (AMNH, UIC); Belém, 2 males, 30.5.-6.6.1973, leg. R.T. Schuh (AMNH).

Diagnosis: The species is characterised by the elongate punctures and the iridescent shine of the pronotum. It can be confused with O. guiananus concerning the size, the trapezoidal shape of the pronotum, and the digitate outer edge of the protibia. But the pronotal surface of O. guiananus is polished and shiny. A trapezeoidal shape of the pronotum is also found in O. breviceps, but $O$. breviceps is larger, the clypus is not emarginate and the posterior pronotal angles are obtuse and not nearly rectangular such as in $O$. longipunctatus.
Description: Length: $5.2 \mathrm{~mm}$. Colouration: Dark brown; elytra, abdomen, legs, and antennae lighter brown.

Head: $0.65 \mathrm{~mm}$ long, $1.09 \mathrm{~mm}$ wide; eyes thick and prominent; twice as long as temples; sides of fore-head narrowed to acute anterior angles of clypeus in sinuate curve; on inner side of anterior angles with second short acute teeth; anterior edge emarginate; punctation dense; nearly coriaceous; punctures elongate; at least punctures of clypeus with very short yellow setae; on supraocular area punctation still denser and with striae; few punctures with long setae; pair of punctures on clypeus and on vertex close to neck with long setae; surface with weak and extremely dense microsculpture; surface with iridesence shine.

Antennae slightly longer than head; second antennomere oval, third conical and as long as second; antennomeres four to six nearly equally wide and quadrate; following antennomeres distinctly wider, but also nearly quadrate.

Pronotum: $1.06 \mathrm{~mm}$ long, $1.17 \mathrm{~mm}$ wide; widest at anterior angles; anterior angles very shortly produced to acute teeth; sides evenly narrowed to posterior angles; in front of posterior angles shortly emarginate; shape nearly trapezoidal; posterior angles still obtuse, but nearly rectangular; lateral margin fine in anterior half; thicker and widened to posterior angles; punctation dense and deep; punctures elongate; adjacent to midline, partly coriaceous; very narrow midline in posterior half and pair of small areas in posterior half impunctate; on average, interstices between punctures as wide as half of diameter of punctures or slightly wider; punctures without setae; between normal coarse punctures with sparse micro-punctation; surface with iridesence shine, but less distinct than on head.

Elytra: $1.28 \mathrm{~mm}$ long, $1.19 \mathrm{~mm}$ wide, sides nearly parallel; shoulders nearly rectangular; punctation indistinct; hardly visible in deep coriaceous ground-sculpture; punctures in irregular rows.

Abdomen with dense setiferous punctation; abdominal tergites III-VI with narrow impunctate midline; abdominal tergites VII and VIII with elongate punctures; without microsculpture; surface shiny.

Protibia: $0.52 \mathrm{~mm}$ long, $0.13 \mathrm{~mm}$ wide; outer edge with 7 spines; apical spines inserting on long teeth; WLR: 0.50; inner emargination with comb visible throughout its total length; posterior face sparsely covered by long yellow setae.

Aedeagus with thick apical lobe at base; then suddenly narrowed to shortly rounded apex; apical lobe laterally with six sensillae and at inner edge with row of numerous sensillae.

Etymology: The specific name longipunctatus is a combination of the epithet longus meaning long and punctatus meaning punctate and refers to the elongate punctation of the pronotum. 


\section{Osoriellus macrops $\mathrm{n}$. sp.}

(Figs 35A-C, 41E)

Type material: Holotype, male: Brazil: Amazonas, Reserva Ducke (59 $\left.55^{\prime} \mathrm{W}, 2^{\circ} 52^{\prime} \mathrm{S}\right), 26 \mathrm{~km}$ NE Manaus, flight intercept trap, 1995-1996 (BMNH).

Paratype: Brazil: Amazonas, Manaus, female, 26.10.1955, leg. Elias \& Roppa (UIC).

Diagnosis: The species mostly resembles O. solidus and can be hardly differentiated from that species. In contrast to O. solidus, the microsculpture of the posterior tergites is dense and distinct and the surface is matt. Additionally, remains of isodiametric microsculpture are found on the pronotum in O. macrops, but not in O. solidus.

Description: Length: $7.0 \mathrm{~mm}$. Colouration: Black; legs and antennae brown.

Head: $0.91 \mathrm{~mm}$ long, $1.59 \mathrm{~mm}$ wide; eyes thick and distinctly prominent; approximately 1.5 times as long as temples; sides of fore-head narrowed to anterior angles in deep sinuate curve; anterior edge of clypeus even; punctation coarse and moderately dense; large punctures without setae, except few punctures on clypeus, two on vertex and few on supraocular area; partly coriaceous; interstices between punctures irregularly wide; on average, much smaller than diameter of punctures; without impunctate midline; close to neck with narrow transverse impunctate area; without microsculpture; surface shiny.

Antennae slightly shorter than head and half of pronotum combined; second antennomere oval; slightly thicker and longer than conical third antennomere; following antennomeres increasing in width; fourth antennomere slightly longer than wide, fifth quadrate and following antennomeres slightly wider than long.

Pronotum: $1.42 \mathrm{~mm}$ long, $1.67 \mathrm{~mm}$ wide; widest at anterior angles; anterior angles rectangular; sides narrowed to posterior angles in even slightly convex curve; posterior angles obtuse; smoothly rounded; lateral margin fine in anterior half; slightly widened to posterior angles; in dorsal aspect, covered close to anterior angles; punctation coarse and moderately dense; without setae; impunctate midline in anterior half extremely narrow; in posterior half slightly wider; on average, interstices between punctures slightly shorter than diameter of punctures; between coarse punctation with dense micro-punctation; isodiametric microsculpture weak; hardly visible; surface shiny. Elytra: $1.77 \mathrm{~mm}$ long, $1.76 \mathrm{~mm}$ wide; shoulders obtuse, but nearly rectangular; sides slightly widened to posterior third; punctation approximately as dense and coarse as on pronotum; without setae; coriaceous ground-sculpture weak; less deep than punctures.

Abdomen with dense and moderately deep punctation; punctures without setae; punctation on distal tergites denser than on apical tergites; punctures on tergites VII and VIII elongate; microsculpture on apical tergites netlike and weak; microsculpture on tergites VII and VIII densely elongate and deep; apical tergites shiny; distal tergites matt.

Protibia: $0.79 \mathrm{~mm}$ long, $0.28 \mathrm{~mm}$ wide; outer edge with 9 spines; apical spines on long digits; WLR: 0.49; in posterior aspect, comb of inner emargination totally visible; posterior face sparsely covered by long yellow setae; on average, setae half as long as protibial width or slightly longer.

Aedeagus with long and slender apical lobe; apical lobe much longer than basal lobe; ending in shortly rounded apex; inner edge of apical lobe with sparse row of sensillae.

Etymology: The specific name is a combination of the epithet macro meaning large and ops meaning eye and refers to the large eyes of the species.

\section{Osoriellus melancholicus n. sp. (Figs 36A-C, 41F)}

Type material: Holotype, male: Peru: Dept. Loreto, Campamento San Jacinto $\left(75^{\circ} 51.77^{\prime} \mathrm{W}, 2^{\circ} 18.75^{\prime} \mathrm{S}\right)$, collected by berlese extraction at Qd. 22, 175-215 m elevation, 2.7.1993, leg. R. Leschen (KNHM).

Paratypes: Peru: 2 females with same data as holotype, but collected from flowerfall by berlese extraction and at 11.7.1993 (KNHM, UIC); Dept. Loreto, $1.5 \mathrm{~km} \mathrm{~N}$ Teniente Lopez $\left(76^{\circ} 06.92^{\prime} \mathrm{W}, 2^{\circ} 35.66\right.$ 'S $), 210-240 \mathrm{~m}$ elevation, collected by flight intercept trap, female, 24.7.1993, leg. R. Leschen (KNHM); Brazil: Amazonas, Manaus, $26 \mathrm{~km} \mathrm{~N}$ of Manaus, Reserva Ducke, collected by flight intercept trap, male, 1995-1996 (BNHM).

Diagnosis: Concerning the pronotal microsculpture, O. melancholicus can be confused with O. breviceps, but the shape of the pronotum is distinctly different. Additionally, the anterior edge of the clypeus is emarginate and not even as in O. breviceps.

Description: Length: 6.3 long. Colouration: Black; legs and antennae brown.

Head: $0.81 \mathrm{~mm}$ long, $1.24 \mathrm{~mm}$ wide; eyes slightly prominent; nearly twice as long as temples; sides of fore-head narrowed to anterior angles in smooth sinuate curve; anterior angles obtuse; anterior edge of clypeus deeply emarginate; punctation deep; central area on clypeus and area at base of antennae impunctate; on clypeus, interstices between punctures at least as wide as diameter of punctures; on vertex with denser punctation; centrally, interstices between punctures half as wide as diameter of punctures; laterally, interstices between punctures still shorter, partly coriaceous; punctures on clypeus with short yellow setae; punctures on vertex without setae, except one pair of setiferous punctures in centre close to neck and several setiferous punctures on supraocular area; without microsculpture; surface shiny. 
Antennae as long as head and half of pronotum combined; second antennomere oval and as long as conical third; antennomeres four and five as wide as preceding antennomeres; width of following antennomeres increasing, but each antennomere approximately quadrate.

Pronotum: $1.24 \mathrm{~mm}$ long, $1.37 \mathrm{~mm}$ wide; widest shortly behind anterior angles; anterior angles obtuse and rounded; evenly narrowed to posterior angles; shortly in front of posterior angles slightly emarginate; posterior angles nearly rectangular and slightly produced laterad; lateral margin fine in anterior half; widened to posterior angles; in dorsal aspect; covered shortly close to anterior angles; deep and coarse punctation irregularly dense; near midline denser than laterally; impunctate midline narrow in anterior half and widened in posterior half; close to midline punctation nearly coriaceous; on lateral disc, interstices between punctures as wide as diameter of punctures or closer; punctures without setae; between normal coarse punctures with dense micro-punctation; very weak longitudinal reticulate microsculpture; surface slightly shiny.

Elytra: $1.51 \mathrm{~mm}$ long, $1.44 \mathrm{~mm}$ wide; shoulders shortly rounded; sides nearly parallel; punctation slightly finer than on pronotum; in irregular rows; ground sculpture deep; surface slightly shiny.

Abdomen with dense setiferous punctation; narrow midline impunctate; punctures partly granulate and on segment VII and VIII partly elongate; irregular microsculpture very weak; surface slightly shiny.

Protibia: $0.77 \mathrm{~mm}$ long, $0.20 \mathrm{~mm}$ wide; slender; with 7 spines on outer edge; apical spines inserted on long teeth; WLR: 0.36; in posterior aspect, inner emargination with comb visible throughout its total length; posterior face sparsely covered by long yellow setae.

Aedaegus thick; with basal lobe and apical lobe approximately equally long; apical lobe thick at base; then suddenly narrowed to thin apex; inner edge of apical lobe with dense row of sensillae; apical third of inner edge without sensillae.

Etymology: The specific name melancholicus derived from the same Latin word meaning dark and refers to the black colouration.

\section{Osoriellus silvaticus $\mathrm{n}$. sp.}

(Figs 39A-C, 42B)

Type material: Holotype, male: Ecuador: Orellana, Payamino Research Station ( $\left.77^{\circ} 17.29^{\prime} \mathrm{W}, 0^{\circ} 26.36^{\prime} \mathrm{S}\right)$, $300 \mathrm{~m}$ elevation, tropical rainforst, collected by flight intercept trap, 30.7.-12.8.2007, leg. Gillett (BMNH).

Diagnosis: The species resembles O.diversus of the O.-guiananus-group. It has no setiferous punctation, but only few punctures with setae. In this respect, it resembles species of the genus Osorius; but the posterior face of the protibia carries no spines. A similar shape of the pronotum with the slightly widened lateral margin in the posterior half is also found in some species of the remaining-species-group. O. silvaticus can be easily differentiated from these species by the absence of the setiferous punctation.

Description: Length: $6.9 \mathrm{~mm}$. Colouration: Black, legs and antennnae dark brown.

Head: $0.78 \mathrm{~mm}$ long, $1.20 \mathrm{~mm}$ wide; eyes prominent; small; slightly shorter than temples; sides of fore-head narrowed to teeth-like produced anterior angles in deep sinuate curve; between acute anterior angles, anterior edge of clypeus even; punctation not setiferous; punctures weak and sparse; interstices between punctures at least as wide as diameter of punctures; on both clypeus and vertex four setiferous punctures each; punctation on supraocular area denser and deeper; partly coriaceous; netlike microsculpture extremely weak and partly absent; surface of vertex shiny.

Antennae slightly longer than head; second antennomere oblong; third cornical and slightly longer than second; third antennomere 1.5 times as long as fourth; fourth to sixth antennomere slightly longer than wide; following antennomeres distinctly thicker than preceding antennomeres and approximately quadrate.

Pronotum: $1.16 \mathrm{~mm}$ long, $1.34 \mathrm{~mm}$ wide; widest at anterior angles; anterior angles produced to shorth acute teeth; sides evenly convergent to posterior angles; slightly sinuate in front of posterior angles; lateral margin fine in anterior half, slightly widened in posterior half; shape approximately trapezoidal; punctation not setiferous; deeper and denser than on head; on average, interstices between punctures slightly shorter than diameter of punctures; indistinct narrow midline impunctate; netlike microsculpture deeper than on head; surface slightly shiny.

Elytra: $1.45 \mathrm{~mm}$ long, $1.51 \mathrm{~mm}$ wide; widest in posterior third; rectangular shoulders sligthly rounded; punctation not setiferous; weak and dense; hardly visible in deep coriaceous ground-sculpture; surface matt.

Abdomen without punctation, but each segment dorsally with pair of setiferous punctures on each side of middle; netlike microsculpture distinct, but not deep; surface slightly shiny.

Protibia: $0.69 \mathrm{~mm}$ long, $0.27 \mathrm{~mm}$ wide; with 8 spines on outer edge; apical three spines inserted on long digits; WLR: 0.50 ; in posterior aspect, comb at inner emargination widely covered; posterior face sparsely covered by moderately long setae.

Aedeagus symmetric with evenly curved apical lobe; approximately as long as basal lobe; dorsal edge of apical lobe slightly sinuate at apex; group of three sensillae close to apex on lateral side; inner edge of apical lobe with row of numerous sensillae.

Etymology: The specific name derived from the same Latin word and means living in the forest. 
Osoriellus solidus (SHARP, 1876) new combination (Figs 34A-C, 41B)

Osorius solidus SHARP, 1876: 384

Type material examined: Brazil: Amazonas, São Paulo de Olivença (holotype partly destroyed in BMNH). shows no traces of microsculpture. The surface is totally polished and shiny.

Description: Length: $7.2 \mathrm{~mm}$. Colouration: Black; legs and antennae dark brown.

Head: $0.91 \mathrm{~mm}$ long, $1.33 \mathrm{~mm}$ wide; eyes slightly prominent; nearly 1.5 times as long as temples; fore-head narrowed to anterior edge in slight concave curve; ante-

\section{Key to the species}

1. Anterior edge of clypeus even, sides of pronotum evenly narrowed in smooth convex curve or shortly sinuate in front of posterior angles; posterior angles obtusely rounded.

Anterior edge of clypeus emarginate, sides of pronotum shortly sinuate in front of posterior angles; posterior angles approximately rectangular.

2. Large species of at least $7.0 \mathrm{~mm}$ length, eyes distinctly prominent, posterior angles of pronotum weakly developed..

Smaller species of $6.5 \mathrm{~mm}$ length or smaller; eyes less prominent.

3. Pronotum with distinct microsculpture and without micro-punctation, sides of pronotum straight with obtuse posterior angles.

O. breviceps (Notman, 1925)

- Pronotum without or with weak microsculpture and with micropunctation, sides of pronotum convex or slightly sinuate in front of posterior angles.

4. Pronotum without microsculpture, surface polished and shiny, sides not sinuate in front of posterior angles. ...... O. diversus n. sp.

Pronotum with weak microsculpture, surface moderately shiny, lateral margin widened in posterior half and sinuate in front of posterior angles.

O. silvaticus n. sp.

5. Pronotum with remains of weak isodiametric microsculpture, surface shiny.

O. macrops n. sp.

- Pronotum without traces of microsculpture, only with micro-punctation; surface polished and shiny. O. solidus (SHARP, 1876)

6. Colouration light brown, pronotum with dense elongate punctation, without micro-punctation.

O. longipunctatus n. sp.

- Colouration dark brown or black, pronotum with moderately dense punctation and with micro-punctation. ... 7

7. Smaller species of less than $5.5 \mathrm{~mm}$ length, pronotum without microsculpture, surface polished and shiny. O. guiananus (BERNHAUER, 1934)

Larger species of at least $6.0 \mathrm{~mm}$ length, pronotum with distinct microsculpture; surface matt or moderately shiny, not polished.

O. melancholicus $\mathrm{n}$. sp.

Further material examined: French Guiana: Roura, $39.4 \mathrm{~km}$ SSE $\left(52^{\circ} 08.26^{\prime} \mathrm{W}, 4^{\circ} 32.43^{\prime} \mathrm{N}\right), 270 \mathrm{~m}$ elevation, collected by flight intercept trap, 6 males, 5 females 29.5.10.6.1997, 23.-24.5.1997, leg. J. Ashe, R. Brooks (KNHM, UIC); $27.4 \mathrm{~km} \quad$ SSE $\left(52^{\circ} 13.25^{\prime} \mathrm{W}, 4^{\circ} 44.20^{\prime} \mathrm{N}\right), 280 \mathrm{~m}$ elevation, 4 male, 4 female, 25.-26.5.1997, 10.6.1997, leg. J. Ashe, R. Brooks (KNHM, UIC); $18.4 \mathrm{~km} \mathrm{SSE}$ $\left(52^{\circ} 13.25^{\prime} \mathrm{W}, 4^{\circ} 36.38^{\prime} \mathrm{N}\right), 240$ m elevation, 2 females, 29.5.10.6., leg. J. Ashe, R. Brooks (KNHM).

Diagnosis: O. solidus mostly resembles O. macrops in size, shape of pronotum and abdominal microsculpture. In contrast to O. macrops, the pronotum of O. solidus rior edge of clypeus even with slightly produced angles; punctures large and without setae; punctures mostly elongate and partly coriaceous; clypeus densely punctate; central vertex and area at base of antennae impunctate; supraocular area very densely and coriaceously punctate; vertex more sparsely punctate than clypeus und supraocular area; four setae on clypeus, four in transverse row close to neck, and few supraocular and preocular setae; without microsculpture; surface moderately shiny. Antennae slightly shorter than head and half of pronotum combined; second antennomere oval; longer than wide; third conical and as long as second; following antennomeres increasing in width; antennomeres four and five longer than wide; tenth antennomere nearly quadrate. 
Pronotum: $1.42 \mathrm{~mm}$ long, $1.55 \mathrm{~mm}$ wide; widest shortly behind anterior angles; evenly convergent to posterior angles in convex curve; lateral margin fine and slightly widened to posterior angles; in dorsal aspect, not visible close to anterior angles; punctation moderately large and dense; punctures without setae; smaller than on head and not elongate; on average, interstices between punctures between 1.5 times and two times as wide as diameter of punctures; narrow midline in posterior part impunctate; between normal coarse punctures with sparse micro-punctation; without microsculpture; surface shiny.

Elytra: $1.67 \mathrm{~mm}$ long, $1.85 \mathrm{~mm}$ wide; widest in posterior third; coriaceous ground-sculpture indistinct; punctures without setae and, on average, deeper and larger than on pronotum; surface moderately shiny.

Abdomen on tergites III to VI sparsely punctate and without microsculpture; tergites VII and VIII with dense elongate punctures similar as on head; with remains of fine elongate microsculpture.

Protibia: $0.79 \mathrm{~mm}$ long, $0.24 \mathrm{~mm}$ wide; slender; with 8 spines at outer edge; apical three spines inserted on long teeth; WLR: 0.48; in posterior aspect, inner emargination with comb visible throughout its total length; posterior face sparsely covered by long yellow setae.

Aedeagus with long slender apical lobe; apical lobe longer than basal lobe and smoothly curved to obtuse apex; row of sensillae on lateral face and on inner edge of apical lobe.

\section{Osoriellus-mrazi-group}

This group is defined by the unique combination of characters described for the single species.

\section{Description of the species}

Osoriellus mrazi n. sp.

(Figs 40A-D, 42B)

Type material: Holotype, male: Brazil: Såo Paulo, leg. Jaro K. Mraz (NMP).

Diagnosis: The species cannot be placed to one of the other groups. It is characterised by the normally coarse punctation of the pronotum, the short teeth at clypeal angles and the long digits of the protibia. It resembles to the species of the O.-guiananus- and the O.-laeviusculus-group concerning the absence of the pubescence of the fore-body. But compared to both groups, the eyes are not prominent and the pronotum is without dense microsculpture.
Description: Length: $6.4 \mathrm{~mm}$. Colouration: Black; legs and antennae brown.

Head: $0.97 \mathrm{~mm}$ long, $1.44 \mathrm{~mm}$ wide; eyes moderately large; not prominent; slightly longer than temples; sides of fore-head deeply emarginate; sides of clypeus parallel; anterior edge of clypeus with broadly produced angles; at inner side, adjacent to angles with acute triangular teeth; between teeth widely emarginate; punctation irregularly dense; not pubescent; small area on posterior vertex and large area at base of antennae impunctate; pair of indistinct impressions on posterior vertex and one indistinct impression in centre of anterior vertex; supraocular punctures partly granulate; on supraocular area with several striae; without microsculpture; surface polished and shiny.

Antennae slightly longer than head; second antennomere oblong; third antennomere conical and slightly longer than second; following antennomeres slightly longer than wide; tenth antennomere slightly wider than long.

Pronotum: $1.27 \mathrm{~mm}$ long, $1.52 \mathrm{~mm}$ wide; widest at anterior angles; anterior angles slightly produced to short teeth; sides convergent in even convex curve; posterior angles obtuse; lateral margin moderately fine; in dorsal aspect, visible throughout its total length; punctation deep and dense; without pubescence; irregularly dense; on average, interstices between punctures as wide as diameter of punctures; moderately wide midline impunctate; between coarse punctures with sparse micro-punctation; indistinct depressions on transverse line in middle; without microsculpture; surface polished and shiny.

Elytra: $1.44 \mathrm{~mm}$ long, $1.47 \mathrm{~mm}$ wide; with weak groundsculpture; punctures distinctly visible.

Abdomen with setiferous punctation; wide midline on tergites impunctate; with microsculpture; surface shiny. Protibia: $0.80 \mathrm{~mm}$ long; $0.26 \mathrm{~mm}$ wide; with 7 spines at outer edge; four apical spines inserted on long digits; WLR: 0.45; posterior face with few long setae.

Aedeagus with broad apical lobe; sinuate near apex; apex obtuse; inner edge at base with six sensillae.

Etymology: The specific name derived from the collector of the species, Jaro Mráz.

\section{Osoriellus-s. str.-group}

The species group is defined by the characters described by FAGEL (1959) for the genus Osoriellus: no digits at the outer edge of the protibia, narrow lateral margin of the pronotum, sides of the pronotum evenly curved from anterior to posterior angles and asymmetric aedeagus with lateral opening. In contrast to Fagel's describtion, the species with short apical digits at the outer edge of the protibia are also placed into this group. All species have a setiferous punctation. The size ranges from small to very large species. 


\section{Description of species}

\section{Osoriellus argentinus (BeRnHAUER, 1911) new combination}

(Figs 77A-C, 99D)

Osorius argentinus BERNHAUER, 1911: 403

O. acupunctus BERNHAUER, 1933, 332 new synonymy

O. ogloblini BERNHAUER, 1933: 332 new synonymy

Type material examined: Argentina: Missiones, male without further data, leg. C. Bruch (holotype FMNH); female leg. Ogloblin (as O. ogloblini in FMNH); Buenos Aires, female, 15.12.1899, leg. Silvestri (as O. acupunctus in FMNH).

Further material examined: Paraguay: Villarica $\left(25^{\circ} 45^{\prime} \mathrm{S}\right.$, $\left.56^{\circ} 25^{\prime} \mathrm{W}\right), 125 \mathrm{~m}$ elevation, 16 specimens from July, August, September, October, November, January and March 1937, leg. F. Schade (AMNH, UIC); 1 male without further data, identified by Bernhauer as O. acupunctus, 3 females, leg. Drake identified as O. frater by Bernhauer (SDEI); Brazil: Pará, Jacaréacanga, at light, male, Jan. 1970, leg. F.R. Barbosa (AMNH).

Diagnosis: The species highly resembles O. mexicanus and O. brevipennis in size and shape of the pronotum. It can be differentiated from O. mexicanus by the presence of at least remains of microsculpture on the head. In contrast to O. brevipennis, the shape of the pronotum is less triangular. Bernhauer (1933) described O. acupunctus and O. ogloblini considering the nearly lacking microsculpture of the head and the deeper punctures on the elytra. Unfortunately, the type specimens of O. ogloblini and O. acupunctus are females and, therefore, a study of the aedegaus was not possible. Within the large number of specimens in the AMNH the microsculpture of the head varies extremely from very deep ground-sculpture with slightly shiny surface to nearly polished surface. Additionally, the microsculpture of the abdomen varies in the same way. Furthermore, the row of punctures along the impunctate midline of the pronotum is not a differentiating character between N. argentinus and N. ogloblini. I found no other characters to separate the species even between the aedeagi of the non-type O. acupunctus of SDEI and $O$. argentinus. Thus, the species described by BERNHAUER (1933) are within the variability of O. argentinus.

Description: Length: $5.3-6.0 \mathrm{~mm}$ long. Colouration: Black, antennae and legs brown.

Head: $0.75 \mathrm{~mm}$ long, $1.20 \mathrm{~mm}$ wide; eyes as long as temples; clypeus with short granules at angles, front edge of clypeus between lateral granules even; punctation distinct and dense; interstices between punctures as wide as diameter of punctures or slightly shorter; yellow setae of punctures pointing centrally; lateral punctures partly coriaceous and granulate; surface with dense and moder- ately deep isodiametric microsculpture; area at base of antennae polished without microsculpture.

Antennae with first antennomere as long as three following antennomeres; antennomeres 2 to 4 short and quadrate; antennomeres 7 to 10 distinctly wider and thicker than preceding antennomeres.

Pronotum: $1.20 \mathrm{~mm}$ long, $1.25 \mathrm{~mm}$ wide; widest at anterior angles; evenly convergent to posterior angles in slightly convex curve; posterior angles smoothly rounded; in dorsal aspect, fine lateral margin visible from anterior to the posterior angles; punctation coarse and dense; interstices between punctures less than half of diameter of punctures; wide midline impunctate; between coarse punctation with fine micro-punctation; without microsculpture except on lateral posterior part; surface shiny. Elytra: $1.30 \mathrm{~mm}$ long. $1.20 \mathrm{~mm}$ wide; setiferous punctation similar as on head; on average, interstices between punctures as wide as diameter of punctures; punctures moderately deep, but less deep than on pronotum; surface with weakly coriaceous ground-sculpture, surface moderately shiny.

Abdomen with distinct and dense setiferous punctation; with moderately deep netlike microsculpture; surface slightly shiny.

Protibia: $0.70 \mathrm{~mm}$ long, $0.29 \mathrm{~mm}$ wide; thick; nearly semi-circular; with 10 spines on outer edge; two apical spines inserted on short digits, WLR: 1.6; in posterior aspect, comb at inner emargination partly covered in middle; anterior face with longitudinal row of five yellow setae; posterior face densely covered by thick setae; setae approximately one third as long as protibial width.

Aedaegus with slender apical lobe; apical lobe evenly curved to shortly rounded apex; apical lobe with one lateral sensilla and group of 5 sensillae at base.

\section{Osoriellus ashei n. sp.}

(Figs 57A-C, 97B)

Type material: Holotype, male: Mexico: Veracruz, $2.5 \mathrm{~km}$ S. Jalapa $\left(96^{\circ} 54^{\prime} \mathrm{W}, 19^{\circ} 29^{\prime} \mathrm{N}\right), 1370 \mathrm{~m}$ elevation, ex. Sifted from leaf litter, 26.5.1991, leg. J.S. Ashe (KNHM).

Paratypes: Mexico: 2 males, 2 females with same data as holotype and 25.5.1991 (KNHM); $3 \mathrm{~km} \mathrm{~S}$. Jalapa, ex flight intercept trap, 1370 m elevation, 2 males, 26.5.1991, leg. J.S. Ashe (KNHM, UIC).

Diagnosis: Concerning the size and the punctation of the pronotum, the species is extremely similar to the species with irregular rows of the pronotal punctures, i.e. O. salvini, O. flaveolus, O. levyi, O. bicolor, and $O$. loksai. In particular, O. bicolor and O. loksai resemble $O$. ashe $i$ in the absence of the pronotal microsculpture and the smaller size than the other three species. Compared to O. bicolor and O. loksai, the pronotal punctation in $O$. ashei is denser and coarser. The aedeagi of the three species are also very similar, but the number of sensillae at the inner edge of the apical lobe is different. 
Description: Length: $3.4 \mathrm{~mm}$. Colouration: Reddish brown; front edge of head and legs reddish; antennae yellow.

Head: $0.48 \mathrm{~mm}$ long, $0.64 \mathrm{~mm}$ wide; eyes not prominent and as long as temples; fore-head narrowed in concave curve to front angles; anterior clypeal angles rectangular; setiferous punctation deep and irregularly dense; on average, interstices between punctures half as wide as diameter of punctures; on supraocular area and on midline impunctate or sparsely punctate; between setiferous punctures with micro-punctation; without microsculpture; surface polished and shiny.

Antennae as long as head and half of pronotum combined; second antennomere oblong and 1.5 times as long as conical third; antennomeres four to six as wide as or slightly wider than third; more or less quadrate; antennomeres seven to ten distinctly wider than preceding antennomeres and distinctly wider than long.

Pronotum: $0.65 \mathrm{~mm}$ long, $0.67 \mathrm{~mm}$ wide; widest at anterior angles; evenly convergent to obtusely rounded posterior angles; shape trapezoidal; lateral margin fine; in dorsal aspect, not visible close to anterior angles; setiferous punctures large and in irregular rows; within rows, interstices between punctures half as wide as diameter of punctures; between rows, interstices slightly wider; approximately 8 punctures per row; between setiferous punctures with sparse micro-punctation; without microsculpture; surface polished and shiny.

Elytra: $0.82 \mathrm{~mm}$ long, $0.69 \mathrm{~mm}$ wide; shoulders obtusely rounded; densely and coarsely punctate; setiferous punctation irregular on weakly coriaceous ground-sculpture; interstices between punctures half as wide as diameter of punctures; surface less shiny than on pronotum.

Abdomen with impunctate midline; on each side of midline with dense and deep setiferous punctation; interstices half as wide as diameter of punctures; surface polished and shiny.

Protibia: $0.40 \mathrm{~mm}$ long, $0.13 \mathrm{~mm}$ wide; with 8 spines at outer edge; apical spines inserted directly on outer edge; WLR: 6.7; in posterior aspect, comb at inner emargination covered in middle; posterior face covered by long and thick setae; setae at least half as long as protibial width. Aedeagus with continuously curved apical lobe ending in obtusely rounded apex; inner edge of apical lobe with 8 sensillae.

Etymology: The species is named in honour of its collector, Prof. Dr. J.S. Ashe, who unfortunately passed too early.

\section{Osoriellus asperatus n. sp.}

(Figs 67A-C, 95F)

Type material: Holotype, male: Brazil: Amazonas, Manaus, INPA/Smithsonian Reserve 2 (59 $50^{\prime} \mathrm{W}, 2^{\circ} 25^{\prime} \mathrm{S}$ ), leaf litter of terra firme forest, collected by Winkler method, male, January 1994, leg. R. Didham (BMNH).
Paratypes: Brazil: with same data as for holotype, 3 females, 1 male, January 1994, February 1994, March 1994 (BMNH, UIC); Reserva Ducke, $26 \mathrm{~km} \mathrm{NE}$ of Manaus, flight intercept trap, female, 1995-1996 (BMNH).

Diagnosis: The species is characterised by the dense coriaceous punctation of the pronotum that is so far unique in the Neotropical Osoriellus species.

Description: Length: $3.4 \mathrm{~mm}$. Colouration: Black, anterior half of elytra dark red.

Head: $0.43 \mathrm{~mm}$ long, $0.69 \mathrm{~mm}$ wide; eyes thick and distinctly prominent; nearly twice as long as temples; sides of fore-head convergent to anterior angles; not sinuate; anterior edge of clypeus even; extremely dense setiferous punctation deep and coariaceous; interstices between punctures less than one fifth as wide as diameter of punctures; yellow setae long; only small area at base of antennae impunctate.

Antennae slightly shorter than head and half of pronotum combined; second antennomere oval and distinctly thicker than third antennomere; 1.5 times as long as third antennomere; following antennomeres increasing in width; third and fourth antennomeres approximately quadrate; following antennomeres wider than long; eighth antennomere 1.5 times as wide as long; tenth antennomere only slightly wider than long; surface matt.

Pronotum: $0.67 \mathrm{~mm}$ long, $0.70 \mathrm{~mm}$ wide; widest near anterior angles; sides approximately parallel in anterior half; in posterior half, more strongly and evenly narrowed to posterior angles; slightly sinuate shortly in front of posterior angles; posterior angles nearly rectangular; lateral margin fine; in posterior half, slightly wider than in anterior half; in dorsal aspect, hardly visible in anterior half; extremely dense setiferous punctation deep and coarse; partly coriaceous; punctures larger than on head; interstices between punctures one fifth as wide as diameter of punctures; wide, parallel midline impunctate; yellow setae at least as long as three times of diameter of punctures; without microsculpture; surface matt.

Elytra: $0.78 \mathrm{~mm}$ long, $0.75 \mathrm{~mm}$ wide; widest near middle; shoulders nearly rectangular; setiferous punctation less dense than on head and pronotum, but also deep and coarse; on average, interstices between punctures as wide as half of diameter of punctures; on average, yellow setae as long as double diameter of punctures; coriaceous ground-sculpture weak; surface matt.

Abdomen as densely and deeply punctate as fore-body; surface matt.

Protibia: $0.34 \mathrm{~mm}$ long, $0.12 \mathrm{~mm}$ wide; with 7 long spines on outer edge; apical spines inserted on short and wide digits; WLR: 3.1; in posterior aspect, comb at inner emargination totally visible; posterior face with moderately dense setation; yellow setae approximately as long as half of width of protibia. 
Aedaegus with thick basal lobe and short and thick apical lobe; apical lobe narrowed to obtuse, widely rounded apex; on inner edge of apical lobe, one sensilla in apical third and four sensillae in basal third.

Etymology: The specific name derived from the same Latin word meaning coarse and refers to the coarse punctation of the species.

\section{Osoriellus bicolor $\mathrm{n} . \mathrm{sp}$.}

(Figs 60A-C, 97A)

Type material: Holotype, male: Peru: Huanuco, Panguana (7457'37"W, 9³7'9"S), Cocha, male, June-September 1975, leg. W. Hanagarth (UIC).

Paratypes: 2 males, 3 females with same data as holotype; 2 females, from same locality, but river margin, 6.5.1975 and 26.12.1975, leg. Hanagarth (BMNH, KNHM, UIC).

Diagnosis: The species is part of a group of small species that includes $O$. ashei, O. levyi, and O. loksai. They resemble in size and absence of the microsculpture on the pronotum. O. bicolor can be differentiated from $O$. ashei by the obtuse anterior angles of the pronotum and from $O$. loksai and O. levyi by the denser pronotal punctation.

Description: Length: $3.5 \mathrm{~mm}$. Colouration: Reddish; elytra and abdomen lighter red; elytra indistinctly blackish in posterior third; legs and antennae yellow.

Head: $0.53 \mathrm{~mm}$ long, $0.65 \mathrm{~mm}$ wide; eyes not prominent and short; temples as long as eyes; fore-head distinctly narrowed to front edge of clypeus; clypeal angles produced to minute granules; front edge even; setiferous punctation coarse and denser on vertex than on fore-head; on vertex partly coriaceous; interstices between punctures nearly as wide as diameter of punctures; laterally, interstices between punctures one-fourth as wide as diameter of punctures; on disc with impunctate midline; surface without microsculpture, polished; neck and temples with netlike deep microsculpture; behind eyes with transverse row of short yellow setae.

Antennae with flagellum as long as pronotum; second antennomere slightly thicker than following four antennomeres; apical five antennomeres distinctly thicker than basal five antennomeres of flagellum; more or less quadrate.

Pronotum: $0.65 \mathrm{~mm}$ long, $0.65 \mathrm{~mm}$ wide; widest at anterior angles; evenly narrowed from anterior to posterior angles; posterior angles smoothly rounded; lateral margin fine; in dorsal aspect, not visible in anterior third; setiferous punctation coarse and dense; punctures large; on average, distance between punctures slightly less than half of diameter of punctures; punctures in irregular longitudinal rows; on both sides of impunctate midline with longitudinal row of 6 to 8 punctures; without microsculpture, but with sparse micro-punctures; surface polished.
Elytra: $0.80 \mathrm{~mm}$ long, $0.70 \mathrm{~mm}$ wide; with 5 irregular longitudinal rows of coarse punctures; surface with indistinctly coriaceous ground sculpture; slightly shiny, but not polished.

Abdomen distinctly punctate; setiferous punctures coarse and dense; on average, distance between punctures as wide as one-fourth of diameter of punctures.

Protibia: $0.39 \mathrm{~mm}$ long, $0.12 \mathrm{~mm}$ wide; thick and nearly semicircular; 9 short spines at lateral edge; apical spines not inserted on digits; WLR: 3.5; in posterior aspect, comb at inner emargination partly covered; posterior face densely covered by thick, moderately long setae; on average, setae as long as one third of width of protbia.

Aedeagus rectangularly angulate; apical lobe as long as basal lobe.

Etymology: The specific name means two colours and refers to the colouration of the elytra with the lighter red colour of anterior half and darker colour of posterior half.

\section{Osoriellus boliviensis n. sp. \\ (Figs 68A-C, 98D)}

Type material: Holotype, male: Bolivia: Cochabamba, $67.5 \mathrm{~km}$ NE, Estacion Biol. Valle del Sajita $\left(64^{\circ} 47.52^{\prime} \mathrm{W}\right.$, $17^{\circ} 06.33^{\prime} S$, Univ. de San Simon, 300 m elevation, male, 7.-9.Feb.1999, leg. F. Genier, \#1Biol1G99041, collected by flight intercept trap (KNHM).

Paratype: Peru: Huanuco, Sta. Panguana (74 $56^{\prime} \mathrm{W}$, $\left.9^{\circ} 37^{\prime} \mathrm{S}\right)$, Rio Llullapichis, female, 11.-12.2008, leg. F. Wachtel (UIC).

Diagnosis: Concerning its size and absence of microsculpture on the pronotum, the species resembles $O$. minor and O. tuxtlae. It can be easily differentiated from these two species by the prominent eyes. Moreover, it differs from $O$. tuxtlae by the wider pronotum and elytra. The shape of the pronotum and the elytra are very similar to O. minor, but the pronotal punctation is distinctly sparser in O. boliviensis than in O. minor. In O. minor the interstices between the pronotal punctures are approximately as wide as the diameter of the punctures, whereas in $O$. boliviensis the interstices are nearly twice as wide as the diameter of the punctures.

Description: Length: $4.5 \mathrm{~mm}$. Colouration: Brown; elytra lighter reddish; legs and antennae lighter brown.

Head: $0.57 \mathrm{~mm}$ long, $0.94 \mathrm{~mm}$ wide; eyes distinctly prominent and longer than temples; sides of fore-head narrowed to anterior angles in concave curve; sides of clypeus nearly parallel; apical margin even without granules at angles; setiferous punctation dense and deep with wide impunctate midline; interstices between punctures slightly smaller than half of diameter of punctures; on supraocular area punctation still denser, coriaceous and with granulate punctures; without microsculpture; surface shiny. 
Antennae with flagellum as long as head and half of pronotum combined; with oblong second and conical third antennomere, both more or less quadrate; following antennomeres increasing in width, but all antennomeres more or less quadrate.

Pronotum: $0.93 \mathrm{~mm}$ long, $1.02 \mathrm{~mm}$ wide; widest at anterior angles; anterior angles not produced to teeth; smoothly convergent to posterior angles; posterior angles indistinct, obtuse; lateral margin in anterior half finer than in posterior half; in dorsal aspect, visible throughout its total length; setiferous punctation as deep, but sparser than on head; more or less equally dense on disc except wide impunctate midline; on average, distance between punctures approximately twice as wide as diameter of punctures; between normally coarse punctures with extremely fine micro-punctation; without microsculpture; surface polished and shiny.

Elytra: $0.98 \mathrm{~mm}$ long, $1.09 \mathrm{~mm}$ wide; with weak coriaceous ground-sculpture and weak setiferous punctation; punctures in irregular rows and hardly visible in ground sculpture.

Abdomen with dense and deep setiferous punctation; wide midline on tergite III to VIII impunctate; without or with weak remains of microsculpture; surface shiny, nearly polished.

Protibia: $0.50 \mathrm{~mm}$ long, $0.14 \mathrm{~mm}$ wide; slender; 8 long spines at outer edge; 3 apical spines inserted on short digits; WLR: 1.75; in posterior aspect, comb at inner emargination visible throughout its total length; posterior face with sparse setation.

Aedeagus with broad, slightly curved apical lobe; shortly narrowed in front of apex to obtuse apex.

Etymology: The specific name boliviensis refers to the country, where the species was collected.

\section{Osoriellus brevicornis (NoTMAN, 1920) new combination (Figs 53A, 96F)}

Osorius brevicornis Notman, 1920: 698

Type material examined: U.S.A.: Florida, Pensacola, female, 11.4.1914 (holotype in ANHM).

Diagnosis: The species resembles O. rugipennis concerning the overall shape of the pronotum and the microsculpture, but microsculpture is weaker than in O. rugipennis and the colouration is yellow and not dark brown. The most conspicuous character of O. brevicornis are the short antennae with the wide third and fourth antennomeres and, in particular, the short, transverse antennomeres five and six. Moreover, the following antennomeres are distinctly thicker forming an indistinct club. According to Notman (1920) the species occurred in southern U.S.A. and in northern Mexico, Colima, E. Chihuahua $\left(106^{\circ} 04.13 \mathrm{~W}, 28^{\circ} 29.30 \mathrm{~N}\right)$, leg. Conradt. This place is located at the periphery of Chihuahua city which is in northern Mexico and part of the Nearctic region. As it was not found in southern Mexico, the species is assumingly not part of the Neotropical fauna.

Description: Length: $4.0 \mathrm{~mm}$. Colouration: Head and abdomen brown, pronotum and elytra light red, legs and antennae yellow.

Head: $0.60 \mathrm{~mm}$ long, $0.80 \mathrm{~mm}$ wide; eyes large, but not prominent, as long as temples; disc with dense setiferous punctures except on wide midline and smaller spot at base of antennae; on average, interstices between punctures half as wide as diameter of punctures; surface with distinct netlike microsculpture, slightly shiny.

Antennae short, second antennomere oblong, longer than wide; third antennomere conical and distinctly shorter than second; fourth antennomere conical and still shorter than third; fifth and sixth antennomeres much wider than long, but distinctly smaller than following antennomeres; antennomeres seven to eleven much wider than preceding antennomeres; forming indistinct club.

Pronotum: $0.80 \mathrm{~mm}$ long, $0.85 \mathrm{~mm}$ wide; widest at anterior edge; evenly convergent in smooth curve to posterior angles; posterior edge two-third as wide as anterior edge, lateral and posterior margin fine; anterior edge not margined; with dense setiferous punctures, setae pointing to wide impunctate midline; on average, interstices between oblong punctures as long as longitudinal diameter of punctures; surface with netlike microsculpture; microsculpture slightly weaker than on head.

Elytra: $0.90 \mathrm{~mm}$ long, $0.90 \mathrm{~mm}$ wide; with deep coriaceous ground-sculpture and irregular rows of setiferous punctures, setae pointing to middle.

Abdomen with setiferous punctation dense and deep; setae pointing to middle.

Protibia: $0.43 \mathrm{~mm}$ long, $0.15 \mathrm{~mm}$ wide; with 8 spines at outer edge; apical 3 spines inserted on short digits; WLR: 1.75; anterior face with a row of 5 setiferous punctures; posterior face densely covered by long yellow setae. Aedeagus unknown.

\section{Osoriellus brevipennis (NoTMAN, 1925) new combination \\ (Figs 76A-C, 99C)}

Osorius brevipennis Notman, 1925: 7

Type material examined: U.S.A: Arizona, Fort Grant, 12.7. without year, leg. Hubbard \& Schwarz (holotype in USNHM).

Further material examined: America septentrionalis: syntype to O. latipes (ZMHB); Mexico: Mexico, Real de Arriba, $6300 \mathrm{ft}$. elevation, 13 specimens, 1.07.1932, leg. H.E. Hinton (AMNH); Mexico, 1 male, leg. Höge, 2 males, 4 females, coll. Kraatz, without more data (SDEI); Nicaragua: Rio San Juan, $60 \mathrm{~km}$ SE San Carlos, Refugio Bartola $\left(84^{\circ} 20.30^{\prime} \mathrm{W}, 10^{\circ} 58.40^{\prime} \mathrm{N}\right)$, ex. fruitfall, $100 \mathrm{~m}$ elevation, 
29.5.2002, leg. R. Brooks, Z. Falin, S. Chatzimanolis (UIC); Costa Rica: Prov. San José, La Caja, male, July 1938, leg. A. Bierig (BMNH); nr. Salitral, nr. San José, 1200 m elevation, under rocks at edge of stream, 1 male, 1 female, 14.2.1982 and 4.3.1982, leg. G. Kirby \& Speight (BMNH).

Diagnosis: The species is very similar to O. mexicanus and can be differentiated from that species by the microsculpture of the head and the extremely triangular shape of the pronotum.

Description: Length: $5.4 \mathrm{~mm}$. Colouration: Black; legs and antennae reddish; elytra red.

Head: $0.75 \mathrm{~mm}$ long, $1.1 \mathrm{~mm}$ wide; eyes not prominent; as long as temples; front edge of clypeus even without lateral teeth; setiferous punctures moderately dense; wide impunctate midline; laterally and anteriorly with denser granulate punctation; in particular, on supraocular area with dense granulate, partly striate punctures; at base of antennae with further large impunctate area; surface with dense and distinct isodiametric microsculpture, matt; without microsculpture except impunctate area at base of antennae; surface polished.

Antennae with second and third antennomere nearly similar in length; second antennomere oval; third conical; following antennomeres narrow and quadrate; antennomeres seven to eleven much wider than preceding antennomeres and slightly wider than long.

Pronotum: $1.00 \mathrm{~mm}$ long, $1.15 \mathrm{~mm}$ wide; widest at anterior edge; evenly convergent to posterior angles; lateral and posterior margin narrow; punctures large and dense; along impunctate midline with row of coriaceous punctures; between coarse punctation with sparse micropunctation; surface without microsculpture; polished.

Elytra: $1.15 \mathrm{~mm}$ long, $1.15 \mathrm{~mm}$ wide; with moderately deep coriaceous ground-sculpture; punctures large and dense, but slightly smaller than on pronotum; punctures in irregular rows.

Abdomen with dense and deep setiferous punctation; surface with distinct isodiametric microsculpture; matt.

Protibia: $0.79 \mathrm{~mm}$ long, $0.29 \mathrm{~mm}$ wide; thick, nearly semicircular; with 10 spines on outer edge; WLR: 2.0; in posterior aspect, comb at inner emargination partly covered; posterior face densly coverd by yellow setae.

Aedeagus elongate; apical lobe slender and slightly curved to moderately obtuse apex; one sensilla at inner edge of apical lobe.

\section{Osoriellus caliginosus n. sp.}

(Figs 93A-C, 96F)

Type material: Holotype, male: Bolivia: Santa Cruz Dept., $3.7 \mathrm{~km}$ SSE Buena Vista Hotel Flora y Fauna $\left(63^{\circ} 33.15^{\prime} \mathrm{W}, 17^{\circ} 29.95^{\prime} \mathrm{S}\right), 400-450 \mathrm{~m}$ elevation, primary forest, collected by pyrethrum fogg. log infested with Schizopora paradoxa fung., 8.11.2002, leg. R. Leschen, \#BOL1L02-048 (KNHM).
Paratypes: Bolivia: 2 males with data as holotype, but 3.-9.11.2002 and 2.-9.11.2002 in secondary forest, collected by flight intercept trap (KNHM, UIC).

Diagnosis: As in O.fumarius, the pronotal sides are slightly sinuate in front of the posterior angles. In the similarly sized O. verhaaghi, O. rougemonti, O. opacus and $O$. schwarzi, the pronotal sides are evenly narrowed in smooth curve from anterior to posterior angles. The two species O.fumarius and O. caliginosus are mainly differentiated by the aedeagus. In O. fumarius the apical lobe is thick and broad, whereas O. caligonosus has an acute apex.

Description: Length: 6.0 long. Colouration: Black; legs and antennae dark brown.

Head: $0.72 \mathrm{~mm}$ long, $1.19 \mathrm{~mm}$ wide; eyes large and prominent; more than twice as long as temples; sides of fore-head narrowed to anterior angles in smooth sinuate curve; anterior edge of clypeus even; setiferous punctation moderately deep and dense; midline, small area at base of antennae and transverse oval area close to neck impunctate; on average, interstices between punctures as wide as diameter of punctures; on supraocular area slightly denser, more coriaceous and partly granulate; isodiametric microsculpture dense and deep; surface matt.

Antennae slightly longer than head; second antennomere oval; slightly thicker and longer than short conical third antennomere; fourth to sixth antennomeres approximately equally wide and quadrate; following antennomeres distinctly wider, but also approximately quadrate; last antennomere only 1.5 times as long as wide.

Pronotum: $1.10 \mathrm{~mm}$ long, $1.28 \mathrm{~mm}$ wide; widest close to anterior angles; anterior angles rectangular; sides evenly convergent to posterior angles; posterior angles distinct and nearly rectangular, but obtuse and shortly rounded; lateral margin fine in anterior half; wider in posterior half; in dorsal aspect, covered close to anterior angles; setiferous punctation deeper, but sparser than on head; on average, interstices two to three times as wide as diameter of punctures; in row adjacent to impunctate midline, punctures much denser and partly coriaceous; small areas on lateral and posterior disc impunctate; netlike microsculpture weaker than on head and meshes more elongate; surface slightly shiny.

Elytra: $1.34 \mathrm{~mm}$ long, $1.28 \mathrm{~mm}$ wide; shoulders nearly rectangular; sides nearly parallel; setiferous punctation as dense as on pronotum, but less deep; in irregular rows; coriaceous ground-sculpture weak; surface moderately shiny.

Abdomen with dense and deep setiferous punctation; much denser than on fore-body; netlike microsculpture moderately deep, but dense; surface matt.

Protibia: $0.63 \mathrm{~mm}$ long, $0.22 \mathrm{~mm}$ wide; shape nearly semicircular; outer edge with 8 spines; without digits at apex; WLR: 4.0; in posterior aspect, comb at inner emargination partly covered in middle; posterior face densely covered by long yellow setae. 
Aedeagus angulate in nearly rectangular angle; apical lobe long and slender; apical lobe thicker at base; in apical third suddenly narrowed to slender nearly acute apex; apical lobe laterally with two sensillae; inner edge of apical lobe with dense row of sensillae.

Etymology: The specific name caliginosus derived from the same Latin word meaning dark and refers to the dark colouration.

\section{Osoriellus coriaceus $\mathrm{n} . \mathrm{sp}$}

(Figs 51A-C, 95F)

Type material: Holotype, male: Brazil: Bahia, Urucuca, Cerro Grande, primary Atlantic forest $\left(39^{\circ} 3.43^{\prime} \mathrm{W}\right.$, $\left.14^{\circ} 25.17^{\prime} \mathrm{S}\right), 120 \mathrm{~m}$ elevation, 28.1.1995, leg. D. Agosti (AMNH).

Paratypes: Brazil: 4 females with same data as holotype (AMNH, UIC).

Diagnosis: The species can be easily identified by the coriaceous punctation of the head that is unique in the similarly sized species of the Neotropical Osoriellus species.

Description: Length: 3.3 - 3.4 mm. Colouration: Black; legs and antennae reddish.

Head: $0.47 \mathrm{~mm}$ long, $0.68 \mathrm{~mm}$ wide; eyes slightly longer than temples and slightly prominent; sides of fore-head sinuate; anterior edge of clypeus slightly emarginate and each angle with short granule; setiferous punctation dense, coriaceous and striate; surface matt.

Antennae with second antennomere thick and oval; thicker than three following antennomeres; third antennomere conical and shorter than second; fourth to sixth antennomeres as wide as or slightly wider than third, but approximately quadrate; seventh to eleventh antennomeres much thicker than preceding antennomeres, but only slightly wider than long.

Pronotum: $0.65 \mathrm{~mm}$ long, $0.70 \mathrm{~mm}$ wide; widest at anterior angels; slightly convergent to smoothly rounded posterior angles; lateral margin narrow; in dorsal aspect, not visible in anterior fourth; setiferous punctation dense; punctures large; on average, interstices between punctures half as wide as diameter of punctures; narrow midline impunctate; without microsculpture; surface polished, but only slightly shiny, because of dense punctation.

Elytra: $0.83 \mathrm{~mm}$ long, $0.68 \mathrm{~mm}$ wide; with dense and deep ground-sculpture; dense punctation slightly visible in coriaceous ground-sculpture; surface matt.

Abdomen with dense setiferous punctation, but less dense than on elytra; narrow midline impunctate; surface polished and shiny.

Protibia: $0.43 \mathrm{~mm}$ long, $0.12 \mathrm{~mm}$ wide; at outer edge with 6 long spines; apical spines directly inserted on outer edge; WLR: 3.0; in posterior aspect, comb at inner emar- gination totally visible; posterior face densely covered by yellow setae.

Aedeagus with smoothly curved apical lobe; apex obtuse.

Etymology: The specific name refers to the dense coriaceous punctation of the head.

\section{Osoriellus coruscus n. sp.}

(Figs 45A-C, 95C)

Type material: Holotype, male: Brazil: Rio de Janeiro, Paulo a Virginia, 10.8.1958, leg. R. Arlé (377) (INPA). Paratype: Brazil: female with same data as holotype (UIC).

Diagnosis: The species resembles O. exiguus in size and shape of the pronotum. In addition to the differences mentioned below in the diagnosis of $O$. exiguus, the shape of the aedeagus slightly differs from that of O. exiguus. In $O$. coruscus the apical lobe is short and thick and the apex truncate, whereas it is elongate in $O$. exiguus.

Description: Length: $2.6 \mathrm{~mm}$. Colouration: Dark yellow; posterior margin of elytra light brown; legs and antennae light yellow.

Head: $0.35 \mathrm{~mm}$ long, $0.47 \mathrm{~mm}$ wide; eyes small; not prominent; temples twice as long as eyes; side of fore-head more or less evenly convergent to front angles of clypeus; angles of clypeus produced to short teeth; setiferous punctation of clypeus sparse; punctation of vertex much denser and deeper, but with wide impunctate midline; microsculpture weak; laterad deeper and denser; midline without microsculpture; surface shiny; supraocular area less shiny than vertex.

Antennae slightly longer than head; second antennomere thick and oblong; thicker than antennomeres 3 to 5; third antennomere conical; only half as long as second; fourth to fifth antennomeres approximately quadrate; sixth antennomere wider than long; following antennomeres distinctly wider than preceding antennomeres and increasing in width; 1.5 times as wide as long.

Pronotum: $0.45 \mathrm{~mm}$ long, $0.50 \mathrm{~mm}$ wide; widest at anterior angles; slightly narrowed to smoothly rounded posterior angles; lateral margin narrow; in dorsal aspect, not visible near anterior angles; setiferous punctation as deep and dense such as on posterior head; on average, interstices between punctures less than half as wide as diameter of punctures; without microsculpture; surface polished and shiny.

Elytra: $0.60 \mathrm{~mm}$ long, $0.50 \mathrm{~mm}$ wide; with coarse and deep setiferous punctation; ground-sculpture distinctly coriaceous and deep; punctation scarcely visible; surface matt. Abdomen with deep and coarse setiferous punctures; tergites without basal impression; punctation on segments VII and VIII slightly less dense than on preceding segments; anterior segments matt; segments VII and VIII slightly shiny. 
Protibia: $0.27 \mathrm{~mm}$ long, $0.07 \mathrm{~mm}$ wide; 8 long spines on outer edge; apical spines not inserted on digits; WLR: 2.0; in posterior aspect, comb of inner emargination totally visible; posterior face with sparse setation; setae approximately half as long as protibial width.

Aedeagus thick; with short and stout apex; apical lobe smoothly curved.

Etymology: The specific name coruscus derived from the same Latin word meaning shiny and refers to the shiny surface of the pronotum.

\section{Osoriellus crassus (SHARP, 1887) new combination (Figs 78A-C, 102A)}

Osorius crassus SHARp, 1887: 681

Type material examined: Guatemala: San Geronimo, Vera Paz, 1 female, leg. Champion (holotype in BMNH); Mexico: Corodva, 2 males, leg. Höge (syntypes in $\mathrm{BMNH}$.

Diagnosis: O. crassus is one of the largest species of the genus. Only $O$. sexpunctatus from the remaining-speciesgroup is of similar size, but can be easíly differentiated by the long digitate protibia. Compared to O. sexpunctatus, the microsculpture of the head is deeper and the punctation of the pronotum denser. It also resembles O. parcus, but $O$. parcus is slightly smaller and has a weaker microsculpture on the pronotum.

Description: Length: $7.8 \mathrm{~mm}$; Colouration: Black, legs and antennae brown.

Head: $1.00 \mathrm{~mm}$ long, $1.60 \mathrm{~mm}$ wide; eyes short and not prominent; temples 1.5 times as long as eyes; sides of fore-head smoothly sinuate to clypeal angles; front edge of clypeus on each side with two distinct granules; between granules smoothly emarginate; setiferous punctation large and dense; on average, interstices between punctures half as wide as diameter of punctures; wide longitudinal area at base of antennae without punctures; irregular midline also impunctate; supraocular punctures granulate and partly with longer setae; on clypeus and close to neck with pair of two longer setae; isodiametric microsculpture deep; surface slightly shiny.

Antennae with oblong second antennomere; nearly twice as long as wide; third antennomere conical and as long as second; antennomeres 4 and 5 quadrate and not wider than preceding antennomeres; following antennomeres distinctly wider; approximately quadrate.

Pronotum: $1.50 \mathrm{~mm}$ long, $1.52 \mathrm{~mm}$ wide; widest at anterior angles; anterior angles slightly produced to acute teeth; evenly convergent to obtusely rounded posterior angles; lateral and posterior margin fine; setiferous punctures large, but moderately dense; on average, interstices between punctures as wide as diameter of punctures; irregular row of 14 to 15 punctures adjacent to impunc- tate midline; netlike microsculpture extremely fine, surface nearly polished.

Elytra: $1.70 \mathrm{~mm}$ long, $1.80 \mathrm{~mm}$ wide; punctation as deep and dense as on pronotum; punctures in irregular rows of approximately 10 punctures per row; with distinct coriaceous ground-sculpture; surface matter than on pronotum, but slightly shiny than on head.

Abdomen with deep and dense setiferous punctures; punctation still denser than on head; with weak netlike microsculpture; surface slightly shiny.

Protibia $0.82 \mathrm{~mm}$ long, $0.32 \mathrm{~mm}$ wide; with 13 spines on outer edge; apical spines inserting on short digits; WLR: 1.33; in posterior aspect, comb at inner emargination partly covered in middle; posterior face densely covered by yellow setae.

Aedeagus with apical lobe rounded in smooth curve ending in obtuse apex; left side of apical lobe with numerous sensillae near inner edge; two sensillae near outer edge and another area of sensillae near apex.

\section{Osoriellus debilis (SHARP, 1887) new combination (Figs 73A-C, 100D)}

\section{Osorius debilis SHARP, 1887: 681}

Type material examined: Panama: Chiriqui, Volcan de Chiriqui, leg. Champion (syntype in BMNH).

Further material examined: Mexico: Chiapas, Union Juarez, NE slope Volcan Tacana, Rio de Finca Muxbal, from freshly cut stump, much sap, peeling bark, $1430 \mathrm{~m}$ elevation, 26.12.1975, leg. H. Frania (AMNH); Ruinas de Palenque, nr. Group IV, stump litter, 1 male, 1 female, 6.4.1971, leg. C. Alteri (AMNH); Palenque, Ruines, 3 specimens, 6.04.1974, C.H. Curran (AMNH); San Louis de Potosi, Sierra de la Abra, Sotano de la Tinaja, flood debris on mud, slope, $500 \mathrm{~m}$ from entrance, 2 males, 1 female, 18.2.1970, leg. J.A.L. Cook (AMNH); same location, but $500 \mathrm{~m}$ in cave, 16.3.1972, leg. J.A. Cook (AMNH); Veracruz, $34 \mathrm{~km} \mathrm{~N}$ of Maolinco, $1280 \mathrm{~m}$ elevation, 21.-22.4.1978, leg. Henry, Schaffner \& Schuh (AMNH); Nayarit, Tepic, 1 specimen, 7.08.1947, B. Malkin (AMNH); Chajul, Selva Lacandona, Rio Lacatun, swebt \& beaten, 1 specimen, 26.06.1996, leg. L.S. Mahunka (NMB); Oaxaca, Oaxaca City, stream bank in tropical forest (partly sifting), 9 specimens, 12.11. + 16.11.1989, leg. R. Baranowski (SMNH); Belize: Orange Walk Dist. Rio Bravo Conservation Area, La Milpa Field Station, flight interc., 1 specimen, 25.5.1997, leg. C.E. Carlton (KNHM); Guatemala: 1 male, leg. Conradt, without more data (SDEI); Honduras: Cortés, Parque Nacional Cusuco, $5 \mathrm{~km}$ N Buenos Aires (88 $13^{\prime} \mathrm{W}$, $\left.15^{\circ} 29^{\prime} \mathrm{N}\right)$, oak/pine cloud forest, Malaise trap, 1 female, 15.08.1995, leg. R. Cave (SMNH); El Paraiso, $6.9 \mathrm{~km} \mathrm{~W}$ Yuscarán, Cerro Montserrat $\left(86^{\circ} 24^{\prime} \mathrm{W}, 13^{\circ} 55^{\prime} \mathrm{N}\right)$, forest litter, $1760 \mathrm{~m}$ elevation, Berlese, 1 specimen, 27.7.1994, leg. R. Anderson (KNHM); Nicaragua: Matagalpa, 
6 km NW, Selva Negra, Fountain Youth Trail (8554.53'W, $\left.12^{\circ} 59.99 \mathrm{~N}\right), 1450 \mathrm{~m}$ elevation, flight interc., 1 specimen, 22.5.2002, leg. R.W. Brooks, Z. Falin, S. Chatzimanolis (KNHM); Costa Rica: Puntarenas, $35 \mathrm{~km}$ NE San Vito, nr. Las Alturas, trail to Echandi, $2000 \mathrm{~m}$ elevation, beyond trail marker, litter near stream, 13 males, 23 females, 19.3.1991, leg. L. Herman (AMNH); same location, but under bark of logs, female, 20.3.1991, leg. L. Herman (AMNH); 35 km NE San Vito, nr. Las Alturas, trail to Cerro Enchandi, $2200 \mathrm{~m}$ elevation, beyond trail marker 30, litter near stream, 2 females, 19.3.1991, leg. L. Herman (AMNH); Las Cruzes, Biol. Stat. $\left(82^{\circ} 57.58^{\prime} \mathrm{W}\right.$, $\left.8^{\circ} 47.14^{\prime} \mathrm{N}\right), 1330 \mathrm{~m}$ elevation, flight interc., 3 specimens, 28.5.-30.5.2004, 28.5.-31.5.2004, leg. J.S. Ashe, Z. Falin \& I. Hinojosa (KNHM); Altamira Biol. Stn. $\left(83^{\circ} 00.49^{\prime} \mathrm{W}, 8^{\circ} 56.17^{\prime} \mathrm{N}\right), 1510-1600 \mathrm{~m}$ elevation, flight interc., 4 specimens, 4.-7.6.2004, leg. J.S. Ashe, Z. Falin \& I. Hinojosa (KNHM); Las Alturas Biol Stn. $\left(82^{\circ} 50.01^{\prime} \mathrm{W}\right.$, $\left.8^{\circ} 56.17^{\prime} \mathrm{N}\right), 1660 \mathrm{~m}$ elevation, flight interc., 3 specimen, 3.6.2004, leg. J.S. Ashe, Z. Falin \& I. Hinojosa (KNHM); Rincon de Osa $\left(83^{\circ} 31.11^{\prime} \mathrm{W}, 8^{\circ} 41.14^{\prime} \mathrm{N}\right), 50 \mathrm{~m}$ elevation, flight interc., 1 specimen, 26.6.2001, leg. S. \& J. Peck (KNHM); Corcovado National Park, Sirena Stn. lower Ollas Trail $\left(83^{\circ} 35.22^{\prime} \mathrm{W}, 8^{\circ} 24.48^{\prime} \mathrm{N}\right), 5 \mathrm{~m}$ elevation, flight interc., 2 specimens, 24.-28.06.2000, leg. Z.H. Falin (KNHM); same location, but Rio Pavo Trail, flight interc., 3 specimens, 25.-28.6.2000, leg. Z.H. Falin (KNHM); Monteverde, Boehme House, pitfall trap, $1400 \mathrm{~m}$ elevation, 1 specimen, 24.5.1989, leg. J.S. Ashe, R. Leschen, R. Brooks (KNHM); same location, flight interc., 1 specimen, 31.5.1992, leg. M.E. Jameson (KNHM); Finca La Pacifica $\left(85^{\circ} 08^{\prime} \mathrm{W}, 10^{\circ} 27^{\prime} \mathrm{N}\right)$, dry forest leaf litter, $40 \mathrm{~m}$ elevation, 17.07.1988, leg. L. Longino (KNHM); Heredia, Puerto Viejo de Serapiqui, La Selva Biol. Station, female, 18.2.1985, leg. L. Herman (AMNH); Puerto Viejo, 3 km S, La Selva $\left(84^{\circ} 00^{\prime} \mathrm{W}, 10^{\circ} 25^{\prime} \mathrm{N}\right), 80 \mathrm{~m}$ elevation, flight interc., 1 specimen, 2.-15.6.1996, leg. S. Haase-Statz \& R. Hanley (KNHM); Finca Zurqui $\left(84^{\circ} 00.22^{\prime} \mathrm{W}, 10^{\circ} 02.57^{\prime} \mathrm{N}\right), 1490 \mathrm{~m}$ elevation, flight interc., 15.-23.11.2001, R.W. Brooks (KNHM); San José, female, leg. E. Schmidt (AMNH); $2.4 \mathrm{~km}$ ENE Sn Gerardo de Riva $\left(83^{\circ} 34.20^{\prime} \mathrm{W}, 9^{\circ} 28.47^{\prime} \mathrm{N}\right)$, $1700 \mathrm{~m}$ elevation, flight interc., 1 specimen, 11.6.2004, leg. J.S. Ashe, Z. Falin \& I. Hinojosa (KNHM); Cartago, Ref. Nac. de Faune Silvestre, $2.5 \mathrm{~km}$ E Stn. $\left(83^{\circ} 46.82^{\prime} \mathrm{W}\right.$, $\left.9^{\circ} 44.23^{\prime} \mathrm{N}\right), 1330 \mathrm{~m}$ elevation, flight interc., 1 specimen, 1.11.2001, leg. R.W. Brooks (KNHM); Panama: Colon, Parque Nacional Soberania, Pipeline Rd. km 6.1, flight intercept trap, 7 specimens, 7.6.1995, 7.-21.6.1995, leg. J.S. Ashe, R. Brooks (KMNH, UIC); same location, but Pipeline Rd. km 2.0, $\mathrm{km} \mathrm{5.3,} \mathrm{km} \mathrm{4.1,} 4$ specimens, 23.5., 15.5., 16.5., 18.-19.5., 27.5.1995, leg. J. Jolly, C. Chaboo (KNHM); Poterillo, female, 27.5.1934, Blackwelder coll (AMNH); Chiriqui, NW Volcan $\left(82^{\circ} 40.26^{\prime} \mathrm{W}\right.$, $\left.8^{\circ} 49.16^{\prime} \mathrm{N}\right)$, litter near stream, 1410 m elevation, 2 males, 2 females, 16.5., 17.5.2001, leg. L. Herman \& W. Opitz, (AMNH); Barro Colorado, by Berlese sample, 1 specimen, 1.11.1952, leg. J. Zatek (AMNH); Barro Colorado, 5 specimens, 1.12.1929, 19.12.1928, 23.12. + 25.12.1928, leg. C.H. Curran (AMNH); Barro Colorado, 1 specimen, 16.11.1930, F.G. Lutz (AMNH); Panama, Rd. to Cerra Campana, litter nr. stream, 1 specimen, 22.12.2001, leg. L. Herman (AMNH); Canal Zone, Ciricito, male, 13.3.1930, coll. R. Blackwelder (AMNH); Barro Colorado Isd. $\left(79^{\circ} 51^{\prime} \mathrm{W}, 9^{\circ} 11^{\prime} \mathrm{N}\right)$, flight interc., 9 specimens, 7.7., 1.8., 6.8., 11.8., 16.8., 1994, leg. D. Banks (KNHM); same location, 1 specimen, 27.7.2000, leg. S. Chatzimanolis (KNHM); La Fortuna, Continental Divide Trail $\left(82^{\circ} 12.0^{\prime} \mathrm{W}, 8^{\circ} 46.0^{\prime} \mathrm{N}\right)$, forest litter, Berlese, $1200 \mathrm{~m}$ elevation, 1 specimen, 9.6.1995, leg. R. Anderson (KNHM); Venezuela: Aragua, Ocumare, $2.5 \mathrm{~km} \mathrm{NE}\left(63^{\circ} 41.0^{\prime} \mathrm{W}\right.$, $\left.10^{\circ} 03.0^{\prime} \mathrm{N}\right)$, flight intercept trap, 1 specimen, 4.-18.7.1994, leg. T. Phillips (KNHM); Columbia: without further data, labelled as O. fulvipes (ZMHB); S. Am. Colombia, without further location, 3 females, 1937, leg. G. Dahl (SMNH); Ecuador: Pichincha, Maquipucuna Station, $45 \mathrm{~km}$ NW Quito, 1600-1650 m elevation, flight intercept trap, male, 13.-14.Apr.1990, leg. C. Carlton \& R. Adrave (KNHM).

Diagnosis: Concerning the shape of the pronotum, the species can be confused with O. schwarzi, O. rougemonti and related species. However, O. debilis is distinctly smaller. A few specimens of O. debilis were not longer than $4.9 \mathrm{~mm}$. It resembles $O$. trapezoides in size, but the shape of the pronotum in $O$. trapezoides is more convergent; whereas in $O$. debilis the pronotal sides are smoothly curved and nearly subparallel in the anterior half. Large specimens of the species are also similar to small specimens of O. schwarzi. In O. schwarzi the microsculpture of the pronotum is isodiametric, whereas in O. debilis it is more longitudinal. In addition, the apical lobe of the aedeagus of $O$. debilis is more slender and with a rectangular angle in the upper half. In O. schwarzi the apical lobe is longer and thicker.

Description: Length: 4.9 - $5.4 \mathrm{~mm}$. Colouration: Dark brown; elytra slightly lighter; legs and antennae reddish. Head: $0.75 \mathrm{~mm}$ long, $1.0 \mathrm{~mm}$ wide; eyes slightly prominent; front edge of clypeus even with short granules at each angle; with large, but weak setiferous punctures; clypeus and vertex more densely punctate; at base of antennae impunctate; very weak isodiametric microsculpture; surface nearly polished.

Antennae with oblong second antennomere; as long as conical third antennomere; fourth to sixth antennomeres nearly quadrate; approximately half as long as third; slightly increasing in width; antennomeres 7 to 10 distinctly wider than preceding antennomeres, but more or less quadrate.

Pronotum: $0.95 \mathrm{~mm}$ long, $1.05 \mathrm{~mm}$ wide; widest at anterior angles; slightly narrowed in anterior two-third; distinctly convergent in posterior third; lateral margin fine; in dorsal aspect close to anterior angles invisible; setiferous punctures large and deeper than on head; punctures partly in irregular rows and coriaceous; on average, interstices between punctures half as wide as diameter of punctures, but laterally and posteriorly with 
sparser punctation; wide impunctate midline; with weak netlike microsculpture; microsculpture more distinct than on head; surface less shiny than on pronotum.

Elytra: $1.25 \mathrm{~mm}$ long, $1.15 \mathrm{~mm}$ wide; with irregular deep setiferous punctation; punctures slightly visible in deep coriaceous ground-sculpture.

Abdomen with dense but fine setiferous punctation; netlike microsculpture fine; surface moderately shiny.

Protibia: $0.72 \mathrm{~mm}$ long, $0.27 \mathrm{~mm}$ wide; with 9 spines at outer edge; spines not inserting on digits; WLR: 6.0 ; comb of inner emargination visible throughout its total length; posterior face densely covered by long yellow setae.

Aedeagus with apical lobe slender and at base in one line with basal lobe; curved in nearly rectangular angle in apical half; ending in obtuse apex; inner edge of apical lobe with few sensillae.

\section{Osoriellus eggersi (BERNHAUER, 1904) new combination (Figs 62A-C, 97C)}

Osorius eggersi Bernhauer, 1904: 19

Osorius laeviceps Notman, 1925: 15 new synonymy

Type material examined: Saint Thomas: West Indies, $\left(64^{\circ} .45^{\prime} \mathrm{W}, 18^{\circ} 20^{\prime} \mathrm{N}\right)$ leg. Eggers (holotype of O. eggersi in FMNH); Puerto Rico: San Juan $\left(66^{\circ} 06^{\prime} \mathrm{W}, 18^{\circ} 24^{\prime} \mathrm{N}\right)$ female, 1.-5.7.1915, leg. Lutz and Mutchler (holotype of O. laeviceps in AMNH, \# F 4003d).

Further material examined: Cuba: Prov. Pinar del Rio, Sierra del Rosario, El Mulo $\left(83^{\circ} 20^{\prime} \mathrm{W}, 22^{\circ} 42^{\prime} \mathrm{N}\right)$, north. slope, T. caida, MNA, 400 m elevation, 1 female, 2 males, 1 female, 11.-15.10.2007, leg. A. Lozada \& A. Hdez (IES); El Mulo, southern. slope, under bark, MSB, $200 \mathrm{~m}$ elevation, 1 female, 16.10.2007, leg. A. Lozada (IES); El Solón $\left(83^{\circ} 20^{\prime} \mathrm{W}, 22^{\circ} 42^{\prime} \mathrm{N}\right), \mathrm{SSB}$, bajo corteza, southern slope, $200 \mathrm{~m}$ elevation, 1 female, 242.1.2008, leg. A. Lozada (IES); Artemisia, Cayajabos $\left(82^{\circ} 51^{\prime} \mathrm{W}, 22^{\circ} 51^{\prime} \mathrm{N}\right)$, Sierra del Rosario, 2 females, 14.2.1932, leg. A. Bierig (BMNH); Dominican Republic: Constanza, 7 miles W. Bonao, road to Constance $\left(70^{\circ} 44^{\prime} \mathrm{W}, 18^{\circ} 53 \mathrm{~N}\right), 5.8 .1991$, leg. L. Herman, collected in leaf litter near stream (AMNH); Jarabacoa, $6.5 \mathrm{mi}$ W, east slope below Hotel Montana, 27.06.1991, leg. L. Herman, collected litter near stream (AMNH); San Francisco de Macoris, Loma de Quita Espuela $\left(-70^{\circ} 14^{\prime} \mathrm{W}, 1^{\circ} 18^{\prime}\right), 24.07 .1991$, leg. L. Herman, collected litter near stream (AMNH); Haiti: Kenskoff $\left(72^{\circ} 17.13^{\prime} \mathrm{W}, 18^{\circ} 27.2 \mathrm{~N}\right)$, Massif de la Selle, 1 specimen, 12.11.1934, leg. Darlington (MCZ); Jamaica: Montego Bay $\left(77^{\circ} 55^{\prime}, 18^{\circ} 27^{\prime} \mathrm{N}\right)$, sifted, 1 specimen, 10.03 .1911 , leg. Grossbeck (AMNH); Mexico: San Luis Potosi, 12 km NW Naranjo, 400 m elevation, flight intercept trap, 5.7.1990, leg. J.S. Ashe, K.J. Ahn, R. Leschen (KNHM); Jamaica, leg. Cameron, without further data $(\mathrm{BMNH})$; Nicaragua: Matagalpa, 6 km NW, Selva Negra, Fountain of Youth trail $1400 \mathrm{~m}$ elevation, flight intercept trap, 1 male, 22.5.2002, R.W. Brooks, Z. Falin, S. Chatzimanolis (KNHM).
Diagnosis: O. eggersi mostly resembles O. humicola in size and punctation of the pronotum. Without dissection of the aedeagus both species cannot be separated. In $O$. eggersi, the outer edge of the apical lobe of the aedeagus is sinuate ending in an acute apex, whereas in O. humicola it is evenly curved ending in an obtuse apex. O. eggersi also resembles $O$. carinicollis from the remaining-speciesgroup, but $O$. carinicollis has a distinctly digitate protibia, it is slightly smaller and the punctation of the pronotum is slightly finer. O. eggersi seems to be variable concerning the punctation of the pronotum and the number of sensillae on the apical lobe of the aedeagus. The specimens from Jamaica show a denser pronotal punctation than the specimens from Cuba, St. Thomas, and the Dominican Republic and only two instead of three apical sensillae.

Description: Length: 3.7 - $3.8 \mathrm{~mm}$. Colouration: Brown; elytra slightly lighter; abdomen light brown; legs and antennae yellow.

Head: $0.55 \mathrm{~mm}$ long, $0.70 \mathrm{~mm}$ wide; fore-head slightly elongate; distance from eyes to front margin 1.5 times as long as temples; densely and distinctly punctate; interstices between setiferous punctures half as wide as diameter of punctures; small area on central clypeus and another area at base of antennae impunctate; seta pointing posteriorly; surface without microsculpture; polished and shiny.

Antennae with first antennomere as long as three following antennomeres; second antennomere oval and as long as conical third; antennomeres 4 to 6 small, approximately quadrate; antennomeres 7 to 10 distinctly thicker and wider than long.

Pronotum: $0.70 \mathrm{~mm}$ long, $0.75 \mathrm{~mm}$ wide; widest at anterior angles; evenly convergent to posterior angles; slight emargination in front of posterior angles; lateral margin fine; coarsely and densely punctate; interstices between setiferous punctures as on head, but punctures deeper; moderately wide midline impunctate; setae pointing posteriorly; between coarse punctation with sparse micro-punctation; surface without microsculpture, polished and shiny.

Elytra: $0.75 \mathrm{~mm}$ long, $0.75 \mathrm{~mm}$ wide; with coriaceous ground-sculpture and deep and dense setiferous punctation, punctures slightly visible in coarse groundsculpture; yellow setae pointing posteriorly; surface less shiny than on pronotum.

Abdomen with even denser setiferous punctation than on pronotum, but punctures finer; surface with weak netlike microsculpture; less shiny than on pronotum.

Protibia $0.44 \mathrm{~mm}$ long, $0.14 \mathrm{~mm}$ wide; with 9 long spines at outer edge; apical spines on short digits; WLR: 2.5; in posterior aspect, comb of inner emargination visible throughout its total length; posterior face densely covered by long yellow setae.

Aedeagus rectangularly angulate; upper edge of apical lobe sinuate ending in acute apex; inner edge of apical lobe with two groups of sensillae. 
Osoriellus exiguus (Notman, 1925) new combination (Figs 43A-C, 94A)

Osorius exiguus Notman, 1925: 16

Type material examined: Cuba: Cayamas $\left(80^{\circ} 34^{\prime} \mathrm{W}\right.$, $22^{\circ} 16^{\prime} \mathrm{N}$ ), male, leg. E. Schwarz (holotype in NHMW).

Further material examined: Cuba: Prov. Granma, PN Turquino, on trail up to ca. $0.5 \mathrm{~km} \mathrm{~S}$ (by air) from La Platica $\left(76^{\circ} 53.3^{\prime} \mathrm{W}, 20^{\circ} 0.5^{\prime} \mathrm{N}\right), 920 \mathrm{~m}$ elevation, sifting of leaf litter and decaying wood in the secondary forest with many tree ferns and rich understory vegetation with meny ferns, 3 males, 7 females, 23.-27.06.2012, leg. DelerHernández \& Fikáček, \#MF20 (NMP, UIC); same region, saddle below La Mariposa, ca. $0.8 \mathrm{~km}$ SE La Platica (by air) $\left(76^{\circ} 52.9^{\prime} \mathrm{W}, 20^{\circ} 0.5 \mathrm{~N}\right), 1050 \mathrm{~m}$ elevation, sifting of leaf litter and decaying wood in the low secondary evergreen forest with rather rich understory vegetation and many roots, 4 males, 4 females, 24.06.2012, leg. Deler-Hernández \& Fikáček, \# MF22 (NMP); same region, slope below Pico Naranjo ca. $0.4 \mathrm{~km} \mathrm{~N}$ La Platica (by air) $\left(76^{\circ} 53.3^{\prime} \mathrm{W}\right.$, $\left.20^{\circ} 0.9^{\prime} \mathrm{N}\right), 950 \mathrm{~m}$ elevation, sifting of rather dry leaf litter and decaying wood in the secondary bushes with thin litter layer and rather rich understory (moss, grasses), 1 female, 24.06.2012, leg. Deler-Hernández \& Fikáček, \# MF23 (NMP); Belize: Cayo, Las Cuevas Research Station $\left(88^{\circ} 58.24^{\prime} \mathrm{W}, 16^{\circ} 44.00^{\prime} \mathrm{N}\right), 550$ elevation, flight intercept trap, 3 males, 3 females, 22.-26.5.2000, 18.-21.5.2000, 27.-31.5.2000, female, sifted under rotten log, 22.5.2000, leg. M. Caterino (BMNH); Costa Rica: Puerto Viejo, $3 \mathrm{~km}$ S, La Selva Biol. Stn., female, 16.04.1988, leg. Hespenheide (KNHM).

Diagnosis: O. exiguus is one of the smallest species of the genus and darker in colour than the other small species, i.e. O. coruscus. In O. exiguus the head is dark brown in cotrast to the light brown remaining body, whereas O. coruscus is totally yellow to light brown. In contrast to $O$. coruscus, the apical margin of the clypeus is even and angles without granules. The species also resembles O. indescriptus and without dissecting of the aedeagus the two species cannot be certainly identified. The punctation of the pronotum in O. indescriptus is slightly deeper and denser than in O. exiguus and colouration is darker. The aedeagus of $O$. indescriptus has a thick, nearly triangular apical lobe, whereas the apical lobe of O. exiguus is slender.

Description: Length: $2.5 \mathrm{~mm}$. Colouration: Light red; head brown; elytra, legs and antennae yellow; posterior margin of elytra dark.

Head: $0.42 \mathrm{~mm}$ long, $0.56 \mathrm{~mm}$ wide; eyes small; temples as long as eyes; apical edge of clypeus even; setiferous punctation on disc distinct and dense; wide midline and area at base of antennae impunctate; punctation of clypeus less dense; on clypeus, interstices between punctures at least as wide as diameter of punctures; setae pointing to middle; on vertex, interstices between punctures half as wide as diameter of punctures; surface without microsculpture, shiny.

Antennae short and stout; slightly longer than head; second antennomere thick and oval, nearly as thick as first antennomere; third and fourth antennomeres distinctly smaller than second; fourth and fifth antennomeres quadrate; following two antennomeres two times wider than long; last four antennomeres distinctly thicker than preceding antennomeres, but only slightly wider than long.

Pronotum: $0.52 \mathrm{~mm}$ long, $0.57 \mathrm{~mm}$ wide; widest at anterior angles; evenly narrowed to posterior edge; posterior edge smoothly rounded; setiferous punctation large and dense; interstices between punctures less than half as wide as diameter of punctures; wide impunctate midline; setae of punctures pointing to middle; surface without microsculpture, polished.

Elytra: $0.61 \mathrm{~mm}$ long, $0.56 \mathrm{~mm}$ wide; with coriaceous ground-sculpture; punctures slightly visible between coarse ground-sculpture.

Abdomen densely and coarsely punctate; setae of punctures pointing posteriorly; without microsculpture, surface shiny.

Protibia: $0.32 \mathrm{~mm}$ long, $0.09 \mathrm{~mm}$ wide; with 8 spines at outer edge; apically without digits; WLR: 3.0 ; in posterior aspect, comb at inner emargination partly covered in middle; posterior face with long yellow setae.

Aedeagus smoothly curved; apical lobe slender; apex of apical lobe obtuse; without sensillae at inner edge of apical lobe.

\section{Osoriellus flaveolus n. sp.} (Figs 50A-C, 95C)

Type material: Holotype, male: Ecuador: Rio Napo, Limóncocha, $40 \mathrm{~km}$ E Puerto Francisco de Orellana/La Coca, 21.-27.11.1979, leg. J. Balogh (NHMH).

Diagnosis: The species resembles $O$. bicolor, O. levyi, and O. salvini. It can be differentiated from these three species by the iridescent shine of the head and the sparser and weaker punctation of the head and pronotum.

Description: Length: $3.7-3.8 \mathrm{~mm}$. Colouration: Light brown; head and posterior margin of elytra darker brown; elytra, legs and antennae yellow.

Head: $0.48 \mathrm{~mm}$ long, $0.74 \mathrm{~mm}$ wide; eyes slightly prominent; sides of fore-head deeply emarginate; side of clypeus parallel; front edge of clypeus even and without lateral teeth, but with slight emargination; setiferous punctation sparse and fine; irregularly dense; wide impunctate midline; on average, interstices between punctures as wide as diameter of punctures; surface with iridescent shine. Antennae slightly longer than head and half of pronotum combined; second antennomere oblong; conical third antennomere slightly shorter than second; follow- 
ing antennomeres slightly increasing in width; fourth and fifth antennomeres slightly longer than wide, sixth quadrate; seventh to tenth antennomeres wider than preceding antennomeres, but also quadrate.

Pronotum: $0.76 \mathrm{~mm}$ long, $0.80 \mathrm{~mm}$ wide; widest at anterior angles; slightly convergent to obtuse posterior angles in smooth curve; lateral margin fine; slightly thicker close to posterior angles than at anterior angles; in dorsal aspect, visible throughout its total length except close to anterior angles; setiferous punctation sparse, but slightly deeper than on head; with wide impunctate midline; on average, interstices between punctures as wide as or slightly wider than diameter of punctures; with dense micro-punctation and extremely weak remains of microsculpture; surface slightly shiny, but not polished.

Elytra: $0.89 \mathrm{~mm}$ long, $0.89 \mathrm{~mm}$ wide; with weak coriaceous ground-sculpture; setiferous punctation in irregular rows; distinctly visible; surface slightly shiny.

Abdomen with moderately dense setiferous punctation; without microsculpture; surface polished and shiny.

Protibia: $0.50 \mathrm{~mm}$ long, $0.13 \mathrm{~mm}$ wide; slender; with 9 spines at outer edge; apical spines inserted on short digits; WLR: 1.66; in posterior aspect, comb at inner emargination visible throughout its total length; setation of posterior face sparse.

Aedeagus with thick apical lobe ending in short acute apex; inner edge of apical lobe with 3 sensillae.

Etymology: The specific name derived from the same Latin word meaning yellow and refers to the light brown to dark yellow colouration and, in particular, to the yellow elytra.

\section{Osoriellus franckei (WENDELER, 1955) new combination} (Figs 72A-C, 98A)

Osorius franckei WeNDELER, 1955: 197

Type material examined: Brazil: Santa Catarina, Nova Teutonia $\left(52^{\circ} 23^{\prime} \mathrm{W}, 27^{\circ} 11^{\prime} \mathrm{S}\right)$, male, leg. F. Plaumann (holotype in ZMHB).

\section{Further material examined:}

Brazil: São Paulo, Teodoro Sampaio $\left(52^{\circ} 10.15^{\prime} \mathrm{W}\right.$, $22^{\circ} 31.56^{\prime}$ S), 2 females, August 1973, leg. F.H. Oliveira (AMNH, UIC); Santa Catharina, Corupa $\left(49^{\circ} 13^{\prime} \mathrm{W}\right.$, $26^{\circ} 26^{\prime}$ S), Hansa Humboldt, female, Sept. 1948, leg. A. Maller (AMNH).

Diagnosis: Among the species of similar size and without pronotal microsculpture, O. franckei is characterised by the specific punctation of the pronotum. Compared to O. parumpunctatus, the pronotal punctation is denser, compared to O. tuxtlae and O. minor, the pronotal punctation is sparser. The aedeagus is charaterised by its strongly curved long apical lobe with only few sensillae on its inner edge.
Description: Length: $4.4 \mathrm{~mm}$. Colouration: Black; elytra dark reddish-brown; legs and antennae reddish.

Head: $0.59 \mathrm{~mm}$ long, $0.90 \mathrm{~mm}$ wide; eyes not prominent; slightly longer than temples; sides of fore-head strongly narrowed in concave curve to anterior angles; front edge of clypeus even with short stout granules at angles; setiferous punctation on supraocular area coriaceous, on vertex coarse and dense, and on clypeus slightly sparser than on disc; wide midline impunctate; microsculpture weak, but dense; on supraocular area much denser and surface matter than on vertex; surface on vertex moderately shiny.

Antennae with oblong second antennomere; conical third antennomere as long as second; following three antennomeres approximately quadrate and as thick as preceding antennomeres; antennomeres 7 to 11 distinctly thicker than preceding antennomeres, but also approximately quadrate.

Pronotum: $0.88 \mathrm{~mm}$ long, $0.94 \mathrm{~mm}$ wide; widest at anterior angles; distinctly convergent to posterior angles in smooth curve; posterior angles smoothly rounded; lateral margin fine; in dorsal aspect, nearly invisible close to anterior angles; setiferous punctures much larger than on head; partly elongate and in irregular rows; row adjacent to impunctate midline consisting of 10 large punctures; on average, interstices between punctures of adjacent rows half as wide as diameter of punctures; distance between punctures within rows only one-fourth as wide as diameter of punctures; with weak netlike microsculpture and with sparse micro-punctation; surface shiny.

Elytra: $0.92 \mathrm{~mm}$ long, $0.95 \mathrm{~mm}$ wide; with weak coriaceous ground-sculpture; setiferous punctation in irregular rows; surface shiny.

Abdomen with dense setiferous punctation and impunctate midline; yellow setae pointing to midline; with weak netlike microsculpture; surface less shiny than on elytra and pronotum.

Protibia: $0.50 \mathrm{~mm}$ long, $0.15 \mathrm{~mm}$ wide; with 7 spines at outer edge; WLR: 1.6; in posterior aspect, comb of inner emargination totally visible; posterior face densely covered by yellow setae.

Aedeagus elongately curved; angulate in nearly rectangular angle.

\section{Osoriellus frater (LYNCH, 1884) new combination (Figs 73A, 97F)}

Osorius frater LYNCH, 1884: 346

Material examined: Paraguay: Villarica, female, 1939, determined as O. frater (AMNH).

Diagnosis: Compared to the other species of similar size, $O$. frater can be identified by the nearly parallel sides of the pronotum. The type specimen was not found in the Museo Argentino de Ciencias Naturales 'Bernadino Rivadavia', Buenos Aires. The specimen determined as 
O. frater in AMNH highly coincides with the description made by Lynch Arribálzaga (1884), in particular, concerning the parallel sides of the pronotum. Lynch described a size variance of $5-6 \mathrm{~mm}$. The specimen in AMNH is slightly larger. Unfortunately only a female specimen could be studied.

Description: Length: $6.4 \mathrm{~mm}$. Colouration: Brown; pronotum slightly lighter than head; elytra and posterior edge of abdominal segments reddish; legs red; antennae dark red.

Head: $0.8 \mathrm{~mm}$ wide, $1.2 \mathrm{~mm}$ wide; eyes not prominent; sides of fore-head distinctly convergent to front angles of clypeus; angles of clypeus produced to short granule; front edge of clypeus even; supra-ocular setiferous punctation granulate; punctures coriaceous; punctures on vertex large and dense with impunctate midline; setiferous punctures on clypeus partly granulate; area at base of antennae impunctate; on vertex, interstices between punctures half as wide as diameter of punctures; netlike microsculpture distinct; surface slightly shiny; central area close to neck and area at base of antennae without microsculpture; surface polished.

Antennae only slightly longer than head with second antennomere globular and third conical; third antennomere not longer than second; fourth antennomere slightly smaller than third; following antennomeres increasing in width; antennomeres 4 to 6 approximately quadrate; penultimate antennomeres slightly wider than long.

Pronotum: $1.2 \mathrm{~mm}$ long, $1.3 \mathrm{~mm}$ wide; widest at anterior angles; slightly and evenly narrowed to posterior smoothly rounded angles; sides with narrow margin; punctures large in irregular rows and with wide impunctate midline; row of punctures adjacent to midline coarse, nearly coriaceous; laterally punctation sparser; very sparse micro-punctation present; without microsculpture; surface polished.

Elytra: $1.25 \mathrm{~mm}$ long, $1.25 \mathrm{~mm}$ wide; with coriaceous ground-sculpture; setiferous punctation nearly invisible in coarse ground-sculpture; punctures deep and irregularly dense; surface less shiny than on pronotum.

Abdomen densely and deeply punctate; punctures setiferous; midline impunctate; weak netlike microsculpture present; surface slightly shiny.

Protibia: $0.72 \mathrm{~mm}$ long, $0.30 \mathrm{~mm}$ wide, 8 spines at outer edge; apical spines on short broad digits; WLR: 2.6; in posterior aspect, comb of inner emargination totally visible; posterior face densely covered by yellow setae. Aedeagus unknown.

Osoriellus fumarius $\mathrm{n}$. sp.

(Figs 92A-C, 100F)

Type material: Holotype, male: Peru: Huanuco Prov., Panguana, Cocha, collected between June - October 1976, leg. W. Hanagarth (UIC).
Diagnosis: The species is very similar to O. caliginosus concerning the sligthly sinuate sides of the pronotum. The further differentiating characters are described under O. caliginosus.

Description: Length: $6.4 \mathrm{~mm}$. Colouration: Black; legs and antennae dark brown; elytra and abdomen lighter brown.

Head: $0.81 \mathrm{~mm}$ long, $1.33 \mathrm{~mm}$ wide; eyes slightly prominent; approximately twice as long as temples; sides of fore-head narrowed to slightly produced anterior angles in smoothly concave curve; anterior edge of clypeus slightly emarginate; setiferous punctation moderately deep and irregularly dense; on clypeus much sparser than close to neck; wide midline, area at base of antennae and transverse oval area close to neck impunctate; on clypeus, interstices between punctures at least as wide as diameter of punctures; on vertex, interstices between punctures approximately half as wide as diameter of punctures; on supracocular area punctation still denser; partly coriacous; setae long and yellow; isodiametric microsculpture dense, but weak; surface slightly shiny.

Antennae slightly longer than head; second antennomere oval; slightly longer than conical third antennomere; antennomeres four to six as wide as preceding antennomeres, but quadrate; following antennomeres slightly wider than preceding antennomeres and also quadrate; last antennomere elongately oval and less wide than tenth antennomere.

Pronotum: $1.19 \mathrm{~mm}$ long, $1.42 \mathrm{~mm}$ wide; widest close to rectangular anterior angles; in anterior half slightly narrowed; in posterior half strongly narrowed in concave curve to rectangular posterior angles; lateral margin distinct; in dorsal aspect, covered close to anterior angles; widened close to posterior angles; setiferous punctation deep and moderately dense; on average, interstices between punctures approximately twice as wide as diameter of punctures; wide midline impunctate; isodiameteric microsculpture as dense as but deeper than on head; surface matt.

Elytra: $1.50 \mathrm{~mm}$ long, $1.49 \mathrm{~mm}$ wide; shoulders shortly rounded; sides slightly widened to posterior third; setiferous punctation as deep as but denser than on pronotum; coriacous ground-sculpture weak, but isodiametric microsculpture as deep as and as dense as on pronotum; surface matt.

Abdomen with dense setiferous punctation; narrow midline impunctate; netlike microsculpture weak; surface shiny.

Protibia: $0.63 \mathrm{~mm}$ long, $0.23 \mathrm{~mm}$ wide; nearly semicircular; outer edge with 9 spines; apical spines inserting on very short digits; WLR: 1.8; in posterior aspect, comb at inner emargination visible throughout its total length; posterior face with moderately dense setation.

Aedeagus angulate in obtuse angle; basal lobe thick; apical lobe more slender; apical lobe evenly narrowed from base to obtuse apex; inner edge of apical lobe with numerous sensillae. 
Etymology: The specific name fumarius derives from the same Latin word and means dark brown. It refers to the dark brown colouration of the species.

\section{Osoriellus grossopunctatus $\mathrm{n} . \mathrm{sp}$ (Figs 56A-C, 95D)}

Type material: Holotype, male: Paraguay: Hungarian Soil-Zool. Exp. Puerto Presidente Stroessner, 2.1.1966, leg. I. Loksa (NHMH).

Paratypes: 2 males, 1 female with the same data as the holotype (NHMH, UIC).

Diagnosis: The species is characterised by the large prominent eyes and in this respect it resembles $O$. surinamensis and $O$. asperatus. The last species have either a denser and finer or a coriaceous pronotal punctation. Concerning the large eyes, it also resembles O. ocularis and O. oculatus of the O.-oculatus-group, but in O. grossopunctatus the anterior edge of the clypeus is even and not denticulate as in those two species. Compared to O. micros with smaller eyes, O. grossopunctatus has a more triangular pronotum and a larger and coarser pronotal punctation.

Description: Length: $3.5 \mathrm{~mm}$. Colouration: Brown; elytra light reddish; legs and antennae yellow.

Head: $0.50 \mathrm{~mm}$ long, $0.64 \mathrm{~mm}$ wide; eyes distinctly prominent; slightly longer than temples; sides of forehead slightly emarginate to anterior angles of clypeus; anterior edge of clypeus even; setiferous punctation fine and dense; narrow midline impunctate; distance between punctures as wide as to half as wide as diameter of punctures; on supraocular area punctation denser than on front head; netlike microsculpture deep and dense; surface matt.

Antennae only slightly longer than head; second antennomere globular; thicker than following 3 antennomeres; conical third antennomere shorter than second; fourth to sixth antennomere only slightly wider than third, but wider than long; following 5 antennomeres much thicker than preceding antennomeres and distinctly wider than long; penultimate antennomere 1.5 times wider than long.

Pronotum: $0.60 \mathrm{~mm}$ long, $0.67 \mathrm{~mm}$ wide; widest at obtuse anterior angles and evenly narrowed to posterior angles; slightly in front of widely rounded posterior angles stronger narrowed; lateral margin moderately thick; in dorsal aspect, near anterior angles not visible; setiferous punctation deep and dense; interstices between punctures not wider than one-fourth of diameter of punctures; row of punctures adjacent to impunctate midline still denser; partly forming short furrow; between large punctures with dense micro-punctation; microsculpture irregularly dense and deep; near anterior margin and along midline with deeper and denser microsculpture; surface matt; on disc large areas without microsculpture; surface polished and shiny.
Elytra: $0.81 \mathrm{~mm}$ long, $0.70 \mathrm{~mm}$ wide; ground-sculpture deep and coriaceous; punctation in irregular rows; hardly visible in ground-sculpture.

Abdomen with dense and large setiferous punctation; distance between punctures less wide than half of diameter of punctures; irregular microsculpture weak; surface slightly shiny.

Protibia: $0.41 \mathrm{~mm}$ long, $0.12 \mathrm{~mm}$ wide; semi-circular; with 8 spines at outer edge; WLR: 3.0; in posterior aspect, comb at inner emargination totally visible; posterior face with moderately dense setation.

Aedeagus with triangular apical lobe ending in obtuse apex; at inner edge of apical lobe 2 sensillae with short setae.

Etymology: The specific name is a combination of the epithet grosso meaning thick and punctatus meaning punctate and refers to the thick punctation of the pronotum.

\section{Osoriellus haitiellus (DARLINGTON, 1937) new combination \\ (Figs 86A-C, 101B)}

Osorius haitiellus DARLINGTon, 1937: 6

Osorius haitiellus BLACKWELDER, 1943: 193

Type material examined: Haiti: Massif de la Hotte, 20004000 feet, female (paratype in NMNH).

Further Material examined: Dominican Republic: Prov. La Vega, 7.2 mi SE Constanza Rd. to San José de Ocoa, $5000 \mathrm{ft}$ elevation, litter nr. stream, male, July, 29, 1991, leg. L. Herman, \# 2578-81 (AMNH).

Diagnosis: The species resembles O. rugipennis and $O$. franckei in size. Compared to O. rugipennis, the pronotal punctation is sparser. Compared to O. franckei, the pronotal microsculpture is more distinct and the surface is less shiny.

Description: Length: 4.7. Colouration: Black; legs and antennae light brown.

Head: $0.61 \mathrm{~mm}$ long, $0.94 \mathrm{~mm}$ wide; eyes not prominent; as long as temples; anterior angles of clypeus produced to short acute teeth; anterior edge between teeth even; setiferous punctation distinct and moderately dense; on average, interstices between punctures as wide as diameter of punctures; at bae of antennae, small area impunctate; on supraoculare area with granulate punctures; netlike microsculpture distinct; surface slightly shiny.

Antennae as long as head and half of pronotum combined; second antennomere oblong and slightly longer than conical third; following antennomeres increasing in width; antennomeres four to ten approximately quadrate and with long yellow setae. 
Pronotum: $0.96 \mathrm{~mm}$ long, $1.04 \mathrm{~mm}$ wide; widest at anterior angles; anterior angles rectangular or slightly produced to extremely short acute teeth; sides in anterior half nearly parallel; in posterior half distinctly narrowed to obtuse posterior angles; lateral margin fine; in dorsal aspect, not visible close to anterior angles; setiferous punctation large; in irregular rows; row adjacent to impunctate midline with approximately 10 punctures; on disc, interstices between punctures as wide as or slightly wider than diameter of punctures; between setiferous punctation with dense micro-punctation; netlike microsculpture distinct; surface slightly shiny.

Elytra: $1.13 \mathrm{~mm}$ long, $1.08 \mathrm{~mm}$ wide; with weak coriaceous ground-sculpture; setiferous punctures in irregular rows.

Abdomen densely punctate with setiferous punctures; netlike microsculpture weaker than on fore-body and surface shinier.

Protibia: $0.51 \mathrm{~mm}$ long, $0.19 \mathrm{~mm}$ wide; with 7 spines at outer edge; apical spines on short digits; WLR: 1.66; in posterior aspect, comb of inner edge visible throughout its total length; posterior face densely covered by yellow setae.

Aedeagus with long and slender apical lobe; apical lobe smoothly curved to acute apex; inner edge of apical lobe with row of several sensillae.

\section{Osoriellus huggerti n. sp.}

(Figs 49A-C, 95B)

Type material: Holotype, male: Ecuador: Napo, Baeza, 12.-22.11.1983, leg. L. Huggert (NHMS).

Paratypes: female with same locality as holotype, but 13.11.1983, leg. L. Huggert (NHMS).

Diagnosis: Concerning the iridescent shine of the head and pronotum, the species resembles O.flaveolus. In contrast to $O$. flaveolus, the punctation of the pronotum is distinctly denser. Whereas the pronotal punctation of O. flaveolus is sparse with the interstices between the punctures much wider than the diameter of punctures, the interstices between the pronotal punctures in $O$. huggerti are less than half of the diameter of the punctures.

Description: Length: $3.5 \mathrm{~mm}$ long. Colouration: Dark brown; legs and antennae reddish.

Head: $0.53 \mathrm{~mm}$ long, $0.73 \mathrm{~mm}$ wide; eyes slightly shorter than temples; sides in front of eyes shortly convergent to front angles; front angles of clypeus produced to short triangular teeth; front edge between teeth slightly emarginate; setiferous punctation moderately dense and deep; on average, interstices between punctures slightly shorter than diameter of punctures; with wide impunctate midline on vertex and small impunctate area at base of antennae; microsculpture fine; mostly isodiameteric; surface with iridescent shine.
Antennae nearly as long as head and half of pronotum combined; second antennomere thicker and slightly longer than third; following antennomeres increasing in width and approximately quadrate; only eighth and nineth antennomeres wider than long.

Pronotum: $0.74 \mathrm{~mm}$ long, $0.77 \mathrm{~mm}$ wide; widest at anterior angles; evenly convergent to obtuse posterior angles; lateral margin fine; at anterior angles finer than at posterior angles; setiferous punctures large; in irregular rowes; interstices between punctures shorter than diameter of punctures; in row adjacent to impunctate midline less than half of diameter of punctures; irregular microsculpture similar as on head, but still weaker; surface with iridescent shine.

Elytra: $0.75 \mathrm{~mm}$ long, $0.76 \mathrm{~mm}$ wide; with coarse coriaceous ground-sculpture; setiferous punctation in irregular rows.

Abdomen with setiferous punctation on all tergites; irregular impunctate midline only on posterior tergites VI to VIII; without or only weak traces of microsculpture; surface shiny.

Protibia: $0.43 \mathrm{~mm}$ long, $0.13 \mathrm{~mm}$ wide; 8 spines on outer edge; apical spines on short digits; WLR: 1.36 ; in posterior aspect, comb of inner emargination visible throughout its total length; posterior face with moderately dense long yellow setation.

Aedaegus elongate; apical lobe straight at base, then suddenly angulate in nearly rectangular angle and narrowed to acute apex; without sensillae at inner edge of apical lobe.

Etymology: The specific name derived from the name of its collector, L. Huggert.

\section{Osoriellus humicola n. sp.} (Figs 63A-C, 97E)

Type material: Holotype, male: Honduras: Octotepeque, $12.7 \mathrm{~km} \mathrm{E} \mathrm{\&} 2.4 \mathrm{~km} \mathrm{~S}$ Ocotepeque, Mp O. Sinuapa $\left(89^{\circ} 04^{\prime} \mathrm{W}, 14^{\circ} 27^{\prime} \mathrm{N}\right)$, forest litter berlese, $1450 \mathrm{~m}$ elevation, 15.6.1994, leg. R. Anderson, \#118A (KNHM).

Paratypes: Honduras: 1 female and 1 male with same data as for holotype (KNHM, UIC); Guatemala: Tactic, Verapaz, 6. km W, sifting litter, under bushes of road side, trop. mont. forest, 1 female, 22.11.1991, R. Baranowski.

Diagnosis: The species extremely resembles O.eggersi in size and both shape and punctation of the pronotum. It can be separated by the less dense punctation of the fore-head and mainly by the shape of the aedeagus. In O. eggersi, the punctation of the fore-head is as dense as on the vertex. In O. humicola, the punctation of the forehead is distinctly sparser than on the vertex. The apical lobe of the aedeagus of O. humicola is evenly curved on outer edge and the apex is obtuse, whereas in O. eggersi the outer edge of the apical lobe is sinuate and the apex is 
acute. The distribution of sensillae is similar, but the setae of the sensillae of $O$. eggersi are very long.

Description: Length: 3.8. Colouration: Brown; pronotum and elytra lighter brown; legs and antennae reddish.

Head: $0.55 \mathrm{~mm}$ long, $0.80 \mathrm{~mm}$ wide; eyes not prominent; temples 1.5 times as long as eyes; sides of fore-head evenly narrowed in slightly concave curve to anterior angles; setiferous punctation irregularly dense and deep; on vertex denser than on fore-head; wide midline and area at base of antennae impunctate; on vertex, interstices between punctures half as wide as diameter of punctures; on fore-head, interstices at least as wide as diameter of punctures; without microsculpture; surface polished and shiny.

Antennae slightly longer than head; second antennomere longer than wide and nearly 1.5 times as long as conical third antennomere; antennomeres 4 to 6 as wide as preceding antennomeres, but quadrate; antennomeres 7 to 10 distinctly wider than preceding antennomeres and nearly twice as wide as long.

Pronotum: $0.74 \mathrm{~mm}$ long, $0.79 \mathrm{~mm}$ wide; widest at anterior angles; anterior angles obtuse in short curve; in anterior half, sides slightly narrowed posteriad; in posterior half, sides distinctly convergent to widely rounded posterior angles; lateral margin very fine; in dorsal aspect, invisible in anterior half; setiferous punctation dense and coarse; impunctate midline narrower than on head; punctures partly coriaceous; interstices between punctures less than half as wide as diameter of punctures; with sparse micro-punctation; without microsculpture; surface polished and shiny.

Elytra: $0.80 \mathrm{~mm}$ long, $0.80 \mathrm{~mm}$ wide; setiferous punctation dense and coarse; in irregular rows; ground-sculpture weakly coriaceous.

Abdomen with dense setiferous punctation except on narrow impunctate midline; without microsculpture; nearly polished and shiny.

Protibia: $0.42 \mathrm{~mm}$ long, $0.15 \mathrm{~mm}$ wide; with 10 spines at outer edge; WLR: 2.60; in posterior aspect, comb at inner edge visible throughout its total length; posterior face densely covered by yellow setae.

Aedeagus with evenly curved apical lobe ending in obtuse apex; inner edge of apical lobe with two groups of sensillae; basal group with six sensillae; apical group with four sensillae.

Etymology: The specific name derived from the Latin word humus meaning soil and refers to the litter dwelling behaviour of the species.

\section{Osoriellus indescriptus n. sp.}

(Figs 44A-C, 94B)

Type material: Holotype, male: USA, Bahamas: South Bimini Island, 1.4.1952, leg. E. Mayr (AMNH).
Paratypes: USA, Bahamas: 30 specimens with same data as holotype; 99 specimens, 1.5.1951, leg. C. Crazier; 17 specimens 1.6.1951, leg. C. Crazier; 5 specimens, 1.7.1951, leg. P. Vaurio; 11 specimens, 1.8.1951, leg. P. Vaurio (ANHM, UIC); Andros Island, Middenhair Coppice, $2.1 \mathrm{mi} \mathrm{S}, 0.7 \mathrm{mi}$ E Staniard Creek, low interior coppice litter, 1 specimen, 6.05.1994, R. Anderson (AMNH); Church's Blue Hole, $1.7 \mathrm{mi}$ E Love Hill, high interior coppice litter, 4 specimens, 26.04.1994, leg. R. Anderson (KNHM); London Ridge, $2.7 \mathrm{mi} \mathrm{N}, 0.8 \mathrm{mi}$ E Forfar F. Stn., high interior coppice litter, 1 specimen, 06.05.1994, leg. R. Anderson (KNHM).

Diagnosis: The species is closely related to O. exiguus. Both species cannot be shurely identified without dissection of the aedeagus. On average, $O$. indescriptus is more slender and slightly darker than O. exiguus and the punctation of the pronotum is slightly deeper and denser. However, the species can be easily separated by the shape of the aedeagus. The apical lobe of O. exiguus is slender and smoothly curved, whereas it is thick and triangular in O. indescriptus.

Description: Length: $2.5 \mathrm{~mm}$ long. Colouration: Light brown; head darker brown; elytra, legs and antennae yellow; posterior margin of elytra dark.

Head: $0.42 \mathrm{~mm}$ long, $0.50 \mathrm{~mm}$ wide; eyes not prominent; slightly shorter than temples; sides of fore-head deeply emarginate; sides of clypeus nearly parallel; apical edge of clypeus even; without granules at angles; setiferous punctation deep and dense; interstices between punctures less than half as wide as diameter of punctures; small area at base of antennae and midline on vertex impunctate; without microsculpture; surface polished and shiny.

Antennae as long as head; second antennomere globular and thick; thicker than three following antennomeres; triangular third antennomere shorter and smaller than second; fourth antennomere as wide as third, but shorter and wider than long; following antennomeres increasing in width; fifth to eighth antennomeres wider than long; nineth and tenth antennomeres nearly quadrate.

Pronotum: $0.57 \mathrm{~mm}$ long, $0.51 \mathrm{~mm}$ wide; widest at anterior angles; evenly convergent to rounded posterior angles; setiferous punctation deep and dense; still denser and deeper than on head; interstices between punctures less than half as wide as diameter of punctures; narrow midline impunctate; without microsculpture; surface polished and shiny.

Elytra: $0.56 \mathrm{~mm}$ long, $0.50 \mathrm{~mm}$ wide; with weak coriaceous ground-sculpture; setiferous punctation fine and less deep than on pronotum and head.

Abdomen with large setiferous punctation; nearly as deep and dense as on pronotum; narrow midline on posterior tergites impunctate.

Protibia: $0.27 \mathrm{~mm}$ long, $0.08 \mathrm{~mm}$ wide; with 8 spines at outer edge; WLR: 3.0; comb at inner edge visible throughout its total length; posterior face with few yellow setae. 
Aedeagus with short, thick and triangular apical lobe; nearly as thick as basal lobe; inner edge of apical lobe without sensillae.

Etymology: The specific name is a combination of the epithet in and the Latin word describere meaning not described. The name refers to the confusion between this species and $O$. exiguus during my studies.

\section{Osoriellus latipes (GRAVENHORST, 1806) new combination \\ (Figs 74A-C, 99A)}

Oxytelus latipes GravenHORST, 1806: 198

Osorius mundus SHARP, 1887: 432 new synonymy

Type material examined: America septentrionalis: female without further data (lectotype in ZMHB); Mexico: Mexico City, 2 males, leg. Flohr (syntypes of O. munus in BMNH).

Diagnosis: The species resembles O.brevicornis, O. rugipennis and O.neotropicus due to the structure and punctation of the pronotum. It can be easily distinguished from those species by the long antennae with elongate second and third antennomere. In contrast to O. latipes, O. rugipennis and O. brevicornis, O. neotropicus has a digitate protibia. It can be also confused with O. mexicanus and O.cordovensis, but O. latipes has an extremely fine netlike microsculpture that is absent in the other two species. The two syntypes of O. latipes are damaged. I selected the smaller one as lectotype. It seems that both type specimens are not conspecific.

Description: Length: $6.6 \mathrm{~mm}$. Colouration: Dark red; pronotum and elytra lighter red; legs and antennae yellow. Head: $0.90 \mathrm{~mm}$ long, $1.35 \mathrm{~mm}$ wide; eyes slightly prominent; as long as temples; vertex densely and deeply punctate; on average, interstices between punctures half as wide as diameter of punctures; wide midline with sparser punctation or partly impunctate; area at base of antennae impunctate and without microsculpture; surface polished; surface of vertex with distinct netlike microsculpture; slightly shiny; supraocular area densely covered by striae and granulate punctures.

Antennae with second antennomere oblong; distinctly longer than wide and as long as conical third; following three antennomeres quadrate and as wide as preceding two antennomeres; antennomeres 7 to 10 distinctly wider than preceding antennomeres, but still more or less quadrate.

Pronotum: $1.30 \mathrm{~mm}$ long, $1.40 \mathrm{~mm}$ wide; widest at anterior angles; approximately parallel in anterior half; distinctly convergent in posterior half; at posterior edge approximately half as wide as at anterior edge; lateral and posterior margin fine; with irregular and dense setiferous punctation; longitudinal row of 8 to 10 punctures on each side of wide impunctate midline; on average, interstices between lateral punctures as wide as diameter of punctures or slightly shorter; with few areas more sparsely punctate; anterior edge without margin, but with transverse row of dense punctures; surface with extremely weak netlike microsculpture; nearly polished.

Elytra: $1.50 \mathrm{~mm}$ long, $1.40 \mathrm{~mm}$ wide; with dense and distinct coriaceous ground-sculpture; irregular rows of punctures hardly visible between ground-sculpture.

Abdomen with dense setiferous punctation, setae much longer than setae on pronotum; surface with distinct netlike microsculpture.

Protibia: $0.56 \mathrm{~mm}$ long, $0.20 \mathrm{~mm}$ wide; 10 spines at outer edge; apical spines not inserted on digits; WLR: 4.0; in posterior aspect, comb of inner emargination partly covered in middle; posterior face densely covered by moderately long setae.

Aedeagus with long apical lobe and acute apex; without sensillae at inner edge.

\section{Osoriellus latitibialis n. sp.}

(Figs 52A-C, 95A)

Type material: Holotype, male: Napo, $81 \mathrm{~km}$ NE of Baeza, $3 \mathrm{~km} \mathrm{SW}$ Reventador $\left(77^{\circ} 41^{\prime} \mathrm{W}, 0^{\circ} 06^{\prime} \mathrm{S}\right), 1750 \mathrm{~m}$ elevation, sampled from litter, 28./29.10.1988, leg. L. Herman (AMNH).

Paratype: Ecuador: $69 \mathrm{~km} \mathrm{NE}$ of Baeza, $15 \mathrm{~km} \mathrm{SW}$ of Reventador $\left(77^{\circ} 44^{\prime} \mathrm{W}, 0^{\circ} 09^{\prime} \mathrm{S}\right), 1500 \mathrm{~m}$ elevation, sampled from foliage, female, 28.-30.10.1988, leg. L. Herman (UIC).

Diagnosis: O. latitibialis is characterised by the typical shape of the protibia. It slightly resembles $O$. eggersi and O. carinicollis in size and dense pronotal punctation. But the shape of the pronotum is more parallel than in these two species with a trapezoidal pronotal shape.

Description: Length: 3.6 - $3.7 \mathrm{~mm}$. Colouration: Black; legs and antennae reddish; anterior margin of clypeus yellow.

Head: $0.47 \mathrm{~mm}$ long, $0.65 \mathrm{~mm}$ wide; eyes as long as temples; not prominent; sides of fore-head emarginate; anterior margin even; on supraocular area, setiferous punctation dense and distinct; fore-head and clypeus very sparsely punctate; on clypeus interstices between punctures as wide as diameter of punctures; on vertex much denser; interstices between punctures less than one-fourth of diameter of punctures; setae yellow and extremely long; on vertex with narrow impunctate midline; on densely punctate supraocular area with remains of microsculpture; on central vertex and forehead without microsculpture; surface polished and shiny.

Antennae with oval second antennomere and conical third antennomere; third antennomere slightly shorter than second; antennomeres 4 to 6 quadrate and not wider 
than preceding antennomeres; following antennomeres slightly thicker than preceding antennomeres; approximately quadrate.

Pronotum: $0.64 \mathrm{~mm}$ long, $0.71 \mathrm{~mm}$ wide; widest at anterior angles; sides in anterior two-third nearly parallel; in posterior third, smoothly narrowed in convex curve to obtuse posterior angles; lateral margin narrow; in dorsal aspect, only visible in posterior third; setiferous punctures dense and deep; nearly coriaceous; interstices between punctures less than one-fourth of diameter of punctures; narrow midline impunctate; yellow setae extremely long; without microsculpture; based on dense punctation surface matt.

Elytra: $0.75 \mathrm{~mm}$ long, $0.70 \mathrm{~mm}$ wide; with setiferous punctation; punctation nearly coriaceous; yellow setae extremely long; surface without microsculpture; based on dense punctation matt.

Abdomen with dense setiferous punctation, but slightly less dense than on elytra.

Protibia: $0.50 \mathrm{~mm}$ long, $0.17 \mathrm{~mm}$ wide; asymmetric; widest in apical third; on outer edge with 8 slender and short spines; WLR: 2.50; in posterior aspect, comb of inner emargination partly covered in apical third; posterior face covered by very long yellow setae; setae longer than half of protibial width.

Aedeagus with long, smoothly rounded apical lobe; apex acute.

Etymology: The specific name is a combination of the epithet latus meaning broad and tibia. It refers to the specific shape of the front leg.

\section{Osoriellus levyi in. sp.}

(Figs 58A-C, 96D)

Type material: Holotype, male: Ecuador: Napo Prov., Jatun Sacha Biol. Station, $21 \mathrm{~km}$ E Puerto Napo (77 $\left.36.48^{\prime} \mathrm{W}, 01^{\circ} 04.06^{\prime} \mathrm{S}\right), 400 \mathrm{~m}$ elevation, collected by flight intercept trap in virgin rain forest, 15.7.1994, leg. Levy \& Genier (KNHM).

Diagnosis: The species resembles O. bicolor in size, colouration and micro-punctation of the fore-body. The pronotal punctation in O. bicolor is much deeper and denser than in O. levyi. In O. bicolor, the interstices between the punctures are approximately half as wide as diameter of punctures, whereas they are at least as wide as diameter of punctures in O. levyi. The strong curved apical lobe of the aedeagus and the acute apex is characteristic for O. levyi, too.

Description: Length: $3.3 \mathrm{~mm}$. Colouration: Dark brown; posterior margin of pronotum and clypeus yellow; legs and antennae yellow.

Head: $0.46 \mathrm{~mm}$ long, $0.63 \mathrm{~mm}$ wide; eyes slightly prominent and as long as temples; sides of fore-head deeply sinuate and convergent to anterior margin of clypeus; sides of clypeus parallel; anterior margin of clypeus even, without teeth at outer angles; setiferous punctation moderately dense; punctures large, but not deep; wide midline and area at base of antennae impunctate; on average, interstices between punctures as wide as diameter of punctures; without microsculpture except small areas with remains of extremely weak microsculpture; between coarse punctures with micro-punctation; surface shiny and mostly polished.

Antennae as long as head and half of pronotum combined; second antennomere oval and slightly longer than wide; conical third antennomere smaller than second and only as long as wide; following three antennomeres approximately as wide as third, but shorter; fourth antennomere quadrate, sixth nearly twice as wide as long; antennomeres 7 to 10 much thicker than preceding antennomeres and distinctly wider than long.

Pronotum: $0.65 \mathrm{~mm}$ long, $0.64 \mathrm{~mm}$ wide; widest at obtuse anterior angles; evenly and slightly narrowed to posterior smoothly rounded angles; lateral margin extremely fine; in dorsal aspect, visible throughout its total length; setiferous punctation moderately dense, but punctures larger and deeper than on head; wide midline impunctate; on average, interstices between punctures as wide as diameter of punctures; in row adjacent to midline, interstices between punctures shorter; without microsculpture; surface polished and shiny.

Elytra: $0.80 \mathrm{~mm}$ long, $0.72 \mathrm{~mm}$ wide; with deep and dense ground-sculpture; setiferous punctation in irregular rows; punctures hardly visible in ground-sculpture; on disc 4 rows of punctures.

Abdomen with dense setiferous punctation and narrow impunctate midline; with remains of microsculpture; surface moderately shiny.

Protibia: $0.35 \mathrm{~mm}$ long, $0.15 \mathrm{~mm}$ wide; nearly semicircular; 9 long spines at outer edge; WLR: 3.0; in posterior aspect, comb of inner emargination partly covered; setation on posterior face dense.

Aedeagus with long prominence in middle and strongly curved apical lobe ending in acute apex.

Etymology: The specific name derived from the collector of the species, Mr. Levy.

Osoriellus lewisi (BLACKWELDER, 1943) new combination (Figs 48A-C, 102B)

Osorius lewisi Blackwelder, 1943: 197

Type material examined: Great Britain, Grand Cayman Island: West End of Georgetown, 25.4.1938, leg. C.B. Lewis \& G.H. Thompson (holotype destroyed in BMNH).

Further material examined: Great Britain, Grand Cayman Island: S.W. Point, ex suction trap, 6 females, 11.-12.11.1970, leg. J. Davies (BMNH); Cuba: Prov. Artemisia, Cayamas $\left(80^{\circ} 34^{\prime} \mathrm{W}, 22^{\circ} 16^{\prime} \mathrm{N}\right)$, leg. E.A. Schwarz 
(AMNH); Prov. Guantanamo, El Yunque $\left(74^{\circ} 34^{\prime} \mathrm{W}\right.$, $\left.20^{\circ} 21^{\prime} \mathrm{N}\right)$, ca. $2 \mathrm{~km} \mathrm{~W}$ of campismo popular, 1 female, 1 male, 11.06.2012, leg. Cala-Riquelme, Deler-Hernández \& M. Fikáček (NHMP, UIC); Santa Maria, PN Humboldt, ca. 1.5-3 km SW of Santa Maria $\left(74^{\circ} 42.04^{\prime} \mathrm{W}, 20^{\circ} 30.06^{\prime} \mathrm{N}\right)$, "Nuevo Mundo", sifting slightly wet old accumulation of flood debris on side of road, riverine evergreen rainforest, near St. Maria River, female, 17.06.2012, leg. Deler-Hernández \& M. Fikáček (NHMP); Prov. Granma, La Platica $\left(76^{\circ} 53^{\prime} \mathrm{W}, 20^{\circ} 00^{\prime} \mathrm{N}\right)$, P.N. Turquino, La Mariposa, ca. $1 \mathrm{~km}$ SE La Platica (by air), sifting in old secondary evergreen forest with thick layer of leaf litter, male, 24.06.2012, leg. Deler-Hernández \& M. Fikáček (NHMP).

Diagnosis: In contrast to Blackwelder's (1943) statement, the species is more similar to O. micros and O. brevicornis than to O. eggersi due to the distinct microsculpture of the pronotum. In contrast to O. micros, the sixth antennomere is wider, similar as in O. brevicornis. Compared to O. brevicornis, the pronotum of O. lewisi is more distinctly convergent from anterior to posterior angles and the head and the pronotum are darker. The holotype is incomplete, without head and pronotum. The description based on the further material.

Description: Length: $3.9 \mathrm{~mm}$. Colouration: Dark brown; legs and antennae light brown.

Head: $0.59 \mathrm{~mm}$ long, $0.78 \mathrm{~mm}$ wide; eyes not prominent, longer than temples; sides of fore-head deeply emarginate; anterior edge of clypeus even; setiferous punctation dense and moderately deep; on vertex, interstices between punctures half as wide as diameter of punctures; on clypeus, interstices wider; isodiametric microsculpture deep and dense; surface matt.

Antennae as long as head and half of pronotum combined; second antennomere oblong; as thick and long as conical third; fourth and fifth antennomeres as wide as third, but shorter; approximately quadrate; following antennomeres increasing in width; tenth antennomere slightly wider than long.

Pronotum: $0.78 \mathrm{~mm}$ long, $0.82 \mathrm{~mm}$ wide; widest at obtuse anterior angles; sides in anterior half less narrowed than in posterior half; posterior angles widely rounded; setiferous punctation deep and larger than on head; moderately wide midline impunctate; lateral margin fine; at anterior angles nearly invisible in dorsal aspect; isodiametric microsculpture distinct; surface matt.

Elytra: $0.95 \mathrm{~mm}$ long, $0.84 \mathrm{~mm}$ wide; coriaceous groundsculpture deep; setiferous punctation in irregular rows; only slightly visible in deep ground-sculpture; surface matt.

Abdomen with dense and deep setiferous punctation; on tergites, narrow midline impunctate; microsculpture irregular; surface more shiny than on pronotum and head.

Protibia: $0.84 \mathrm{~mm}$ long, $0.27 \mathrm{~mm}$ wide; with 9 spines at outer edge; WLR: 2.0; in posterior aspect, inner comb of inner emargination covered in middle; posterior face densely covered by long yellow setae.

Aedeagus slender with slightly curved, nearly straight apical lobe; apex of apical lobe obtusely rounded; without sensillae at inner edge of apical lobe.

\section{Osoriellus loksai n. sp.}

(Figs 59A-C, 96E)

Type material: Holotype, male: Paraguay: Puerto Presidente Stroessner, Soil-Zool. Exp., 26.12.1965, leg. I. Loksa (NHMH).

Paratypes: Paraguay: 1 female with same data as holotype; Puerto Presidente Stroessner, Acaray water fall, Soil-Zool. Exp., female, 2.1.1966, leg. I. Loksa; Puerto Presidente Stroessner, Soil-Zool. Exp., female, 26.-29.12.1965, leg. J. Balogh, female, 5.1.1966, leg. J. Balogh \& L.S. Mahunka; Brazil: Paraná, Hungarian Soil-Zool.Exp., female, Foz do Iguazu, Iguazu Waterfalls, 2 females, 29.12.1965, leg. J. Loksa (NHMH, UIC); Santa Catarina, Linha Facão, 2 males, May 1954, leg. F. Plaumann (KNHM).

Diagnosis: The species resembles O. bicolor, O. levyi, O. salvini, and O.flaveolus. It is slightly smaller than O. salvini and O.flaveolus. According to the pronotal punctation it is intermediate between O. levyi and O. bicolor. The punctation is slightly denser than in O. levyi, but sparser and less deep than in O. bicolor. The three species can be differentiated mainly be the shape of the apical lobe of the aedeagus. In O. levyi the apical lobe is ending in an acute apex, whereas it is ending in an obtuse apex in O. bicolor and O. loksai.

Description: Length: 3.3 - 3.4 mm. Colouration: Reddish; posterior margin of pronotum and suture of elytra lighter reddish; legs and antennae yellow.

Head: $0.46 \mathrm{~mm}$ long, $0.65 \mathrm{~mm}$ wide; eyes small and not prominent; temples nearly 1.5 times as long as eyes; sides of fore-head moderately sinuate; sides of clypeus parallel; front edge of clypeus even without lateral teeth; setiferous punctation moderately deep and dense, but with large area at base of antennae and wide midline impunctate; on vertex, interstices between punctures shorter than half of diameter of punctures; partly coriaceous, in particular, on supraocular area; without microsculpture; surface polished and shiny.

Antennae as long as head and half of pronotum combined; second antennomere oblong; thicker and longer than conical third antennomere; fourth to sixth antennomeres not wider than third, but quadrate or shortly wider than long; seventh to tenth antennomeres thicker than preceding antennomeres; penultimate antennomere nearly twice as wide as long.

Pronotum: $0.64 \mathrm{~mm}$ long, $0.64 \mathrm{~mm}$ wide; widest at anterior angles; slightly and evenly narrowed to posterior angles; in posterior third more distinctly convergent than in anterior two-third; posterior angles widely rounded; 
lateral margin extremely fine, but visible throughout its total length; setiferous punctation moderately dense and deep; in irregular rows; interstices between punctures within rows half as wide as diameter of puncture; interstices between adjacent rows as wide as diameter of punctures; with wide midline impunctate; moderately dense micro-punctation; remains of weak microsculpture; surface nearly polished and shiny.

Elytra: $0.69 \mathrm{~mm}$ long, $0.65 \mathrm{~mm}$ wide; weak coriaceous ground-sculpture; setiferous punctation in irregular rows; punctures distinctly visible within ground-sculpture; surface shiny.

Abdomen with dense setiferous punctation and wide impunctate midline on tergites; without microsculpture; surface polished and shiny.

Protibia: $0.40 \mathrm{~mm}$ long, $0.14 \mathrm{~mm}$ wide; 9 spines on outer edge; apical 2 spines on short digits; WLR: 2.60; in posterior aspect, comb at inner emargination visible throughout its total length; posterior face with moderately dense setation.

Aedeagus with long and slender apical lobe ending in obtuse apex; at inner edge of apical lobe with 4 sensillae.

Etymology: The species is named in honour of its collector Dr. I. Loksa.

\section{Osoriellus luteus n. sp.}

(Figs 46A-C, 94D)

Type material: Holotype, male: Peru: Huánuco, Panguana (7455.58'W, 9³6.55'S), forest, April/May 1975, leg. W. Hanagarth (UIC).

Paratypes: Peru: Huánuco, Panguana $\left(74^{\circ} 55.58^{\prime} \mathrm{W}\right.$, $9^{\circ} 36.55$ 'S), forest, female, Feb. 1975, leg. W. Hanagarth; river margin, female, 6.5.1976, leg. W. Hanagarth; clear cut forest, female, Jun.-Jul. 1975, leg. W. Hanagarth (UIC); Brazil: Pará, $5 \mathrm{~km}$ E. Belém, soil litter layer in primary forest, male, 26.04.1976, leg. R.T. Schuh (AMNH); French Guyana: Roura, $18.4 \mathrm{~km}$ SSE $\left(52^{\circ} 13.25^{\prime} \mathrm{W}\right.$, $\left.4^{\circ} 36.38^{\prime} \mathrm{N}\right), 240 \mathrm{~m}$ elevation, ex. flight intercept trap, male, 25.-29.5.1997, leg. J.S. Ashe \& R. Brooks, \#FG1AB97 081 (KNHM).

Diagnosis: The species resembles O. exiguus and O. coruscus in size, but it can be easily differentiated from these species by the slightly prominent eyes. Concerning the shape of the head O. luteus resembles O. ocularis, but the eyes are less prominent and total size is smaller.

Description: Length: $2.8 \mathrm{~mm}$. Colouration: Head brown; pronotum reddish; elytra and abdomen still lighter yellow; with darker spot in posterior half of elytra and on abdominal segments VI and VII.

Head: $0.33 \mathrm{~mm}$ long, $0.53 \mathrm{~mm}$ wide; with large and slightly prominent eyes; eyes as long as temples; area between eyes 9 times as wide as diameter of eyes; sides of fore-head sinuate and shortly convergent to anterior angles; anterior edge even; angles produced to short granules; setiferous punctures large and deep; punctation on vertex dense, but slightly finer and sparser than on clypeus; yellow setae pointing to middle; wide midline impunctate; with distinct netlike microsculpture; surface matt.

Antennae with first antennomere slightly longer than 2 following antennomeres combined; second antennomere globular; third antennomere conical and slightly shorter than second; the following 3 antennomeres quadrate and not wider than preceding antennomeres; last 5 antennomeres thicker and approximately quadrate.

Pronotum: $0.55 \mathrm{~mm}$ long, $0.60 \mathrm{~mm}$ wide; widest at anterior angles; slightly convergent to posterior angles; sides in anterior three-fourth nearly parallel; in front of posterior angles sinuate; lateral margin fine; in dorsal aspect, not visible in anterior half; setiferous punctation large and deep; moderately dense; along impunctate midline punctures in irregular rows; yellow setae pointing to middle; without microsculpture, but with extremely fine micro-punctation; surface polished and shiny.

Elytra: $0.65 \mathrm{~mm}$ long, $0.60 \mathrm{~mm}$ wide; with coriaceous ground-sculpture; setiferous punctation deep and large, but nearly invisible between ground-sculpture; yellow setae pointing to middle.

Abdomen deeply and densely punctate; setae pointing to middle.

Protibia: $0.35 \mathrm{~mm}$ long, $0.10 \mathrm{~mm}$ wide; 9 long spines at outer edge; WLR: 4.30; in posterior aspect, inner edge only slightly emarginate and comb partly covered in middle; posterior face with sparse setation.

Aedeagus with long and straight basal lobe and short smoothly curved apical lobe ending in acute apex.

Etymology: The specific name luteus derived from the same Latin word meaning yellow and refers to the yellow colouration of the elytra and the abdomen.

\section{Osoriellus majusculus n. sp. \\ (Figs 91A-C, 99F)}

Type material: Holotype, male: Peru: Tambopata Prov., Madre de Dios Dept, $15 \mathrm{~km}$ NE Puerto Maldonado, Reserva Cuzco Amazónico (69 03'W, 12²2'S), $200 \mathrm{~m}$ elevation, collected by flight intercept trap, Plot \#Z1 rail 26, male, 16.7.1989, leg. J.S. Ashe \& R.A. Leschen, \#519 (KNHM).

Diagnosis: O. majusculus is one of the largest species in the O.-s. str.-group. It is characterised by the wide lateral margin at the posterior pronotal angles. In the similarly sized $O$. parcus the lateral pronotal margin is narrow. A slightly widened lateral pronotal margin is also found in O. fumarius and O. caliginosus, but these species are smaller and the pronotal sides are more deeply sinuate. 
Description: Length: $6.7 \mathrm{~mm}$. Colouration: Black; elytra reddish brown; legs dark brown; antennae lighter brown. Head: $0.91 \mathrm{~mm}$ long, $1.40 \mathrm{~mm}$ wide; eyes slightly prominent; as long as temples; fore-head deeply emarginate; sides of clypeus nearly parallel; anterior edge of clypeus slightly sinuate with acute angles shortly produced; setiferous punctation sparse and moderately deep; irregular midline and moderately large area at base of antennae impunctate; punctation of clypeus sparser than on vertex; interstices between punctures wider than diameter of punctures; punctation of vertex irregular; on average, interstices between punctures as wide as diameter of punctures; on supraocular area punctation still denser and partly granulate; isodiametric microsculpture dense and distinct; surface matt.

Antennae slightly longer than head; second antennomere oval; third conical and as long as second; antennomeres four to six as wide as third, but quadrate; following antennomeres wider than preceding antennomeres and also quadrate; last antennomere elongate.

Pronotum: $1.40 \mathrm{~mm}$ long, $1.53 \mathrm{~mm}$ wide; widest near anterior angles; evenly narrowed to posterior angles; slight emargination in posterior half; posterior angles approximately rectangular; lateral margin fine in anterior half, slightly wider in posterior half; shortly in front of posterior angles widened; in dorsal aspect, covered close to anterior angles; setiferous punctation dense and deep with narrow impunctate midline; on average, interstices between punctures slightly wider than diameter of punctures; isodiametric microsculpture deep; surfcae matt.

Elytra: $1.74 \mathrm{~mm}$ long, $1.65 \mathrm{~mm}$ wide; nearly parallel; setiferous punctation distinct; coriaceous ground-sculpture weak; punctures finer and sparser than on pronotum. Abdomen with dense setiferous punctation; isodiametric microsculpture dense; surface matt.

Protibia: $0.79 \mathrm{~mm}$ long, $0.29 \mathrm{~mm}$ wide; nearly semicircular; 9 spines on outer edge; apical spines inserted on short digits; WLR: 1.53; in posterior aspect, comb of inner emargination visible throughout its total length; posterior face densely covered by long yellow setae.

Aedeagus angulate in nearly rectangular angle; basal lobe nearly as long as apical lobe; apical lobe thick in basal half; in apical third suddenly narrowed to obtuse apex; row of numerous sensillae on inner edge of apical lobe.

Etymology: The specific word majusculus derived from the same Latin word and means slightly larger. It refers to the relatively large size of the species.

\section{Osoriellus mexicanus (BernhaUeR, 1910) new combination \\ (Figs 75A-B, 99B)}

Osorius mexicanus BERNHAUER, 1910: 371

Type material examined: Mexico: Oaxaca, Mitla, $96^{\circ} 17^{\prime} \mathrm{E}$, $16^{\circ} 54^{\prime} \mathrm{N}$, female (holotype in FMNH).
Further material examined: Mexico: Tepic, Nayarit, female, 2.-7.8.1947, leg. B. Malikin (AMNH); Real de Arriba $\left(93^{\circ} 52^{\prime} \mathrm{W}, 16^{\circ} 13^{\prime} \mathrm{N}\right), 3$ females, 1.7.1932, leg. H.E. Hinton (AMNH); San Luis Potosi, Xilitla, 23.7.1954, leg. Univ. Kansas Mex. Expedition (KNHM); Guatemala: Baja Verapaz, 4 km SW Purulha, 1700 - 1800 m elevation, biotope del Quetzal, under stones and pieces of wood, cloud forest, female, 27.11.1991, leg. R. Baranowski (SMNH); Antigua, $5 \mathrm{~km} \mathrm{E,} 1780 \mathrm{~m}$ elevation sifting litter, tropical montane forest, female, 7.11.1991, leg. R. Baranowski (UIC).

Diagnosis: The species is very similar to $O$. cordovensis in the size, the shape of the pronotum and the absence of microsculpture on head and pronotum. It can be differentiated from $O$. cordovensis by the sparser, but larger punctures of the pronotum and the absence of digits on the outer edge of the protibia. It differs from O. brevipennis by the less triangular shape of the pronotum. It highly coincides with $O$. argentinus. But $O$. argentinus has at least remains of microsculpture on the head, whereas the head of O. mexicanus is without microsculpture and polished.

Description: Length: $5.1 \mathrm{~mm}$; Colouration: Dark red; elytra lighter red than head and pronotum; abdomen distinctly darker; front legs red; middle and hind legs as well as antennae yellow.

Head: $0.60 \mathrm{~mm}$ long, $1.00 \mathrm{~mm}$ wide; eyes as long as temples; front edge of clypeus even with short acute granules at angles; with deep and large setiferous punctures; interstices between punctures much shorter than diameter of punctures; punctation on clypeus less dense than on vertex; moderately wide midline impunctate; between coarse punctures with sparse micro-punctation; on supraocular area with partly coriaceous punctation; on vertex without microsculpture; surface polished; on supraocular and postocular area with dense longitudinally reticulate microsculpture; surface matt.

Antennae with second and third antennomeres equally long; fourth to sixth antennomeres quadrate; following antennomeres much thicker than preceding antennomeres and wider than long.

Pronotum: $1.00 \mathrm{~m}$ long, $1.10 \mathrm{~mm}$ wide; widest at anterior edge; distinctly and evenly convergent to posterior angles; posterior edge nearly half as wide as anterior edge; setiferous punctation deep, but distinctly sparser than on head; interstices between punctures as wide as or slightly wider than diameter of punctures; on each side of impunctate midline with row of 6 punctures; between coarse punctures with sparse micro-punctation; surface without microsculpture, polished.

Elytra: $1.05 \mathrm{~mm}$ long, $1.05 \mathrm{~mm}$ wide; with coriaceous ground-sculpture and weak and sparse setiferous punctation; punctures nearly invisible in deep ground-sculpture; surface shiny.

Abdomen deeply and densely punctate; on average, interstices between punctures shorter than diameter of 
punctures except on relatively small impunctate midline; surface without microsculpture, shiny.

Protibia: $0.73 \mathrm{~mm}$ long, $0.23 \mathrm{~mm}$ wide; 10 spines at outer edge; spines not inserted on digits; WLR: 6,0; in posterior aspect, comb at inner emargination visible throughout its total length; posterior face densely covered by long setae. Aedeagus unknown.

\section{Osoriellus micros (SHARP, 1887) new combination (Figs 54A-C, 95E)}

Osorius micros SHARP, 1887: 682

Type material examined: Panama: San Felix, leg. Champion (holotype in $\mathrm{BMNH}$ ).

Further material examined: Mexico: Real de Arriba $\left(93^{\circ} 52^{\prime} \mathrm{W}, 16^{\circ} 13^{\prime} \mathrm{N}\right)$, Temescaltepec, 1 female, 7.1934, leg. H.E. Hinton (AMNH); Tamaulipas $\left(98^{\circ} 55.50^{\prime} \mathrm{W}\right.$, $\left.21^{\circ} 09.56^{\prime} \mathrm{N}\right)$, Rancho del Cielo, Gomes Farias, $1230 \mathrm{~m}$ elevation, 1 male, 4.7.1969, leg. J. Peck (AMNH); Palenque, 26.-28.3.1974, leg. C. Alteri (UIC); El Naranjo, 3.1.1950, leg. L.D. Beamer (KNHM); Guatemala: San José de Guatemala $\left(90^{\circ} 49^{\prime} \mathrm{W}, 13^{\circ} 55^{\prime} \mathrm{N}\right), 8$ specimens, 22.01. 1930, leg. R.E. Blackwelder (AMNH, UIC); El Salvador: La Libertad $\left(89^{\circ} 19^{\prime} \mathrm{W}, 13^{\circ} 29^{\prime} \mathrm{N}\right)$; 1 female, 24.1.1930, leg. R.E. Blackwelder (AMNH); Nicaragua: Granada, Res. Nat. Volcan Mombacho (85 $\left.56.8^{\prime} \mathrm{W}, 11^{\circ} 50.0^{\prime} \mathrm{N}\right)$, $1150 \mathrm{~m}$ elevation, flight interc., 3 specimens, 2.-5.6.2002, leg. R.W. Brooks (KNHM); Costa Rica: Guanacaste, Guanacaste Conservation Area, Cacao Field Station $\left(85^{\circ} 27.0^{\prime} \mathrm{W}, 10^{\circ} 56.0^{\prime} \mathrm{N}\right), 1200 \mathrm{~m}$ elevation, sampled in wet montane forest litter, 6 males, 3 females 12.2.1996, leg. R. Anderson, \#CR1 A96 006C (KNHM); 1 male, 1 female, 15.2.1996, 3 males, 20.2.1996, 1 female, 14.2.1996, leg. R. Anderson (KNHM); from same location, 1100$1200 \mathrm{~m}$ elevation, sampled leaf litter by berlese method, 1 male, 2 females, 4.5.1995, leg. R. Anderson (KNHM); Maritza Biological Station, $550 \mathrm{~m}$ elevation, flight interc., 1 specimen, 22.5.1993, leg. J.S. Ashe (KNHM); San José, Cerro Chompipe, $2 \mathrm{~km}$ N Monte de la Cruz $\left(84^{\circ} 9.0^{\prime} \mathrm{W}\right.$, $\left.9^{\circ} 53.30^{\prime} \mathrm{N}\right), 2000 \mathrm{~m}$ elevation, female, 13.6.1997, leg. R. Anderson (KNHM); Pan American Hwy km 117, $19 \mathrm{~km} \mathrm{~N}$. S. Isidro, $1800 \mathrm{~m}$ elevation, flight interc., 2 specimens, 20.-25.6.1997, J. Peck (KNHM); Puntarenas, Las Alturas, Biol. Sta. $\left(82^{\circ} 50.01^{\prime} \mathrm{W}, 8^{\circ} 56.17^{\prime} \mathrm{N}\right)$, 1660 m elevation, sampled by flight intercept trap, $4 \mathrm{spec}-$ imens, 31.5-3.6.2004, leg. J.S. Ashe, Z. Falin, I. Hinojosa (KNHM); Puntaraneas, Reserva Biologica del Carara, nr. Rio Grande del Tarcoles $\left(84^{\circ} 30^{\prime} \mathrm{W}, 9^{\circ} 51^{\prime} \mathrm{N}\right), 2$ males, 14.2.1989, leg. Grimaldi \& de Vries (AMNH); Puntarenas, Rincon de Osa, male, 14.-26.7.1969, leg. T. Schuh \& J. Crane (AMNH); Rincon de Osa, 7 km W. Osa Penn, Est. F.N. Aguas Buenas, $50 \mathrm{~m}$ elevation, flight interc., 1 specimen, 25.6.1997, leg. J. Peck (KNHM); Monteverde Reserve, flight interc., 6 specimens, 26.-28.5.1993,
30.5.1993, 1.6.1993, leg. C. Michalski (KNHM); same location, 6 specimens, 16.5., 21.5.1989, leg. J. Ashe, R. Brooks \& R. Leschen (KNHM); same location, upper Laval's wood site, Quebrada Máquina, $1400 \mathrm{~m}$ elevation, flight interc., 2 specimens, 21.5.1989, leg. J.S. Ashe, R. Leschen \& R. Brooks (KNHM); same location, 1 specimen, 28.-31.5.1992, leg. M. Jameson (KNHM); $11 \mathrm{~km} \mathrm{SW}$ Biol Stn Las Cruzes $\left(83^{\circ} 01.50^{\prime} \mathrm{W}, 8^{\circ} 46.43^{\prime} \mathrm{N}\right)$, wet cloud forest litter, $1450 \mathrm{~m}$ elevation, 2 specimens, 9.7.1999, leg. R. Anderson (KNHM); Reserva Biologia Carara, nr. Rio Grande del Tarcoles, 1 specimen, 14.2.1989, leg. D.A. Grimaldi (KNHM); Heredia, Puerto Viejo, $3 \mathrm{~km} \mathrm{~S}$, La Selva $\left(84^{\circ} 0.0^{\prime} \mathrm{W}, 10^{\circ} 25.0^{\prime} \mathrm{N}\right)$, flight interc., 6 specimens, 2.-15.6.1996, leg. R. Hanley (KNHM); $3.2 \mathrm{~km} \mathrm{SE,} \mathrm{La}$ Selva, $100 \mathrm{~m}$ elevation, flight interc., 8 specimens, 14.2., 24.2., 28.2., 3.3., 6.3., 17.3., 19.3., 24.3.1992, leg. W. Bell (KNHM); Alajuela, San Ramon, 27 km N., 8 km W, montane forest $\left(84^{\circ} 35.30^{\prime} \mathrm{W}, 10^{\circ} 13.30^{\prime} \mathrm{N}\right), 1120 \mathrm{~m}$ elevation, 3 specimens, 29.6.-6.7.1999, leg. R. Anderson (KNHM); Puntarenas, Rincon de Osa, Rd. Bahia Drake Rincon, devastated forest, plantations, 0-400 m elevation $\left(83^{\circ} 29^{\prime} \mathrm{W}, 8^{\circ} 41^{\prime} \mathrm{N}\right)$, car net, 1 male, 1 female, 9.12.2012, leg. M. Schülke \& Grünberg (MSC, UIC); Rd. BanigonesChacarita, pastures, plantages, devasted forest, 0-250 m elevation $\left(83^{\circ} 15^{\prime} \mathrm{W}, 8^{\circ} 36^{\prime} \mathrm{N}\right)$, car net, female, 11.12.2012, leg. M. Schülke \& Grünberg (UIC); Guanacaste, Liberia, Rd. to Hacienda Guachipelin, 135-530 m elevation $\left(85^{\circ} 22^{\prime} \mathrm{W}, 10^{\circ} 39^{\prime} \mathrm{N}\right)$, car net, 3 females, 5.12.2012, leg. M. Schülke \& Grünberg (MSC, UIC); Panama: Chiriqui, $5.6 \mathrm{~km} \mathrm{~N}$ Boquete, La Culebra Trail $\left(82^{\circ} 25.18^{\prime} \mathrm{W}\right.$, $\left.8^{\circ} 49.23^{\prime} \mathrm{N}\right), \quad 1400 \mathrm{~m}$ elevation, sampled from oak forest litter, female, male, 19.6.1996, leg. R. Anderson, \#PAN2A9696-141A (KNHM); Colon, Parque National Soberania Pipeline Rd. km $6.1\left(79^{\circ} 45^{\prime} \mathrm{W}, 9^{\circ} 07^{\prime} \mathrm{N}\right)$, sampled by flight intercept trap, 5 specimens, 4-7.6., 7.-21.6.1995, leg. J. Ashe, R. Brooks (KNHM, UIC); same location, Pipeline Rd. $\mathrm{km} 2.0\left(79^{\circ} 45^{\prime} \mathrm{W}, 9^{\circ} 07^{\prime} \mathrm{N}\right)$, flight interc., 1 specimen, 29.5.1995, leg. J. Jolly \& C. Chaboo (KNHM); La Fortuna, Cont. Divide Trail $\left(82^{\circ} 12^{\prime} \mathrm{W}, 8^{\circ} 46^{\prime} \mathrm{N}\right)$, flight intercept trap, 2 specimens, 23.5.-9.6., 9.-12.6.1995, leg. J. Ashe \& R. Brooks (KNHM); Darién, Cana Biol. Station $\left(77^{\circ} 41.6^{\prime} \mathrm{W}, 7^{\circ} 45.18^{\prime} \mathrm{N}\right), 530 \mathrm{~m}$ elevation, flight intercept trap, 2 specimens, 3.-7.6.1996, leg. J.A. Ashe \& R. Brooks (KNHM); Cana Biol. Stat., Serrania de Pirre $\left(77^{\circ} 41.6^{\prime} \mathrm{W}\right.$, $\left.7^{\circ} 45.18^{\prime} \mathrm{N}\right), 1250 \mathrm{~m}$ elevation, flight interc., 5 specimens, 4.-7.6., 7.-9.6.1996, leg. J.S. Ashe \& R. Brooks (KNHM); Gualaca, $20 \mathrm{~km}$ N,Finca La Suiza $\left(82^{\circ} 12^{\prime} \mathrm{W}, 8^{\circ} 39^{\prime} \mathrm{N}\right)$, 1350 m elevation, flight interc., 1 specimen, 22.-24.5.1995, leg. J.S. Ashe (KNHM); Panama, $15 \mathrm{~km} \mathrm{~N} \mathrm{EL} \mathrm{Llano}$ (Carti Rd.), 1 specimen, 10.05.1981, leg. R.W. Brooks (KNHM); Cuba: Cayamas $\left(80^{\circ} 34^{\prime} \mathrm{W}, 22^{\circ} 16^{\prime} \mathrm{N}\right), 1$ male, leg. E.A. Schwarz (AMNH); Saint Lucia: Castries Marigot Harbor $\left(61^{\circ} 01.29^{\prime} \mathrm{W}, 13^{\circ} 57.41^{\prime} \mathrm{N}\right), 1$ female, 17.7.1980, leg. L.S. Mahunka (NHMH); Ecuador: Sucumbios Prov. Sacha Lodge $\left(76^{\circ} 05^{\prime} \mathrm{W}, 0^{\circ} .05^{\prime} \mathrm{S}\right), 270 \mathrm{~m}$ elevation, Malaise trap, female, 24.5.-3.6.1994, leg. Hibbs (KNHM); Sacha Lodge, 250 m, flight interc., 1 specimen, 28.10.2004, leg. G. de Rougemont (UIC). 
Diagnosis: The species resembles O. bicolor and O. lewisi in size and punctation. It can be easily differentiated from O. bicolor by the netlike microsculpture of the pronotum. The differences to the similar O. lewisi are mentioned there.

Description: Length: $3.5 \mathrm{~mm}$. Colouration: Dark reddish to light brown; legs and antennae reddish.

Head: $0.50 \mathrm{~mm}$ long, $0.60 \mathrm{~mm}$ wide; eyes slightly prominent; anterior edge of clypeus slightly emarginate; without granules at angles; setiferous punctures large and dense; interstices between punctures one-fourth as wide as diameter of punctures or slightly shorter; moderately wide impunctate midline; netlike microsculpture fine, but distinct; surface slightly shiny.

Antennae with oblong second antennomere and conical third; third antennomere not longer than second; fourth antennomere quadrate; following two antennomeres slightly wider than long; antennomeres 7 to 10 distinctly thicker than preceding antennomeres; slightly wider than long.

Pronotum: $0.70 \mathrm{~mm}$ long, $0.70 \mathrm{~mm}$ wide; widest at anterior angles; evenly convergent to posterior angels; posterior angles obtusely rounded; lateral margin fine; invisible at anterior angles in dorsal aspect; setiferous punctures very large and deep; still larger than on head; on disc in irregular rows of 6 to 8 punctures; interstices between punctures one-fourth as wide as diameter of punctures; microsculpture netlike; surface slightly shiny.

Elytra: $0.85 \mathrm{~mm}$ long, $0.70 \mathrm{~mm}$ wide; with deep and large punctures; partly coriaceous; surface with irregular microsculpture; slightly shiny.

Abdomen with dense setiferous punctation and moderately wide impunctate midline; isodiametric microsculpture distinct; surface slightly shiny.

Protibia: $0.43 \mathrm{~mm}$ long, $0.15 \mathrm{~mm}$ wide; 9 spines on outer edge; apical 2 spines on very short digits; WLR: 2.5; in posterior aspect, comb at inner emargination partly covered in apical half; posterior face with moderately dense setation; setae nearly half as long as protibial width.

Aedeagus slender; apical lobe straight; in apical half rectangularly angulate; apex widely obtuse; inner edge of apical lobe with three pairs of sensillae.

\section{Osoriellus minor (NotMAN, 1925) new combination} (Figs 69A-C, 97F)

Osorius minor Notman, 1925: 4

Type material examined: Trinidad: Montserrat, 1 female, 30. June 1905, leg. A. Busck (holotype in NHMW).

Further material examined: Mexico: Quintana $\left(87^{\circ} 35^{\prime} \mathrm{W}\right.$, $\left.19^{\circ} 46^{\prime} \mathrm{N}\right), 12 \mathrm{~km} \mathrm{~N}$ Reforma, male, 14.10.1986, G. Rozen $(\mathrm{AMNH})$.
Diagnosis: Among the similarly sized species of the O.-s. str.-group, O. minor is characterised by the absence of microsculpture on the pronotum and the dense setiferous punctation. In this respect, it resembles O. tuxtlae, but the pronotal sides are curved in O. minor, whereas they are forming a more trapezoidal shape in O. tuxtlae. The aedeagus of $O$. minor has a smoothly curved short apical lobe; whereas the aedeagus of $O$. tuxtlae is rectangularly angulate.

Description: Length: $4.8 \mathrm{~mm}$. Colouration: Black; legs and antennae brown; posterior edge of pronotum dark reddish

Head: $0.61 \mathrm{~mm}$ long, $0.94 \mathrm{~mm}$ wide; eyes slightly prominent; approximately twice as long as temples; angles of clypeus produced to short granules; setiferous punctation moderately dense and deep; posteriorly and laterally much denser than on clypeus; on clypeus, interstices between punctures at least twice as wide as diameter of punctures; on posterior vertex interstices between punctures shorter than diameter of punctures; supraocular punctures more distinctly granulate than punctures on vertex; few supraocular short striae; isodiametric microsculpture dense and distinct; surface slightly shiny.

Antennae with oval second and conical third antennomere equally long; following three antennomeres quadrate or slightly wider than long; last five antennomeres distinctly thicker than preceding antennomeres, but more or less quadrate.

Pronotum: $0.93 \mathrm{~mm}$ long, $1.00 \mathrm{~mm}$ wide; widest near anterior angles; evenly convergent to obtuse posterior angles; lateral margin fine; large setiferous punctures in irregular rows; on average, interstices between punctures half as wide as diameter of punctures; narrow midline impunctate; surface with weak netlike microsculpture; microsculpture less deep than on head and surface more shiny.

Elytra: $1.04 \mathrm{~mm}$ long, $1.04 \mathrm{~mm}$ wide; large setiferous punctures hardly visible between deep coriaceous ground-sculpture; punctures in irregular rows.

Abdomen with dense and deep setiferous punctation; isodiametric microsculpture distinct and similar as on head; microsculpture more distinct than on pronotum.

Protibia: $0.50 \mathrm{~mm}$ long, $0.17 \mathrm{~mm}$ wide; 8 spines on outer edge; apical spines inserted on short digits; WLR: 2.10; in posterior aspect, comb of inner emargination totally visible; posterior face with dense setation.

Aedeagus slender; apical lobe straight; slightly curved in nearly rectangular angle to acute apex; inner edge of apical lobe with row of several sensillae.

\section{Osoriellus multipunctatus $\mathrm{n}$. sp.}

(Figs 87A-C, 101C)

Type material: Holotype, male: Ecuador: Pichincha, Mindo, $10.6 \mathrm{~km}$ W. Mindo Road $\left(78^{\circ} 45.14^{\prime} \mathrm{W}, 0^{\circ} 04.23^{\prime} \mathrm{S}\right)$, 1375 m elevation, 26.-29.3.1999, leg. R. Brooks, D. Brzoska, \#ECU1899065, ex. flight intercept trap (KNHM). 
Paratype: Bolivia: Cochabamba, Cochabamba, $109 \mathrm{~km}$ E Yungas (Cochabamba-Villa Tunari Rd.) $\left(65^{\circ} 42.54^{\prime} \mathrm{W}\right.$, $\left.17^{\circ} 08.52^{\prime} \mathrm{S}\right)$, flight intercept trap, female, 8.-12.2.1999, leg. F. Genier, \#BOL1G99060 (UIC).

Diagnosis: The species can be differentiated from the other similarily sized species by the large prominent eyes and the densely punctate pronotum. It closely resembles O. triangulatus. But the eyes in O. triangulatus are not prominent, the punctation of the pronotum is less dense and the shape of the body is more slender than in O. multipunctatus.

Description: Length: $4.8 \mathrm{~mm}$. Colouration: Dark brown, legs and antennae lighter brown.

Head: $0.57 \mathrm{~mm}$ long, $0.97 \mathrm{~mm}$ wide; eyes large; twice as long as temples; sides of fore-head strongly convergent; anterior edge of clypeus only half as wide as interstice between eyes; anterior edge of clypeus even; setiferous punctation coarse and dense; on average, interstices between punctures less than half as wide as diameter of punctures; short central area on posterior vertex and at base of antennae impunctate; netlike microsculpture dense and distinct; surface slightly shiny.

Antennae longer than head and half of pronotum combined; second antennomere oblong; third conical and as long as second; fourth antennomere slightly longer than wide; following antennomeres increasing in width, but all quadrate.

Pronotum: $0.90 \mathrm{~mm}$ long, $0.99 \mathrm{~mm}$ wide; widest shortly behind anterior angles; anterior angles produced to extremely short acute granules; sides evenly convergent to widely ronded posterior angles; lateral margin fine; in dorsal aspect, visible throughout its total length; setiferous punctation coarse and dense, but not coriaceous; on average, interstices between punctures less than half as wide as diameter of punctures; wide midline impunctate; between setiferous punctures with sparse micro-punctation; netlike microsculpture weaker than on head; surface slightly shiny.

Elytra: $1.13 \mathrm{~mm}$ long, $1.09 \mathrm{~mm}$ wide; with dense coriaceous ground-sculpture; dense setiferous punctation nearly invisible in ground-sculpture.

Abdomen with moderately dense setiferous punctation; netlike microsculpture still weaker than on pronotum; surface moderately shiny.

Protibia: $0.58 \mathrm{~mm}$ long, $0.18 \mathrm{~mm}$ wide; 9 spines on outer edge; WLR: 1.70; in posterior aspect, comb at inner emargination shortly covered in central part; posterior face densely coverd by yellow setae.

Aedeagus with moderately thick apical lobe ending in obtuse apex; seven sensillae at inner edge of apical lobe.

Etymology: The specific word is a combination of the Latin words multi meaning many and punctatus meaning punctate and refers to the densely punctate pronotum.

\section{Osoriellus obtusicollis n. sp.}

(Figs 65A-C, 96C)

Type material: Holotype, male: Guatemala: San José, 22.1.1930, leg. R.E. Blackwelder (AMNH).

Paratypes: Cuba: Prov. Havana, Cotorro $\left(82^{\circ} 13^{\prime} \mathrm{W}\right.$, $23^{\circ} 01^{\prime} \mathrm{N}$ ), luz, female, 9.1998, leg. A. Lozada (IES); Peru: Junin, Satipo $\left(74^{\circ} 38.20^{\prime} \mathrm{W}, 11^{\circ} 15.25 S\right)$, Puerto Miranda, male, 23.01.1984, L. Huggert (SMNH).

Diagnosis: Among the similarly sized species, O. obtusicollis can be identified by the weak microsculpture and the specific shape of the pronotum. Compared to O. flaveolus, the pronotal punctation is coarser and denser and the lateral margin finer, in particular, near the posterior angles. In O. salvini, the pronotal microsculpture is still weaker, the surface nearly polished and the shape of the pronotum is more trapezoidal. Furthermore, the clypeus of $O$. salvini has short granulate angles, whereas in O. obtusicollis clypeal granules are totally absent.

Description: Length: $3.5 \mathrm{~mm}$. Colouration: Brown; pronotum lighter brown; elytra red; legs and antennae yellow.

Head: $0.50 \mathrm{~mm}$ long, $0.69 \mathrm{~mm}$ wide; eyes not prominent; as long as temples; sides of fore-head concavely convergent to anterior angles; anterior edge of clypeus even without lateral granules; setiferous punctation coarse; midline on fore-head and small area at base of antennae impunctate; on vertex punctation dense; on average, interstices between punctures half as wide as diameter of punctures; netlike microsculpture weak; surface slightly shiny.

Antennae slightly shorter than head and half of pronotum combined; second antennomere oval and distinctly longer than conical third; antennomeres 4 to 6 as wide as third, but shorter; antennomeres 4 and 5 approximately quadrate; antennomere 61.5 times as wide as long; antennomeres 7 to 10 much wider than preceding antennomeres and slightly wider than long.

Pronotum: $0.71 \mathrm{~mm}$ long, $0.72 \mathrm{~mm}$ wide; widest at anterior angles; anterior angles obtuse and smoothly rounded; sides slightly narrowed to posterior angles; in posterior half more strongly convergent than in anterior half; posterior angles obtusely rounded; lateral margin fine; in dorsal aspect visible throughout its total length except in small part close to anterior angles; irregularly dense setiferous punctation coarse; in irregular rows; interstices between punctures rangeing between half as wide to twice as wide as diameter of punctures; between coarse punctation with sparse micro-punctation; netlike microsculpture weak; surface slightly shiny.

Elytra: $0.82 \mathrm{~mm}$ long, $0.75 \mathrm{~mm}$ wide; with dense rows of setiferous punctures on coriaceous ground-sculpture; surface matter than on head and pronotum.

Abdomen with dense and coarse setiferous punctation except narrow impunctate midline; weak netlike microsculpture; surface slightly shiny. 
Protibia: $0.44 \mathrm{~mm}$ long, $0.16 \mathrm{~mm}$ wide; thick and wide; 11 spines at outer edge; WLR: 3.30; in posterior aspect, comb at inner edge not visible in small central part; posterior face densely covered by yellow setae.

Aedeagus with short apical lobe ending in widely obtuse apex; five sensillae at inner edge of apical lobe.

Etymology: The specific name is a combination of the Latin words obtusus meaning obtuse and collis meaning pronotum and refers to the smoothly rounded shape of the pronotum.

\section{Osoriellus opacus n. sp.}

(Figs 83A-C, 100B)

Type material: Holotype, male: Belize: Orange Walk District, Rio Bravo Conservation Area, Area along Mahogony Trail $\left(17^{\circ} 50^{\prime} \mathrm{N}, 8^{\circ} 01^{\prime} \mathrm{W}\right)$, collected by berlese method, 18.4.1996, leg. C. Carlton \& V. Moseley (KMNH).

Paratypes: Belize: Orange Walk Distr., La Milpa Field Station, flight intercept trap, female, 25.05.1997, leg. C.E. Carlton \#FIT5, Lot\#152 (UIC); Chiquibul Forest Res. Las Cuevas field station $\left(88^{\circ} 59^{\prime} \mathrm{W}, 16^{\circ} 44^{\prime} \mathrm{N}\right), 500-700 \mathrm{~m}$ elevation, 2 males, June 1997, leg. D. Inward (BMNH); Cayo, Las Cuevas Research Station $\left(88^{\circ} 58.24^{\prime} \mathrm{W}\right.$, $\left.16^{\circ} 44.00^{\prime} \mathrm{N}\right), 550 \mathrm{~m}$ elevation, male, 22.-26.5.2000, leg M. Caterino (BMNH).

Diagnosis: The species is very similar to O. schwarzi in size and microsculpture of the head and the pronotum. The lengths of the antennomeres are also similar to O. schwarzi. Compared to O. opacinotus with a similarly matt pronotum, it can be distinguished by the absence of long digits of the protibia and the shinier elytra. It differs in the extreme dense and deep microsculpture of the elytra from both species. Furthermore, the aedeagus is characterised by the thick apical lobe and the numerous sensillae at the inner edge. The aedeagal apical lobes are more slender in O. schwarzi and O. opacinotus.

Description: Length: $5.8 \mathrm{~mm}$. Colouration: Black; legs and antennae light brown.

Head: $0.71 \mathrm{~mm}$ long, $1.13 \mathrm{~mm}$ wide; eyes not prominent; slightly longer than temples; sides of fore-head concavely convergent to anterior angles; anterior edge even except weak crenate structure at angles; setiferous punctation fine and moderately sparse; punctures on supraocular area denser and punctures partly granulate; without impunctate midline; isodiametric microsculpture dense and deep; surface matt.

Antennae with oblong second and conical third antennomeres slightly longer than wide; following antennomeres increasing in width; fourth and fifth antennomeres more or less quadrate; sixth antennomere slightly wider than long; following antennomeres thicker than preceding antennomeres, but quadrate.
Pronotum: $1.19 \mathrm{~mm}$ long, $1.31 \mathrm{~mm}$ wide; widest at anterior angles; evenly narrowed to posterior angles in smooth curve; lateral margin slightly widened to posterior angles and, in dorsal aspect, visible throughout its total length; irregular punctation deeper and larger than on head; with wide impunctate midline; interstices between punctures within irregular rows shorter than diameter of punctures; interstices of punctures between rows at least as wide as diameter of punctures; isodiametric microsculpture deep; surface matt.

Elytra: $1.23 \mathrm{~mm}$ long, $1.30 \mathrm{~mm}$ wide; with deep isodiametric microsculpture; microsculpture still deeper and denser than on pronotum; surface distinctly matter than on pronotum; punctation in irregular rows; nearly invisible in deep microsculpture.

Abdomen with weak netlike microsculpture; much weaker than on fore-body; setiferous punctation dense with impunctate midline.

Protibia: $0.71 \mathrm{~mm}$ long, $0.23 \mathrm{~mm}$ wide; 9 spines on outer edge; WLR: 2.30; in posterior aspect, comb of inner emargination visible throughout its total length; posterior face sparsely covered by yellow setae.

Aedeagus with thick apical lobe ending abruptly in obtuse apex; inner edge of apical lobe with numerous sensillae.

Etymology: The specific name opacus means matt and refers to the matt elytra.

\section{Osoriellus parcus (SHARP, 1887) new combination (Figs 80A-C, 99E)}

Osorius parcus SHARP, 1887: 680

Type material examined: Guatemala: Panzos $\left(89^{\circ} 37^{\prime} \mathrm{W}\right.$, $15^{\circ} 24^{\prime} \mathrm{N}$ ), 3 specimens, leg. Champion (syntypes in $\mathrm{BMNH})$.

Further material examined: Mexico: Mexico City $\left(99^{\circ} 07^{\prime} \mathrm{W}, 19^{\circ} 25^{\prime} \mathrm{N}\right)$, Desiertos de los Leones D.F. side Rio Mala, 1 specimen, 23.04.1946, leg. J. Pallister (AMNH); San Antonio $\left(92^{\circ} 46^{\prime} \mathrm{W}, 16^{\circ} 16^{\prime} \mathrm{N}\right)$, Volcan Tacaná, leaf litter beside Rio Mala, 9 specimens, 20.12.1976, leg. H. Frania (AMNH, UIC); Union Juarez, NW slope Vulc. Tacaná $\left(92^{\circ} 06^{\prime} 43^{\prime \prime} \mathrm{W}, 15^{\circ} 07^{\prime} 58^{\prime \prime} \mathrm{N}\right)$, Barranca Providencia, 1540 m elevation, 4 specimens, 25.12.1976, leaf litter flat area nr. stream, montane trop. forest, 1 specimen, 17.12.1975, Sumidero San Antonio, under moss and large rock, montane trop. forest, $1760 \mathrm{~m}$ elevation, 1 specimen, 20.12.1975, Pico Gallo, leaf litter, seepage area, montane trop. forest, $1700 \mathrm{~m}$ elevation, leg. H. Frania (AMNH); Tamaulipas (98 $\left.55^{\prime} 50^{\prime \prime} \mathrm{W}, 21^{\circ} 09^{\prime} 56^{\prime \prime} \mathrm{N}\right), 6 \mathrm{mi}$ NW Gomez Farias, Ranch del Cielo, human dung traps, $1230 \mathrm{~m}$ elevation, 1 specimen, 4.7.1969, leg. J. Peck (AMNH); Palenque $\left(91^{\circ} 58^{\prime} \mathrm{W}, 17^{\circ} 29^{\prime} \mathrm{N}\right)$, Ruines, stump litter, 1 specimen, 6.4.1974, leg. C. Alteri (AMNH); Chiapas, Volcan Tacaná, sumidero San Antonio, leaf litter beside Rio Mala, $1760 \mathrm{~m}$ elevation, male, 20.12.1976, 
leg. H. Frania (AMNH); Tamaulipas, shaded sand gravel banks of Nacimento Rio Frio, 4.5 mi SSE Gomez Farias, male, 4.01.1972, leg. H. Frania (AMNH); Chiapas, $2 \mathrm{mi}$ NE Tenejapa, $30 \mathrm{mi}$ ENE Tuxtla Gutierrez, in debris filled cracks of large rocks $\left(92^{\circ} 22^{\prime} \mathrm{W}, 16^{\circ} 50^{\prime} \mathrm{N}\right), 2300 \mathrm{~m}$ elevation, male 30.12.1972, leg. H. Frania (AMNH); Union Juarez $\left(92^{\circ} 04^{\prime} \mathrm{W}, 15^{\circ} 03 \mathrm{~N}\right), 4 \mathrm{~km} \mathrm{~N}$, lower slopes, cloud forest litter, $1950 \mathrm{~m}$ elevation, 16 specimens, 18.9.1992, leg. R. Anderson (KNHM, UIC); San Luis Potosi, Tlamaya (nr. Xilitla), 1 specimen, 01.09.1991, leg. D. Yanega (KNHM); Motozintla $\left(92^{\circ} 14^{\prime} \mathrm{W}, 15^{\circ} 21^{\prime} \mathrm{N}\right)$, $7.4 \mathrm{~km}$ SSW, cloud forest litter, 4 specimens, 17.09.1992, leg. R. Anderson (KNHM); Jalapa, $2.3 \mathrm{~km} \mathrm{~S}$, deep litter in rock cracks, 1320 m elevation, 1 specimen, 18.07.1992, leg. J.S. Ashe (KNHM); Bazóm, Chiapas, Mpio., Huixtán, mixed magnolia/oak forest litter, 1 specimen, 09.07.2003, leg. R. Anderson (KNHM); Guatemala: Quezaltenango, $14.4 \mathrm{~km}$ SW Zunil, $1340 \mathrm{~m}$ elevation, 1 specimen, 18.06.1993, leg. J.S. Ashe (KNHM); Panzos, 2 specimens without further data, leg. G.C. Champion (AMNH).

Diagnosis: O. parcus is similarly sized as O. sexpunctatus and O. majusculus. In O. sexpunctatus the pronotum is more convergent from anterior angles to posterior angles than in O.parcus. Furthermore, the setiferous punctation of the pronotum is denser than in O. sexpunctatus, and the protibia is strongly digitate at outer edge. Compared to the similar O. rougemonti, $O$. parcus is larger and the pronotal punctation is denser and the punctures smaller.

Description: Length: $7.2 \mathrm{~mm}$. Colouration: Black; legs and antennae reddish.

Head: $1.00 \mathrm{~mm}$ long, $1.50 \mathrm{~mm}$ wide; eyes not prominent; angles of clypeus produced to short granules; anterior edge slightly emarginate; setiferous and granulate punctures irregularly dense; moderately wide midline and area at base of antennae impunctate; on average, interstices between punctures as wide as or slightly wider than diameter of punctures; supraocular punctures coriaceous; dense netlike microsculpture distinct; surface slightly shiny.

Antennae with first antennomere slightly shorter than four following antennomeres; second antennomere oblong; longer than wide and nearly as long as conical third; following three antennomeres increasing in width, but decreasing in length; sixth antennomere quadrate; following four antennomeres slightly wider than sixth antennomere; approximately quadrate; last antennomere smaller than penultimate antennomere.

Pronotum: $1.30 \mathrm{~mm}$ long, $1.40 \mathrm{~mm}$ wide; widest at anterior angles; anterior angles slightly produced to short teeth; evenly convergent to posterior angles; more distinctly convergent in posterior third; lateral margin fine; setiferous punctures distinctly larger than on head and not granulate; along impunctate midline in irregular rows; adjacent to midline punctures partly coriaceous; laterally sparser; on average, interstices between punc- tures shorter than or as wide as diameter of punctures; fine microsculpture netlike; sparse micro-punctation present. Elytra: $1.50 \mathrm{~mm}$ long, $1.50 \mathrm{~mm}$ wide; coriaceous groundsculpture; punctures deep, in irregular rows.

Abdomen with dense setiferous punctation and narrow impunctate midline; weak isodiametric microsculpture; surface shiny.

Protibia: $0.79 \mathrm{~mm}$ long, $0.35 \mathrm{~mm}$ wide; 10 spines on outer edge; apical 4 spines on short digits; WLR: 1.40; in posterior aspect; comb at inner emargination visible throughout its total length; posterior face with moderately dense setation.

Aedeagus with slender apical lobe widely curved to acute apex; at inner edge of apical lobe slightly sinuate at base.

\section{Osoriellus parumpunctatus n. sp. (Figs 64A-C, 97D)}

Type material: Holotype, male: Paraguay: Villarica, Jan. 1938, leg. F. Schade (UIC).

Diagnosis: The species can be differentiated from the other similarly large species by the sparsely punctate pronotum. Concerning the size and polished pronotum, it resembles O.minor, O. tuxtlae, and O. bicolor. However, O. minor and O. tuxtlae are larger between 4.6 and $4.8 \mathrm{~mm}$, whereas $O$. bicolor is smaller with $3.5 \mathrm{~mm}$. The pronotal punctation of $O$. tuxtlae is much denser than the pronotal punctations of $O$. minor and $O$. bicolor. The inner row of punctures adjacent to the impunctate midline has both 8 and 12 punctures in O. bicolor and O. minor, respectively, whereas in O. parumpunctatus it has only 5 to 6 punctures.

Description: Length: $4.1-4.2 \mathrm{~mm}$. Colouration: Reddish brown, pronotum and elytra lighter reddish; legs and antennae yellow.

Head: $0.52 \mathrm{~mm}$ long, $0.76 \mathrm{~mm}$ wide; eyes not prominent; nearly as long as temples; sides of fore-head slightly concave; front margin of clypeus even without lateral granules; setiferous punctation irregularly dense; fore-head and clypeus sparsely punctate; on average, interstices between punctures at least as wide as diameter of punctures; vertex more densely punctate except wide impunctate midline; interstices between punctures less wide than half of diameter of punctures; on narrow supraocular area nearly coriaceously punctate; without microsculpture except on lateral vertex with weak remains of netlike microsculpture; surface on most parts polished and shiny.

Antennae shortly longer than head; second antennomere nearly globular; third conical antennomere shorter than second; fourth antennomere as wide as third, but quadrate; following antennomeres increasing in width; fifth and sixth antennomeres wider than long and slightly wider than fourth; antennomeres 7 to 10 thicker than preceding antennomeres and quadrate. 
Pronotum: $0.71 \mathrm{~mm}$ long, $0.80 \mathrm{~mm}$ wide; widest at anterior angles; slightly and evenly convergent to posterior angles; lateral margin very fine; in dorsal aspect, visible throughout its total length; setiferous punctation sparse; punctures large and in irregular rows; inner row adjacent to impunctate midline with 5 to 6 punctures; interstices between punctures at least as wide as diameter of punctures; between large punctures with sparse micropunctation; surface without microsculpture; polished and shiny.

Elytra: $0.87 \mathrm{~mm}$ long, $0.83 \mathrm{~mm}$ wide; with weak coriaceous ground-sculpture; setiferous punctation distinctly visible; punctures in irregular rows.

Abdomen with dense setiferous punctation and narrow impunctate midline; tergites VII and VIII less densely punctate than anterior tergites; without microsculpture; surface polished and shiny.

Protibia: $0.48 \mathrm{~mm}$ long, $0.16 \mathrm{~mm}$ wide; 8 spines on outer edge; WLR: 2.30; in posterior aspect, comb of inner emargination visible in its total length; posterior face with moderately dense setation.

Aedeagus with narrow apical lobe ending in obtuse apex; inner edge of apical lobe with row of few sensillae.

Etymology: The specific name is a combination of the Latin word parum meaning few and punctatus meaning punctate and refers to the sparsely punctate pronotum.

\section{Osoriellus punctatellus $\mathrm{n}$. sp.}

(Figs 47A-C, 94E)

Type material: Holotype, male: Ecuador: Cotopaxi, Tinalandia, Santo Domingo de los Colorados, $700 \mathrm{~m}$ elevation, collected at light, 18.5.1993, leg. J.J. Morrone $(\mathrm{AMNH})$.

Paratypes: Ecuador: with same data as for holotype, abdomen lost (UIC); Pichincha, Tinalandia $\left(79^{\circ} 03^{\prime} 39 \mathrm{~W}\right.$, $\left.0^{\circ} 16^{\prime} 53 \mathrm{~S}\right), 800 \mathrm{~m}$ elevation, 2 females, 2.11.1983, leg. L. Huggert (SMNH); Pichincha, Maquipucuna, $50 \mathrm{~km}$ NW Quito, banana, Berlese, female, 23.12.1991, leg. C.E. Carlton (KNHM); Maquipucuna, montane evergreen forest litter, male \& female, 27.10.1999, leg. R. Anderson (KNHM); Peru: Madre de Dios, 15 km NE Puerto Cusco Amazonica, flight intercept trap, female, 17.06.1989, leg. R. Leschen (KNHM); Panama: Colon, Parque Nat. Soberania Pipeline Road $\left(79^{\circ} 45^{\prime} \mathrm{W}, 9^{\circ} 07^{\prime} \mathrm{N}\right)$, flight intercept trap, female, 27.05.1995, leg. J. Jolly \& C. Chaboo (KNHM); Colon, Parque Nat. Soberania, Pipeline Road $\left(79^{\circ} 45^{\prime} \mathrm{W}, 9^{\circ} 07^{\prime} \mathrm{N}\right)$, from leaf litter, female, 29.05.1995, leg. J. Jolly \& C. Chaboo (UIC); Colon, Parque Nat. Soberania, Pipeline Road km $5.3\left(79^{\circ} 45^{\prime} \mathrm{W}\right.$, $\left.9^{\circ} 07^{\prime} \mathrm{N}\right), 40 \mathrm{~m}$ elevation, collected by flight intercept trap, male, 31.5.-2.6.1995, leg. J. Ashe \& R. Brooks (KNHM).

Diagnosis: The species strongly resembles $O$. indescriptus in size and both the shape and punctation of the prono- tum. The colouration is darker than in O. indescriptus and the aedeagus has a more acute apex, whereas the adeagal apex of $O$. indescriptus is stout. The shape of the aedeagus is similar to that of $O$. exiguus, but the pronotal punctation of $O$. exiguus is distinctly sparser.

Description: Length: 2.8. Colouration: Black; elytra dark brown with posterior margin black; anterior margin of clypeus yellow; legs and antennae yellow.

Head: $0.45 \mathrm{~mm}$ long, $0.50 \mathrm{~mm}$ wide; with eyes not prominent; as long as temples; shape of fore-head trapezoidal; setiferous punctation dense and deep; on supraocular vertex still coarser; on lateral clypeus sparser and finer; wide midline impunctate; midline on clypeus wider than on posterior vertex; without microsculpture; surface of midline and clypeus polished and shiny.

Antennae with second antennomere oval and slightly thicker than following 4 antennomeres; third antennomere conical; fourth antennomere quadrate; antennomeres 5 and 6 slightly wider than long, but not wider than preceding antennomeres; antennomeres 7 to 11 much wider than preceding antennomeres and wider than long; tenth antennomere nearly twice as wide as long.

Pronotum: $0.50 \mathrm{~mm}$ long, $0.50 \mathrm{~mm}$ wide; widest at anterior angles; evenly convergent to posterior angles in smooth curve; in posterior third slightly more strongly convergent; lateral margin fine; in dorsal aspect, not visible in anterior half; setiferous punctation coarse, deep and dense; on average, interstices between punctures one-fourth as wide as diameter of punctures; with narrow impunctate midline; without microsculpture, but with sparse micro-punctation; surface polished and shiny.

Elytra: $0.65 \mathrm{~mm}$ long, $0.55 \mathrm{~mm}$ wide; with deep and coarse setiferous punctation; with remains of microsculpture, but mainly polished and shiny.

Abdomen deeply and densely punctate; narrow midline without setiferous punctures and shiny.

Protibia: $0.30 \mathrm{~mm}$ long, $0.10 \mathrm{~mm}$ wide; nearly semicircular; 8 spine on outer edge; WLR: 2.50; in posterior aspect, comb of inner emargination totally visible; posterior face densely covered by setae.

Aedeagus with long basal lobe; acute apical lobe nearly in rectangular angle to basal lobe.

Etymology: The specific name refers to the densely and coarsely punctate pronotum.

\section{Osoriellus rougemonti $\mathrm{n} . \mathrm{sp}$. (Figs 84B-C, 100C)}

Type material: Holotype, male: Ecuador: Napo Prov., Sacha Lodge $\left(76^{\circ} 27.32^{\prime \prime} \mathrm{W}, 0^{\circ} 28.15^{\prime} \mathrm{S}\right), 250 \mathrm{~m}$ elevation, 26.-28.10.2004, leg. G. de Rougemont (UIC).

Paratypes: Colombia: without further data, as O. columbicus in litteris name given by Bernhauer, female 
(BMNH); Magdalena, N. Sierra Nevada de Marta, Rio Buritaca, male, 19.11.1974, leg. M. Cooper (BMNH).

Diagnosis: The species resembles O. schwarzi, O. opacus, O. opacinotus and O. neotropicus in size. It can be easily differentiated from O. opacus by the absence of the isodiametric microsculpture of the elytra and from O. schwarzi by the longitudinal microsculpture of the pronotum. Both O.opacinotus and O. neotropicus differ by the protibial digits, the shinier surface and the different shape of the pronotum. The apical part of the aedeagus in O. rougemonti is more curved and thicker than in O. schwarzi.

Description: Length: $5.8 \mathrm{~mm}$. Colouration: Black, elytra dark red, legs light brown.

Head: $0.80 \mathrm{~mm}$ long, $1.22 \mathrm{~mm}$ wide; eyes not prominent; sides of fore-head concavely convergent to anterior margin of clypeus; anterior margin of clypeus even without lateral granules; setiferous punctation moderately dense; large area at base of antennae impunctate; punctation on supraocular area much denser than on vertex; partly coriaceous; isodiametric microsculpture deep and dense; surface hardly shiny.

Antennae destroyed.

Pronotum: $1.24 \mathrm{~mm}$ long, $1.37 \mathrm{~mm}$ wide; widest at anterior angles; anterior angles shortly produced to acute teeth; sides convergent in smooth curve to posterior smoothly rounded angles; in anterior half less convergent than in posterior half; anterior edge 1.7 times as wide as posterior edge; lateral margin moderately thick; in dorsal aspect, not visible close to anterior angles; setiferous punctation moderately dense; punctures larger than on head; on average, interstices between punctures as wide as diameter of punctures; within row adjacent to impunctate midline, interstices between punctures denser; approximately 10 punctures in row; between setiferous punctures with sparse micro-punctation; microsculpture distinct; partly netlike, partly longitudinal; surface more shiny than on head.

Elytra: $1.30 \mathrm{~mm}$ long, $1.35 \mathrm{~mm}$ wide; with weak coriaceous ground-sculpture; irregular rows of setiferous punctures distinctly visible.

Abdomen with dense setiferous punctation and with narrow impunctate midline on tergites; netlike microsculpture moderately weak; surface shiny.

Protibia: $1.09 \mathrm{~mm}$ long, $0.41 \mathrm{~mm}$ wide; 9 spines on outer edge; WLR: 6.0; in posterior aspect, comb of distinct inner emargination covered in middle; posterior face densely covered by short setae.

Aedaegus with apical lobe slightly shorter than basal lobe; thick apical lobe sharply curved and ending in obtuse apex.

Etymology: The species is named to honour its collector Dr. G. de Rougemont.
Osoriellus rubripennis n. sp.

(Figs 89A-C, 100E)

Type material: Holotype, male: Peru: Tambopata Prov., Madre de Dios Depto., $15 \mathrm{~km}$ NE Puerto Maldonado, Reserva Cuzco Amazónico (6903'W, 12³3S), $200 \mathrm{~m}$ elevation, Plot \#Z2E17, collected by flight intercept trap, 20.6.1989, leg. J.S. Ashe, R.A. Leschen \#175 (KNHM).

Paratypes: Peru: 2 females with same date as holotype (KNHM, UIC).

Diagnosis: O. rubripennis is characterised by the deep isodiametric microsculpture of the pronotum and the matt pronotal surface. The trapezoidal shape of the pronotum is also found in several other species of the group, e.g. O. verhaagi. O. verhaaghi is larger and the isodiametric pronotal microsculpture is weaker and the surface shinier. A similar pronotal microsculpture is found in O. opacinotus of the remaining-species-group with long protibial digits that are absent in O. rubripennis. Additionally, O. opacinotus is larger and the pronotal lateral margin is different.

Description: Length: $5.1 \mathrm{~mm}$ long. Colouration: Dark brown, posterior edge of pronotum, elytra and abdomen dark reddish, legs and antennae red.

Head: $0.65 \mathrm{~mm}$ long, $1.05 \mathrm{~mm}$ wide; eyes slightly prominent and slightly longer than temples; fore-head deeply emarginate; sides of clypeus parallel; anterior edge of clypeus even with shortly produced acute angles; setiferous punctation irregularly dense and moderately deep; on clypeus sparser than on lateral vertex; on supraocular and postocular area, punctation very dense and granulate; on clypeus and posterior vertex with impunctate midline; wide area at base of antennae impunctate; yellow setae as long as diameter of punctures and interstice between two punctures combined; isodiametric microsculpture deep; surface matt.

Antennae slightly longer than head; second antennomere oval and slightly longer than conical third; antennomeres 4 to 6 slightly increasing in width and approximately quadrate; antennomeres 7 to 11 distinctly wider than preceding antennomeres, but also quadrate.

Pronotum: $1.12 \mathrm{~mm}$ long, $1.21 \mathrm{~mm}$ wide; widest close to anterior angles; anterior angles obtuse; sides evenly convergent to posterior angles; shortly in front of posterior angles slightly sinuate; posterior angles obtusely rounded; lateral margin fine; slightly widened close to posterior angles; in dorsal aspect, not visible close to anterior angles; setiferous punctation deeper than on head; irregularly dense; on average, interstices between punctures twice as wide as diameter of punctures; yellow setae as long as on head or slightly shorter; isodiametric microsculpture deeper than on head; surface matt.

Elytra: $1.19 \mathrm{~mm}$ long, $1.19 \mathrm{~mm}$ wide; widest in posterior third, but nearly parallel; setiferous punctation dense and moderately deep; denser than on pronotum and in 
irregular rows; with deep isodiametric microsculpture; surface still matter than on pronotum.

Abdomen with dense setiferous punctation; netlike microsculpture much weaker than on fore-body; punctures mostly granulate; last tergites without striae.

Protibia: $0.59 \mathrm{~mm}$ long, $0.19 \mathrm{~mm}$ wide; thick; nearly semicircular; 8 spines inserted directly on outer edge; WLR: 3.0; in posterior aspect, comb of inner emargination visible throughout its total length; posterior face densely covered by long yellow setae.

Aedeagus with long apical lobe ending in widely rounded obtuse apex; apical lobe longer than basal lobe; at inner edge of apical lobe, one sensilla close to apex and seven sensillae closer to base.

Etymology: The specific name is a combination of the Latin words rubra meaning red and penna meaning elytra and refers to the reddish elytra.

\section{Osoriellus rugipennis (BERNHAUER, 1910) new combination \\ (Figs 70A-C, 98C)}

Osorius rugipennis BeRnHAUER, 1910: 361

Type material examined: Mexico: Veracruz, Orizaba $\left(97^{\circ} 06 \mathrm{~W}, 18^{\circ} 50^{\prime} \mathrm{E}\right), 2$ females, leg. H.S. \& F.D.G. (holotype and paratype in FMNH examined).

Further material examined: Mexico: Real de Arriba, Temescaltepec, 3 specimens, 19.06.1933, H.E. Hinton (AMNH); Real de Arriba, $6300 \mathrm{ft} .4$ specimens, 1.07.1932, H.E. Hinton (AMNH); Union Juarez, NE slope Vulc. Tacana, Barranca Providencia, leaf litter stream, montane trop. forest, 1540 m elevation, 1 specimen, 25.12.1975, leg. H. Frania (KNHM); Guatemala: Quetzaltenango, $12.9 \mathrm{~km}$ SW Zunil, berlese forest litter, 5 males, 12 females, 18.6.1993, leg. R. Anderson, \& J.S. Ashe (KNHM, UICI; Nicaragua: Matagalpa, Selva Negra $\left(85^{\circ} 54.53^{\prime} \mathrm{W}, 12^{\circ} 59.99 \mathrm{~N}\right)$, under bark, 1 specimen, 19.05.2002, leg. R. Brooks, Z. Falin \& S. Chatzimanolis (KNHM); Granada, Res. Nat. Volcan Mombacho, cloud forest litter $\left(85^{\circ} 58.8^{\prime} \mathrm{W}, 11^{\circ} 50.0^{\prime} \mathrm{N}\right), 150 \mathrm{~m}$ elevation, 3 specimens, 05.06.2002, leg. R. Anderson (SEM); Costa Rica: Puntarenas, Rincon de Osa $\left(83^{\circ} 31.17^{\prime} \mathrm{W}\right.$, $\left.8^{\circ} 41.14^{\prime} \mathrm{N}\right), 50 \mathrm{~m}$ elevation, flight intercept trap, 1 specimen, 23.-26.6.2001, S. \& J. Peck (KNHM); Puntarenas, Rincon de Osa, Rd. Bahia Drake-Rincon, devastated forest, plantations, $0-400 \mathrm{~m}$ elevation $\left(83^{\circ} 29^{\prime} \mathrm{W}, 8^{\circ} 41^{\prime} \mathrm{N}\right)$, car net, male, 9.12.2012, leg. M. Schülke \& Grünberg (UIC); Panama: Chiriqui Prov., Los Planes, $5 \mathrm{~km}$ N Finca la Suiza, $4502 \mathrm{ft}$. elevation, 1 specimen, 30.05.1995, leg. B. Ratcliffe (KNHM); Colon, Parque Nac. Soberania, Pipeline Rd. km 6.1, flight intercept trap, 2 specimens, 7.-21.6.1995, leg. J. Ashe \& R. Brooks (KNHM); Colombia: Valle del Cauca, Sevilla $\left(75^{\circ} 56^{\prime} \mathrm{W}\right.$, $\left.4^{\circ} 16^{\prime} \mathrm{N}\right), 3$ partly destroyed specimens, 1.7.1921, leg.
G. Salt (BMNH); Ecuador: Pichincha, Rio Palenque Science Center $\left(79^{\circ} 21.0^{\prime} \mathrm{W}, 0^{\circ} 36.0^{\prime} \mathrm{S}\right)$, flight intercept trap, 3 specimens, 25.4.-6.6.1996, leg. P. Hibbs (KNHM, UIC); Mindo, $10.6 \mathrm{~km}$ W Mindo Road $\left(78^{\circ} 45.14^{\prime} \mathrm{W}\right.$, $\left.0^{\circ} 4.23^{\prime} \mathrm{S}\right), \quad 1460 \mathrm{~m}$ elevation, flight intercept trap, 1 specimen, 26.-29.03.1999, leg. R. Brooks \& D. Brzoska (SEM); Peru: Junin, Satipo, San Beni, 1 specimen, 20.01.1984, leg. L. Huggert (MZLU).

Diagnosis: The species highly resembles $O$. franckei in the size, shape and punctation of the pronotum. The pronotal punctation is slightly denser than in O. franckei and the pronotal microsculpture is deeper and denser. Thus, in contrast to $O$. franckei, the pronotal surface of $O$. rugipennis is matt.

Description: Length: $4.5 \mathrm{~mm}$, Colouration: Dark brown, elytra slightly lighter brown with suture and anterior edge reddish; front legs red, middle and hind legs as well as antennae yellow.

Head: $0.5 \mathrm{~mm}$ long, $0.75 \mathrm{~mm}$ wide; anterior edge even; without any granules; deeply and densely punctate; interstices between setiferous punctures shorter than diameter of punctures; with impunctate midline; at base of antennae impunctate and surface polished; on vertex microsculpture deep and circular; surface matt.

Antennae with third antennomere slightly shorter than second; fourth antennomere longer than wide and fifth to sixth antennomeres quadrate; following antennomeres wider than long and distinctly thicker than preceding antennomeres.

Pronotum: $0.80 \mathrm{~mm}$ long, $0.80 \mathrm{~mm}$ wide; sides widest at anterior angles; evenly convergent to posterior angles; posterior angles rounded; lateral and posterior margin narrow and visible throughout its total length; with large and dense setiferous punctures; impunctate midline; on each side of midline with row of 8 punctures; lateral punctures in irregular rows; on average, interstices between punctures shorter than diameter of punctures; setae long and yellow; netlike microsculpture distinct, but less deep than on head; surface moderately shiny.

Elytra: $0.95 \mathrm{~mm}$ long, $0.85 \mathrm{~mm}$ wide; coarsely and densely punctate; partly with coriaceous setiferous punctures; irregular rows of 8 to 12 punctures; with very weak microsculpture; surface nearly polished.

Abdomen densely and deeply punctate except moderately wide impunctate midline; microsculpture weak and surface shiny.

Protibia: $0.52 \mathrm{~mm}$ long, $0.16 \mathrm{~mm}$ wide; 8 spines on outer edge; apical 3 spines inserted on short digits; WLR: 2.2; in posterior aspect, comb of inner emargination totally visible; posterior face with moderately dense setation. Aedeagus angulate in nearly rectangular angle; apical lobe long; apex obtuse; 7 sensillae at inner edge of apical lobe. 


\section{Osoriellus salvini (SHARP, 1887) new combination} (Figs 61A-C, 96B)

Osorius salvini SHARP, 1887: 682

Type material examined: Guatemala: Guatemala $\left(90^{\circ} 31^{\prime} \mathrm{W}, 14^{\circ} 36^{\prime} \mathrm{N}\right)$, near the city, female, leg. Salvin (syntype in BMNH); San Jerónimo $\left(90^{\circ} 14^{\prime} \mathrm{W}, 15^{\circ} 03^{\prime} \mathrm{N}\right)$, female, leg. Champion (syntype in BMNH).

Further material examined: Mexico: Valle de Arriba $\left(93^{\circ} 52^{\prime} \mathrm{W}, 16^{\circ} 13^{\prime} \mathrm{N}\right), 2630 \mathrm{ft} ., 1$ male, 3 females, 1.7.1932, leg. H.E. Hinton (AMNH); Mexico without further data, 1 male, 3 females, coll Sharp (BMNH); 1 female, without more data (SDEI); Guatemala: Panzos $\left(89^{\circ} 37^{\prime} \mathrm{W}\right.$, $\left.15^{\circ} 24^{\prime} \mathrm{N}\right)$, female, leg. Champion (AMNH); Costa Rica: Guanacaste, Liberia, Rd. to Hacienda Guachipelin, farmland and dry forest (135-530 m elevation $\left(85^{\circ} 22^{\prime} \mathrm{W}\right.$, $\left.10^{\circ} 39^{\prime} \mathrm{N}\right)$, car net, 1 male, 4 females, 5.12.2012, leg. M. Schülke \& Grünberg (MSC, UIC); Puntarenas, Rincon de Osa, S Rincon de la Vieja, Rd. Hacienda Guachipilin-Santa Maria, dry forest, pasture, 520-700 m elevation $\left(85^{\circ} 20^{\prime} \mathrm{W}, 10^{\circ} 42^{\prime} \mathrm{N}\right)$, car net, female, 4.12.2012, leg. M. Schülke \& Grünberg (MSC); Panama: Paraiso (79³7.30'W, $\left.9^{\circ} 01.53^{\prime} \mathrm{N}\right)$, female, 22.1.1911, leg. E.A. Schwarz (AMNH); Trinidad: Sangre Grande $\left(61^{\circ} 08^{\prime} \mathrm{W}, 10^{\circ} 35^{\prime} \mathrm{N}\right)$, male, 5.1.1944, coll. C.E. Tottenham (BMNH); Venezuela: Aragua, Rancho Grande, $5 \mathrm{~km} \mathrm{~S}$ Biol. Stat. $\left(67^{\circ} 41^{\prime} \mathrm{W}, 10^{\circ} 22^{\prime} \mathrm{N}\right), 900 \mathrm{~m}$ elevation, 2 males, 26.6.-9.7.1994, leg. T. Philips (KNHM); Paraguay: Villarica $\left(55^{\circ} 32.32^{\prime} \mathrm{W}, 2^{\circ} 51.32^{\prime} \mathrm{S}\right), 5$ males, 18 females, Jan. 1938, leg. F. Schade (Blackwelder collection) (AMNH); Argentina: Tucuman, 1 female, Nov. 1905, leg. Vezényi (NHMH).

Diagnosis: The species is similar to O. bicolor and O. micros concerning the large punctures of the pronotum. It can be differentiated from O. micros and O. bicolor by its larger size and the coriaceous punctation of the head.

Description: Length: 3.8 - $3.9 \mathrm{~mm}$. Colouration: Head and pronotum brown; pronotum lighter reddish; elytra still lighter red to yellow with darker spot in posterior half; legs and antennae yellow.

Head: $0.70 \mathrm{~mm}$ long, $0.80 \mathrm{~mm}$ wide; eyes moderately long; as long as temples, but not prominent; sides of forehead shortly narrowed to anterior angles; anterior edge of clypeus even; without teeth; setiferous punctation on large supraocular area dense; deep and striate; partly coriaceous; on clypeus with sparser and finer punctation; yellow setae pointing to middle; wide midline on vertex and clypeus impunctate; without microsculpture; surface polished; on midline and clypeus shiny; adjacent to eyes matt due to dense coriaceous punctation.

Antennae with first antennomere slightly shorter than three following antennomeres; second antennomere oval and slightly longer than conical third antennomere; antennomeres 4 to 6 more or less quadrate and not wider than preceding antennomeres; following antennomeres distinctly thicker, but also quadrate.

Pronotum: $0.80 \mathrm{~mm}$ long, $0.85 \mathrm{~mm}$ wide; widest at anterior angles; evenly narrowed to posterior angles; in posterior half slightly more strongly convergent than in anterior half; lateral margin fine; in dorsal aspect, visible throughout its total length except short part behind anterior angles; setiferous punctures large and deep; along midline in irregular rows; first row adjacent to midline with 9 punctures; most parts of disc without microsculpture; surface polished; only few parts with remains of weak microsculpture; on polished parts with sparse micro-punctation; surface more or less shiny.

Elytra: $0.90 \mathrm{~mm}$ long, $0.80 \mathrm{~mm}$ wide; with weak coriaceous ground sculpture; setiferous punctation distinct, but finer and sparser than on pronotum; setae shorter than on head and pronotum.

Abdomen distinctly punctate; yellow setae pointing to middle; without microsculpture; surface moderately shiny.

Protibia: $0.50 \mathrm{~mm}$ long, $0.15 \mathrm{~mm}$ wide; 8 stout spines on outer edge; WLR: 3.5; in posterior aspect, inner edge slightly emarginate and comb partly covered; posterior face covered with thick setae.

Aedeagus with short basal and apical lobe; equally long; apical lobe slightly curved to moderately acute apex.

\section{Osoriellus seriatus $\mathrm{n}$. sp. \\ (Figs 90A-C, 100E)}

Type material: Holotype, male: Peru: Tambopata Prov. Madre de Dios Depto., $15 \mathrm{~km}$ NE Puerto Maldonado, Reserva Cuzco Amazónico (6903'W, 12³3'S), $200 \mathrm{~m}$ elevation, collected by flight intercept trap by Plot \#Z2E17, 20.6.1989, leg. J.S. Ashe \& R.A. Leschen, (KNHM).

Paratypes: Peru: male with same data as holotype, but 17.7.1989 by flight intercept trap at swamp trail (UIC).

Diagnosis: Among the similarly sized species of the O.-s. str.-group with non-digitate protibia, O. seriatus resembles $O$. debilis in the size and punctation of the head and pronotum. In contrast to $O$. debilis, the lateral pronotal margin is slightly wider at the posterior angles, whereas in O. debilis the width is equal throughout the total length. Furthermore, the pronotal sides are more curved than in O. debilis. The aedeagus in O. seriatus is angulate, but evenly curved in O. debilis.

Description: Length: 5.4 long. Colouration: Black; legs and antennae reddish brown.

Head: $0.74 \mathrm{~mm}$ long, $1.13 \mathrm{~mm}$ wide; eyes slightly prominent; as long as temples; fore-head convergent to anterior angles in deep sinuate curve; anterior edge slightly emarginate; setiferous punctation moderately deep and dense; narrow midline, area at base of antennae, and transverse oval area close to neck impunctate; on clypeus, interstices between punctures wider than diameter of punctures; 
on vertex, interstices between punctures shorter than diameter of punctures; small supraocular area with dense coriaceous and partly granulate punctation; isodiametric microsculpture dense and moderately deep; surface slightly shiny.

Antennae slightly shorter than head and half of pronotum combined; second antennomere oval and as long as conical third; following three antennomeres slightly increasing in width; antennomeres 4 and 5 approximately quadrate; sixth antennomere slightly wider than long; following antennomeres distinctly wider than preceding antennomeres, but approximately quadrate.

Pronotum: $1.16 \mathrm{~mm}$ long, $1.31 \mathrm{~mm}$ wide; widest shortly behind anterior angles; convergent to posterior angles in smooth curve; posterior angles obtuse and shortly rounded; lateral margin fine; finer near anterior angles than at posterior angles; shortly and slightly widened near posterior angles; setiferous punctation deep and moderately dense; adjacent to wide impunctate midline in dense row; posteriad sparser; on average, interstices between punctures wider than diameter of punctures; between normal deep punctures with fine and sparse micro-punctation; isodiametric microsculpture dense and moderately deep; surface slightly shiny.

Elytra: $1.42 \mathrm{~mm}$ long, $1.27 \mathrm{~mm}$ wide; shoulders shortly rounded in nearly rectangular angle; sides nearly parallel; setiferous punctation finer than on pronotum and in irregular rows; coriaceous ground-sculpture deep; surface slightly shiny.

Abdomen with dense setiferous punctation; netlike microsculpture weak; surface slightly shiny.

Protibia: $0.65 \mathrm{~mm}$ long; $0.22 \mathrm{~mm}$ wide; 8 spines at outer edge; apical spines inserted on short broad teeth; WLR: 1.77; in posterior aspect, comb of inner emargination covered in middle; posterior face densely covered by long yellow setae.

Aedaegus acutely angulate; apical lobe and basal lobe thick and equally long; apical lobe evenly narrowed to obtuse apex; inner edge of apical lobe with 4 sensillae.

Etymology: The specific name seriatus derived from the same Latin word meaning in rows and refers to the punctation of pronotum and elytra.

Osoriellus schwarzi (NotMAN, 1925) new combination (Figs 81A-C, 100A)

Osorius schwarzi Notman, 1925: 11

Osorius schwarzi BLACKWELDER, 1943: 191

Type material examined: Cuba: Cayamas, 1 male, 20.5.??, leg. E.A. Schwarz (holotype in NHMW).

Further material examined: Mexico: Chiapas, Ruinas de Palenque $\left(91^{\circ} 58^{\prime} \mathrm{W}, 17^{\circ} 29^{\prime} \mathrm{N}\right), 3$ males, 1 female, 25.7.1973, 28.9.1974, leg. J. Reddell (AMNH); Chiapas, Volcan Tacaná, sumidero San Antonio, leaf litter beside Rio
Mala, 1760 m elevation, male, 20.12.1976, leg. H. Frania (AMNH); Union Juarez, NW slope Vulc. Tacana, leaf litter trop. rain forest, Rio de Finca Muxbal (GUAT), male, 21.12.1976, leg. H. Frania (AMNH); Guatemala: 1 male, leg. Conradt, without more data (SDEI); Vera Paz, Panzos $\left(89^{\circ} 37^{\prime} \mathrm{W}, 15^{\circ} 24^{\prime} \mathrm{N}\right), 2$ males, leg. G.C. Champion (SDEI); Honduras: Santa Barbara, Mt. Santa Barbara, $11.5 \mathrm{~km} \mathrm{~S} \& 5.6 \mathrm{~km}$ W Pena Blanca $\left(14^{\circ} 57^{\prime} \mathrm{N}, 88^{\circ} 05^{\prime} \mathrm{W}\right)$, $1500 \mathrm{~m}$ elevation, 16 specimens, 20.6. \& 28.8.1994, leg. R. Anderson, collected from cloud forest litter (KNHM, UIC); El Paraiso, $6.9 \mathrm{~km}$ W. Yuscarán, Cerro Montserrat $\left(13^{\circ} 55^{\prime} \mathrm{N}, 86^{\circ} 24^{\prime} \mathrm{W}\right), 1870 \mathrm{~m}$ elevation, 70 specimens, 10.6., 7.7., 27.7.1994, leg. R. Anderson, berlesate from forest litter (KNHM, UIC); same location, flight intercept trap, 5 specimens, 7.-10. \& 11.-27.6.1994, leg. J. Ashe \& R. Brooks (KNHM); Zamorano $\left(87^{\circ} 05^{\prime} \mathrm{W}, 14^{\circ} 02^{\prime} \mathrm{N}\right)$, $12 \mathrm{~km} \mathrm{~W}$; Francisco Morazán, Cerro Uyuca, forest litter, $1870 \mathrm{~m}$ elevation, Berlese, 27 specimens, 6.6., 9.6., 11.6., 27.6., 30.6.1994, leg. R. Anderson (KNHM, UIC); La Paz, Cordill. Montecillos, $25 \mathrm{~km} \mathrm{NW}$, hardwood litter, 1 specimen, 21.08.1994, leg. R. Anderson (KNHM); Yoro Dept., P.N. Pico Pijol $\left(87^{\circ} 37.6^{\prime} \mathrm{W}, 15^{\circ} 09.4^{\prime} \mathrm{N}\right.$, upper montane forest litter, $1300 \mathrm{~m}$ elevation, 4 specimens, 11.05.2002, leg. R. Anderson (KNHM); Dept. F. Morazán, Guiamaca $\left(86^{\circ} 52^{\prime} \mathrm{W}, 14^{\circ} 21^{\prime} \mathrm{N}\right)$, Res. Biol. El Chile, upper montane forest litter, 12 specimens, 08.05.2002, leg. R. Anderson (KNHM, UIC); Nicaragua: Matagalpa, $6 \mathrm{~km} \mathrm{~N}$, Selva Negra $\left(85^{\circ} 54^{\prime} 06 \mathrm{~W}, 12^{\circ} 59^{\prime} 09 \mathrm{~N}\right)$, sub-ridgetop cloud forest litter, $1450 \mathrm{~m}$ elevation, 3 specimens, 21.05.2002, leg. R. Anderson (KNHM); Matagalpa, 6 km NW, Selva Negra, Fountain of Youth trail $\left(85^{\circ} 54.53^{\prime} \mathrm{W}, 12^{\circ} 59.99^{\prime} \mathrm{N}\right)$, flight intercept trap, 1 specimen, 22.05.2002, leg. R.W. Brooks (KNHM); Matagalpa, 6 km N, Selva Negra, ridgetop cloud forest litter, $1480 \mathrm{~m}$ elevation, 1 specimen, 20.05.2002, leg. R. Anderson (KNHM); Costa Rica: Guanacaste, Cacao Biol. Stn., leaf litter, 1100-1200 melevation 2 specimens, 04.05.1995, leg. R. Anderson (KNHM); Cerro Amigos, 1780 m elevation, 1 specimen, 9.5.1989, leg. J. Ashe, R. Brooks \& R. Leschen (KNHM); Puntarenas, $35 \mathrm{~km}$ NE San Vito, nr. Las Alturas, trail to Cerro Enchandi, litter near stream, 45 specimens, 19.03.1991, leg. L. Herman (AMNH, UIC); 1 specimen from same location, but under bark and 20.3.1991, leg. L. Herman (AMNH); Puntarenas, $11 \mathrm{~km} \mathrm{SW} \mathrm{Biol} \mathrm{Stn} \mathrm{Las}$ Cruzes $\left(83^{\circ} 01.50^{\prime} \mathrm{W}, 8^{\circ} 46.43^{\prime} \mathrm{N}\right)$, wet cloud forest litter, $1450 \mathrm{~m}$ elevation, 1 specimen, Berlese, 9.7.1999, leg. R. Anderson (KNHM); Puntarenas, Monteverde Campbell's Woods, $1570 \mathrm{~m}$ elevation, flight intercept trap, 1 specimen, 21.5.1989, leg. J.S. Ashe (KNHM); Puntare-

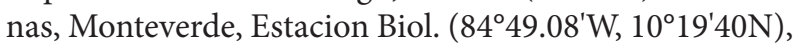
montane for. litter, $1540 \mathrm{~m}$ elevation, 1 specimen, 12.06.2001, leg. R. Anderson (KNHM); Monteverde, Campbell's Bull Pen, flight interc., 1 specimen, 29.05.1993, leg. S. Lingafelter (KNHM); Monteverde, 1400-1550 m elevation, 2 specimens, 26.05.1989, leg. J.S. Ashe, R. Brooks \& R. Leschen (KNHM); same location, 1570 m elevation pitfall traps, 15.5.1989, leg. J. Ashe, R. Brooks \& R. Leschen (KNHM, UIC); same location, flight inter- 
cept trap, $1520 \mathrm{~m}$ elevation, 17 specimens, 21.5.1989, leg. J. Ashe, R. Brooks \& R. Leschen (KNHM, UIC); same location, $1590 \mathrm{~m}$ elevation, Berlese, 1 specimen, 11.5.1989, leg. J. Ashe, R. Brooks \& R. Leschen (KNHM); same location, cloud forest, $1510 \mathrm{~m}$ elevation, flight interc., 1 specimen, 10.-17.06.2001, leg. J. Peck (KNHM); Las Cruzes, Biol. Stat., $1330 \mathrm{~m}$ elevation, flight interc., 1 specimen, 31.05.2004, leg. J.S. Ashe, Z. Falin \& I. Hinojosa (KNHM); San José, Pan American Hwy km 117, $19 \mathrm{~km} \mathrm{~N}$. S. Isidro $\left(83^{\circ} 42.20^{\prime} \mathrm{W}, 9^{\circ} 28.0^{\prime} \mathrm{W}\right), 1800 \mathrm{~m}$ elevation, flight interc., 1 specimen, 25.06.1997, leg. J. Peck (KNHM); Alajuela, Rio Penas Blancas, $1190 \mathrm{~m}$ elevation, flight interc., 1 specimen, 20.05.1989, leg. J. Ashe, R. Brooks \& R. Leschen (KNHM); Puntarenas, Peninsula de Osa, Rd. Banigones-Chacarita, pastures, plantages, devasted forest $\left(83^{\circ} 15^{\prime} \mathrm{W}, 8^{\circ} 36^{\prime} \mathrm{N}\right), 0-250 \mathrm{~m}$ elevation, car net, female, 11.12.2012, leg. M. Schülke \& Grünberg (MSC); Panama: Chiriqui, $12 \mathrm{~km}$ NE Santa Clara, Cerro Pando $\left(82^{\circ} 43.30^{\prime} \mathrm{W}, 8^{\circ} 54.44^{\prime} \mathrm{N}\right)$, oak forest litter, 1850 m elevation, 1 specimen, 17.6.1996, leg. R. Anderson (KNHM); Colon, Parque Nat. Soberania, Pipline Rd $\left(79^{\circ} 45^{\prime} \mathrm{N}, 9^{\circ} 07^{\prime} \mathrm{N}\right)$, flight intercept trap, 1 specimen, 27.5.1995, leg. J. Jolly (KNHM); Bocas del Toro, 7 km N Boquete, La Culebra trail $\left(82^{\circ} 48^{\prime} \mathrm{W}, 8^{\circ} 48^{\prime} \mathrm{N}\right), 1050 \mathrm{~m}$ elevation, 1 specimen, 15.07.1995, leg. A.R Gillogly (KNHM).

Diagnosis: O. schwarzi resembles O. neotropicus, O. opacus and O. opacinotus in size. It can be differentiated from O. opacus by the absence of the distinct microsculpture of the pronotum and from O. opacinotus by the less digitate protibia and the shorter second and third antennomeres that are as long as wide in $O$. schwarzi, but distinctly longer than wide in O. opacinotus. O. schwarzi highly resembles O. neotropicus, because the antennal structure, the shape and microsculpture of the pronotum and elytra are similar. But O. schwarzi clearly differs by the absence of the protibial digits. Additionally, the pronotal punctation is denser in O. schwarzi than in O. neotropicus and the apical lobe of the aedeagus is long and angulate, whereas it is nearly straight in O. neotropicus.

Description: Length: 5.6 - $6.3 \mathrm{~mm}$. Colouration: Black; legs and antennae yellow.

Head: $0.60 \mathrm{~mm}$ wide, $1.1 \mathrm{~mm}$ long; eyes small, slightly shorter than temples and not prominent; setiferous punctation moderately dense; impunctate midline widened to anterior and posterior edge; area at base of antennae impunctate; on vertex, interstices between punctures much shorter than diameter of punctures; on clypeus, interstices between punctures distinctly wider than diameter of punctures; several supraocular punctures with longer setae; isodiametric microsculpture deep; surface slightly shiny; surface of impunctate area at base of antennae without microsculpture polished and shiny.

Antennae with oval second and conical third antennomere; both antennomeres equally long; following 3 antennomeres shorter; approximately quadrate; antennomeres 7 to 11 distinctly wider than preceding antennomeres, but also approximately quadrate.

Pronotum: $1.10 \mathrm{~mm}$ long, $1.20 \mathrm{~mm}$ wide; widest at anterior angles, in anterior half slightly convergent; in posterior half more strongly convergent and slightly emarginate in front of posterior angles; setiferous punctation deeper than on head, but, on average, less dense; punctures in irregular rows; wide midline impunctate; microsculpture isodiametric; surface slightly shiny; in midline meshes of micosculpture more longitudinal.

Elytra: $1.25 \mathrm{~mm}$ long, $1.20 \mathrm{~mm}$ wide; with dense and deep punctation; punctures in irregular rows; hardly visible between deep coriaceous ground-sculpture; surface less shiny than on the pronotum.

Abdomen with dense setiferous punctation and small impunctate midline; surface without microsculpture, shiny.

Protibia: $0.73 \mathrm{~mm}$ long, $0.23 \mathrm{~mm}$ wide; 10 spines on outer edge; spines directly inserted on outer edge; WLR: 4.77; in posterior aspect, comb at inner emargination visible throughout its total length; on anterior face with curved row of setiferous punctures; posterior face covered by long yellow setae; setae nearly half as long as protibial width.

Aedeagus rectangularly angulate; apical lobe thick and long; apical lobe with obtuse apex and several sensillae at inner edge.

\section{Osoriellus surinamensis n. sp. \\ (Figs 55A-C, 96A)}

Type material: Holotype, male: Suriname: Brokopondo, Brownsberg Nature Preserve $\left(55^{\circ} 10.53^{\prime} \mathrm{W}, 4^{\circ} 56.55^{\prime} \mathrm{N}\right)$, ca. $440 \mathrm{~m}$ elevation, ex flight intercept trap, 22.-25. Jun. 1999, leg. Z.H. Falin, \#SUR1F99 (KNHM).

Diagnosis: According to the size and microsculpture of the pronotum, the species resembles O. micros and O. brevicornis. Compared to both species, the eyes are more prominent, the pronotal punctation is denser and the antennae are thicker. In particular, the antennomeres 2 to 6 are distinctly thicker than in O. micros and O. brevicornis.

Description: Length: $3.8 \mathrm{~mm}$. Colouration: Dark reddish; pronotum and abdomen slightly lighter reddish; legs and antennae yellow.

Head: $0.47 \mathrm{~mm}$ long, $0.72 \mathrm{~mm}$ wide; eyes prominent; slightly longer than temples; sides of fore-head convergent in concave curve to anterior angles; anterior edge of clypeus even with short granules at angles; setiferous punctation deep and moderately dense; on average, interstices between punctures slightly shorter than diameter of punctures; on supra- and postocular area few punctures with longer setae; netlike microsculpture dense and deep; surface matt. 
Antennae slightly longer than head; second antennomere globular and thicker than conical third; antennomeres 4 to 6 as wide as third antennomere, but shorter; wider than long; antennomeres 7 to 10 distinctly wider than preceding antennomeres; approximately 1.5 times wider than long.

Pronotum: $0.69 \mathrm{~mm}$ long, $0.75 \mathrm{~mm}$ wide; widest at anterior angles; evenly convergent to posterior angles except slight emargination in anterior third and in front of posterior angles; lateral margin fine; finer in anterior half than in posterior half; in dorsal aspect, from anterior emargination to anterior angles not visible; setiferous punctation large and denser than on head; punctures in irregular rows; on average, interstices between punctures half as wide as diameter of punctures; impunctate midline at posterior edge twice as wide as at anterior edge; netlike microsculpture weaker than on head; surface, thus, more shiny than on head.

Elytra: $0.88 \mathrm{~mm}$ long, $0.82 \mathrm{~mm}$ wide; with rounded shoulders; setiferous punctation dense and deep; in irregular rows; weak coriaceous ground-sculpture and irregular, distinct microsculpture; surface matt.

Abdomen as densely and deeply punctate as elytra; punctures with yellow setae; narrow midline impunctate and shiny; anterior segments on punctate area with microsculpture; surface matt; segements VII and VIII without microsculpture; surface polished and shiny.

Protibia: $0.46 \mathrm{~mm}$ long, $0.14 \mathrm{~mm}$ wide; 10 spine on outer edge; WLR: 6.0; in posterior aspect, comb at inner emargination shortly covered in middle; posterior face with dense setation; setae nearly half as long as protibial width. Aedeagus with slightly curved apical lobe; apical lobe approximately in line with basal lobe; 6 sensillae at inner edge.

Etymology: The specific name derived from the country, where the species was collected.

\section{Osoriellus trapezoides $\mathrm{n}$. sp.} (Figs 82A-C, 101A)

Type material: Holotype, male: Costa Rica: Puntarenas Prov., Altamira Biol. Sta. $\left(83^{\circ} 00.49^{\prime} \mathrm{W}, 09^{\circ} 01.76^{\prime} \mathrm{N}\right)$, 1510-1600 m elevation, collected by flight intercept trap CR1AFH04144, 4.-7.VI.2004, leg. J.S. Ashe, Z. Falin, I. Hinojosa (KNHM).

Paratype: Costa Rica: Alajuela, E.B. San Ramon, R.B. San Ramon, $27 \mathrm{~km} \mathrm{~N} \mathrm{\&} 8 \mathrm{~km}$ W San Ramon $\left(84^{\circ} 35.30^{\prime} \mathrm{W}\right.$, $\left.10^{\circ} 13.30^{\prime} \mathrm{N}\right)$, male, collected from wet montane forest litter CR1A99-109D, 29.6. - 6.7.1999, leg. R. Anderson (UIC).

Diagnosis: The species is similarly sized as O. debilis, but the shape of the head and pronotum is distinctly different. It can be easily identified by the conspicuous trapezoidal shape of the head.
Description: Length: $5.2 \mathrm{~mm}$. Colouration: Dark brown; elytra reddish brown; legs and antennae lighter brown. Head: $0.63 \mathrm{~mm}$ long, $1.06 \mathrm{~mm}$ wide; eyes slightly prominent and slightly longer than temples; sides of fore-head convergent to front angles in slight sinuate curve; close to anterior edge nearly parallel; in dorsal aspect, shape trapezoidal; clypeal angle produced to short granules; anterior edge even; setiferous punctation weak and sparse; near base of antennae impunctate and on supraocular area with denser punctation; on vertex, interstices between punctures wider than diameter of punctures; one supraocular seta and one neck seta longer than normal setation; isodiametric microsculpture extremely weak; surface shiny, nearly polished.

Antennae distinctly longer than head; with oblong second antennomere and conical third antennomere; each longer than wide; following three antennomeres not wider than preceding antennomeres, but approximately quadrate; antennomeres 7 to 11 thicker than preceding antennomeres and also quadrate.

Pronotum: $0.98 \mathrm{~mm}$ long, $1.08 \mathrm{~mm}$ wide; widest at anterior angles; anterior angles produced to short teeth; sides slightly convergent in anterior two-third; more strongly convergent in posterior third; lateral margin fine; close to anterior angles invisible in dorsal aspect; posterior angles obtuse; smoothly rounded; setiferous punctation deeper and denser than on head; with impunctate midline; 10 punctures in irregular row adjacent to midline; on average, interstices between punctures half as wide as diameter of punctures; few sparser punctate areas in posterior half; between large setiferous punctation with sparse micro-punctation; isodiamteric microsculpture deeper and more distinct than on head; surface shiny, but less shiny than on head.

Elytra: $1.25 \mathrm{~mm}$ long, $1.18 \mathrm{~mm}$ wide; with coriaceous ground-sculpture; setiferous punctation hardly visible in coarse ground-sculpture; punctures in irregular rows.

Abdomen with setiferous punctation and impunctate midline on tergites II to VII; netlike microsculpture weak; surface shiny.

Protibia: $0.58 \mathrm{~mm}$ long, $0.18 \mathrm{~mm}$ wide; nearly semicircular; 8 spines on outer edge; WLR: 2.0; in posterior aspect, comb of inner emargination visible throughout its total length; posterior face with moderately dense setation; setae nearly half as long as protibial width.

Aedeagus with smoothly rounded apical lobe ending in obtuse apex.

Etymology: The specific name trapezoides refers to the trapezoidal shape of the head.

\section{Osoriellus triangulatus n. $\mathrm{sp}$}

(Figs 71A-C, 98E)

Type material: Holotype, male: Venezuela: Prov. Falcón, Cogollal $\left(68^{\circ} 49.64^{\prime} \mathrm{W}, 10^{\circ} 54.96^{\prime} \mathrm{N}\right)$, grazed grassland with logs, 19.3.1998, leg. C. Schmidt (UIC). 
Diagnosis: Among the intermediate sized species between 4 and $5 \mathrm{~mm}$, O. triangulatus is characterised by the strongly convergent pronotum. In this respect, it can be confused with $O$. tuxtlae. But in contrast to O. tuxtlae, the pronotum is still more convergent and the surface is matt due to the distinct microsculpture, whereas the pronotum of $\mathrm{O}$. tuxtlae has no microsculpture and a polished surface.

Description: Length: $4.5 \mathrm{~mm}$. Colouration: Dark brown; legs and antennae lighter brown.

Head: $0.63 \mathrm{~mm}$ long, $0.92 \mathrm{~mm}$ wide; eyes slightly prominent and slightly shorter than temples; sides of fore-head shortly convergent to obtuse anterior angles; front edge of clypeus even; clypeal angles produced to short granules; setiferous punctation coarse and dense; punctation on midline sparser; coriaceously punctate; close to eyes, punctures partly granulate; at base of antennae, small area impunctate; netlike microsculpture dense and deep except on impunctate area at base of antennae without microsculpture; surface of vertex matt.

Antennae slightly longer than head; second antennomere oval and slightly longer than conical third; antennomeres 4 to 6 as wide as preceding antennomeres, but quadrate; antennomeres 7 to 10 wider than preceding antennomeres and increasing in width; antennomere 7 approximately quadrate; antennomere 10 slightly wider than long.

Pronotum: $0.88 \mathrm{~mm}$ long, $0.92 \mathrm{~mm}$ wide; widest at obtusely rounded anterior angles; strongly convergent to posterior angles; close to posterior angles more strongly convergent than in anterior half; lateral margin fine; in posterior half slightly wider than in anterior half; in dorsal aspect, not visible close to anterior angles; setiferous punctation coarse; in irregular rows; narrow midline impunctate; wider at anterior edge than at posterior edge; within rows, interstices between punctures shorter than diameter of punctures; between rows, interstices between punctures at least as wide as diameter of punctures; between coarse punctures with sparse micro-punctation; netlike microsculpture weaker and wider than on head; surface slightly shiny.

Elytra: $1.08 \mathrm{~mm}$ long, $0.95 \mathrm{~mm}$ wide; with rows of setiferous punctures on deep coriaceous ground-sculpture; surface matt.

Abdomen with dense and coarse setiferous punctation except impunctate dorsal midline; microsculpture weak, but dense; surface matt.

Protibia: $0.55 \mathrm{~mm}$ long, $0.18 \mathrm{~mm}$ wide; 10 spines on outer edge; WLR: 2.8; in posterior aspect, comb at inner edge visible throughout its total length; posterior face with dense setation.

Aedeagus rectangularly angulate; apical lobe long; apex obtusely rounded.

Etymology: The specific name refers to the triangular shape of the pronotum.

\section{Osoriellus tunariensis n. sp.}

(Figs 85A-C, 102C)

Type material: Holotype, male: Bolivia: Cochabamba, Villa Tunari, 800 m elevation, 17.10.1981, leg. M. Cooper (BMNH).

Diagnosis: Both the total size and the shape of the pronotum of $O$. tunariensis are similar to O. argentinus. The species can be differentiated from the other species by the large prominent eyes and the contrast between the dense microsculpture of the head and the weak pronotal microsculpture.

Description: Length: $5.6 \mathrm{~mm}$. Colouration: Black; legs and antennae lighter brown.

Head: $0.84 \mathrm{~mm}$ long, $1.26 \mathrm{~mm}$ wide; eyes prominent; distinctly longer than temples; sides of fore-head slightly emarginate to anterior angles of clypeus; anterior edge of clypeus even; setiferous punctation deep and dense; on vertex, partly coriaceously punctate; on central posterior vertex and at base of antennae impunctate; on supraocular area, punctures granulate; netlike microsculpture dense and deep; surface matt.

Antennae lost.

Pronotum: $1.14 \mathrm{~mm}$ long, $1.30 \mathrm{~mm}$ wide; widest at anterior angles; slightly convergent in even curve to shortly rounded posterior angles; lateral margin fine; finer at anterior angles than at posterior angles; anterior angles produced to very short acute teeth; setiferous punctation coarse and deep; impunctate midline widened from anterior margin to posterior margin; on average, interstices between punctures half as wide as diameter of punctures; microsculpture extremely weak; surface shiny.

Elytra: $1.40 \mathrm{~mm}$ long, $1.36 \mathrm{~mm}$ wide; with dense and deep coriaceous ground-sculpture; setiferous punctures in irregular rows; surface matt.

Abdomen with dense setiferous punctation; on tergites narrow midline impunctate; moderately weak netlike microsculpture; on impunctate midline weaker than on punctate area; surface of puntate area matt; midline shiny.

Protibia: $0.70 \mathrm{~mm}$ long, $0.26 \mathrm{~mm}$ wide; 9 spines at outer edge; WLR: 1.4; in posterior aspect, comb at inner emargination visible throughout its total length; posterior face very densely covered by yellow setae.

Aedeagus rectangularly angulate; apical lobe thick; ending in obtuse apex; inner edge of apical lobe with numerous sensillae.

Etymology: The specific name refers to the Bolivian village Villa Tunari, where the species was found. 
Osoriellus tuxtlae n. sp.

(Figs 66A-C, 98B)

Type material: Holotype, male: Mexico: Chiapas, Tenejapa ca. $30 \mathrm{mi}$. ENE Tuxtla Gutierrez, $7000 \mathrm{ft}$. $\left(92^{\circ} 22^{\prime} \mathrm{W}\right.$, $\left.16^{\circ} 50^{\prime} \mathrm{N}\right)$, Dec. 31, 1972, leg. H. Frania (AMNH).

Paratypes: Mexico: 4 females, 4 males, with same data as holotype (AMNH, UIC); San Louis Potosi, Sierra de la Abra, Sotano de la Tinaja, flood debris on mud slope, $1500 \mathrm{ft}$. from entrance, female, Feb. 18, 1970, leg. J.A.L. Cook (AMNH).

Diagnosis: The species can be differentiated from the species similar in size and absence of pronotal microsculpture, i.e. O. boliviensis, O. parumpunctatus, and O. minor, by the dense and coarse punctation. In O. tuxtlae the interstices are narrower than half of diameter of punctures, wheras in the other species the interstices between punctures are much wider than the diameter of punctures.
Description: Length: $4.6 \mathrm{~mm}$. Colouration: Dark reddish to brown; head and pronotum brown; elytra lighter red; anterior abdominal segments light red; posterior segments dark red; legs and antennae yellow.

Head: $0.60 \mathrm{~mm}$ long, $0.82 \mathrm{~mm}$ wide; eyes not prominent; as long as temples; sides of fore-head sinuate; sides of clypeus approximately parallel; clypeal angles with granules; sparsely and deeply punctate with setiferous punctures; setae pointing to middle; impunctate areas at base of antennae and on central vertex; supraocular area with denser punctation than vertex; without microsculpture; surface shiny and polished.

Antennae with second antennomere oblong and thicker than third; third antennomere conical, narrower and shorter than second; following 3 antennomeres wider than long, but not wider than third antennomere; antennomere 7 quadrate; antennomeres 8 to 10 wider than long and distinctly wider than preceding antennomeres.

Key to the species of the Osoriellus-s. str.-group

1. Species smaller than $2.9 \mathrm{~mm}$.

At least $3.0 \mathrm{~mm}$ long.

2. At least head dark red or brown.

Fore-body totally lighter, yellow, apical margin of clypeus with distinct acute teeth at outer angle.

3. Totally black, only elytra slightly dark brown, apical lobe of aedeagus acute.

O. punctatellus n. sp.

Yellow, head and posterior margin of elytra slightly darker, apical lobe of aedeagus obtuse.

4. Apical lobe of aedeagus slender, punctation of pronotum slightly finer.

O. exiguus (Notman, 1925) Apical lobe of aedeagus thick, triangular, punctation of pronotum slightly deeper.

O. indescriptus n. sp.

5. Eyes small, half as long as temples and not prominent, sides of pronotum continuously narrowed from anterior to posterior angles.

O. coruscus n. sp.

Eyes larger, as long as temples and slightly prominent, sides of pronotum slightly emarginate in front of posterior angles.

6. Smaller than $4.0 \mathrm{~mm}$

Longer than $4.0 \mathrm{~mm}$.

7 Punctation of fore-body and abdomen extremely dense and coriaceous.

O. asperatus n. $\mathrm{sp}$.

Punctation of fore-body and abdomen not coriaceous or only head coriaceously punctate.

8 Punctation of head densely coriaceous.

O. coriaceus n. $\mathrm{sp}$.

Punctation of head dense or sparse, but not coriaceous.

9 Shape of protibia asymmetric, trapezoid.

O. latitibialis n. sp.

- Shape of protibia more or less symmetric, nearly semi-circular.

10. Pronotum with isodiametric microsculpture, surface matt or slightly shiny.

Pronotum without or with weak microsculpture or remains of microsculpture, surface shiny or polished.

11. Eyes distinctly prominent, pronotum with extremely large punctures, partly depressed rows adjacent to midline. O. grossopunctatus n. sp. 
Eyes not or only very slightly prominent; row of punctures adjacent to midline not large and deep and forming partly a furrow.

12. $6^{\text {th }}$ antennomere nearly two times wider than long, only slightly narrower than $7^{\text {th }}$ antennomer.

- $6^{\text {th }}$ antennomere slightly wider than long and distinctly narrower than $7^{\text {th }}$ antennomere, posterior angles of pronotum widely rounded.

O. micros (SHARP, 1887)

13. Eyes prominent.

O. surinamensis $\mathrm{n}$. $\mathrm{sp}$.

- Eyes not prominent

14. Pronotum lighter brown than head and evenly narrowed from anterior angles to posterior angles.

O. brevicornis (NoTMAN, 1920)

- Pronotum and head black, pronotum more strongly narrowed in posterior half than in anterior half.

O. lewisi (BLACKWELDER, 1943)

15. Punctures of pronotum large, along impunctate midline in irregular rows, not more than 12 punctures in the row adjacent to midline.

Pronotum on both sides of impunctate midline with irregular finer punctation, punctures not in rows, irregular line of punctures adjacent to midline at least with 12 to 15 punctures.

16. On average larger, 3.5 - $3.9 \mathrm{~mm}$ long, pronotum with weak microsculpture and micro-punctation. .................. 17

- Not longer than $3.5 \mathrm{~mm}$, surface of pronotum polished and with fine micro-punctation. ................................... 20

17. Head and pronotum with iridescent shine.

- Head without iridescent shine, punctation of pronotum denser and deeper, distance between punctures shorter than diameter of punctures.

18. Punctation of pronotum sparse, distance between punctures as wide as diameter of punctures.

O. flaveolus n. sp.

Punctation of pronotum denser, distance between punctures in row adjacent to midline shorter than diameter of punctures.

O. huggerti n. sp.

19. Head without microsculpture, but coriaceous punctation on vertex, irregular row of pronotal punctures depressed. O. salvini (SHARP, 1887)

- Head with microsculpture, punctation on vertex dense, but not coriaceous, row of pronotal punctures not depressed. O. obtusicollis n. sp.

20. Dark brown, punctation of pronotum sparser and less deep, distance between punctures within row as wide as diameter of punctures.

O. levyi n. sp.

- Light or dark reddish and punctation denser, distance between punctures within row shorter than diameter of punctures.

21. Pronotum with weaker punctation and remains of microsculpture. O. loksai n. sp.

- Pronotum with dense and deep punctation and without remains of microsculpture; surface polished. 22

22. Anterior angles of pronotum obtuse, not produced to short teeth. O. bicolor $\mathrm{n} . \mathrm{sp}$.

- Anterior angles of pronotum acute, produced to short teeth O. ashei n. sp.

23. Punctation of fore-head as dense as on vertex, apex of aedeagus acute. O. eggersi (BernHAUER, 1904)

Punctation of fore-head sparser than on vertex, apex of aedeagus obtuse. O. humicola n. sp.

24. Between 4.0 and $4.9 \mathrm{~mm}$ long. 25

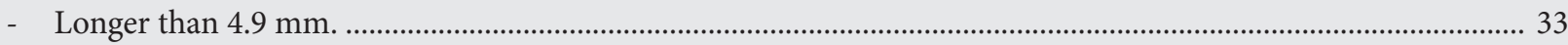

25. Pronotum with dense microsculpture, surface matt or slightly shiny. .................................................................. 30

- Pronotum without or very weak microsculpture, surface polished and shiny. ..................................................... 26

26. Eyes slightly prominent, punctation of pronotum dense, but not coriaceous. O. boliviensis n. $\mathrm{sp}$.

Eyes not prominent 
27. Pronotum sparsely punctate, distance between punctures at least as wide as diameter of punctures.

Pronotum densely punctate, interstices between punctures smaller than diameter of punctures, longer, $4.6-4.8 \mathrm{~mm}$ long.

28. Smaller, $4.1-4.2 \mathrm{~mm}$ long, row of punctures adjacent to impunctate midline not more than 6 punctures.

O. parumpunctatus n. sp.

Larger, $4.4 \mathrm{~mm}$ long, row of punctures adjacent to impunctate midline at least 9 punctures.

O. franckei (WENDELER, 1955)

9. Pronotum quadrate, posterior angles of pronotum obtuse, elytra longer than wide.

O. tuxtlae n. sp.

Pronotum wider than long, posterior angles of pronotum widely rounded, elytra quadrate.

O. minor (NotMan, 1925)

30. Eyes thick and prominent, interstices between setiferous punctures of pronotum less than half as wide as diameter of punctures.

O. multipunctatus $\mathrm{n}$. sp.

- Eyes smaller and not or only slightly prominent; pronotal punctation less dense, interstices between punctures maximum less shortly wide than diameter of punctures.

31. Pronotum trapezoidal, clypeus with two short lateral granules.

O. triangulatus n. sp.

Sides of pronotum smoothly rounded; clypeus without or with one short lateral denticle.

32. Pronotum with dense microsculpture, surface matt, irregular line of punctures adjacent to midline with more than 12 punctures.

O. rugipennis (BERNHAUER, 1910)

- Pronotum with weaker microsculpture, surface slightly shiny, irregular line of punctures adjacent to midline with 10 to 12 punctures.

O. haitiellus (DARLINGTON, 1937)

33. Pronotum with microsculpture, surface matt or slightly shiny.

Pronotum without microsculpture, surface polished or with remains of weak microsculpture, surface shiny. .......

34. Longer, $7.8 \mathrm{~mm}$ long, punctate line adjacent to impunctate midline depressed, disc of pronotum irregularly punctate. O. crassus (SHARP, 1887)

Smaller, not longer than $6.5 \mathrm{~mm}$.

35. Sides of pronotum in anterior half nearly parallel; anterior edge only 1.3 times wider than posterior edge. O. frater (LYNCH, 1884)

Sides of pronotum strongly narrowed from anterior to posterior angles, anterior edge at least 1.5 times wider than posterior edge, posterior angles obtuse.

36. Smaller species of $5.3-5.4 \mathrm{~mm}$.

O. latipes (GRAVENHORST, 1802)

Longer than $5.5 \mathrm{~mm}$.

37. Head with distinct or weak isodiametric microsculpture, surface matt or slightly shiny.

Head without microsculpture, surface polished and shiny.

O. mexicanus (BERNHAUER, 1910)

38. Pronotum more strongly trapezoid, anterior edge nearly 2 times wider than posterior edge.

O. brevipennis (Notman, 1925)

Pronotum less narrowed to posterior edge, anterior edge only 1.5 times wider than posterior edge.

39. Eyes distinctly prominent and longer than temples.

O. tunariensis n. sp.

- Eyes not prominent and as long as temples. O. argentinus (BERNHAUER, 1911)

40. At least $6.7 \mathrm{~mm}$ long.

- Smaller than $6.5 \mathrm{~mm}$.

41. Sides of pronotum evenly narrowed to posterior angles in smooth curve.

O. parcus (SHARP, 1887)

- Sides of pronotum evenly narrowed to posterior angles, pronotal shape nearly trapezoidal, lateral margin close to posterior angles widened. O. majusculus n. sp. 
42. Smaller, 4.9 - $5.4 \mathrm{~mm}$ long, microsculpture of pronotum weak, surface shiny.

- $\quad$ Longer than $5.5 \mathrm{~mm}$, microsculpture of pronotum dense, surface matt. .............................................................. 46

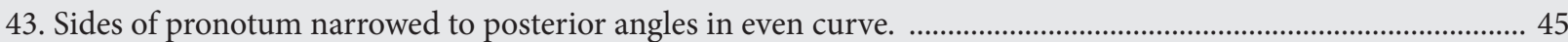

Sides of pronotum evenly narrowed from anterior angles to posterior angles, shape trapezoid.

44. Posterior angles of pronotum obtuse and rounded, sides of fore-head narrowed to anterior angles in slight sinuate curve.

O. trapezoides n. sp.

- Posterior angles of pronotum nearly rectangular, sides of fore-head narrowed to anterior angles in deep emarginate curve.

O. rubripennis n. sp.

45. More slender, sides of pronotum nearly parallel in anterior half, lateral margin fine throughout its total length. .. O. debilis (SHARP, 1887)

- Broader, sides of pronotum also curved in anterior half, lateral margin slightly widened close to posterior angles.

O. seriatus n. sp.

46. Pronotum evenly narrowed from anterior to posterior angles; shape of pronotum trapezoidal.

O. verhaaghi n. $\mathrm{sp}$.

Shape of pronotum different, pronotal sides curved

47

47. Sides of pronotum emarginate close in front of posterior angles; sides shortly in front of posterior angles nearly parallel, lateral margin in front of posterior angles distinctly widened, two very similar species.

48

- Sides of pronotum narrowed to posterior angles in even curve, posterior angles obtuse, lateral margin in front of posterior angles not widened.

48. Slightly larger, $6.4 \mathrm{~mm}$ long, microsculpture less distinct and surface slightly shiny, apex of aedeagus obtuse. ...... O. fumarius n. sp.

- Slightly shorter. $6.0 \mathrm{~mm}$ long, microsculpture deeper and surface matt, apex of aedeagus acute.

O. caliginosus $\mathrm{n}$. sp.

49. Pronotum mostly with longitudinally reticulate microsculpture, only near anterior edge with netlike microsculpture; elytra with weak ground sculpture, punctation distinctly visible. O. rougemonti $\mathrm{n} . \mathrm{sp}$

Pronotum with isodiametric microsculpture; surface matt, ground sculpture of elytra more distinct and, thus, punctation less visible. 50

50. Elytra with dense and deep microsculpture, surface extremely matt, inner edge of apical aedeagus with numerous sensillae.

O. opacus n. $\mathrm{sp}$.

Elytra with ground sculpture, but without dense and deep microsculpture, surface more or less shiny, aedeagus at inner edge with single row of few sensillae.

O. schwarzi (NotMAN, 1925)

Pronotum: $0.88 \mathrm{~mm}$ long, $0.88 \mathrm{~mm}$ wide; widest at anterior angles; slightly convergent to posterior angles; posterior angles smoothly rounded; lateral margin fine; in dorsal aspect, visible in its total length; punctation coarse and dense; in irregular rows of 10 to 12 setiferous punctures; on average, interstices between punctures narrower than half of diameter of punctures; wide midline impunctate; sparse micro-punctures between coarse setiferous punctures; without distinct microsculpture; only with remains of weak striae; in most parts, surface shiny and polished.

Elytra: $1.00 \mathrm{~mm}$ long, $0.88 \mathrm{~mm}$ wide; densely and coarsely punctate; on average, interstices between setiferous punctures half as wide as diameter of punctures.

Abdomen as densely and coarsely punctate as elytra; with wide impunctate midline.
Protibia: $0.50 \mathrm{~mm}$ long, $0.15 \mathrm{~mm}$ wide; 9 spines at lateral edge; WLR: 5.0; in posterior aspect, comb of inner emargination widely covered; posterior face with moderately dense setation.

Aedeagus angulate; apical lobe thin and elongate; 1.5 times as long as basal lobe and with acute apex.

Etymology: The specific name refers to the region of Tuxtla, where the species was collected.

Osoriellus verhaaghi $\mathrm{n}$. sp.

(Figs 88A-C, 101D)

Type material: Holotype, male: Peru: Huanuco, Panguana (745 $\left.55^{\prime} \mathrm{W}, 9^{\circ} 36^{\prime} \mathrm{S}\right)$, rain forest, Jun. 1984, leg. M. Verhaagh (UIC). 
Paratypes: Peru: Huanuco, Panguana $\left(74^{\circ} 55^{\prime} \mathrm{W}, 9^{\circ} 36^{\prime} \mathrm{S}\right)$, 26.5.-23.6.1984, leg. M. Verhaagh (UIC); rain forest, female, June-July 1975, leg. W. Hanagarth (UIC); same location, but Cocha, 5 females, 1 male, June-July 1975, June-Sept. 1975, Sept. 1975, Jun.-Oct. 1976, leg. W. Hanagarth (UIC, BMNH, AMNH); same location, but trop. grassland, pitfall trap \#13, female, 26.5.23.6.1984, leg. M. Verhaagh (UIC); same location, but rain forest, pitfall trap 3, female, Jun. 1984, 21.1.18.2.1984, leg. Verhaagh (UIC); Tambopata Prov. Madre de Dios Dept., $15 \mathrm{~km}$ NE Puerto Maldonado, Reserva Cuzco Amazónico (69 $\left.03^{\circ} \mathrm{W}, 12^{\circ} 33^{\prime} \mathrm{S}\right), 200 \mathrm{~m}$ elevation, collected by flight intercept trap, Plot \#Z1E13, male, 20.6.1989, leg. J.S. Ashe, R.A. Leschen (KNHM); same location and date, but Plot \#Z2E17, male, 28.6.1989, leg. D. Silva, R.A. Leschen (KNHM); Bolivia: Santa Cruz Dept., 3.7 km SSE Buena Vista, Hotel Flora y Fauna $\left(63^{\circ} 33.15^{\prime} \mathrm{W}, 17^{\circ} 29.95^{\prime} \mathrm{S}\right), 400-450 \mathrm{~m}$ elevation, collected by flight intercept trap, secondary forest, female, 2-9.11.2002, leg. R.A. Leschen (KNHM); Cochabamba Prov., Cochabamba, 67.5 km NE Est. Biol. Valle de Sajita, Univ. de San Simon $\left(64^{\circ} 47.52^{\prime} \mathrm{W}, 17^{\circ} 06.33^{\prime} \mathrm{S}\right)$, $300 \mathrm{~m}$ elevation, collected by flight intercept trap, 1 male, 1 female, 9.-13.2.1999 and 7.-9.2.1999, leg. F. Genier, \#BOL 1G99 069, BOL 1G99 042 (KNHM).

Diagnosis: Among the similarly sized species without digitate protibial outer edge, O. verhaaghi is characterised by the slightly emarginate sides in front of the posterior angles. In this respect, it resembles O. fumarius and O. caliginosus, but these species are larger and the pronotal emargination is much deeper. Additionally, the shortly produced teeth at the outer angles of the clypeus are absent in O. fumarius and O. caliginosus.

Description: Length: $6.3 \mathrm{~mm}$. Colouration: Black, legs and antennae brown.

Head: $0.90 \mathrm{~mm}$ long, $1.30 \mathrm{~mm}$ wide; eyes not prominent; as long as temples; sides of fore-head deeply sinuate; anterior angles of clypeus produced to short acute teeth; anterior edge of clypeus between lateral teeth even; setiferous punctation moderately dense and deep; density of punctation irregular; on average, interstices between punctures two to three times as wide as diameter of punctures; large area at base of antennae, small area on posterior vertex, and transverse area on posterior vertex impunctate; yellow setae hardly reaching adjacent puncture; supraocular and postoculare area with granulate punctures and short striae; distinct netlike microsculpture; surface matt.

Antennae shortly longer than head; second antennomere elongate and oval, slightly longer than conical third; following three antennomeres not wider than preceding antennomeres, but approximately quadrate, antennomeres 7 to 10 distinctly wider than preceding antennomeres, but also quadrate.

Pronotum: $1.16 \mathrm{~mm}$ long, $1.30 \mathrm{~mm}$ wide; widest at anterior angles; evenly narrowed to posterior angles; posterior angles obtusely rounded; lateral margin fine; slightly widened to posterior angles; in dorsal aspect, not visible close to anterior angles; setiferous punctation deep and moderately dense; impunctate midline widened posteriad; on average, interstices between punctures twice as wide as diameter of punctures; yellow setae short; shorter than diameter of punctures and interstice between punctures combined; between normal coarse punctures with micro-punctation; distinct netlike microsculpture; surface matt.

Elytra: $1.50 \mathrm{~mm}$ long, $1.44 \mathrm{~mm}$ wide; setiferous punctation moderately deep and dense; in irregular rows; coriaceous ground-sculpture weak; setae as short as on pronotum.

Abdomen with dense setiferous punctation; setae distinctly longer than on fore-body; netlike microsculpture distinct; surface matt; lateral punctures on tergite VII with striae.

Protibia: $0.66 \mathrm{~mm}$ long, $0.23 \mathrm{~mm}$ wide; 9 spines on outer edge; apical spines inserted on short digits; WLR: 1.47; in posterior aspect, comb of inner emargination visible throughout its total length; posterior face densely covered with long yellow setae.

Aedaegus angulate in nearly rectangular angle; basal lobe longer than apical lobe; apex obtuse; on inner edge with numerous sensillae.

Etymology: The specific name honours one of the collectors of the species, Dr. M. Verhaagh, from the Museum in Karslruhe, Germany, who collected intensively in the Panguana region.

\section{Group of remaining species}

All species that could not be placed in one of the groups described before, are placed into this group. They have a setiferous punctation that separates the species of this group from the species of the O.-guiananus-group. In contrast to the O.-s. str.-group, the apical part of the protibia is strongly digitate. The aedeagus may be symmetric or asymmetric with a lateral opening. The lateral pronotal margin can be evenly curved from anterior to posterior angles, sinuate in front of the posterior angles or slightly widened in the posterior half. The size varies from intermediately long to long compared to other species of the genus.

\section{Description of the species}

\section{Osoriellus acutus n. sp.}

(Figs 106A-C, 123F)

Type material: Holotype, male: Peru: Dept. Loreto, Campamento San Jacinto $\left(75^{\circ} 51.77^{\prime} \mathrm{W}, 2^{\circ} 18.75^{\prime} \mathrm{S}\right)$, 175-215 m elevation, collected by flight intercept trap, 9.7.1993, leg. R. Leschen, \#66 (KNHM). 
Paratypes: Peru: 1 male, with same data as holotype, but 5.7.1993, 3 females, 2. and 3.7.1993; 1 male, 1 female, Dept. Loreto, Teniente Lopez $\left(76^{\circ} 06.92^{\prime} \mathrm{W}, 2^{\circ} 35.66^{\prime} \mathrm{S}\right)$, 210-240 m elevation, collected by flight intercept trap, 22 . and 24.7.1993, leg. R. Leschen (KNHM, UIC).

Diagnosis: Among the species of similar size, O. acutus is characterised by the fine punctation of the pronotum, the long acute anterior angles of the pronotum, and the digitate outer edge of the protibia. A similarly digitate outer edge of the protibia is also found in O. longipunctatus and O. guiananus of the O.-guianus-group. But, in these two species the punctation is much coarser and the shape of the pronotum is more trapezoidal, whereas it is smoothly curved in O. acutus. Within the group of the remaining species, $O$. digitatus has a similarly deep digitate protibia, but the species is smaller with $3.8 \mathrm{~mm}$ than O. acutus with $5.1 \mathrm{~mm}$.

Description: Length: $5.1 \mathrm{~mm}$. Colouration: Black; legs dark brown, antennae light brown.

Head: $0.58 \mathrm{~mm}$ long, $0.93 \mathrm{~mm}$ wide; eyes prominent; distinctly longer than temples; fore-head deeply sinuate; lateral sides of clypeus nearly parallel; anterior edge of clypeus even; angles of clypeus produced to short acute teeth; punctation irregularly dense and deep; without setae; punctation of fore-head finer and sparser than on posterior vertex, but partly granulate; punctation of posterior vertex dense and partly coriaceous; interstices between punctures distinctly shorter than diameter of punctures; on supraocular area punctation coriaceous and striate with few punctures with longer setae; one pair of punctures with long setae on vertex close to neck; area at base of antennae impunctate; fore-head with dense isodiametric microsculpture; vertex with weaker microsculpture and area close to neck without microsculpture.

Antennae nearly as long as head and half of pronotum combined; second antennomere oval; third conical and nearly twice as long as second; following antennomeres increasing in width, but approximately quadrate.

Pronotum: $1.02 \mathrm{~mm}$ long, $1.08 \mathrm{~mm}$ wide; widest near anterior angles; convergent to posterior angles in smooth curve; in front of posterior angles with short and slight emargination; anterior angles produced to short acute teeth; posterior angles laterally produced to short swollen triangle; lateral margin distinct; in dorsal aspect covered close to anterior angles; widened close to posterior angles; punctation irregularly dense; punctures larger and deeper than on head; on disc, interstices between punctures as wide as diameter of punctures; close to anterior and posterior edges, punctation sparser; irregular and indistinct midline in posterior half impunctate; behind anterior margin and in posterior half with transverse row of setiferous punctures; normal punctures with short setae; between normal punctures with dense micropunctation; weak longitudinal microsculpture; surface slightly shiny.
Elytra: $1.14 \mathrm{~mm}$ long, $1.16 \mathrm{~mm}$ wide; widest in posterior third, but approximately parallel; shoulders approximately rectangular; punctation much finer than on pronotum; in irregular rows; with deep coriaceous ground-sculpture; surface slightly shiny.

Abdomen on tergites III-VI with sparse and fine punctation, but few larger setiferous punctures; tergites VII and VIII with denser punctation and at least laterally with elongate punctures.

Protibia: $0.54 \mathrm{~mm}$ long, $0.15 \mathrm{~mm}$ wide; with 8 spines on outer edge; apical spines on long digits; WLR: 0.30; in posterior aspect, inner emargination with comb visible throughout its total length; posterior face sparsely covered by long yellow setae.

Aedeagus angulate in nearly rectangular angle; apical lobe as long as basal lobe; apical lobe shortly narrowed to obtusely rounded apex; laterally close to apex and inner edge with row of sensillae.

Etymology: The specific name acutus derived from the same Latin word meaning acute and refers to the laterally acute posterior angles of the pronotum.

\section{Osoriellus adustus n. sp.}

(Figs 108A-C, 123E)

Type material: Holotype, male: Peru: Loreto Prov., Iquitos $\left(73^{\circ} 14^{\prime} \mathrm{W}, 3^{\circ} 44^{\prime} \mathrm{S}\right), 90 \mathrm{~m}$ elevation, collected in leaf litter in the forest, 8.5.1992, leg. J. Danoff-Berg (KNHM).

Paratype: Peru: 1 female with same data as holotype (UIC).

Diagnosis: The species is characterised by the deep and dense microsculpture of the pronotum and the digitate protibibia with a WLR of 1.00 . Species with a similarly deep pronotal microsculpture are larger such as O. opacus and O. opacinotus or have additionally no digitate protibia.

Description: Length: 4.5 long. Colouration: Dark brown, nearly black; legs and antennae reddish brown.

Head: $0.55 \mathrm{~mm}$ long, $0.94 \mathrm{~mm}$ wide; eyes prominent; nearly twice as long as temples; sides of fore-head convergent to anterior angles of clypeus in smooth concave curve; anterior edge of clypeus even; punctation with moderately deep and irregularly dense punctation; punctures without setae except one pair of setae on clypeus, one pair on vertex close to neck, and several setae on supraocular area; large area at base of antennae impunctate; punctation on vertex much denser than on clypeus; on vertex, interstices between punctures aproximately as wide as diameter of punctures; on supraocular area, punctation partly coriaceous and with striae; isodiametric microsculpture dense and deep; surface matt.

Antennae slightly shorter than head and half of pronotum combined; second antennomere elongate; approximately 1.5 times as wide as conical third antennomere; fourth and fifth antennomere as wide as third; sixth anten- 
nomere quadrate and slightly wider than preceding antennomeres; following antennomeres distinctly wider than preceding antennomeres; quadrate.

Pronotum: $0.94 \mathrm{~mm}$ long, $1.05 \mathrm{~mm}$ wide; widest at anterior angles; anterior angles slightly produced; sides convergent to posterior angles in smooth even curve; posterior angles distinct, but obtuse; lateral margin fine in anterior half, slightly thicker in posterior half; shortly in front of posterior angles, slightly widened; in dorsal aspect, covered close to anterior angles; punctation sparser and deeper than on head; with short setae; on average, interstices between punctures at least twice as wide as diameter of punctures; punctures denser within irregular row adjacent to moderately wide impunctate midline; isodiametric microsculpture deep and dense; surface matt.

Elytra: $1.13 \mathrm{~mm}$ long, $1.08 \mathrm{~mm}$ wide; shoulders rounded; sides sligthly widened posteriad; widest in posterior third; punctation similarly dense and deep as on pronotum; in irregular rows; coriaceous ground-sculpture weak; isodiametric microsculpture dense, but weaker than on pronotum; surface slightly shinier than on pronotum.

Abdomen with sparse and fine punctation; punctures without setae except few setae in transverse row; netlike microsculpture weaker than on fore-body; surface shiny. Protibia: $0.57 \mathrm{~mm}$ long, $0.15 \mathrm{~mm}$ wide; slender; outer edge with seven spines; apical spines inserting on moderately long digits; WLR: 1.0; in posterior aspect, inner emargination with comb visible throughout its total length; posterior face sparsely covered by long yellow setae.

Aedeagus thick; apical lobe smoothly curved; apex widely rounded; inner edge of apical lobe with nine sensillae.

Etymology: The specific name adustus derived from the same Latin word meaning brownish and refers to the dark brown colouration.

\section{Osoriellus carinicollis (Notman, 1925) new combination (Figs 104A-C, 123A)}

Osorius carinicollis Notman, 1925: 7

Typ material examined: Guatemala: Alta Vera Paz, Cacao, Trece Aguas, $\left(89^{\circ} .45^{\prime} \mathrm{W}, 15^{\circ} 24^{\prime} \mathrm{N}\right), 25.3$., female, leg. Barber \& Schwarz (holotype in NMNH).

Further material examined: Mexico: Chiapas, Ruines de Palenque $\left(91^{\circ} 58^{\prime} \mathrm{W}, 17^{\circ} 29^{\prime} \mathrm{N}\right)$, nr. Group IV, from stump litter, 7 specimens, 6.4.1974, leg. C. Altieri (AMNH, UIC); Ruines, litter, Berlese sample, 2 specimens, 25.7.1973, leg. J. Reddell (AMNH); Ruines, 2 specimens, 3.4.1974, leg. C. Alteri (AMNH); Veracruz, Cordoba $\left(96^{\circ} 55^{\prime} \mathrm{W}, 18^{\circ} 53^{\prime} \mathrm{N}\right), 5$ specimens, 4.8.1969, leg. J. Peck (AMNH); Paraje Nueve Nacimiento, tropical evergreen forest, Berlese sample, 3 specimens, 7.8.1969, leg. J. Peck (AMNH); Fortin de las Flores $\left(97^{\circ} 00^{\prime} \mathrm{W}, 18^{\circ} 54^{\prime} \mathrm{N}\right)$,
5.8.1969, leg. J. Peck (AMNH); Tamaulipas, Rancho del Cielo, Gomes Farias $\left(98^{\circ} 55.50^{\prime} \mathrm{W}, 21^{\circ} 09.56^{\prime} \mathrm{N}\right), 3$ specimens, 4.07.1969, leg. J. Peck (AMNH); Queretaro, $18 \mathrm{mi}$. E Landa de Matamoros $\left(100^{\circ} 23^{\prime} \mathrm{W}, 20^{\circ} 35^{\prime} \mathrm{N}\right)$, pine oak leaf litter, 1760 m elevation, 2 specimens, 14.7.1969, leg. J. Peck (AMNH); Chiapas, Ocosingo, Nahá Selva Lacandona, mixed montane forest litter, 2 specimens, 13.7.2003, leg. R. Anderson (KNHM); Oaxaca, Tlaxiaco (97 $\left.40^{\prime} \mathrm{W}, 17^{\circ} 16^{\prime} \mathrm{S}\right), 7 \mathrm{~km} \mathrm{~S}, 2000$ m elevation, 1 specimen, 10.10.1990, leg. R. Baranowski (SMNH); Valle Nacional $\left(96^{\circ} 18^{\prime} \mathrm{W}, 17^{\circ} 46^{\prime} \mathrm{N}\right), 21 \mathrm{~km} \mathrm{~S}, 1200 \mathrm{~m}$ elevation, 7 specimens, 10.09.1986, leg. R. Baranowski (SMNH, UIC); 24-25 km S, $1300 \mathrm{~m}$ elevation, 2 specimens, 14.09.1986, leg. R. Baranowski (SMNH); 23 km SW Valle National, $\mathrm{km} \mathrm{76}$, cloud forest leaf litter, Berlese, 1 specimen, 28.07.1992, leg. R. Anderson (KNHM); Jalapa, $2.3 \mathrm{~km} \mathrm{~S}$ on Coatepec road, forest litter, 1 specimen, 13.7.1992, J.S. Ashe\&H. Frania(KNHM); samelocation, but $1.1 \mathrm{~km} \mathrm{~S}$ on Coatepec road, leaf litter in rivine, $1280 \mathrm{~m}$ elevation, 1 specimen, 12.7.1992, leg. J.S. Ashe (KNHM); same location, but $2.3 \mathrm{~km} \mathrm{~S}$ on Coatepec road, stream side litter, $1380 \mathrm{~m}$ elevation, 1 specimen, 13.7.1992, leg. J.S. Ashe (KNHM); Chichen Itza, 11.9.1952, leg. J. \& D. Pallister, C.R. Vose Fund, Explorers club (AMNH); Belize: Orange Walk, Rio Bravo Conservation area, 1 female, 18.4.1996, leg. C.E. Carlton (UIC); Orange Walk, 9 specimens, 25. + 26.4.1996, leg. C. Carlon \& V. Moseley, collected by flight intercept trap (KNHM, UIC); 2 specimens, 26.4.1996 and 18.4.1996, leg. C. Carlon \& V. Moseley, collected by berlese extraction (KNHM); Alta Verapaz 6 km W Tactic, sifting litter under bushes of road side, tropical montane foest, 1430 m elevation, 3 males, 22.11.1991, leg. R. Baranowski (SMNH); Costa Rica: Puntarenas, Rincon de Osa, female, 14.-26.7.1969, leg. T. Schuh \& J. Crane; Heredia, $3.2 \mathrm{~km} \mathrm{SE}$, La Selva, $100 \mathrm{~m}$ elevation, flight interc., 2 specimens, 11.3, 24.3.1992, leg. W. Bell (KNHM); Guanacaste, Cacao Biol. Stn. $\left(85^{\circ} 27.0^{\prime} \mathrm{W}, 10^{\circ} 56.0^{\prime} \mathrm{N}\right)$, leaf litter, Berlese, 1 specimen, 4.5.1995, leg. R. Anderson (KNHM); Panama: Colon $\left(79^{\circ} 45^{\prime} \mathrm{W}, 9^{\circ} 07^{\prime} \mathrm{N}\right)$, Parque Nac. Soberania, Pipeline Rd. km 6.1, flight intercept trap, 7.6.1995, leg. J.S. Ashe (KNHM); Parque Nac. Soberania, Pipeline Rd., flight intercept trap, 5 specimens, 18.5.1995, 20.05.1995, 23.05.1995, leg. J. Jolly (KNHM); $6.1 \mathrm{~km}$ on Pipline Rd. nr. Gamboa, flight intercept trap, 1 specimen, 29.5.1995, leg. J.S. Ashe (KNHM); Parque Nac. Soberania, Pipeline Rd. km 2.0, 1 specimen, 16.5.1995, leg. J.S. Ashe (KNHM); same location, flight intercept trap, 1 specimen, 23.5.1995, leg. J. Jolly \& C. Chaboo (KNHM); same location, but $\mathrm{km} 5.3\left(79^{\circ} 45^{\prime} \mathrm{W}, 9^{\circ} 07^{\prime} \mathrm{N}\right), 40 \mathrm{~m}$ elevation, 29.-31.5.1995, leg. J.S. Ashe (KNHM); Chiriqui, La Fortuna, Hydro Trail $\left(82^{\circ} 14^{\prime} \mathrm{W}, 8^{\circ} 42^{\prime} \mathrm{N}\right), 1150 \mathrm{~m}$ elevation, flight interc., 3 specimens, 31.5.-2.6., 23.5.9.6.1995, leg. J.S. Ashe \& R. Brooks (KNHM); Panama, Barro Colorado Isd. (79 $\left.51^{\prime} \mathrm{W}, 9^{\circ} 11^{\prime} \mathrm{N}\right)$, flight interc., 1 specimen, 24.8.1994, leg. D. Banks (KNHM); Ecuador: Pichincha, Tinalandia, Santo Domingo, $16 \mathrm{~km} \mathrm{E}$ $\left(79^{\circ} 03.39^{\prime} \mathrm{W}, 0^{\circ} 16.53^{\prime} \mathrm{S}\right), 750 \mathrm{~m}$ elevation, flight interc., 2 specimens, 27.3.1999, leg. R.W. Brooks \& D. Brzoska 
(KNHM); Maquipucuna, 50 km NW Quito, $1720 \mathrm{~m}$ elevation, flight interc., 1 specimen, 23.12.1991, leg. C.E. Carlton \& R. Leschen (KNHM); Mindo, $10.6 \mathrm{~km} \mathrm{~W}$ Mindo Road (78 $\left.{ }^{\circ} 45.14^{\prime} \mathrm{W}, 0^{\circ} 04.23^{\prime} \mathrm{S}\right), 1375 \mathrm{~m}$ elevation, flight interc., 3 specimens, 29.3.1999, leg. R.W. Brooks \& D. Brzoska (KNHM); 45 km NW Quito, Macquipucuna Station, 1600-1650 m elevation, flight interc., 1 specimen, 18.4.-5.5.1996, leg. P. Hibbs (KNHM); Esmeraldas, Bilsa, flight intercept trap, 1 specimen, 10.5.1996, leg. P. Hibbs (KNHM); Peru: Madre de Dios, Manu National Park, Cocha Salvador, Reserved Zone $\left(71^{\circ} 31.36^{\prime} \mathrm{W}\right.$, $\left.12^{\circ} 00.13^{\prime} \mathrm{S}\right), 310 \mathrm{~m}$ elevation, flight interc., 1 specimen, 20.-21.10.2000, leg. R.W. Brooks (KNHM); Loreto, ort: Teniente Lopez, $1.5 \mathrm{~km} \mathrm{~N}\left(76^{\circ} 06.92^{\prime} \mathrm{W}, 2^{\circ} 35.66^{\prime} \mathrm{S}\right)$, fruit fall, $210-240 \mathrm{~m}$ elevation, 1 specimen, 17.7.1993, leg. R. Leschen (KNHM).

Diagnosis: The dense and deep punctation of the pronotum and the elytra of O. carninicollis is similar as in O. eggersi, but $O$. carinicollis is smaller and has a digitate protibia. The sides of the pronotum are slightly more evenly convergent to the posterior angles. The elytra of O. carinicollis are slightly longer than wide, but quadrate in O. eggersi. The apical lobe of the aedeagus is smoothly curved to an acute apex, whereas in O. eggersi the apical lobe is thicker and dorsally slightly emarginate. The species seems to be variable in size and shape of the aedeagus. In some specimens the apical lobe is slightly more curved than in others.

Description: Length: 3.0 - $3.5 \mathrm{~mm}$. Colouration: Brown; elytra slightly lighter; legs and antennae yellow.

Head: $0.30 \mathrm{~mm}$ long, $0.65 \mathrm{~mm}$ wide; eyes slightly prominent; slightly longer than temples; anterior edge of clypeus even; without granules at angles; setiferous punctation dense and deep; interstices between punctures less than one-fourth as wide as diameter of punctures; small areas on vertex and at base of antennae impunctate; surface without microsculpture; shiny.

Antennae with second antennomere oblong, slightly longer than wide; third and fourth antenomeres distinctly shorter and smaller than second; fourth and fifth antennomeres slightly wider than two preceding antennomeres; quadrate; antennomeres 6 to 11 distinctly wider than long.

Pronotum: $0.60 \mathrm{~mm}$ long, $0.70 \mathrm{~mm}$ wide; widest at anterior edge; slightly convergent to posterior edge; posterior angles obtuse; lateral and posterior margin narrow; in dorsal aspect, lateral margin hardly visible at anterior angles; setiferous punctation as dense and deep as on head; moderately wide midline impunctate; setae pointing posteriad; surface without microsculpture; shiny.

Elytra: $0.80 \mathrm{~mm}$ long, $0.70 \mathrm{~mm}$ wide; with similar dense and deep setiferous punctation as on pronotum; setae pointing posteriad; in contrast to surface of pronotum, surface with weak coriaceous ground-sculpture and matt.
Abdomen with dense and deep setiferous punctation; setae pointing posteriad; posterior abdominal segments with indistinct impunctate midline.

Protibia: $0.44 \mathrm{~mm}$ long. $0.13 \mathrm{~mm}$ wide; with 8 spines on outer edge; apical spines inserted on moderately long digits; WLR: 0.60; posterior face sparsely covered by yellow setae.

Aedeagus slender and straight; apical lobe slightly curved; ending in acute apex; few sensillae on inner edge of apical lobe.

\section{Osoriellus cordovensis (BERNHAUER 1910) new combination \\ (Figs 109A-C, 123C)}

Osorius cordovensis BeRnHAUER, 1910: 360

Type material examined: Mexico: Veracruz, Cordoba $\left(18^{\circ} 52^{\prime} \mathrm{N}, 96^{\circ} 55^{\prime} \mathrm{W}\right)$ male without further data (holotype in $\mathrm{FMNH}$ ).

Further material examined: Mexico: Union Juarez, NW slope Vulc. Tacaná, leaf litter trop. rain forest, Rio de Finca Muxbal (GUAT), $1430 \mathrm{~m}$ elevation, 3 males, 3 females, 21.12.1976, H. Frania \& D. Proctor (AMNH, UIC); Puebla, Santa Lucia, $8 \mathrm{~km}$ SW Cuetzalan (97³1.0'W, $\left.20^{\circ} 01.60^{\prime} \mathrm{N}\right)$, female, 25.12.1973, leg. J. Reddell (AMNH); Jalisco, $4 \mathrm{mi}$ W Mazamitla $\left(103^{\circ} 01.22^{\prime} \mathrm{W}, 19^{\circ} 54.88^{\prime} \mathrm{N}\right)$, 2300 m elevation, 16.10.1950, leg. R.F. Schmith; Chiapas, San Juan Pananá $\left(92^{\circ} 30.41^{\prime} \mathrm{W}, 15^{\circ} 23.92^{\prime} \mathrm{N}\right)$, Cultivo de café y Selva Med. Per., en hojarasca y rocas de riachuelo, 1 specimen, 22.11.1999, leg. J. Marquez (JMC); Tlayacapan $\left(98^{\circ} 58.49^{\prime} \mathrm{W}, 18^{\circ} 57.17^{\prime} \mathrm{N}\right)$, Morelos, Camino a Sta Catarina, Zone 4 Selva baja ceducifolia, ex hojaresca, 1 specimen, 2.11.1996, leg. J. Marquez (JMC); Zacualtipan, cam. a StO. Domingo, Bosque mesófilo de montana, en troncos, 1 specimen, 29.12.2003, leg. J. Marquez (JMC); Hidalgo, Tlanchinol, $4.4 \mathrm{~km} \mathrm{~N}$., Hwy 105, under bark/logs, $1420 \mathrm{~m}$ elevation, 2 specimens, 6.7.1992, leg. J.S. Ashe (SEM); Vercaruz, Catemaco, $32 \mathrm{~km} \mathrm{~N}$, 1 specimen, 3.1.1982, leg. E.M. May (KNHM); 1 male, 2 females without more data (SDEI); Nicaragua: Granada $\left(85^{\circ} 57^{\prime} \mathrm{W}, 11^{\circ} 55^{\prime} \mathrm{N}\right)$, Res. Nat. Volcan Mombacho, under bark, 1 specimen, 2.02.2000, leg. J. Marquez (JMC).

Diagnosis: The species is very similar to O. mexicanus in the size, the shape of the pronotum, and the absent microsculpture of the head and pronotum. It can be differentiated from that species by the darker colour, the denser punctation of the pronotum, and the digitate protibia.

Description: Length: $5.3 \mathrm{~mm}$, Colouration: Dark brown; posterior edge of pronotum and elytra reddish; legs and antennae yellow.

Head: $0.75 \mathrm{~mm}$ long, 0.90 wide; coarsely and densely punctate except wide midline and moderately large 
area at base of antennae; interstices between setiferous punctures much shorter than diameter of punctures; supraoculare space coriaceously punctuate; surface without microsculpture and polished except postocular vertex with dense netlike microsculpture and matt surface.

Antennae with second and third antennomeres equally long, fourth to sixth antennomeres approximately quadrate; following antenomeres distinctly thicker.

Pronotum: $0.95 \mathrm{~mm}$ long, $1.00 \mathrm{~m}$ wide; widest at anterior angles; evenly convergent to posterior angles; posterior angles obtusely rounded; lateral margin extremely fine; in dorsal aspect, nearly invisible in anterior third; setiferous punctation coarse and deep; partly coriaceous; interstices between punctures less than half the diameter of punctures; on each side of smooth midline with row of approximately 11 punctures; laterally, punctures in irregular rows; surface without microsculpture, but with sparse micro-punctation; polished.

Elytra: $1.10 \mathrm{~mm}$ long, $1.10 \mathrm{~mm}$ wide; with coriaceous ground-sculpture and rows of deep and dense punctures; interstices between punctures much shorter than diameter of punctures; surface slightly shiny.

Abdomen distinctly and densely punctate except moderately wide midline; each puncture with long yellow seta.

Protibia: $0.73 \mathrm{~mm}$ long, $0.23 \mathrm{~mm}$ wide; thick, nearly semi-circular; with 10 spines on outer edge; apical three spines inserted on moderately long digits; WLR: 0.67; in posterior aspect, comb at inner emargination visible throughout its total length; posterior face densely coverd by thick yellow setae.

Aedeagus angulate in nearly rectangular angle; apical lobe long and slender and slightly sinuate to apex; apex nearly acute; inner side of apical lobe with three sensillae at middle.

\section{Osoriellus digitatus $\mathrm{n} . \mathrm{sp}$.}

(Figs 117A-C, 124D)

Type material: Holotype, male: Peru: Loreto, Campamento San Jacinto ( $\left.75^{\circ} 51.77^{\prime} \mathrm{W}, 2^{\circ} 18.75^{\prime} \mathrm{S}\right), 175-215 \mathrm{~m}$ elevation, collected in flood debris, Qd. 16, 2.7.1993, leg. R. Leschen (KNHM).

Diagnosis: Concerning the long digits of the protibia, the species resembles $O$. acutus, but both species can be easily differentiated by the shape of the head and the pronotum. The shape of the pronotum of $O$. digitatus resembles that of $O$. opticus and O. rectangulus, but these species have much shorter protibial digits.

Description: Length: $3.8 \mathrm{~mm}$. Colouration: Dark brown; clypeus and narrow posterior edge of pronotum light reddish; abdomen slightly lighter brown; legs and antennae light yellowish brown.

Head: $0.43 \mathrm{~mm}$ long, $0.78 \mathrm{~mm}$ wide; eyes prominent; nearly twice as long as temples; sides of fore-head convergent to anterior angles in smooth concave curve; anterior edge of clypeus even; setiferous punctation moderately deep and dense; on average, interstices between punctures as wide as diameter of punctures; yellow setae approximately as long as interstices between punctures; only few setae of supraocular area much longer; midline and area at base of antennae impunctate; on supraocular area punctation much denser, but not coriaceous; isodiametric microsculpture weak; surface slightly shiny.

Antennae as long as head and half of pronotum combined; second antennomere oval and longer than wide; as long as conical third antennomere; third antennomere one fourth longer than wide; antennomeres four to six slightly increasing in width; following antennomeres distinctly wider than preceding antennomeres, but all approximately quadrate. Pronotum: $0.77 \mathrm{~mm}$ long, $0.90 \mathrm{~mm}$ wide; widest at anterior angles; evenly convergent to obtuse posterior angles; lateral margin distinct; in dorsal aspect, visible throughout its total length; widened close to posterior angles; setiferous punctation similarly deep and dense as on head, but punctures slightly larger; on average, interstices between punctures as wide as diameter of punctures; yellow setae as long as diameter of punctures; impunctate midline in posterior half wider than in anterior half; isodiametric microsculpture weak; surface slightly shiny.

Elytra: $0.93 \mathrm{~mm}$ long, $0.88 \mathrm{~mm}$ wide; shoulders rounded; sides slightly widened to posterior third; setiferous punctation similar to pronotum; in irregular rows; coriaceous ground-sculpture deep, but punctures distinctly visible; surface less shiny than on pronotum. Abdomen with dense setiferous punctation; punctation much denser than on fore-body; without microsculpture; surface slightly shiny than fore-body.

Protibia: $0.47 \mathrm{~mm}$ long, $0.12 \mathrm{~mm}$ wide; with six spines at outer edge; apical spines inserted on very long digits; WLR: 0.33; in posterior aspect, inner emargination with comb visible throughout its total length; posterior face sparsely covered with long yellow setae.

Aedeagus asymmetric; small; apical lobe smoothly curved; evenly convergent to acute apex; few sensillae at inner edge of apical lobe.

Etymology: The specific name digitatus derived from the same Latin name meaning with fingers and refers to the large digits in the apical part of the protibia.

\section{Osoriellus germanus (SHARP, 1887) new combination} (Figs 110A-C, 124B)

Osorius germanus SHARP, 1887: 680

Type material examined: Guatemala: Capetillo, 1 female, leg. Champion (holotype in BMNH).

Further material examined: Mexico: Oaxaca, San Felipe, Mt. Mex. (96² $\left.46^{\prime} \mathrm{W}, 18^{\circ} 09^{\prime} \mathrm{N}\right)$, female, 16.-17.9.1947, leg. B. Malkin (AMNH); Oaxaca, Oaxaca City, stream bank in tropical forest (partly sifting), male, 20.11.1989, leg. 
R. Baranowski (SMNH); Mexico, without further data (NHMP); Nuevo Leon, $37 \mathrm{~km} \mathrm{SW} \mathrm{Linares,} 4.8 \mathrm{~km} \mathrm{~S}$ on Busque Escuela Rd $\left(99^{\circ} 54^{\prime} \mathrm{W}, 24^{\circ} 42^{\prime} \mathrm{N}\right), 1300 \mathrm{~m}$ elevation, under stones/leaves, 3 specimens, 21.3.1991, leg. R. Brooks, R. Leschen (KNHM, UIC); Chiapas, Mpio, San Christobal de las Casas, Reserva Huitepec $\left(92^{\circ} 40.96^{\prime} \mathrm{W}\right.$, $\left.16^{\circ} 45.09^{\prime} \mathrm{N}\right), 2450 \mathrm{~m}$ elevation, lower cloud forest litter, 1 specimen, 13.11.2001, leg. R. Anderson (KNHM).

Diagnosis: O. germanus resembles the complex of similar species of the South Mexican-Guatemalan region, i.e. O.mexicanus, O.brevipennis, and O.cordovensis. However, it is conspicuously larger than these species. Additionally, it differs from $O$. brevipennis by the absence of microsculpture on the head. The species resembles, in particular, O. mexicanus in punctation and polished surface of the head, but O. mexicanus has no protibial digits. In contrast to $O$. mexicanus, the pronotal anterior angles are produced to long teeth.

Description: Length: $6.8 \mathrm{~mm}$. Colouration: Black; legs and antennae reddish.

Head: $0.80 \mathrm{~mm}$ long, $1.30 \mathrm{~mm}$ wide; eyes slightly prominent; nearly as long as temples; angles of clypeus with granules; setiferous punctures moderately large and dense; large area at base of antennae impunctate; on average, interstices between punctures as wide as diameter of punctures; close to neck punctation denser; punctation on temples and on supraocular area very dense, granulate and partly coriaceous; isodiametric microsculpture extremely weak; surface on disc nearly polished; laterally matt due to dense coriaceous punctation.

Antennae with second antennomere slightly longer than wide; third antennomere not longer than second, but conical; antennomeres 4 to 6 slightly smaller than preceding antennomeres, but quadrate; following 4 antennomeres wider and approximately quadrate.

Pronotum: $1.25 \mathrm{~mm}$ long, $1.45 \mathrm{~mm}$ wide; widest at anterior angles; evenly convergent to obtuse posterior angles; lateral and posterior margin fine; punctation distinct and as fine and sparse as on vertex of head; interstices between punctures at least as wide as diameter of punctures; irregular midline impunctate; between coarser punctures with extreme sparse micro-punctation; surface without microsculpture and polished.

Elytra: $1.55 \mathrm{~m}$ long, $1.50 \mathrm{~mm}$ wide; setiferous punctation coarse; much denser and deeper than on pronotum; with fine coriaceous ground-sculpture; surface shiny, but less shiny than pronotum.

Abdomen with dense setiferous punctation; midline impunctate; surface with netlike microsculpture; slightly shiny; in particular, on anterior tergites; two posterior tergites with less dense microsculpture and shinier than anterior tergites.

Protibia: $0.85 \mathrm{~mm}$ long, $0.31 \mathrm{~mm}$ wide; thick; nearly semi-circular; 8 spines on outer edge; apical 3 spines on long digits; WLR: 0.50; in posterior aspect, comb at inner emargination covered in apical half; posterior face sparsely covered by yellow setae.

Aedeagus angulate in nearly rectangular angle; apical lobe very slender; ending in acute apex; at inner edge of apical lobe with row of 9 sensillae.

\section{Osoriellus infuscatus n. sp (Figs 120A-C, 124F)}

Type material: Holotype, male: Peru: Tambopata Prov. Madre de Dios Depto., $15 \mathrm{~km}$ NE Puerto Maldonado,

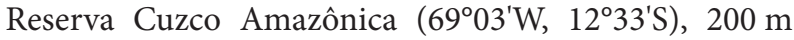
elevation, collected by flight intercept trap at Plot \#Z1U16, 22.7.1989, leg. R.A. Leschen (KNHM).

Paratypes: Peru: Pasco Dept., Villa Rica Rd. $\left(75^{\circ} 18.54^{\prime} \mathrm{W}\right.$, $10^{\circ} 47.06$ 'S), 1475 m elevation, collected by flight intercept trap, male, 15.-18.10.1999, leg. R. Brooks \& D. Brzoska (UIC); Junin Dept, La Merced, $9.5 \mathrm{~km}$ NE La MercedVilla Rica Rd. ( $\left.75^{\circ} 18.18^{\prime} \mathrm{W}, 10^{\circ} 58.42^{\prime} \mathrm{S}\right), 880 \mathrm{~m}$ elevation, collected by flight intercept trap, female, 15.-21.10.1999, leg. R. Brooks (KNHM).

Diagnosis: From the similarly sized species, O. infuscatus can be differentiated by the digitate protibia and the weak pronotal microsculpture. It highly resembles O. lescheni and $O$. loret $i$ and can be differentiated from $O$. loret $i$ by the rounded shoulders and from $O$. lescheni by the pronotal microsculpture.

Description: Length: $4.0 \mathrm{~mm}$. Colouration: Dark brown; posterior margin of pronotum and elytra lighter red with posterior margin darkend; abdomen and antennae light red; legs light brown.

Head: $0.56 \mathrm{~mm}$ long, $0.87 \mathrm{~mm}$ wide; eyes slightly prominent; nearly twice as long as temples; sides of fore-head convergent to anterior angles in slight sinuate curve; anterior edge even; setiferous punctation large but not deep and moderately sparse; supraocular area and neck with denser nearly coriacous punctation; wide midline on vertex, clypeus and area at base of antennae impunctate; on vertex interstices between punctures approximately as wide as diameter of punctures; on average, yellow setae slightly longer than interstices between punctures; without or extreme weak microsculpture; surface nearly polished. Antennae slightly shorter than head and half of pronotum combined; second antennomere oval and slightly wider than conical third antennomere; width of following antennomeres increasing, but all antennomeres nearly quadrate.

Pronotum: $0.82 \mathrm{~mm}$ long, $0.93 \mathrm{~mm}$ wide; widest at anterior angles; anterior angles nearly rectangular; evenly convergent to posterior angels; anterior edge only 1.1 times as wide as posterior edge; posterior angles obtusely rounded; in dorsal aspect, lateral margin visible throughout its total length; very slightly widened close to posterior angles; setiferous punctation moderately deep and dense; wide midline impunctate; punctures in irregu- 
lar rows; on average, interstices between punctures of row as wide as diameter of punctures; interstices between rows nearly twice as wide as diameter of punctures; between normal coarse punctures with dense micro-punctation; without microsculpture; surface nearly polished.

Elytra: $0.97 \mathrm{~mm}$ long, $0.93 \mathrm{~mm}$ wide; sides nearly parallel; shoulders nearly rectangular; setiferous punctation as deep and large as on pronotum; punctures in irregular rows; coriaceous ground-sculpture weak.

Abdomen with setiferous punctation weak and sparse; without microsculpture; surface shiny.

Protibia: $0.47 \mathrm{~mm}$ long, $0.15 \mathrm{~mm}$ wide; with 7 spines on outer edge; apical spines on short digits; WLR: 0.83; in posterior aspect, inner emargination with comb visible throughout its total length; posterior face sparsely covered by long yellow setae.

Aedeagus with apical lobe not longer than basal lobe; apical lobe moderately narrow and nearly straight; upper edge slightly curved; shortly in front of apex abruptly narrowed to obtuse apex; inner edge with sparse row of sensillae.

Etymology: The specific name infuscatus derived from the same Latin word meaning brownish and refers to the colouration of the species.

\section{Osoriellus lescheni $\mathrm{n}$. sp.}

(Figs 115A-C, 125B)

Type material: Holotype, male: Peru: Dept. Loreto, $1.5 \mathrm{~km} \mathrm{~N}$ Tienente Lopez $\left(76^{\circ} 06.92^{\prime} \mathrm{W}, 2^{\circ} 35.66^{\prime} \mathrm{S}\right)$, 210-240 m elevation, near Ganoderma, 21.7.1993, leg. R. Leschen (KNHM).

Paratypes: Peru: 2 males, 3 females with same data as holotype (KNHM, UIC).

Diagnosis: Among the species with long digits at outer edge of the protibia, O. lescheni is characterised by the light brown colouration and the polished surface. In particular, the shape of the aedeagus of O.lescheni is unique among the Neotropical Osoriellus species. The narrow apical lobe forming an acute angle to basal lobe was found in no other Neotropical species.

Description: Length: 4.6. Colouration: Dark brown; elytra dark reddish brown; posterior edge of pronotum and abdomen lighter, reddish; legs and antennae yellowish brown.

Head: $0.62 \mathrm{~mm}$ long, $0.92 \mathrm{~mm}$ wide; eyes not prominent; slightly longer than temples; sides of fore-head convergent to anterior angles in smooth concave curve; anterior edge of clypeus slightly sinuate; setiferous punctation moderately deep and dense; on fore-head sparser than on vertex; on supraocular area still denser; coriaceously punctate; on clypeus, at base of antennae and on transverse oval area close to neck impunctate; on vertex, interstices between punctures less than half as wide as diameter of punctures; on clypeus, yellow setae approximately as long as interstices between punctures; dense isodiamteric microsculpture irregular; on clypeus, denser than on vertex; surface matt; impuncate areas close to neck and at base of antennae polished, without microsculpture; surface shiny.

Antennae slightly longer than head; second antennomere oval and slightly thicker than shorter conical third antennomere; antennomeres 4 to 6 as wide as third antennomere, but quadrate; following antennomeres much wider than preceding antennomeres, but also approximately quadrate.

Pronotum: $0.89 \mathrm{~mm}$ long, $1.01 \mathrm{~mm}$ wide; widest in anterior third; slightly convergent to rectangular anterior angles; more strongly convergent to posterior angles in slight concave curve; posterior angles obtuse, but nearly rectangular; lateral margin finer in anterior half than in posterior half; slightly widened to posterior angles; setiferous punctation deeper, but sparser than on head; on average, interstices at least as wide as diameter of punctures; in irregular row adjacent to impunctate midline, interstices shorter; short yellow setae slightly shorter than interstices between punctures; between normal coarse punctures with sparse micro-punctation; without microsculpture; surface polished.

Elytra: $1.08 \mathrm{~mm}$ long, $1.03 \mathrm{~mm}$ wide; shoulders rounded, but nearly rectangular; sides slightly widened to posterior third; setiferous punctation approximately as dense and deep as on pronotum; in irregular rows; coriaceous ground-sculpture weak.

Abdomen with dense setiferous punctation; narrow midline on tergites impunctate; netlike microsculpture weak; surface slightly shiny.

Protibia: $0.50 \mathrm{~mm}$ long, $0.11 \mathrm{~mm}$ wide; slender, outer edge with 7 spines; apical spines inserted on long digits; WLR: 0.63; in posterior aspect, inner emargination with comb visible throughout its total length; posterior face sparsely covered by long yellow setae.

Aedeagus asymmetric; angulate; basal lobe thick; apical lobe slender and strongly curved; ending in acute apex; group of sensillae at base of apical lobe and on inner edge with numerous sensillae.

Etymology: The specific name derived from the name of the collector Richard Leschen to whom this interesting species is dedicated.

\section{Osoriellus loreti n. sp}

(Figs 116A-C, 125C)

Type material: Holotype, male: Peru: Dept. Loreto, $1.5 \mathrm{~km}$ Teniente Lopez, $\left(76^{\circ} 06.92^{\prime} \mathrm{W}, 2^{\circ} 36.66^{\prime} \mathrm{S}\right), 210-240 \mathrm{~m}$ elevation, collected from palmfruit by berlese method, 17.7.1993, leg. R. Leschen (KNHM).

Paratypes: Peru: 4 females, 3 males with same data as holotype (KNHM, UIC); 1 female from same location, but collected by berlese method at ridge top on 
21.7.1993; Peru, Dept. Loreto, Campamento San Jacinto

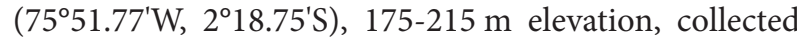
from flower fall by berlese method, 4 females, 2.7. and 10.7.1993, leg. R. Leschen (KNHM); 1 female from same location, but collected by berlese method at Qd. 22 on 2.7.1993 (KNHM).

Diagnosis: Among the species with long digits at the outer edge of the protibia, O. loreti resembles O. lescheni in the size and shape of the pronotum. It is differentiated from that species by the weak pronotal microsculpture, the rectangular shoulders and the less long digits of the protibia. Furthermore, the shapes of the aedeagi are conspicuously different between the two species.

Description: Length: $4.2 \mathrm{~mm}$. Colouration: Dark brown; elytra and posterior margin of pronotum lighter reddish brown; abdomen, legs and antennae still lighter yellowish brown.

Head: $0.52 \mathrm{~mm}$ long, $0.76 \mathrm{~mm}$ wide; eyes not prominent; as long as temples; sides of fore-head convergent to slightly prominent anterior angles in smooth concave curve; anterior edge very slightly sinuate; setiferous punctation weak and moderately dense; punctures at least partly granulate; narrow midline and small area at base of antennae impunctate; interstices between punctures at least twice as wide as diameter of punctures; yellow setae mostly shorter than interstices between punctures; few setae on supraocular area longer; isodiametric microsculpture extremely dense and deep; surface matt with iridescent shiny.

Antennae as long as head and half of pronotum combined; second antennomere oval and slightly longer than short conical third antennomere; antennomeres 4 to 6 approximately as wide as third, but quadrate; following antennomeres distinctly wider, but also approximately quadrate.

Pronotum: $0.80 \mathrm{~mm}$ long, $0.91 \mathrm{~mm}$ wide; widest in anterior third; slightly convergent to rectangular anterior angles; slightly more strongly convergent to posterior angles in smooth concave curve; posterior angles rounded, but nearly rectangular; posterior margin slightly emarginate; lateral margin thick; slightly widened to posterior angles; in dorsal aspect, visible throughout its total length; setiferous punctation much deeper and larger than on head; on average, interstices between punctures twice as wide as diameter of punctures; yellow setae nearly as long as interstices between punctures; between coarse punctures with sparse micro-punctation; impunctate midline wider in posterior half than in anterior half; isodiametric microsculpture much weaker and wider than on head; surface slightly shiny.

Elytra: $0.94 \mathrm{~mm}$ long, $0.87 \mathrm{~mm}$ wide; shoulders nearly rectangular; sides parallel; setiferous punctation as deep and dense as on pronotum; in irregular rows; coriaceous ground-sculpture deep; surface less shiny than on pronotum.
Abdomen with setiferous punctation weaker but much denser than on pronotum; netlike microsculpture weak; surface shiny.

Protibia: $0.43 \mathrm{~mm}$ long, $0.13 \mathrm{~mm}$ wide; on outer edge with 7 spines; apical spines inserted on moderately long digits; WLR: 1.00; in posterior aspect, inner emargination with comb visible throughout its total length; posterior face sparsely covered by long yellow setae.

Aedeagus symmetric with thick basal lobe and thin and slender apical lobe; in lateral aspect, apical lobe narrowed to acute apex in long smooth curve; apical lobe with lateral row of sensillae and group of three sensillae at base; inner edge of apical lobe with numerous sensillae.

Etymology: The specific name derived from the Peruvian Departamento Loreto, where the species was found.

\section{Osoriellus neotropicus (BERNHAUER, 1908) new combination \\ (Figs 113A-C, 124C)}

Osorius neotropicus BernhaUer, 1908, 295

Osorius lynchi BeRnHAUER, 1933: 333 new synonymy

Type material examined: Brazil: Rio Grande do Sul, male, without any further data (holotype of O. neotropicus in FMNH); Argentina: Buenos Aires, male, 189? (year can not be definitely recognised), leg. C. Bruch (holotype of O. lynchi in FMNH).

Further material examined: Brazil: São Paulo, male without further data, leg. J. Mráz (NHMP); Prov. Santa Fé, Chaco, 2 males, 2 females, 190?, leg. C. Bruch (NHMP); Paraguay: Itapua, San Pedro Mi, 90 m elevation, San Rafael Reserve $\left(55^{\circ} 48.18^{\prime} \mathrm{W}, 26^{\circ} 02.24^{\prime} \mathrm{S}\right)$, male, 28.11.2000, Z.H. Falin, \#PAR1F00063 (KNHM).

Diagnosis: The species is similar to O. sexpunctatus of the same region, but $O$. neotropicus is distinctly smaller. It can be additionally distinguished from that species by the shorter lateral teeth at the anterior angles of the pronotum and, in particular, by the deeper and denser punctation and the weaker microsculpture. Bernhauer (1933) differentiated also O. lynchi based on a weaker microsculpture of the pronotum and red elytra. However, I cannot find any difference in the microsculpture and the red elytra can be referred to the damaged status of the O. lynchi holotype. The aedeagi are also identical in the two male type specimens.

Description: Length: $5.9 \mathrm{~mm}$. Colouration: Black; legs and antennae reddish.

Head: $1.00 \mathrm{~mm}$ long, $1.25 \mathrm{~mm}$ wide; angles of clypeus granulate; anterior edge widely emarginate; distinctly and moderately densely punctuate; interstices between setiferous punctures as wide as or slightly wider than diameter of punctures; short yellow setae pointing diag- 
onally posteriad; wide midline impunctate; several long supraocular setae; microsculpture isodiametric; surface slightly shiny.

Antennae with first antennomere as long as following 3 antennomeres, second antennomere oval and as long as conical third, antennomeres 4 to 6 approximately quadrate; following 4 antennomeres much thicker and wider than long.

Pronotum: $1.25 \mathrm{~mm}$ long, $1.35 \mathrm{~mm}$ wide; widest at anterior angles; evenly convergent to posterior angles; anterior angles slightly produced to short teeth; posterior angles obtuse; lateral and posterior margin narrow; punctures deep and large; interstices between setiferous punctures irregular; on average, as wide as diameter of punctures; irregular row of 7 to 8 punctures along wide impunctate midline; short yellow setae pointing posteriad; netlike microsculpture; surface slightly shiny.

Elytra: $1.30 \mathrm{~mm}$ long, $1.30 \mathrm{~mm}$ wide; with coriaceous ground-sculpture; setiferous punctures as deep and dense as on pronotum; short yellow setae pointing posteriad.

Abdomen with dense setiferous punctation; setae pointing diagonally posteriad.

Protibia: $0.62 \mathrm{~mm}$ long, $0.21 \mathrm{~mm}$ wide; with 7 spines on outer edge; apical three spines inserted on moderately long digits; WLR: 0.87 ; in posterior aspect, comb of inner emargination distinctly visible throughout its total length.

Aedeagus slender; with slightly curved apical lobe; apex narrow, but obtuse; inner edge of apical lobe with row of several sensillae.

\section{Osoriellus notmani (DARLINGTON, 1937) new combination \\ (Figs 111A-C, 123D)}

Osorius notmani DARLINGTON, 1937: 297

Osorius notmani BLACKWELDER, 1943: 194

Type material examined: Jamaica: Blue Mountain Peak (holotype in MZC).

Further material examined: St. Lucia: Micoud Mahut Quilesse Reserve $\left(60^{\circ} 56^{\prime} \mathrm{W}, 13^{\circ} 50^{\prime} \mathrm{N}\right)$, male, 17.07.1980, leg. L.S. Mahunka, \#68 (NHMH).

Diagnosis: Concerning the pair of long clypeal teeth, $O$. notmani resembles $O$. bovis and $O$. cornutus. O. notmani is much larger than these two species that range between 4.5 and $4.9 \mathrm{~mm}$ length. In contrast to these species, the microsculpture of the head and the pronotum is weak, whereas at least the microsculpture of the head of O. bovis and $O$. cornutus is deep. In contrast to the species of similar size, O. notmani is light reddish brown and not dark brown or black.

Description: Length: 5.9 long. Colouration: Light brown; elytra lighter reddish; legs and antennae red.
Head: $0.80 \mathrm{~mm}$ long, $1.25 \mathrm{~mm}$ wide; eyes small; not prominent; temples 1.5 times as long as eyes; sides of fore-head evenly converegnt to anterior angles of clypeus; anterior angles of clypeus produced to acute teeth; lateral teeth one-forth as long as width between them; clypeus between acute teeth emarginate; on vertex, setiferous punctures denser than on fore-head; wide midline and area at base of antennae impunctate; on fore-head, interstices between punctures as wide as diameter of punctures; near neck, interstices between punctures half as wide as diameter of punctures; netlike microsculpture weak; surface slightly shiny.

Antennae slightly longer than head; first antennomere as long as antennomeres 2 to 4; second antennomere oval; third conical; both antennomeres equally long; following antennomeres approximately quadrate; antennomeres 6 to 10 slightly wider than preceding antennomeres.

Pronotum: $1.16 \mathrm{~mm}$ long, $1.34 \mathrm{~mm}$ wide; widest at acutely produced anterior angles; slightly narrowed posteriad to widely rounded posterior angles; lateral margin fine; in dorsal aspect, shortly in front of anterior angles invisible; setiferous punctures large and in irregular rows; punctation irregularly dense; on average, interstices as wide as diameter of punctures or slightly wider; wide midline impunctate; with sparse micro-punctation between normal setiferous punctures; netlike microsculpture weak; surface shiny.

Elytra: $1.16 \mathrm{~mm}$ long; $1.25 \mathrm{~mm}$ wide; with coarse coriaceous ground-sculpture; rows of setiferous punctures weaker than on head and pronotum; surface less shiny than on pronotum.

Abdomen with dense setiferous punctation except impunctate midline.

Protibia: $0.71 \mathrm{~mm}$ long, $0.23 \mathrm{~mm}$ wide; with 9 spines on outer edge; 3 apical spines inserted on long digits; WLR: 0.76; in posterior aspect, comb at inner edge shortly covered in middle; anterior face with few setae at apex; posterior face sparsely covered by yellow setae.

Aedeagus angulate in nearly rectangular angle; apical lobe long and at inner edge with triangular prominence; one sensilla at base of prominence; six sensillae apically to prominence.

\section{Osoriellus opacinotus $\mathrm{n}$. sp. (Figs 112A-C, 124E)}

Type material: Holotype, male: Panama: Chiriqui Prov., La Fortuna, Cont. Divide Trail $\left(08^{\circ} 46^{\prime} \mathrm{N}, 82^{\circ} 12^{\prime} \mathrm{W}\right)$, 1150 m elevation, 23.5.-9.6.1995, collected by flight intercept trap, \#155, leg. J. Ashe \& R. Brooks (KMNH).

Paratypes: Panama: 3 females, 1 male with same data as holotype (KMNH); Chiriqui Prov., NW of Volcán $\left(82^{\circ} 40.26^{\prime} \mathrm{W}, 8^{\circ} 49.16^{\prime} \mathrm{N}\right), 1400 \mathrm{~m}$ elevation, litter near stream, 17.5.2001, leg. L. Herman \& W. Opitz (AMNH); Costa Rica: San José Prov. 2.4 km ENE San Gerardo de Rivas, Cloudebridge Reserve, House Environs. $\left(09^{\circ} 28.36^{\prime} \mathrm{N}, \quad 83^{\circ} 34.51^{\prime} \mathrm{W}\right), 1700 \mathrm{~m}$ elevation, male, 
female, 8.-11.6.2004, leg. J.S. Ashe, Z. Falin, I. Hinojosa, collected by flight intercept trap (KMNH); Cartago Prov., Ref. Nac. de Fauna Silvestre Tapanti, $2.5 \mathrm{~km}$ E Station $\left(9^{\circ} 44.23^{\prime} \mathrm{N}, 83^{\circ} 46.82^{\prime} \mathrm{N}\right), 1330$ m elevation, female, 30.10 1.11.2001, collected by flight intercept trap, leg. R. Brooks (UIC).

Diagnosis: The species shows a high variability concerning the shape and microsculpture of the pronotum. The acute prominent anterior angles range from very short to extremely long. In the last case, the anterior edge of the pronotum seems to be distinctly emarginate. The microsculpture also varies from deep netlike or isodiametric with matt surface to weak netlike with micro-punctation between the normally setiferous punctation and slightly shiny surface. The species resembles $O$. schwarzi in size and microsculpture of the pronotum, but O. schwarzi shows only a slight variability in the microsculpture and has no digitate protibia. The shape of the pronotum slightly differs from O. schwarzi. In O. opacinotus, the sides are evenly convergent to posterior angles, whereas in O. schwarzi the curve of sides is more convex. In particular, the posterior angles of $O$. schwarzi are evenly rounded, whereas in O. opacinotus the pronotal shape is trapezoidal.

Description: Length: $6.8 \mathrm{~mm}$. Colouration: Dark brown; elytra brown, legs and antennae lighter brown.

Head: $1.03 \mathrm{~mm}$ long, $1.29 \mathrm{~mm}$ wide; eyes slightly prominent; as long as temples; sides of fore-head convergent to anterior angles in concave curve; anterior edge of clypeus even with angles produced to short granules; setiferous punctation on vertex weak and sparse; on supraocular area denser; isodiametric microsculpture dense and deep; surface matt.

Antennae long and slender; second and third antennomeres nearly twice as long as wide and nearly twice as long as fourth antennomere; fourth antennomere as wide as preceding antennomeres; following antennomeres increasing in width, but all approximately quadrate.

Pronotum: $1.28 \mathrm{~mm}$ long, $1.47 \mathrm{~mm}$ wide; widest at anterior angles; evenly convergent to posterior angles; posterior angles rounded; lateral margin fine; in dorsal aspect, visible in its total length; setiferous punctation moderately sparse; punctures slightly larger than on head; wide midline impunctate; interstices between punctures irregular; on average, as wide as diameter of punctures; between irregular rows, interstices between punctures wider than diameter of punctures and few areas impunctate; isodiametric microsculpture dense and deep; surface matt.

Elytra: $1.47 \mathrm{~mm}$ long; 1.47 wide; with weak coriaceous ground-sculpture and weak punctation; punctures in irregular rows and only slightly visible in ground-sculpture.

Abdomen with netlike microsculpture and dense setiferous punctation; surface matt.
Protibia: $0.74 \mathrm{~mm}$ long, $0.22 \mathrm{~mm}$ wide; semicircular; with 10 spines on outer edge; apical spines inserted on long digits; WLR: 0.62; in posterior aspect, inner emargination with comb partly covered; posterior face sparsely covered with yellow setae.

Aedeagus with long slender apical lobe ending in acute apex.

Etymology: The specific name is a combination of the Latin words opacus meaning matt and notum meaning the pronotum and refers to the matt surface of the pronotum.

\section{Osoriellus opticus n. sp.}

(Figs 118A-C, 125D)

Type material: Holotype, male: Bolivia: Santa Cruz Dept, $3.7 \mathrm{~km}$ SSE Buena Vista, Hotel Flora y Fauna $\left(63^{\circ} 33.15^{\prime} \mathrm{W}, 17^{\circ} 29.95^{\prime} \mathrm{S}\right), 400-450 \mathrm{~m}$ elevation, primary foest, collected by flight intercept trap, male, 3.-9.11.2002, leg. R. Leschen, \#BOL1L02-052 (KNHM).

Paratypes: Bolivia: 5 males, 1 female with same data as holotype (KNHM, UIC); Cochabamba, Cochabamba, $67.5 \mathrm{~km}$ NE Est. Biol. Valle del Sajita, Univ. de San Simon $\left(64^{\circ} 47.52^{\prime} \mathrm{W}, 17^{\circ} 06.33^{\prime} \mathrm{S}\right), 300 \mathrm{~m}$ elevation, collected by flight intercept trap, male, 7.-9.2.1999, leg. Genier (KNHM); Peru: Madre de Dios, Pentiacolla Lodge, $5.5 \mathrm{~km}$ NW El Mirador Trail, Alto Madre de Dios River $\left(71^{\circ} 15.28^{\prime} \mathrm{W}, 12^{\circ} 30.10^{\prime} \mathrm{S}\right), 500 \mathrm{~m}$ elevation, collected by flight intercept trap, male, 23.-26.10.2000, leg. R. Brooks (KNHM).

Diagnosis: The species is characterised by the large and thick eyes. Similarly large eyes are found in O. ocularis and O. oculatus of the O.-ocularis-group and in O. orbiculatus of the remaining-species-group. The species of the O.-ocularis-group can be differentiated by the denticulate anterior edge of the clypeus. O. orbiculatus differs by the larger and deeper pronotal punctures from O. opticus.

Description: Length: $4.6 \mathrm{~mm}$. Colouration: Dark brown; posterior edge of pronotum, elytra and abdomen slightly lighter brown; legs and antennae light brown.

Head: $0.53 \mathrm{~mm}$ long, $1.00 \mathrm{~mm}$ wide; eyes thick; more than four times longer than temples; sides of fore-head convergent in smooth concave curve to anterior angles of clypeus; anterior edge of clypeus slightly emarginate; setiferous punctation dense and moderately deep; on vertex, partly coriaceous; moderately wide midline and small area at base of antennae impunctate; on vertex, interstices between punctures less than half as wide as diameter of punctures; yellow setae on clypeus approximately as long as interstices between punctures; on vertex, setae distinctly longer than interstices between punctures; microsculpture weak and fine; surface with iridescent shine. 
Antennae as long as head and half of pronotum combined; second antennomere oval; longer than short conical third antennomere; following antennomeres increasing in width, but all antennomeres approximately quadrate.

Pronotum: $0.92 \mathrm{~mm}$ long, $1.04 \mathrm{~mm}$ wide; widest close to anterior angles; anterior angles rectangular; sides evenly convergent to obtuse posterior angles; posterior angles rounded, but nearly rectangular; sides in front of posterior angles nearly parallel; lateral margin finer in anterior half than in posterior half; in posterior half widened; in dorsal aspect, covered close to anterior angles; setiferous punctation sparser than on head, but punctures slightly larger; on average, interstices between punctures slightly wider than diameter of punctures; in irregular row adjacent to impunctate midline, interstices partly shorter; on average, yellow setae as long as interstices between punctures; without microsculpture, but with dense micro-punctation; surface polished and shiny.

Elytra: $1.13 \mathrm{~mm}$ long, $1.12 \mathrm{~mm}$ wide; shoulders rounded; sides slightly widened posteriorly; widest in posterior third; setiferous punctation as dense and deep as on pronotum; in irregular rows; coriaceous ground-sculpture moderately deep.

Abdomen with dense setiferous punctation; narrow midline on tergites impunctate; netlike microsculpture weak; surface shiny.

Protibia: $0.62 \mathrm{~mm}$ long, $0.18 \mathrm{~mm}$ wide; 8 spines on outer edge; apical spines inserted on moderately long digits; WLR: 1.0; in posterior aspect, inner emargination with comb visible throughout its total length; posterior face sparsely covered by long yellow setae.

Aedeagus asymmetric with moderately thick and long apical lobe; apical lobe evenly narrowed to acute apex; inner edge of apical lobe with row of approximately ten sensillae.

Etymology: The specific name opticus derived from the same Latin word meaning optic and refers to the large eyes of the species.

\section{Osoriellus orbiculatus n. sp.}

(Figs 107A-C, 125E)

Type material: Holotype, male: Ecuador: Sucumbios, Sacha Lodge $\left(76^{\circ} 27.35^{\prime} \mathrm{W}, 0^{\circ} 28.14 ' \mathrm{~S}\right), 270 \mathrm{~m}$ elevation, collected by flight intercept trap, 21.-24.3.1999, leg. R. Brooks, \#ECU1B99 047 (KNHM).

Paratypes: Ecuador: Napo, Jatun Sacha Biol. Station, $21 \mathrm{~km}$ E. Puerto Napo $\left(77^{\circ} 36.85^{\prime} \mathrm{W}, 1^{\circ} 04.10^{\prime} \mathrm{S}\right)$, lowland rainforest, $400 \mathrm{~m}$ elevation, collected by flight intercept trap, 2 males, 1 female, 7.7., 18.7. \& 20.7.1994, leg. F. Génier (KNHM, UIC).

Diagnosis: Among the species with digitate protibia, the species resembles O. opticus by the large and thick eyes. The differences between these two species and to O. oculatus and O. ocularis are described under O. opticus.

Description: Length: $4.5 \mathrm{~mm}$. Colouration: Brown; head and pronotum dark brown; posterior margin and posterior third of lateral margin yellowish brown; elytra light brown with darkened posterior margin; abdomen, legs and antennae yellowish brown.

Head: $0.61 \mathrm{~mm}$ long; $0.95 \mathrm{~mm}$ wide; eyes thick and distinctly prominent; nearly four times as long as temples; sides of fore-head narrowed to anterior angles in smooth sinuate curve; anterior edge of clypeus even; setiferous punctures large, but sparse; wide midline and area at base of antennae impunctate; on average, interstices between punctures as wide as diameter of punctures; on clypeus, interstices between punctures slightly wider than on vertex; isodiameteric microsculpture moderately deep and dense; surface slightly shiny.

Antennae slightly longer than head and half of pronotum combined; oval second antennomere slightly thicker than conical third, but both antennomeres equally long; following antennomeres increasing in width, but each antennomere approximately quadrate.

Pronotum: $0.85 \mathrm{~mm}$ long, $0.98 \mathrm{~mm}$ wide; widest shortly behind anterior angles; evenly convergent to posterior angles; posterior angles obtuse and shortly rounded; lateral margin fine in anterior half; distinctly widened in posterior half; in dorsal aspect; close to anterior angles nearly totally covered; setiferous punctures large; in row adjacent to wide impunctate midline denser than posteriad; interstices between punctures in central rows as wide as diameter of punctures or shorter; on disc, interstices between punctures at least as wide as diameter of punctures or slightly wider; between normal coarse punctures with denser micro-punctation; isodiametric microsculpture weak and dense; surface slightly shiny.

Elytra: $1.11 \mathrm{~mm}$ long, $1.08 \mathrm{~mm}$ wide; shoulders widely rounded; sides widest in posterior third; deep setiferous punctation in irregular rows; coriaceous ground-sculpture deep; surface slightly shiny.

Abdomen with dense and weak setiferous punctation; wide midline impunctate; netlike microsculpture weak; surface shiny.

Protibia: $0.51 \mathrm{~mm}$ long, $0.14 \mathrm{~mm}$ wide; with 9 long spines on outer edge; apical spines inserted on long digits; WLR: 0.75 ; in posterior aspect, inner emargination with comb visible throughout its total length; posterior face sparsely covered by long yellow setae.

Aedeagus angulate in obtuse angle; basal lobe short; apical lobe nearly twice as long as basal lobe; evenly convergent to obtuse apex; inner edge of apical lobe with few sensillae; denser at base and sparser to apex.

Etymology: The specific name orbiculatus derived from the same Latin word meaning circular and refers to the prominent semi-circular eyes. 


\section{Osoriellus rectangulus $\mathrm{n}$. sp.}

(Figs 121A-C, 125F)

Type material: Holotype, male: Ecuador: Sucumbios, Sacha Lodge $\left(76^{\circ} 27.35^{\prime} \mathrm{W}, 0^{\circ} 28.14 \mathrm{~S}\right), 270 \mathrm{~m}$ elevation, collected by flight intercept trap, 21.-24.3.1999, leg. R. Brooks (KNHM).

Paratypes: Ecuador: 2 females with same data as holotype (KNHM, UIC); Napo, Jatun Sacha Biol. Station (21 km E Puerto Napo), lowland rain forest, collected by flight intercept trap, female, 15.7.1994, leg. Levy \& Génier (KNHM).

Diagnosis: The species is characterised by the rectangular posterior angles of the pronotum and the rectangular shoulders. Species with similar rectangular shoulders are found in the O.-guiananus-group that differ in the absence of the pronotal setae. In the remainingspecies-group, rectangular shoulders are also found in O. rufescens and O.loreti. O. rectangulus differs from these two species by the shape of the pronotum and the black colouration.

Description: Length: $4.5 \mathrm{~mm}$. Colouration: Black; posterior angles of pronotum, legs and antennae light bown. Head: $0.58 \mathrm{~mm}$ long, $0.86 \mathrm{~mm}$ wide; eyes slightly prominent; sligthly longer than temples; fore-head convergent to anterior angles in sinuate curve; anterior edge of clypeus even; setiferous punctation moderately deep and dense; wide midline and area at base of antennae impunctate; punctation of neck without setae and much denser; on vertex, interstices between punctures and length of yellow setae slightly longer than diameter of punctures; on supraocular area, punctation denser and with few longer setae; isodiametric microsculpture on fore-head fine and dense; surface with iridescent shine.

Antennae slightly shorter than head and half of pronotum combined; second antennomere globular and as long as conical third antennomere; following antennomere increasing in width, but each antennomere approximately quadrate.

Pronotum: $0.89 \mathrm{~mm}$ long, $0.97 \mathrm{~mm}$ wide; widest shortly behind anterior angles; anterior angles rectangular; evenly convergent to posterior angles; posterior angles rectangular; lateral margin fine in anterior half and distinctly widened in posterior half; setiferous punctation moderately dense and deep; wide midline impunctate; on average, interstices between punctures 1.5 times as wide as diameter of punctures; yellow setae distinctly shorter than interstices between punctures; between normal punctures with dense micro-punctation; without microsculpture; surface polished and shiny.

Elytra: $1.10 \mathrm{~mm}$ long, $1.02 \mathrm{~mm}$ wide; shoulders rectangular; sides approximately parallel; setiferous punctation slightly weaker than on pronotum, but as dense as on pronotum; coriaceous ground-sculpture weak; surface slightly shiny.
Abdomen with fine setiferous punctation and wide impunctate midline on tergites; netlike microsculpture weak; surface with iridescent shine.

Protibia: $0.47 \mathrm{~mm}$ long, $0.17 \mathrm{~mm}$ wide; outer edge with 9 spines; apical spines inserted on short digits; WLR: 1.0; in posterior aspect, inner emargination with comb visible throughout its total length; posterior face densely covered by long yellow setae.

Aedeagus with broad apical lobe; apical lobe longer than basal lobe; upper edge of apical lobe evenly curved to obtusely rounded apex; inner edge with sparse row of sensillae.

Etymology: The specific name rectangulus derived from the same Latin word meaning rectangular and refers to the rectangular posterior angles of the pronotum and the rectangular shoulders.

\section{Osoriellus rufescens n. sp. (Figs 122A-C, 126A)}

Type material: Holotype, male: Peru: Dept. Loreto, Campamento San Jacinto $\left(75^{\circ} 51.77^{\prime} \mathrm{W}, 2^{\circ} 18.75^{\prime} \mathrm{S}\right)$, $175-215 \mathrm{~m}$ elevation, rainforest, collected by Berlese method, 6.7.1993, leg. R. Leschen (KNHM).

Diagnosis: Among the species with digitate protibia and rectangular shoulders, the species is characterised by the presence of a pronotal setiferous punctation and the light reddish colouration. In this respect it resembles O. loreti. But it differs from O. loreti by the absence or weaker pronotal microsculpture. Furthermore, the apical lobe of the aedeagus of $O$. rufescence has an obtuse apex and the aedeagus is obtusely angulate, whereas the apex in $O$. loret $i$ is acute and the aedeagus nearly rectangularly angulate.

Description: Length: $4.3 \mathrm{~mm}$. Colouration: Light reddish brown; head and posterior margin of elytra slightly darker.

Head: $0.50 \mathrm{~mm}$ long, $0.87 \mathrm{~mm}$ wide; eyes slightly prominent; nearly 1.5 times as long as temples; sides of fore-head convergent to anterior angles in deep sinuate curve; close to anterior angles parallel; anterior edge of clypeus even; setiferous punctation sparse and moderately deep; wide midline and area at base of antennae impuncate; on vertex, interstices between punctures as wide as diameter of punctures; on supraocular area slightly denser; length of yellow setae approximately as long as interstices between punctures; isodiametric microsculpture weak; surface with iridescent shine.

Antennae nearly as long as head and half of pronotum combined; second antennomere oval; slightly longer than conical third antennomere; following antennomeres increasing in width, but all approximately quadrate.

Pronotum: $0.87 \mathrm{~mm}$ long, $1.02 \mathrm{~mm}$ wide; widest close to anterior angles; anterior angles rectangular; in ante- 
rior half, sides slightly convergent, to posterior angles; in posterior half; sides emarginate; close to posterior angles parallel; posterior angles widely rounded; posterior edge nearly as wide as anterior edge; lateral margin fine in anterior half; widened in posterior half; in dorsal aspect, covered close to anterior angles; setiferous punctation deep and moderately dense; wide midline impunctate; on average, interstices 1.5 times as wide as diameter of punctures; at midline slightly denser than laterad; yellow setae approximately as long as interstices between punctures; without microsculpture, but with dense micro-punctation; surface moderately shiny.

Elytra: $1.07 \mathrm{~mm}$ long, $1.02 \mathrm{~mm}$ wide, shoulders distinctly rectangular; even slightly produced laterad; sides parallel; setiferous punctation weaker than on pronotum and hardly visible in deep coriaceous ground-sculpture.

Abdomen with setiferous punctation dense and weak; yellow setae much longer than interstices between punctures; wide midline on tergites impunctate; without microsculpture, but with iridescent shine.

Protibia: $0.46 \mathrm{~mm}$ long, $0.11 \mathrm{~mm}$ wide; outer edge with 8 spines; apical spines inserted on moderately long digits; WLR: 0.70; in posterior aspect, comb at inner emargination visible throughout its total length; on posterior face long yellow setae in transverse rows.

Aedeagus obtusely angulate; apical lobe short and evenly curved to obtuse apex; inner edge with sparse row of sensillae.

Etymology: The specific name rufescens derived from the same Latin word meaning reddish and refers to the light reddish brown colouration.

\section{Osoriellus sexpunctatus (BernHAUER, 1912) new} combination

(Figs 113A-C, 124A)

Osorius sexpunctatus BernHAUER, 1912: 168

Type material examined: Argentina: Buenos Aires, female, leg. Richter (holotype in FMNH)

Further material examined: Argentina: La Plata, Rio Santiago, 5 specimens, 5.10.1919, leg. J. Weiser (NHMP, UIC).

Diagnosis: O. sexpunctatus is distinctly characterised by the large size and the sparse pronotal punctation. The species resembles $O$. neotropicus in the shape and punctation of the pronotum. It can be distinguished from that species by the teeth-like produced anterior angles of the pronotum, the more distinct microsculpture and the smaller eyes.

Description: Length: $7.8 \mathrm{~mm}$. Colouration: Black; elytra and legs brown.
Head: $1.30 \mathrm{~mm}$ long, $1.50 \mathrm{~mm}$ wide; eyes small, only half as long as temples; anterior angels of clypeus granulate; punctation deep, but sparse; interstices between punctures irregular; on average, twice as wide as diameter of punctures; wide midline impunctate; yellow setae pointing to middle; two long supraocular setae and several long setae closer to middle; netlike microsculpture weak; surface slightly shiny.

Antennae with first antennomere as long as following 3 antennomeres; second antennomere oval and as long as conical third; antennomeres 4 to 6 approximately quadrate; following 4 antennomeres much thicker and wider than long.

Pronotum: $1.40 \mathrm{~mm}$ long, $1.65 \mathrm{~mm}$ wide; widest at anterior edge; anterior angles produced to hook-like teeth; sides evenly convergent to posterior angles; posterior edge two-third as wide as anterior edge; lateral margin extremely fine; several long setae at anterior angles and another seta in middle; along lateral margin with row of short yellow setae; punctation sparse; along wide impunctate midline row of 6 punctures; weak microsculpture netlike; surface slightly shiny.

Elytra: $1.70 \mathrm{~mm}$ long, $1.60 \mathrm{~mm}$ wide; with deep coriaceous ground-sculpture and slightly visible large punctures; surface slightly shiny.

Abdomen more densely punctate than pronotum except on wide impunctate midline; on impunctate midline of each abdominal segment several transverse striae.

Protibia: $0.85 \mathrm{~mm}$ long, $0.27 \mathrm{~mm}$ wide; 8 spines on outer edge; apical 3 spines inserted on long digits; WLR: 0.51; in posterior aspect, comb at inner edge of emargination visible throughout its total length.

Aedeagus with broad apical lobe ending in acute apex; upper edge of apical lobe sinuate; with lateral group of sensillae and row of sensillae on inner edge of apical lobe.

\section{Osoriellus sticticus n. sp. (Figs 105A-C, 126B)}

Type material: Holotype, male: Bolivia: Cochabamba, $67.5 \mathrm{~km}$ NE Est. Biol. Valle de Sajita, Univ. de San Simon $\left(64^{\circ} 47.52^{\prime} \mathrm{W}, 17^{\circ} 06.33^{\prime} \mathrm{S}\right), 300 \mathrm{~m}$ elevation, collected by flight intercept trap, 7.-9.2.1999, leg. F. Genier (KNHM), \#1BOL1G99041.

Paratypes: Bolivia: Cochabamba, Cochabamba, $109 \mathrm{~km}$ E Yungas (Cochabamba - Villa Tunari Rd.) $\left(65^{\circ} 42.54^{\prime} \mathrm{W}\right.$, $17^{\circ} 08.52$ 'S), $1400 \mathrm{~m}$ elevation, collected by flight intercept trap, male, 8.-12.2.1999, leg. F. Genier (KNHM), \#BOL1G99060; Cochabamba, Cochabamba $109 \mathrm{~km} \mathrm{E}$ Yungas (Cochabamba - Villa Tunari Rd.) $\left(65^{\circ} 42.29^{\prime} \mathrm{W}\right.$, $\left.17^{\circ} 08.50^{\prime} \mathrm{S}\right), 1480 \mathrm{~m}$ elevation, collected by flight intercept trap, male, 1.-6.2.1999, leg. F. Genier (KNHM), \#BOL1G99027; Santa Cruz, Amboro National Park, Los Volcanes $\left(63^{\circ} 36^{\prime} \mathrm{W}, 18^{\circ} 06^{\prime} \mathrm{S}\right), 1000 \mathrm{~m}$ elevation, collected by flight interecept trap, male, 20.11.-12.12.2004, leg. H. Mendel \& M.V.L. Barcley (BMNH); Peru: Hunanuco, 
Panguana ( $\left.74^{\circ} 56^{\prime} \mathrm{W}, 9^{\circ} 37^{\prime} \mathrm{S}\right)$, rainforest, collected by pitfall trap, Aug.-Sept. 1975, male, leg. W. Hanagarth (UIC).

Diagnosis: The species is characterised by its large size, the polished surface of the pronotum and the dense pronotal micro-punctation. The lateral margin of the pronotum is evenly convergent to the posterior angles in a smooth curve. Therefore, the posterior angles are obtuse without forming distinct angles.

Description: Length: $6.4 \mathrm{~mm}$. Colouration: Black; legs and antennae brown.

Head: $0.92 \mathrm{~mm}$ long, $1.35 \mathrm{~mm}$ wide; eyes slightly prominent, longer than temples; fore-head convergent to anterior edge of clypeus in slight and even concave curve; sides close to anterior angles of clypeus parallel; anterior angles of clypeus shortly produced to acute teeth; anterior edge between teeth even; setiferous punctation irregular; on clypeus slightly sparser than on vertex; large transverse oval area on vertex and area at base of antennae impunctate; short midline on anterior vertex impunctate; setae moderately long; lateral punctures of vertex and on supraocular area granulate; netlike microsculpture distinct; surface moderately matt.

Antennae slightly longer than head; second antennomere oval; slightly longer than wide; third conical and as long as second; fourth antennomere conical and as wide as third, but shorter; antennomeres 5 and 6 quadrate and as wide as preceding antennomeres; following antennomeres wider than preceding antennomeres and approximately quadrate.

Pronotum: $1.21 \mathrm{~mm}$ long, $1.40 \mathrm{~mm}$ wide; widest at obtuse anterior angles; sides evenly convergent to posterior angles; posterior angles obtuse; in front of posterior angles shortly and slightly emarginate; lateral margin fine; slightly widened in front of posterior angles; setiferous punctation deep and moderately dense; setae extremely short; shorter than diameter of punctures; on average, interstices between punctures twice as wide as diameter of punctures; line of punctures adjacent to impunctate midline denser; partly coriaceous; netlike microsculpture moderately deep; surface moderately matt.

Elytra: $1.53 \mathrm{~mm}$ long, $1.40 \mathrm{~mm}$ wide; widest in posterior third, but sides nearly parallel; setiferous punctation as deep and dense as on pronotum, but hardly visible in deep coriaceous ground-sculpture; surface matt.
Abdomen with dense setiferous punctation; setae longer than on fore-body; punctures on abdominal tergites VII and VIII partly granulate and striate.

Protibia: $0.86 \mathrm{~mm}$ long, $0.29 \mathrm{~mm}$ wide; 10 spines on outer edge; 4 apical spines inserted on moderately long digits; WLR: 0.73 ; in posterior aspect, inner emargination with comb visible throughout its total length; posterior face densely covered by long yellow setae.

Aedaegus rectangularly angulate; apical lobe long with straight inner edge; apex of apical lobe moderately acute and slightly curved; inner edge of apical lobe with numerous sensillae.

Etymology: The specific name derived from the same Latin word meaning punctate and refers to the dense punctation of the abdomen.

\section{Osoriellus trinitatis (BLACKWELDER, 1943) new combination \\ (Figs 103A-C, 123B)}

Osorius trinitatis BLACKWELDER, 1943: 199

Type material examined: Trinidad: Arima, $12 \mathrm{mi} . \mathrm{N}$, female, 23.06.1935, leg. G. Weber (paratype in NMNH).

Further material examined: Trinidad: Arima $\left(61^{\circ} 16^{\prime} \mathrm{W}\right.$, $\left.10^{\circ} 37^{\prime} \mathrm{N}\right)$, Blanchisseuse, rotten log on ground, $550 \mathrm{~m}$ elevation, male, female, 05.01.1961, leg. T. Clay (BMNH); Aripo $\left(61^{\circ} 15^{\prime} \mathrm{W}, 10^{\circ} 42^{\prime} \mathrm{N}\right) \mathrm{N}$. Range, cloud forest, debris among aerial palm roots, $920 \mathrm{~m}$ elevation, 2 females, 21.01.1961, leg. T. Clay (BMNH); Panama: La Fortuna, Continental Divide Trail $\left(82^{\circ} 12^{\prime} 0^{\prime \prime} \mathrm{W}, 8^{\circ} 46^{\prime} 0^{\prime \prime} \mathrm{N}\right)$; berlesate forest litter, $1200 \mathrm{~m}$ elevation, 2 males, 5 females, 9.6.1995, leg. R. Anderson, \#PAN2A95 10F (KNHM, UIC); Costa Rica: Heredia, $10 \mathrm{~km}$ SE La Virgen $\left(84^{\circ} 05^{\prime} \mathrm{W}\right.$, $\left.10^{\circ} 20^{\prime} \mathrm{N}\right), 450-550 \mathrm{~m}$ elevation, female, 17.-21.3.2003, leg. R. Anderson (KNHM); Heredia, La Selva, $3.2 \mathrm{~km}$ SE Puerto Viejo, $100 \mathrm{~m}$ elevation, flight intercept trap, female, 17.3.1992, leg. W. Bell (KNHM); Guanacaste, Guanacaste Conservation Area, Patilla Field Station, sampled in cloud-wet montane trans. litter, $1000 \mathrm{~m}$ elevation, 1 male, 2 females, 14.2.1996, leg. R. Anderson (KNHM, UIC); Alajuela, E.B. San Ramon, R.B. San

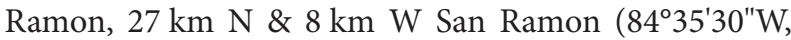
$\left.10^{\circ} 13^{\prime} 30^{\prime \prime} \mathrm{N}\right), 950 \mathrm{~m}$ elevation, female, 14.7.1997, leg.

Key to the remaining species

1. Smaller than $6.0 \mathrm{~mm}$.

Longer than $6.5 \mathrm{~mm}$.

2. Eyes thick and nearly semicircular

Eyes less thick, only slightly prominent or not prominent

3. Punctation of pronotum sparse, but punctures very large, surface with microsculpture, sides only slightly narrowed to posterior angles, lateral and posterior margin of pronotum and elytra yellowish brown. O. orbiculatus n. sp. 
Punctation of pronotum denser, punctures smaller, surface without microsculpture, sides evenly narrowed to posterior angles in smooth curve, colouration dark brown.

4. Protibia with extremely long digits, WLR smaller than 0.35 .

Protibia with moderately long digits; WLR higher than 0.60 .

5. Smaller than $4.0 \mathrm{~mm}$, anterior angles of pronotum not produced to acute teeth, posterior angles of pronotum rounded.

O. digitatus n. $\mathrm{sp}$

- Longer than $5.0 \mathrm{~mm}$, anterior angles produced to distinct acute teeth, posterior angles obtuse, but distinctly angulate.

O. acutus n. $\mathrm{sp}$.

6. At least $4.0 \mathrm{~mm}$ long.

Smaller than $3.5 \mathrm{~mm}$

7. Setiferous punctation of pronotum dense and coarse, interstices between punctures distinctly shorter than diameter of punctures.

O. carinicollis (Notman, 1925)

Setiferous punctation of pronotum sparser and finer, interstices between punctures as wide as diameter of punctures.

8. Shoulders with rectangular angle.

Shoulders rectangular, but rounded.

9. Black, sides of pronotum evenly narrowed to posterior angles.

O. rectangulus $\mathrm{n}$. $\mathrm{sp}$.

Light reddish brown, sides of pronotum slightly emarginate in middle, nearly parallel in posterior half.

10. Head with weak microsculpture, surface moderately shiny, pronotum without microsculpture or only with remains of microsculpture, surface shiny.

O. rufescens n. sp.

- Head with dense and deep microsculpture, surface matt, pronotum with dense, but weak microsculpture, surface moderatly shiny.

O. loreti n. sp.

11. At least $5.3 \mathrm{~mm}$ long.

Smaller than $4.8 \mathrm{~mm}$.

12. Pronotum with deep and dense microsculpture, surface matt.

O. adustus n. sp.

Pronotum without or with weak microsculpture, surface shiny.

13. Head with dense microsculpture, surface with iridescent shine. O. weberi (BLACKWELDER, 1943)

- Head without or with weak microsculpture, surface without iridescent shine.

14. Light brown, surface of pronotum polished and shiny.

O. lescheni n. sp.

- Dark brown, surcface of pronotum with weak microsculpture, moderately shiny.

O. infuscatus n. $\mathrm{sp}$.

15. Pronotum with dense and finer punctation, without impunctate midline. ...... O. cordovensis (BERNHAUER, 1910)

- Pronotum with sparser or coarser punctation and with wide impunctate midline.

16. Light red, angles of clypeus produced to acute teeth, punctation of pronotum sparser, interstices between punctures tree to four times as wide as diameter of punctures

O. notmani (DARLINGTON, 1937)

- Dark brown, angles of clypeus produced to granules, punctation of pronotum denser, two times as wide as diameter of punctures.

O. neotropicus (BERNHAUER, 1908)

17. Sides of pronotum strongly narrowed in distinct curve to posterior angles, pronotum with weak or without microsculpture, surface shiny or polished.

Sides evenly and straightly narrowed to posterior angles; pronotal shap trapezoidal, pronotum with dense and deep microsculpture, surface matt.

18. Anterior angles of clypeus only produced short granules, microsculpture of pronotum dense, surface matt. O. opacinotus n. sp.

Anterior angles of clypeus produced to short and acute teeth, microsculpture of pronotum less dense, surface moderately matt.

O. sticticus n. sp. 
19. Punctation of pronotum sparse, interstices between punctures at least twice as wide as diameter of punctures. .... O. sexpunctatus (BERNHAUER, 1912)

Punctation of pronotum denser, interstices between punctures as wide as diameter of punctures or slightly wider. O. germanus (SHARP, 1887)

R. Anderdson (KNHM); Peru: Loreto, Campamento San Jacinto $\left(75^{\circ} 51^{\prime} 77^{\prime \prime} \mathrm{W}, 2^{\circ} 18^{\prime} 75^{\prime \prime} \mathrm{S}\right), 175-215 \mathrm{~m}$ elevation, rainforest berlese, female, 6.7.1993, leg. R. Leschen (KNHM); Loreto, $1.5 \mathrm{~km} \mathrm{~N}$ Teniente Lopez $\left(76^{\circ} 06.92^{\prime} \mathrm{W}\right.$, $2^{\circ} 35.66^{\prime}$ S), 210-240 m elevation, nr. Ganoderma, female, 21.7.1993, leg. R. Leschen (KNHM); Bolivia: Cochabamba, $117 \mathrm{~km}$ E Yungas, Lagunitas $\left(65^{\circ} 40^{\prime} 57^{\prime \prime}\right.$, $\left.17^{\circ} 6^{\prime} 22^{\prime \prime S}\right)$, flight intercept trap, female, 1.-6.2.1999, leg. F. Genier (KNHM).

Diagnosis: Among the species with digitate protibia and setiferous pronotal punctation, the species resembles O. carinicollis in size and shape of the pronotum, but it has a distinctly finer punctate pronotum. The aedeagus is thick and obtuse at apex, whereas it is thin and acute in O. carinicollis.

Description: Length: $3.1 \mathrm{~mm}$. Colouration: Brown; pronotum and elytra at shoulders reddish; legs, antennae, and anterior margin of clypeus yellow.

Head: $0.37 \mathrm{~mm}$ long, $0.58 \mathrm{~mm}$ wide; eyes not prominent and as long as temples; sides of fore-head sinuate; anterior edge of clypeus even; without lateral granules; width of anterior edge smaller than width of head in front of eyes; on vertex, setiferous punctation dense and coarse; interstices between punctures half as wide as diameter of punctures; irregular midline impunctate; impunctate midline without microsculpture; surface polished and shiny; on punctate areas of vertex with remains of microsculpture; surface matt or slightly shiny.

Antennae short; slightly longer than head; second antennomere thick and oval; distinctly longer than conical third antennomere; following 3 antennomeres slightly increasing in width and distinctly wider than long; antennomeres 7 to 11 distinctly thicker than preceding antennomeres; antennomere 10 only slightly wider than long.

Pronotum: $0.53 \mathrm{~mm}$ long, $0.56 \mathrm{~mm}$ wide; widest at anterior angles; sides evenly convergent to posterior widely rounded angles; lateral margin fine; in dorsal aspect, visible throughout its total length; setiferous punctation distinctly finer and sparser than on head; interstices between punctures approximately as wide as diameter of punctures; between normal punctures with sparse micropunctation and weak remains of microsculpture; surface mostly polished and shiny.

Elytra: $0.68 \mathrm{~mm}$ long, $0.59 \mathrm{~mm}$ wide; ground-sculpture deep and coarse; coarse setiferous punctation nearly invisible in ground-sculpture; surface matt.

Abdomen with coarse setiferous punctation; similar to elytral punctation; surface matt, except impunctate shinier midline.
Protibia: $0.30 \mathrm{~mm}$ long, $0.10 \mathrm{~mm}$ wide; on outer edge with 8 long spines; 3 apical spines inserted on short digits; WLR: 1.00; posterior face covered with sparse setae; in posterior aspect, inner emargination distinctly visible; in middle, partly covered by posterior inner edge.

Aedeagus with thick apical lobe ending in widely rounded obtuse apex; along inner edge with groups of several sensillae.

\section{Osoriellus weberi (BLACKWELDER, 1943) new combination \\ (Figs 119A-C, 125A)}

Osorius weberi BLACKWELDER, 1943: 198

Type material examined: Trinidad: 12 miles $\mathrm{N}$ of Arima $\left(61^{\circ} 16 \mathrm{~W}, 10^{\circ} 37^{\prime} \mathrm{N}\right)$, male, 23.6.1935, leg. N.A. Weber (holotype in MCZ).

Further material examined: Brazil: Amazonas, Manaus, INPA/Smithsonian Res.2 (59 $\left.50^{\prime} \mathrm{W}, 2^{\circ} 25^{\prime} \mathrm{S}\right)$, leaf litter of terra firme forest, collected by Winkler method, 1 male, 4 females, 3.1994, 1.1994, 2.1994, leg. R. Didham (BMNH); Peru: Dept. Loreto, Campamento San Jacinto $\left(75^{\circ} 51.77^{\prime} \mathrm{W}, 2^{\circ} 18.75^{\prime} \mathrm{S}\right)$, collected by flight intercept trap, 175-215 m elevation, male 7.7.1993, leg. R. Leschen (KNHM); Huanuco, Panguana (74 $\left.56^{\prime} \mathrm{W}, 9^{\circ} 37^{\prime \prime S}\right)$, cut forest, female, 3.8.1975, leg. W. Hanagarth (UIC).

Diagnosis: The species is characterised by the iridescent shine of the head and the digitate protibia. Other species with iridescent shine are smaller and have no digitate protibia. Similarly large species with digitate protibia, e.g. O. lescheni, have no iridescent shine on the head. The thick apical lobe of the aedeagus narrowed abruptly to the acute apex. In ventral aspect, the aedeagus resembles that of $O$. lescheni and O. loreti, since the circular basal lobe is much thicker than the apical lobe. In the male specimen from Peru, the apical lobe is thicker than in the Central Amazon or Trinidad males, but this may be within the range of the species.

Description: Length: $4.5 \mathrm{~mm}$. Colouration: Dark brown; elytra lighter reddish brown; abdomen, legs and antennae still lighter yellowish brown.

Head: $0.52 \mathrm{~mm}$ long, $0.84 \mathrm{~mm}$ wide; eyes slightly prominent; nearly twice as long as temples; fore-head convergent to anterior angles in smooth concave curve; anterior edge of clypeus even; setiferous punctation weak and moderately sparse; punctures partly granulate; punc- 
tures close to neck and on supraocular area larger; yellow setae as long or slightly longer than interstices between punctures; isodiametric microsculpture weak and dense; surface with iridescent shine; on supraocular area and on lateral neck, microsculpture slightly deeper.

Antennae as long as head and half of pronotum combined; second antennomere oval and distinctly longer than wide; as long as conical third antennomere; antennomeres four to six slightly increasing in width; following antennomeres distinctly wider than preceding antennomeres, but all quadrate.

Pronotum: $0.84 \mathrm{~mm}$ long, $0.93 \mathrm{~mm}$ wide; widest close to anterior angles; sides convergent to obtuse posterior angles in even curve; posterior angles widely rounded; lateral margin distinct; in dorsal aspect, visible throughout its total length; slightly widened posteriorly; setiferous punctation larger and deeper than on head; moderately sparse; on average, interstices between punctures as wide as diameter of punctures; in irregular row adjacent to impunctate midline denser; impunctate midline in anterior half narrower than in posterior half; yellow setae as long as or slightly longer than interstices between punctures; between normal coarse punctures, with sparse micro-punctation; isodiametric microsculpture weak and less dense than on head; surface without iridescent shine; slightly shiny.

Elytra: $1.01 \mathrm{~mm}$ long, $0.95 \mathrm{~mm}$ wide; shoulders rounded; sides slightly widened to posterior third; setiferous punctation similarly dense and large as on pronotum; in irregular rows; coriaceous ground-sculpture coarse; surface less shiny than pronotum.

Abdomen with denser setiferous punctation than on forebody; yellow setae much longer than interstices between punctures; narrow midline impuncate; netlike microsculpture weak; surface shiny.

Protibia: $0.42 \mathrm{~mm}$ long, $0.13 \mathrm{~mm}$ wide; with seven spines at outer edge; apical spines inserted on long digits; WLR: 0.60; in posterior aspect, inner emargination with comb visible in its total length; posterior face sparsely covered by long yellow setae.

Aedaegus angulate in nearly rectangular angle; symmetric; with thick apical lobe; close to apex, apical lobe suddenly narrowed to acute apex; two lateral sensillae at base of apical lobe; at inner edge of apical lobe with row of sensillae close to apex and second row of four sensillae close to base.

\section{Discussion}

In the first part of the review of the Neotropical Osorius complex, the species placed in the genus Osorius Guérin-Menelville, 1829 and the new genus Antillosorius Irmler, 2010 were described (IRMLer 2010). The genus Osorius comprises all species with digitate protibia and setae and spines on its posterior face. The pronotal sides are at least slightly sinuate in front of the posterior angles and the lateral pronotal margin is widened posteriorly. The aedeagus can be symmetric or asymmetric, but has the opening in the upper centre and no spiral endophallus such as in the African genus Afrosorius FAgEL, 1958. The species of the genus Antillosorius resemble those of the genus Osorius in the structure and shape of the pronotum as well as in the absence of a spiral endophallus. However, they have the posterior face of the protibia only covered by setae without additional spines and the aedeagus is asymmetric with a lateral opening. With respect to the African species of this complex, FAGEL (1959) described the genera Osoriellus FAgEL, 1959, Osoriocanthus FAgEL, 1959 and Neosorius Fagel, 1959. The three genera were defined by the combination of the following characters: Osoriellus: shoulders of elytra not produced, outer edge of the protibia without digits and posterior face only covered by setae, and an asymmetric aedeagus with lateral opening and without spiral endophallus; Osoriocanthus: shoulders of the elytra acutely produced or at least rectangular, outer edge of the protibia digitate and posterior face covered only by setae, and a symmetric or asymmetric aedeagus, but with the opening in the upper centre and without spiral endophallus; Neosorius: with digitate protibia, posterior face of the protibia with setae and spines and a symmetric or asymmetric aedeagus, but with spiral endophallus like in the genus Afrosorius FAGEL, 1959.

In the Neotropical material of the Osorius complex only two species were found with the combination of characters defined for the genus Neosorius. These species will be described later. All other species of the neotropical fauna have no spiral endophallus and, in this respect, resemble the African species of the genera Osoriellus and Osoriocanthus. In the present paper all species are comprised that have no spines on the posterior face of the protibia, but differ in the structure and shape of the pronotum as found in the genera Osorius and Antillosorius.

It was tried to separate the species described in the present paper into different genera referring to the combination of characters found in the African species of the genera Osoriellus and Osoriocanthus. It was impossible. The Neotropical species without spines on the posterior face of the protibia show a diverse combination of characters: species without digits on the protibia, but with symmetric aedeagus, species with digits and asymmetric aedeagus, species without digits and asymmetric aedeagus, species with or without setiferous punctation and all the other combinations of characters. It was tried to find differentiating characters in the shape, number of digits or width: length ratio of the protibia (Fig. 125). All characters show high variations, but no clear generic separations.

Species with rectangular shoulders were also found that might be placed to the genus Osoriocanthus. However, rectangular shoulders are combined with a symmeteric aedeagus and central opening, i.e. in the O.-guiananusgroup, but also with asymmetric aedeagus and lateral 
opening, i.e. in the remaining-species-group. Overall, at present it was impossible to find generic differentiating characters for the species described in the present paper. Therefore, they were comprised in the genus Osoriellus. The character combination for the Neotropical species of the genus Osoriellus are the following: lateral pronotal margin fine or only slightly widened posteriorly, posterior face of the protibia covered only by setae, protibia digitate or non-digitate, aedeagus symmetric or asymmteric with lateral or central opening.

As can be derived from the large number of species, Osoriellus seems to be a very species-rich genus. Within the material studied still more species were found that were only available in female specimens that prevent a sufficient description. It can be supposed that the presently described number of species is only poor compared to the really existing number of species in the Neotropics and that it is the most species-rich genus of the subfamiliy Osoriinae in the Neotropical region. With 105 species described, the number of species is still higher than in the genus Holotrochus with 103 species.

Most specimens of the genus were collected by flight intercept traps. Thus, only little can be derived from the collecting to the ecology of the species. Compared to the most related species of the genus Osorius that are larger in size, it can be supposed that most species are living in decaying wood of trunks, branches or twigs; and the enormous number of species can be referred to the different size and age of decaying wood. As only few specimens were collected directly in decaying wood, from litter or similar substrates, it is supposed that most species of the genus live in the lower vegetation or canopy layer of the rainforests.

As for the ecology, nearly nothing can be derived from the labelled information for the geographic distribution of the species. Most species were found in very few specimens and from very few locations which, however, may be referred to the poor collecting status and not to the restricted distribution.

\section{References}

Bernhauer, M. 1904: Neue exotische Staphyliniden. - Verhandlungen der k. k. zoologisch-botanischen Gesellschaft in Wien 54: 4-24.

Bernhauer, M. 1908: Beitrag zur Staphylinidenfauna von Südamerika. - Archiv für Naturgeschichte 74: 283-372.

Bernhauer, M. 1910: Beitrag zur Kenntnis der Staphyliniden-Fauna von Zentralamerika. -Verhandlungen der k. k. zoologisch-botanische Gesellschaft Wien 60: 350-393.

Bernhauer, M. 1911: Zur Staphylinidenfauna von Südamerika (7. Beitrag). - Deutsche Entomologische Zeitschrift 1911: 403-421.
Bernhauer, M. 1912: Zur Staphylinidenfauna von Südamerika (8. Beitrag). - Entomologische Blätter 6: 167-179.

Bernhauer, M. 1920: Neue Arten der Staphylinidenfauna von Südamerika, insbesondere aus den Gattungen Osorius und Megalops. - Neue Beiträge systematische Insektenkunde 2: 9-11.

Bernhauer, M. 1933: Neue Staphyliniden aus Argentinien (I) (Col). - Revista de Entomologia 3: 326-334.

Bernhauer, M. 1934: Neue Staphyliniden (Col.) aus Südamerika. - Stylops 3: 156-162.

BLACKWELDER, R. E. 1943: Monograph of the West Indian beetles of the family Staphylinidae. - Smithsonian Institution. United States National Museum. Bulletin 182: 1-658.

DARlington, P. J. 1937: The West Indian species of Osorius (Coleoptera: Staphylinidae). - Bulletin of the Museum of Comparative Zoology 80: 283-301.

FAGEL, G. 1958: Mission de muséum dans les îles du golfe de Guinée. Entomologie. Sur quelques Osoriinae du golfe de de Guinée. - Revue Française d'Entomologie 25: 26-32.

FAGEL, G. 1959: Osoriinae (Coleoptera, Polyphaga) Fam. Staphylinidae. - In: Baert, P; Demoulin, G.; Denisoff, I.; Martin, J.; Micha, M.; Noirfalise, A.; Schoemaker, P.; Troupin, G. \& Verschuren, J. (eds.): Parc national de la Gamba. Mission H. de Saeger. Vol. 12, Brussels, Hayez: 1-205.

Fauvel, C. 1891: Voyage de M. E. Simon au Venezuela. Revue d'Entomolgie 10: 87-127.

Gravenhorst, I. L. C. 1806: Monographia Coleopterorum Micropterorum. - Dieterich, Göttingen: pp. 236.

GuÉRIN-Meneville, F. E. 1829: Iconographie de règne animal de G. Cuvier, ou représentation d'après nature de l'une des espèces les plus remarquables et souvent non encore figurées, de chaque genre d'animaux. Avec un texte descriptif mis au courant de la science. Ouvrage pouvant servir d'atlas a tous les traites de zoologie. II. Planches des animaux invertébrés. Baillière, Paris.

Hadley, A. 2006: Combine Z5.3. Public Domain software. Herman, L. 2001: Catalogue of the Staphylinidae (Insecta: Coleoptera). 1758 to the end of the second millennium. II. Oxyteline group. - Bulletin of the American Museum of Natural History 265: 1067-1806.

IRMLER, U. 2010: The Neotropical species of the genus Osorius Guérin-Meneville, 1829 with remarks to the Neotropical Osoriid complex. - Beiträge zur Entomologie 60: 363-426.

LynCH Arribálzage, F. 1884: Estafilinos de Buenos Aires. - Boletin de la Academia Nacional de Ciencias, Tom 7: 5-392.

Notman, H. 1920: Staphylinidae from Florida in the collection of the American Museum of Natural History, with description of new genera and species. - Bulletin American Museum Natural History 42: 693-732. 
Notman, H. 1925: A synoptic review of the beetles of the tribe Osoriini from the Western Hemisphere. Proceedings of U.S. National Museum 67: 1-26.

Sharp, D. 1887: Fam. Staphylinidae. - In: Biologia Centrali-Americana. Insecta, Coleoptera. Vol. 1 (2). Taylor \& Francis, London: pp. 145-824, pls. 5-19.

Sharp, D. 1876: Contributions to the Staphylinidae of the Amazon valley. - Transactions of the Entomological Society London: 34-424.

Wendeler, H. 1955: Neue Staphyliniden aus Brasilien (1. Teil). - Dusenia 6: 187-198.
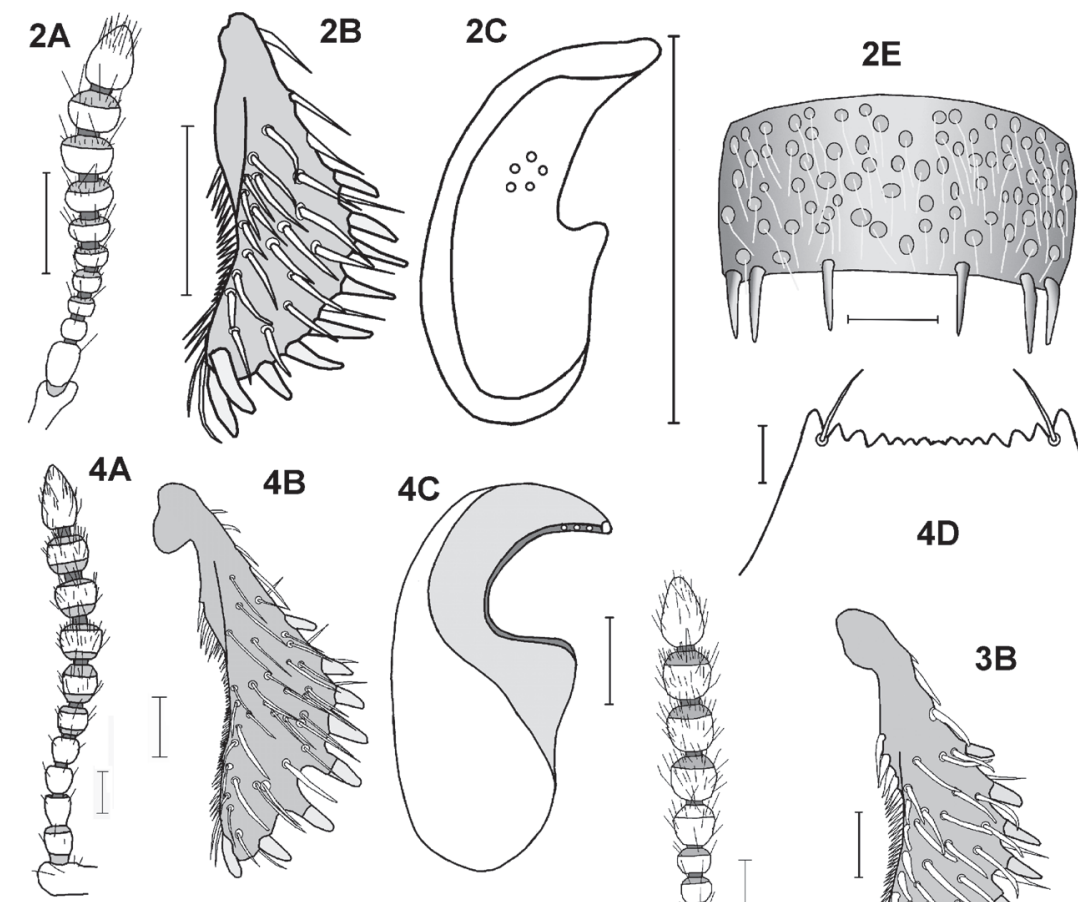

A
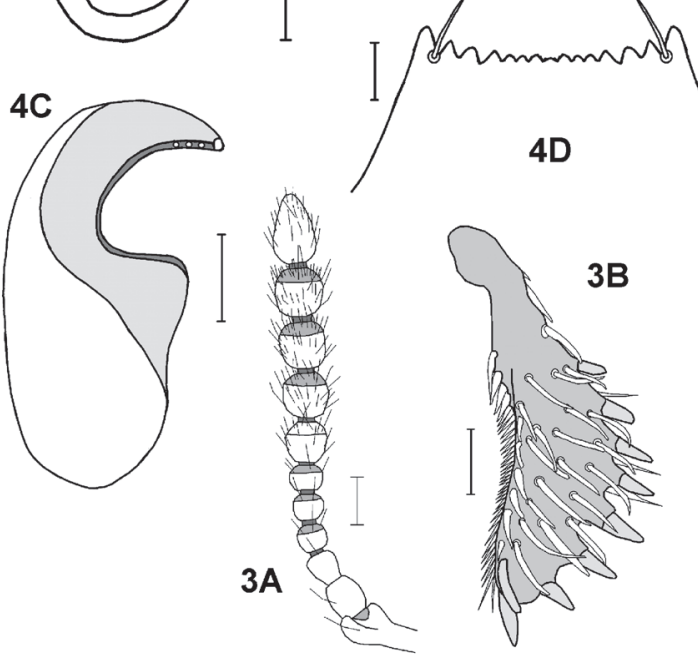

Fig. 2-4: Osoriellus-coronatus- and -laeviusculus-group: Osoriellus coronatus (2), O. laeviusculus (3), O. schubarti (4); antenna (A), protibia (B), aedeagus in lateral aspect (C), anterior edge of clypeus (D), abdominal segment VII (E); scale bar: $0.1 \mathrm{~mm}$. 

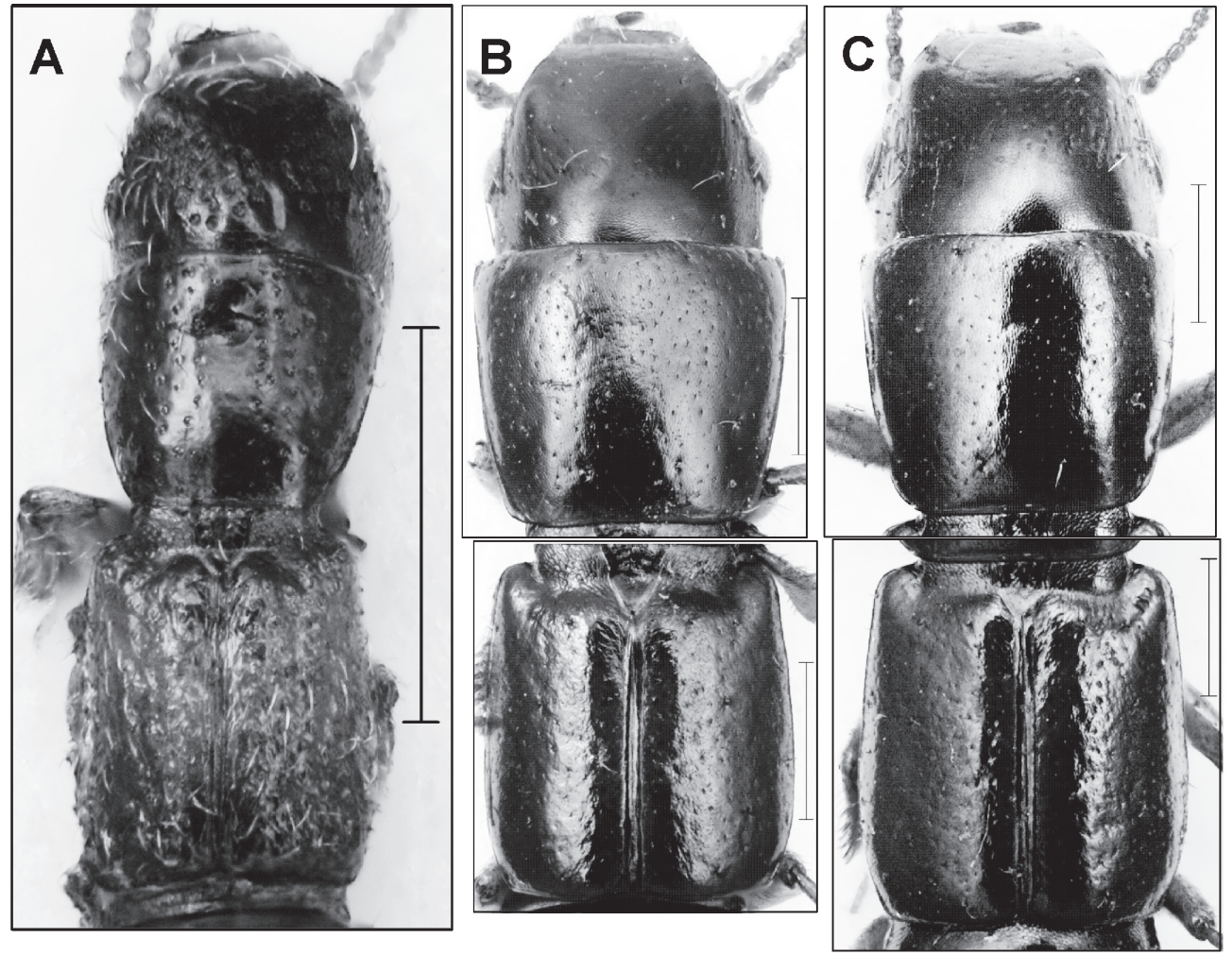

Fig. 5: Osoriellus-coronatus- and -laeviusculus-group: Head, pronotum and elytra of Osoriellus coronatus (A); O. laeviusculus (B), O. schubarti (C); scale bar: $0.5 \mathrm{~mm}$. 

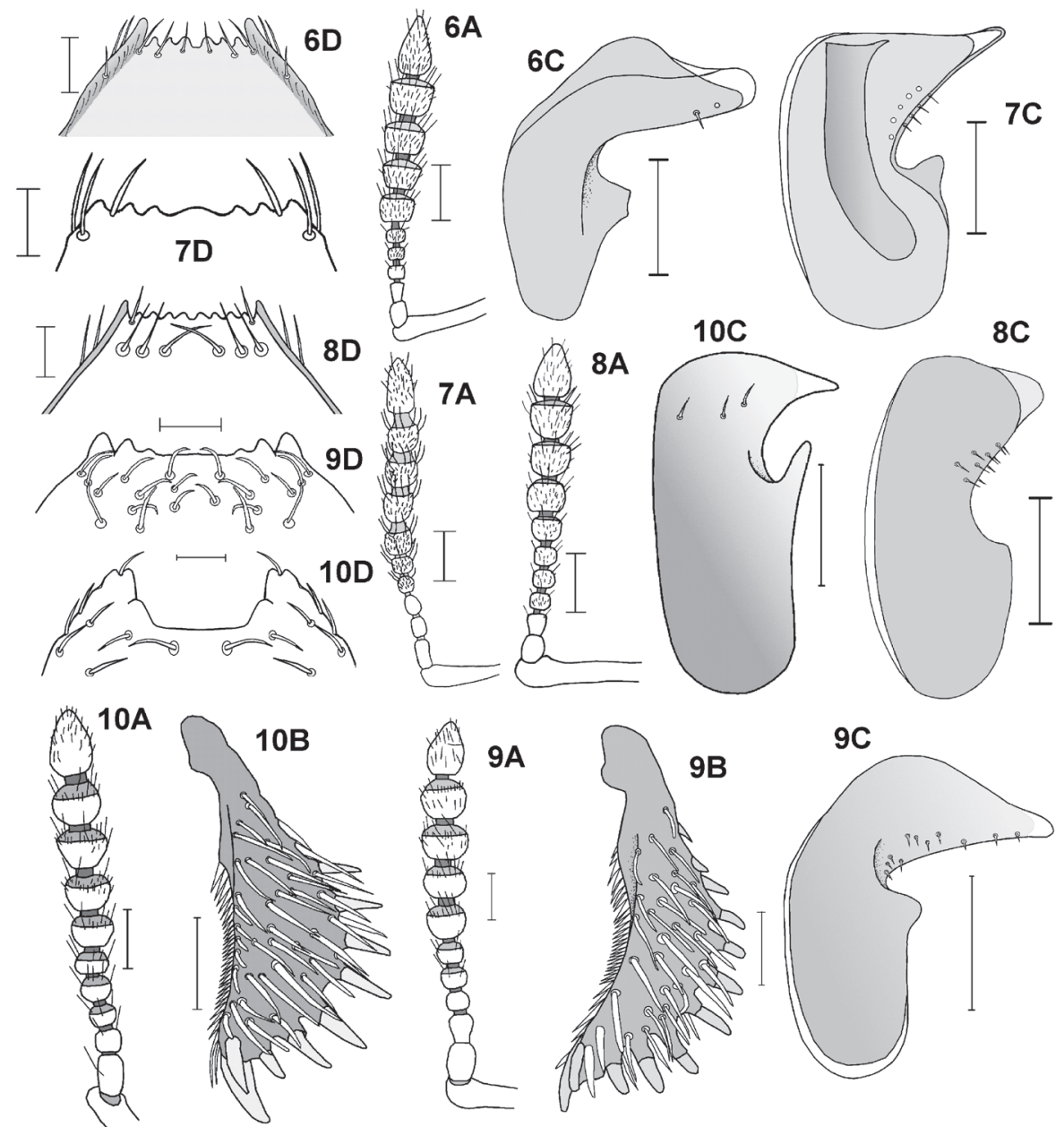

Fig. 6-10: Osoriellus-oculatus-group: Osoriellus ocularis (6), O. oculatus (7), O. hanagarthi (8) O. sexdentatus (9) O. denticornis (10); antenna (A), protibia (B), aedeagus in lateral aspect (C), anterior edge of clypeus (D); scale bar: $0.1 \mathrm{~mm}$. 

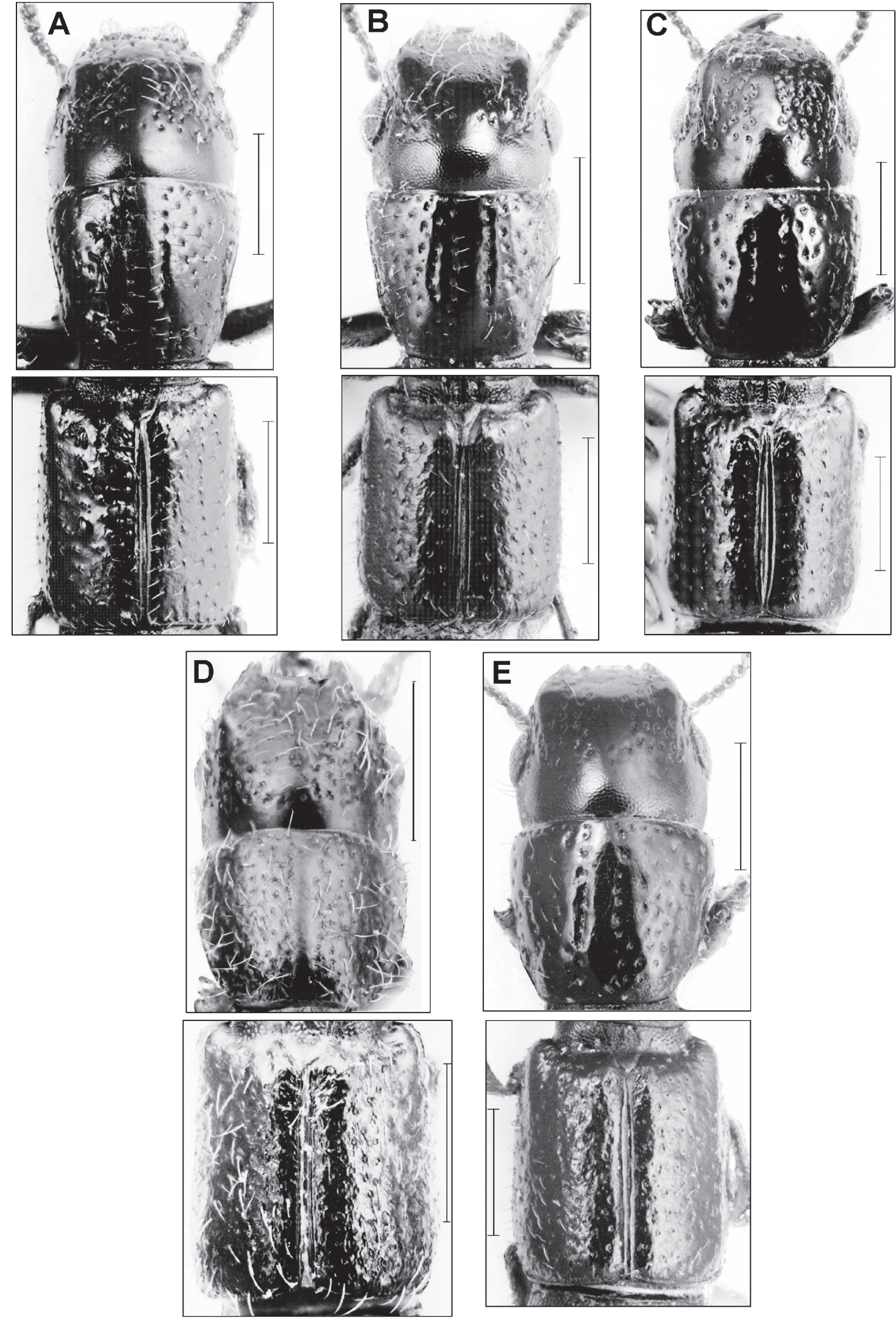

Fig. 11: Osoriellus-oculatus-group: Head, pronotum and elytra of Osoriellus hanagarthi (A), O. ocularis (B), O. oculatus (C), O. denticornis (D), O. sexdentatus (E); scale bar: $0.5 \mathrm{~mm}$. 


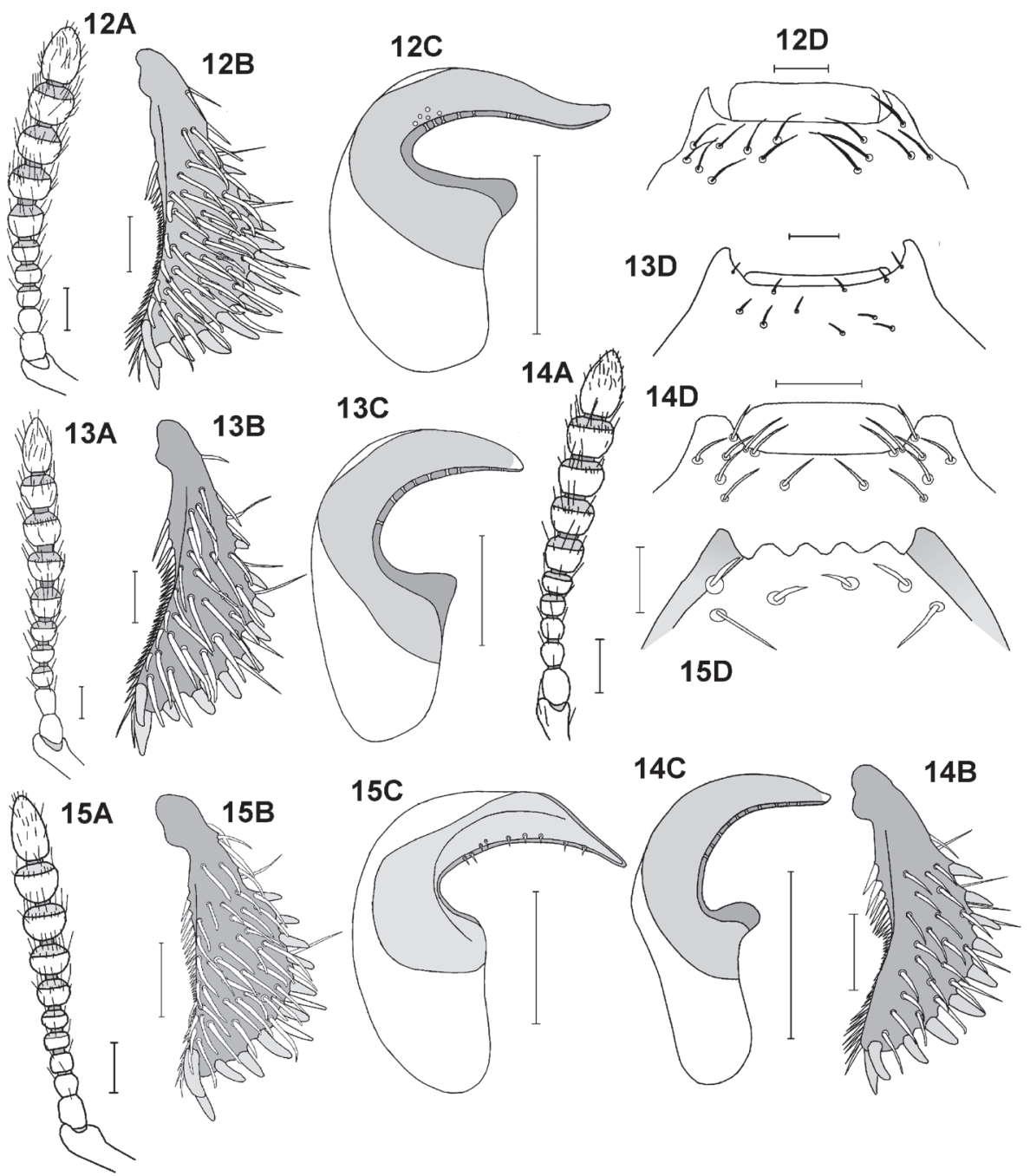

Fig. 12-15: Osoriellus-bicornis-group: Osoriellus bovis (12), O. cornutus (13), O. bicornis (14), O. spinosus (15); antenna (A), protibia (B), aedeagus in lateral aspect (C), anterior edge of clypeus (D); scale bar: $0.1 \mathrm{~mm}$. 


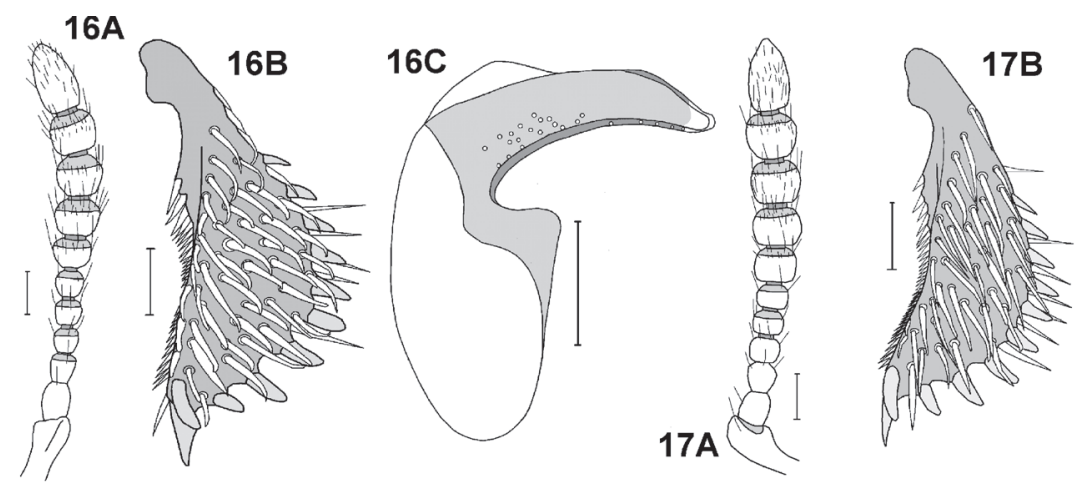

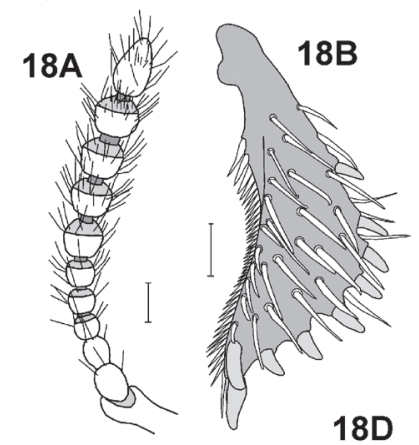

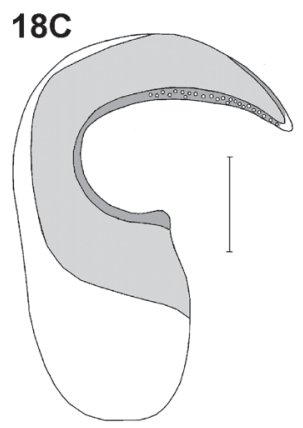

$17 \mathrm{C}$

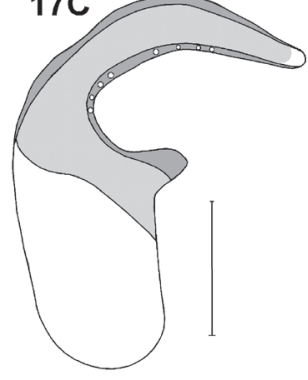

19B

19C
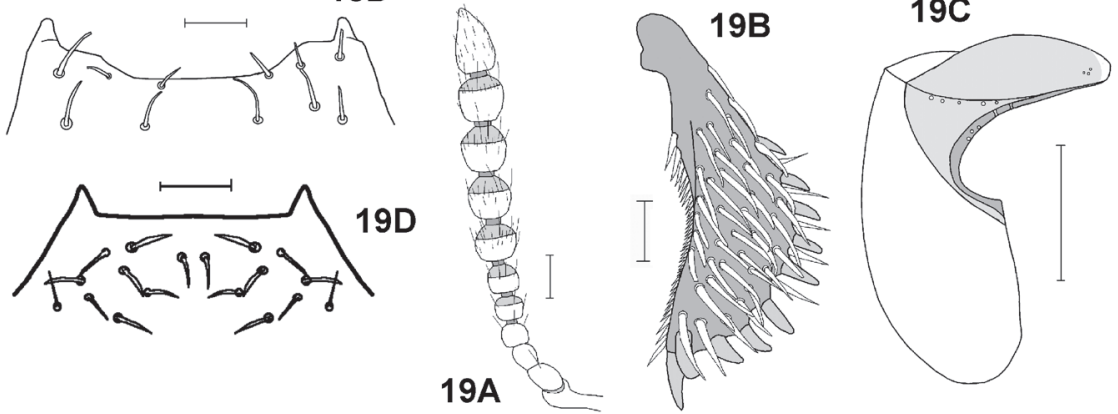

Fig. 16-19: Osoriellus-bicornis-group: Osoriellus sinuatoangularis (16), O. subsinuatus (17), O. corniculatus (18), O. sinuatus (19); antenna (A), protibia (B), aedeagus in lateral aspect (C), anterior edge of clypeus (D); scale bar: $0.1 \mathrm{~mm}$. 

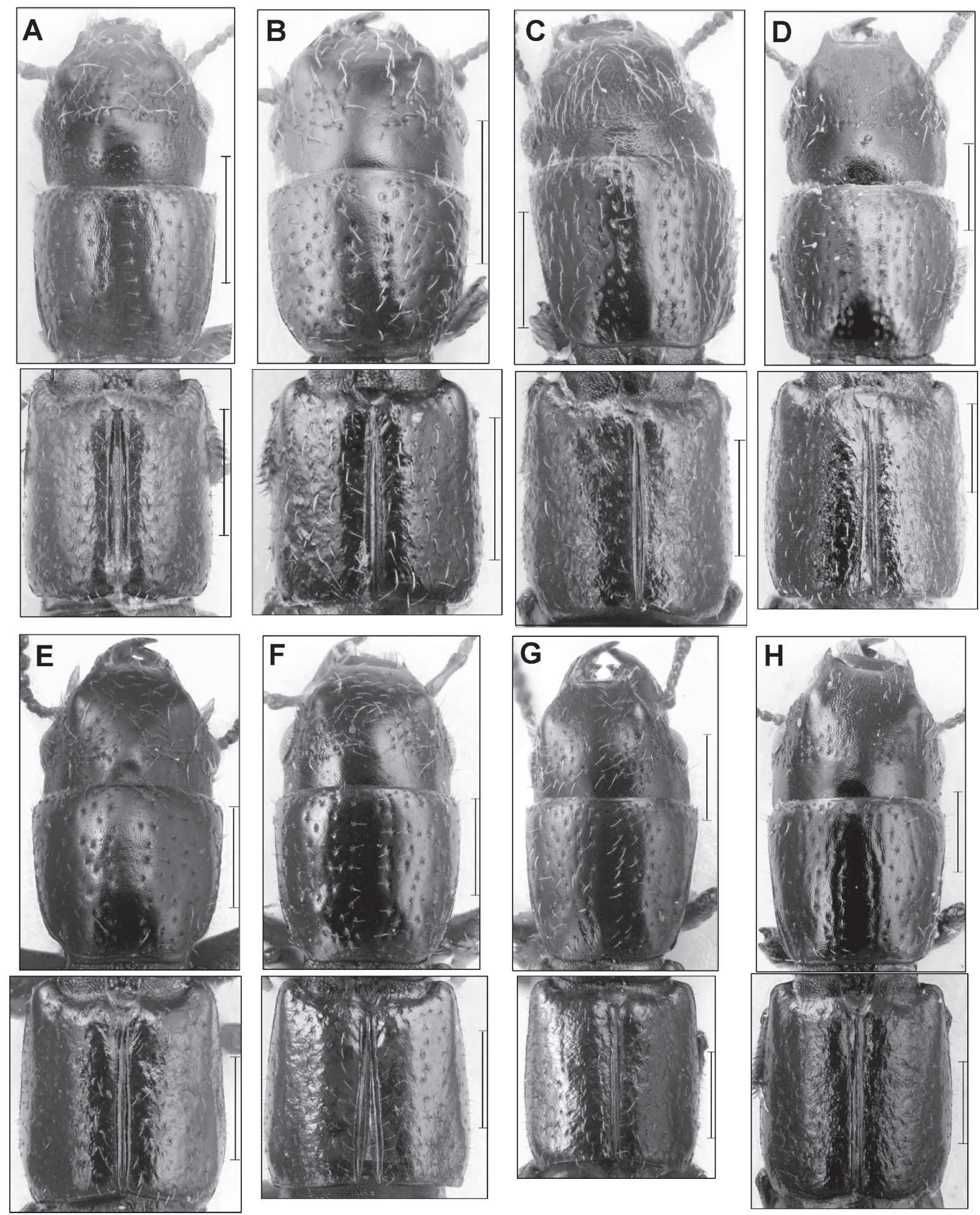

Fig. 20: Osoriellus-bicornis-group: Head, pronotum and elytra of Osoriellus bicornis (A), O. spinosus (B), O. bovis (C), O. cornutus (D), O. sinuatus (E), O. sinuatoangularis (F), O. subsinuatus (G), O. corniculatus $(\mathrm{H})$; scale bar: $0.5 \mathrm{~mm}$. 

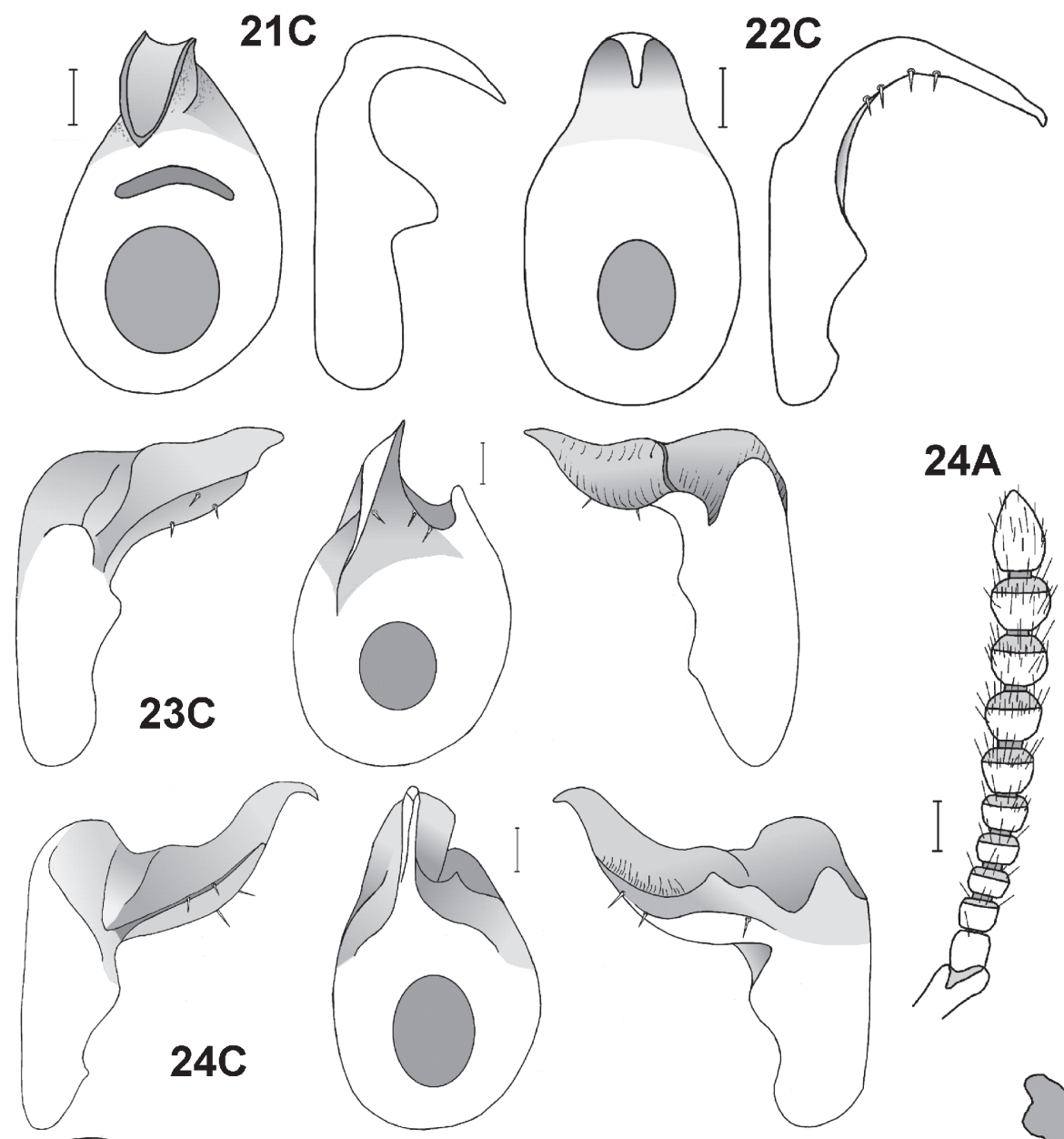

24A
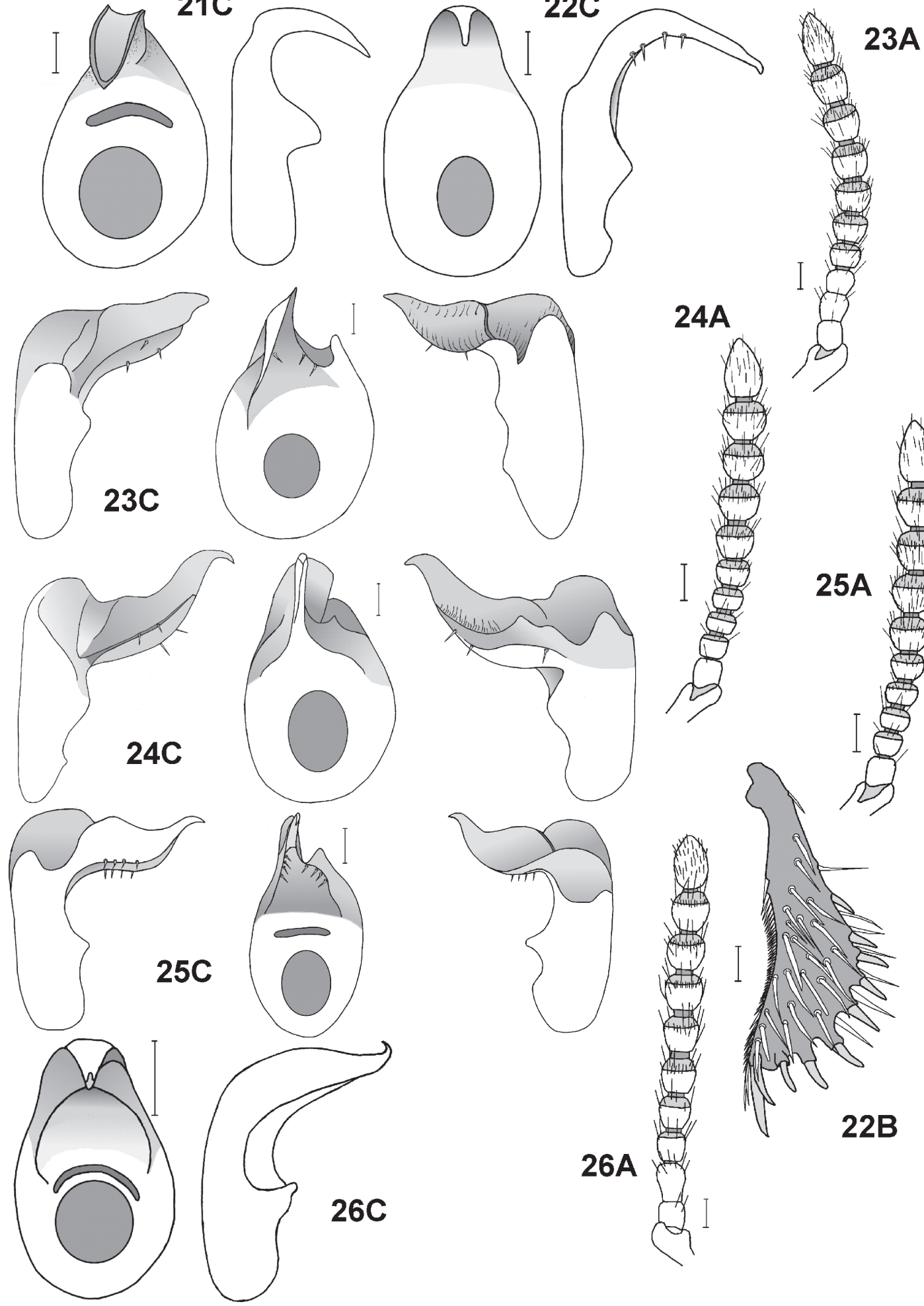

$3 A$
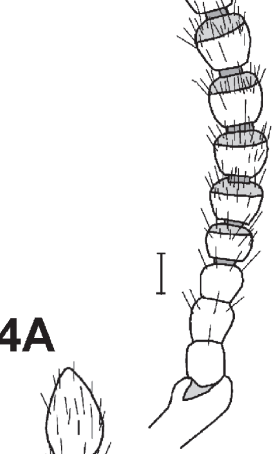

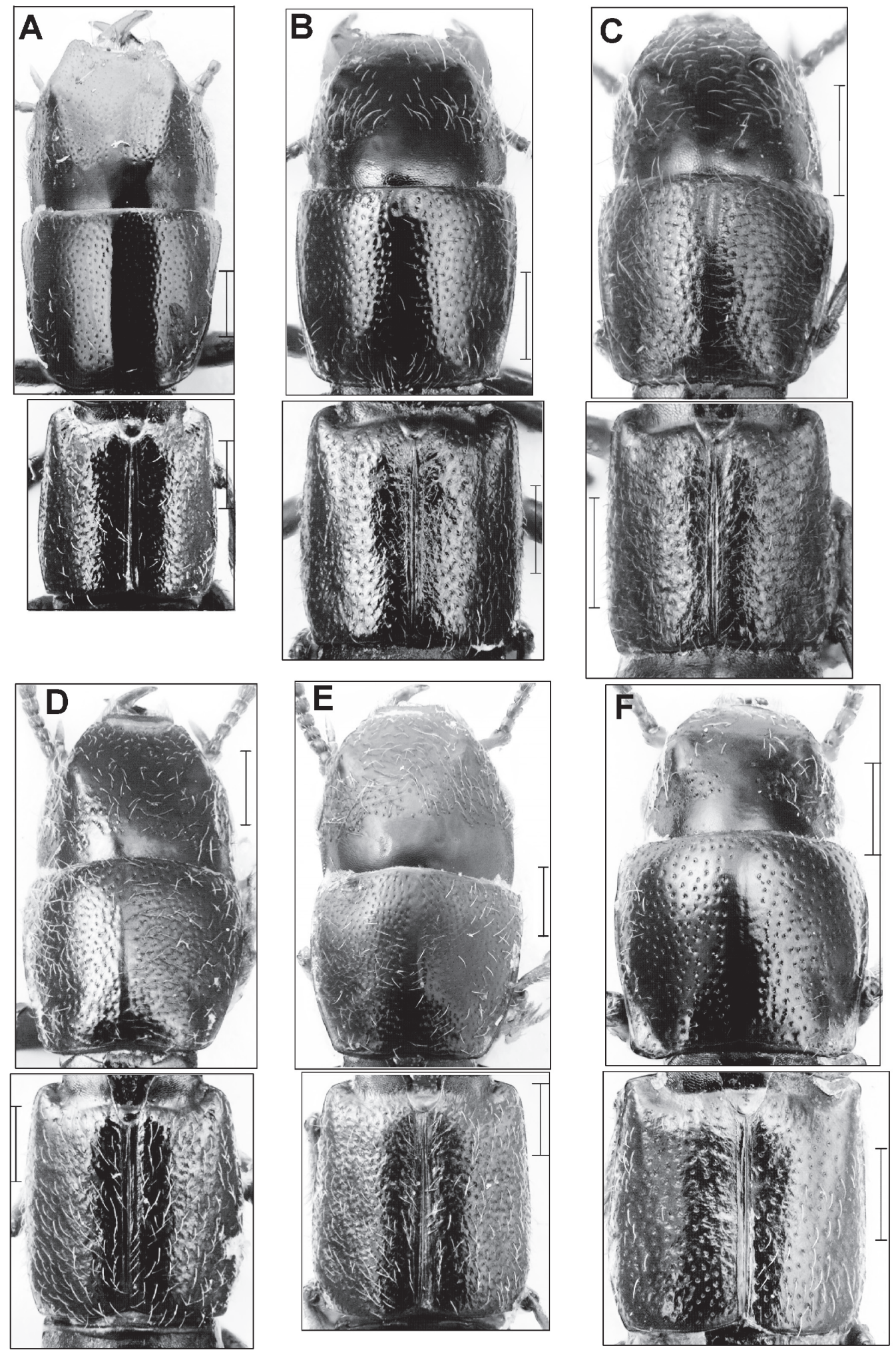

Fig. 27: Osoriellus-hirtulus-group: Head and pronotum and elytra of Osoriellus hirtulus (A), O. pubicollis (B), O. setulosus (C), O. pubescens (D), O. setosus (E), O. setifer (F); scale bar: $0.5 \mathrm{~mm}$. 


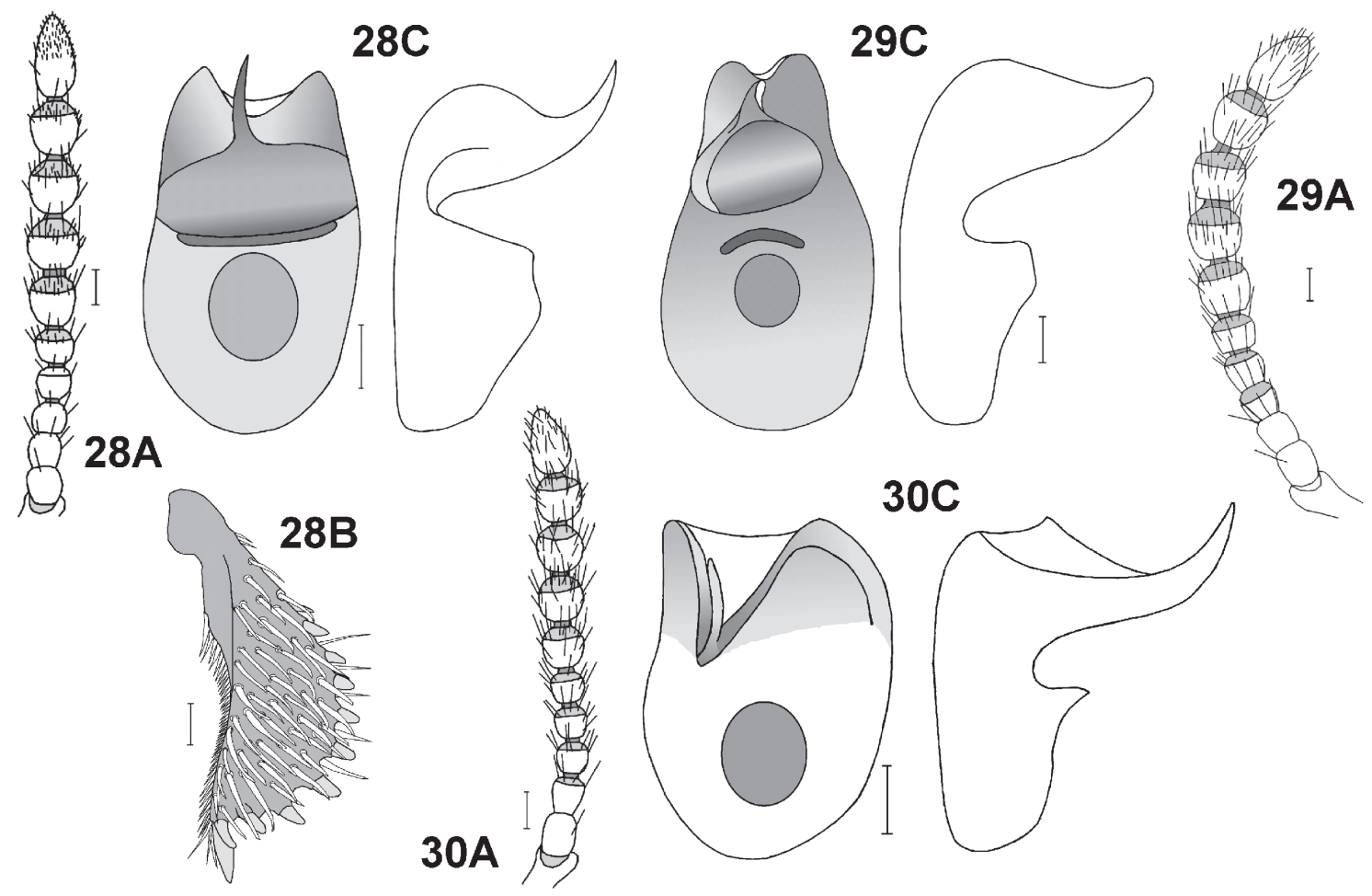

Fig. 28-30: Osoriellus-granarius-group: Osoriellus granarius (28), O. anceps (29), O. cornifrons (30); antenna (A), protibia (B), aedeagus in ventral and lateral aspect $(\mathrm{C})$; scale bar: $0.1 \mathrm{~mm}$.
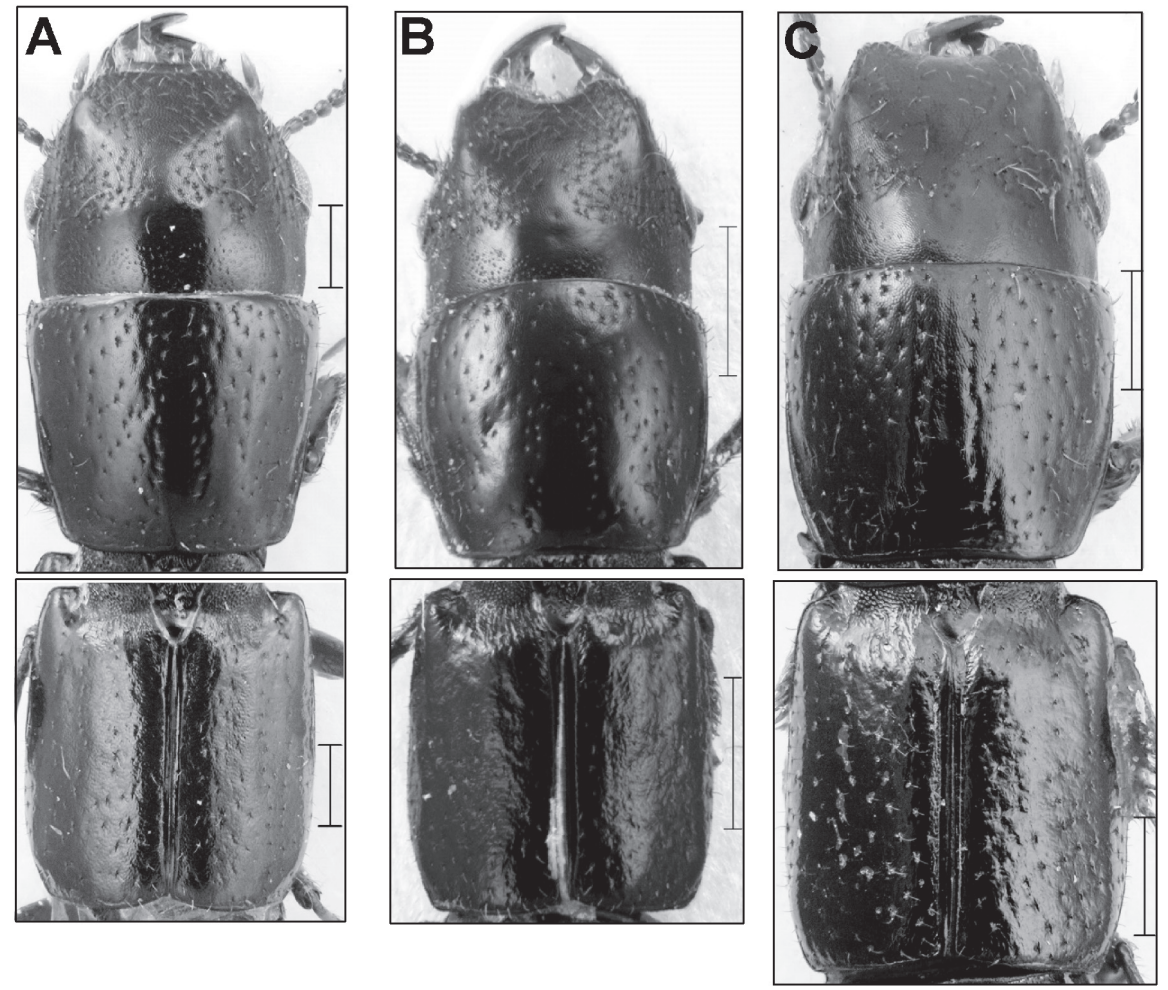

Fig. 31: Osoriellus-granarius-group: Head, pronotum and elytra of Osoriellus granarius (A), O. anceps (B), O. cornifrons (C); scale bar: $0.5 \mathrm{~mm}$. 

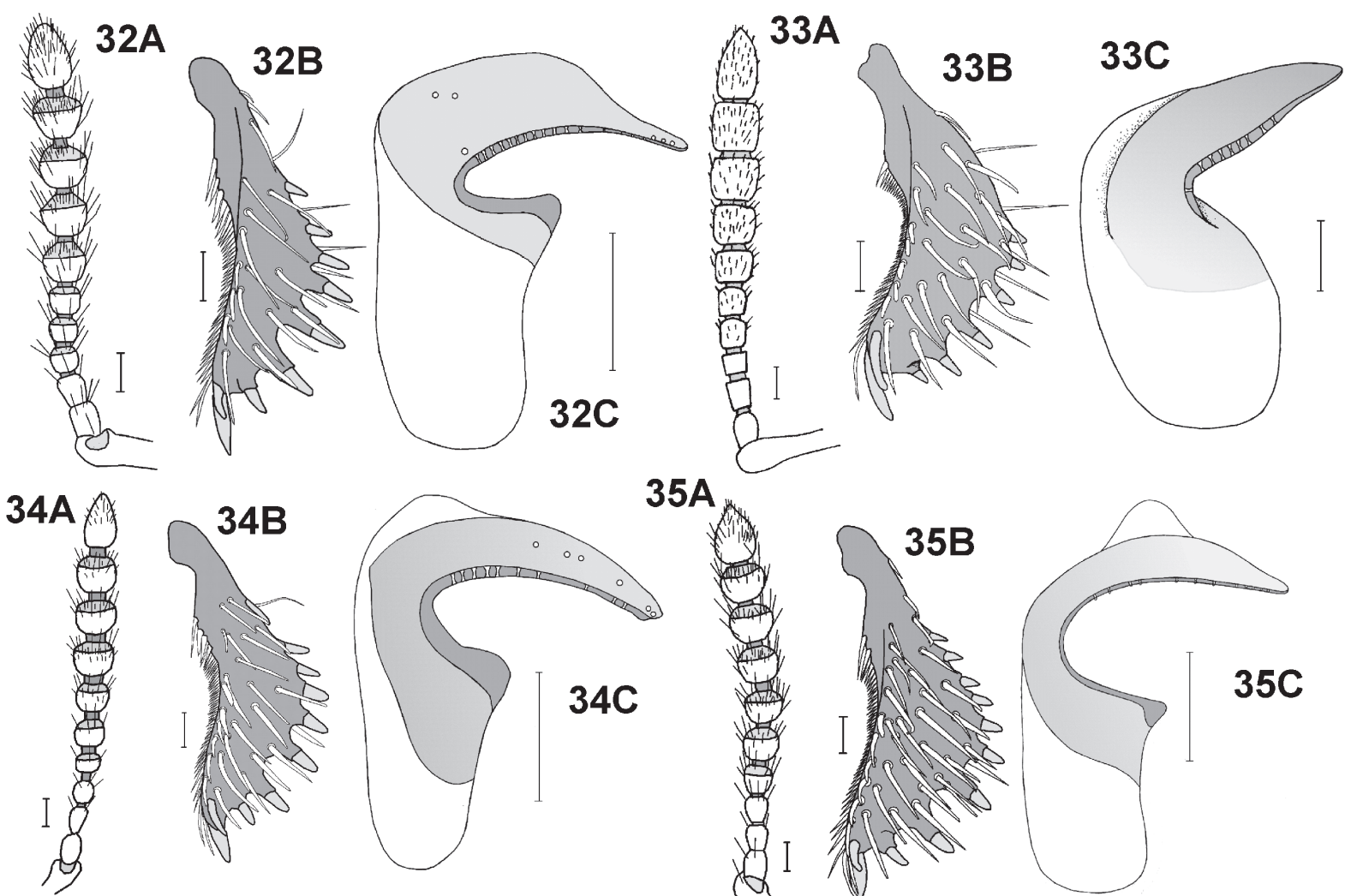

$35 \mathrm{~A}$
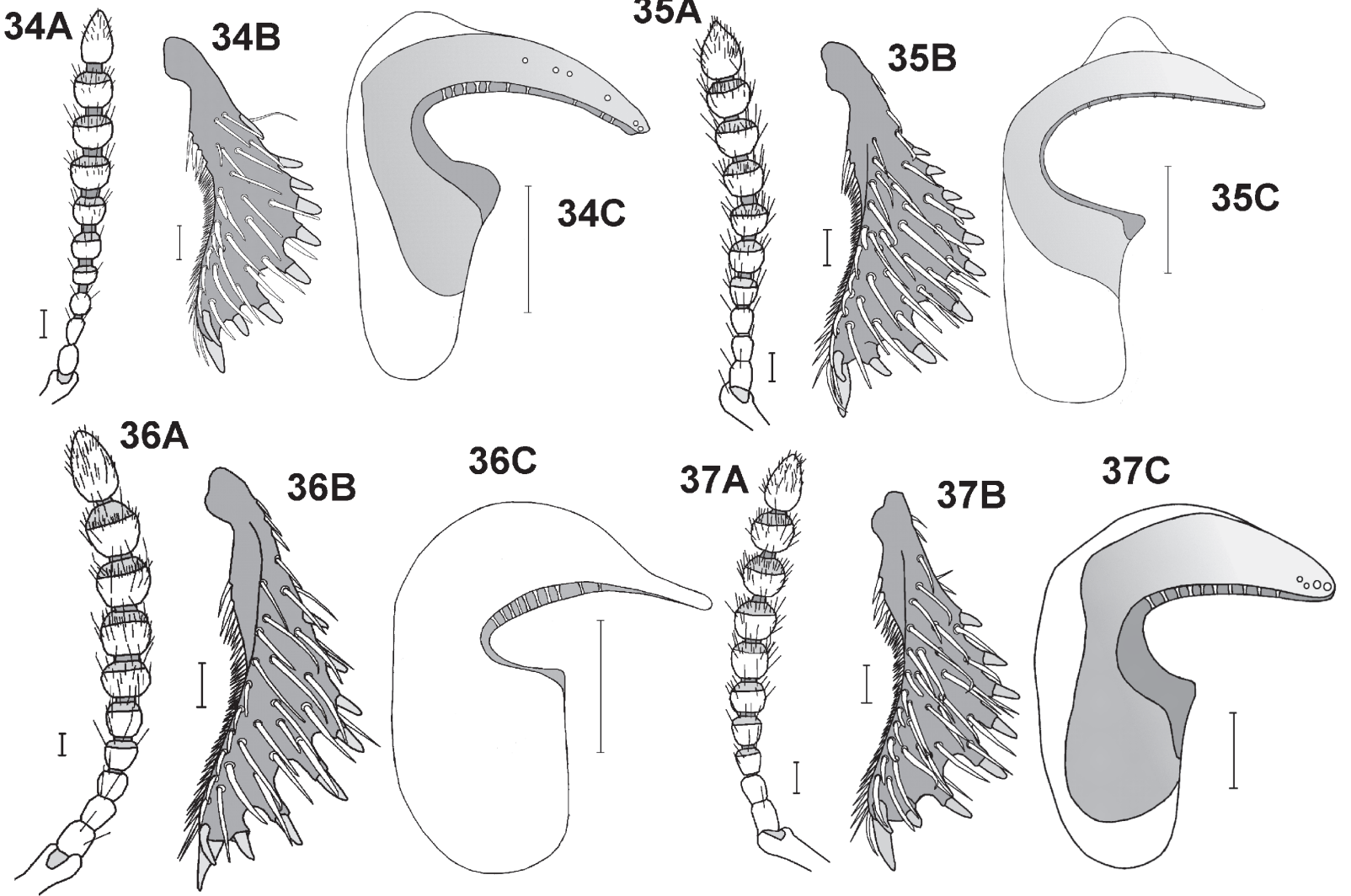

Fig. 32-37: Osoriellus-guiananus-group: Osoriellus guiananus (32), O. breviceps (33), O. solidus (34), O. macrops (35), O. melancholicus (36), O. diversus (37); antenna (A), protibia (B), aedeagus in lateral aspect (C); scale bar: $0.1 \mathrm{~mm}$. 

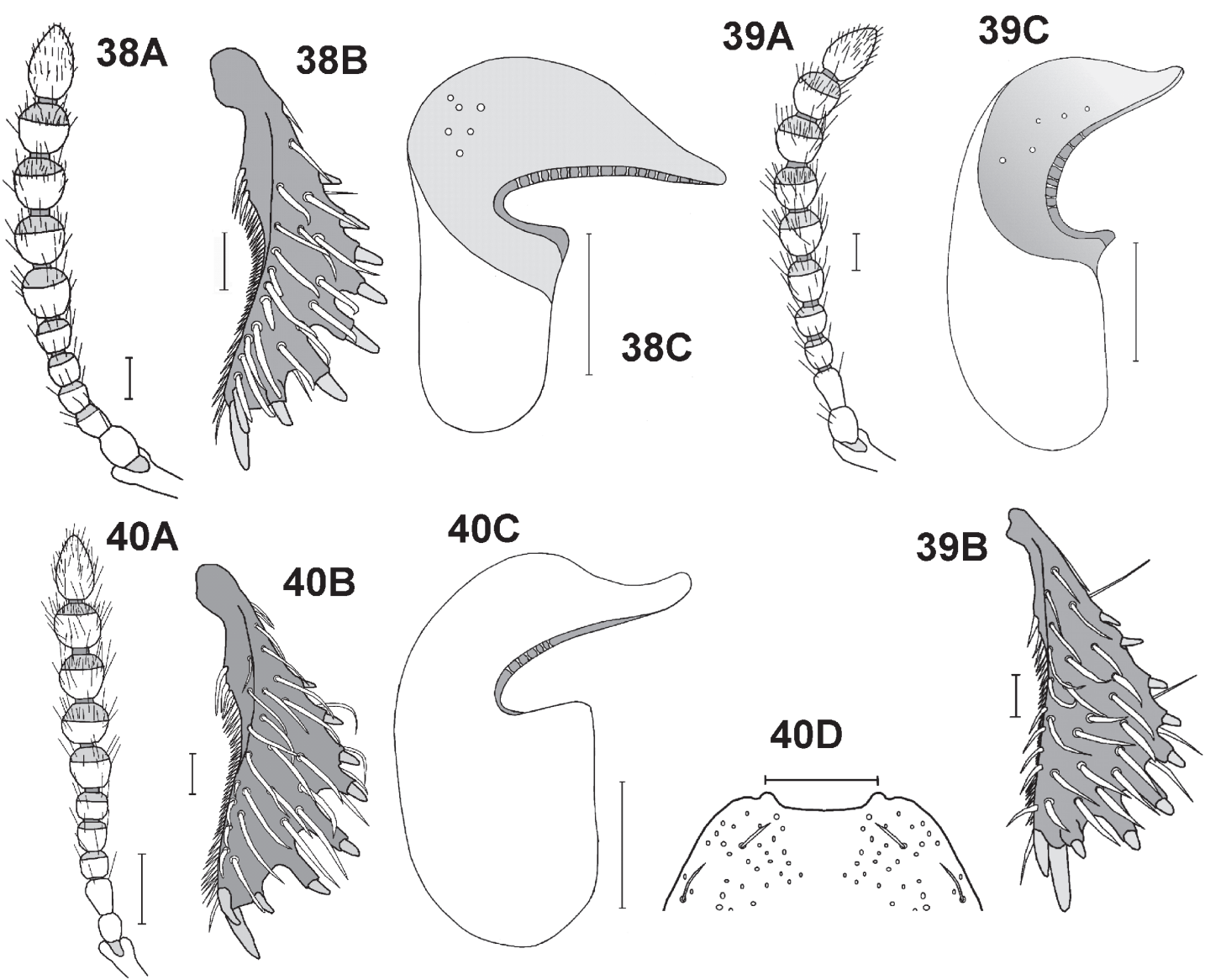

Fig. 38-40: Osoriellus-guiananus- and -mrazi-group: Osoriellus longipunctatus (38), Osoriellus silvaticus (39), O. mrazi (40); antenna (A), protibia (B), aedeagus in lateral aspect (C), clypeus (D); scale bar: $0.1 \mathrm{~mm}$. 

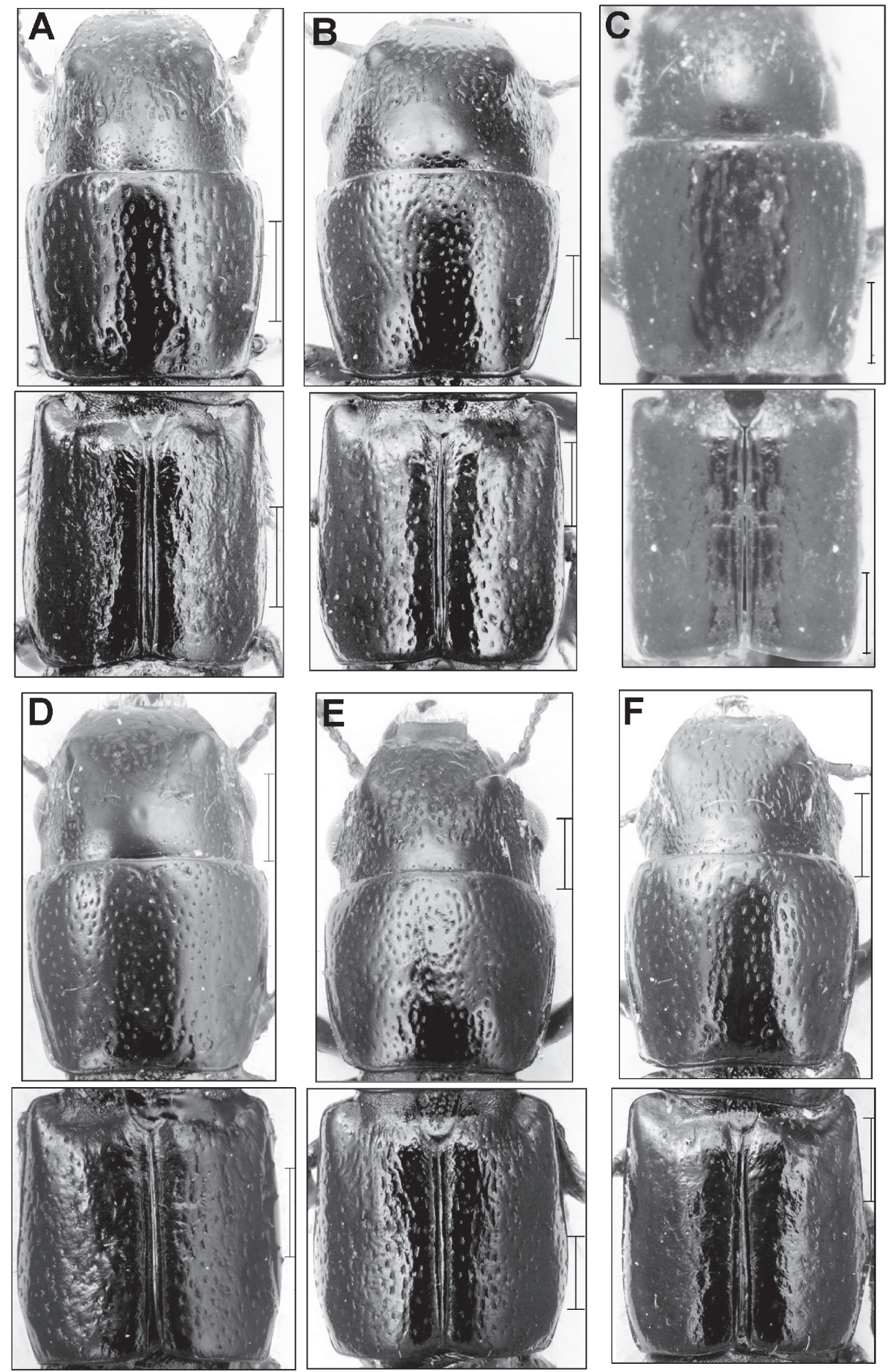

Fig. 41: Osoriellus-guiananus-group: Head, pronotum and elytra of Osoriellus guiananus (A), O. solidus (B), O. breviceps (C), O. diversus (D), O. macrops (E), O. melancholicus (F); scale bar: $0.5 \mathrm{~mm}$. 

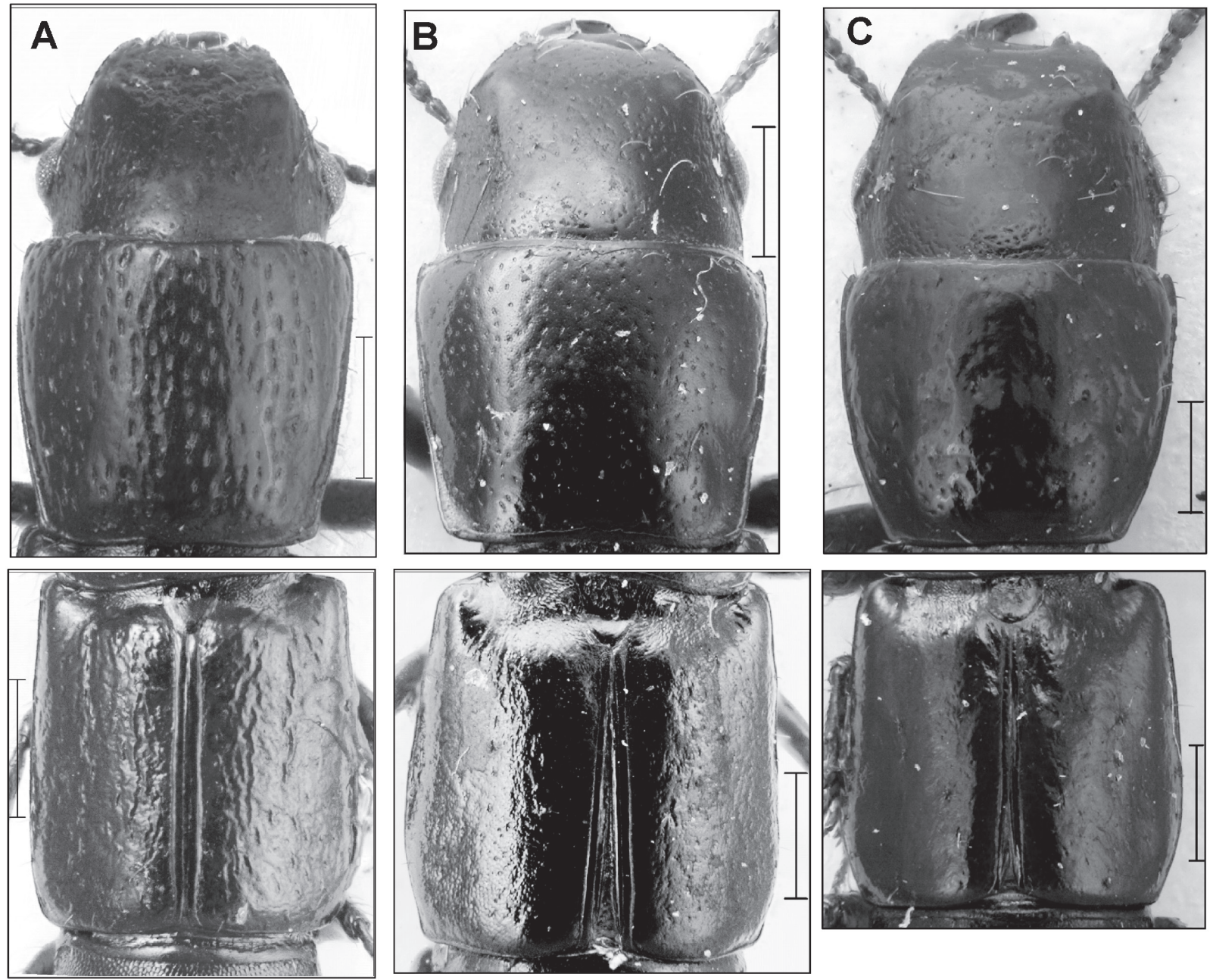

Fig. 42: Osoriellus-guiananus- and -mrazi-group: Head, pronotum and elytra of Osoriellus longipunctatus (A), O. silvaticus (B), O. $m$ razi (C); scale bar: $0.5 \mathrm{~mm}$. 


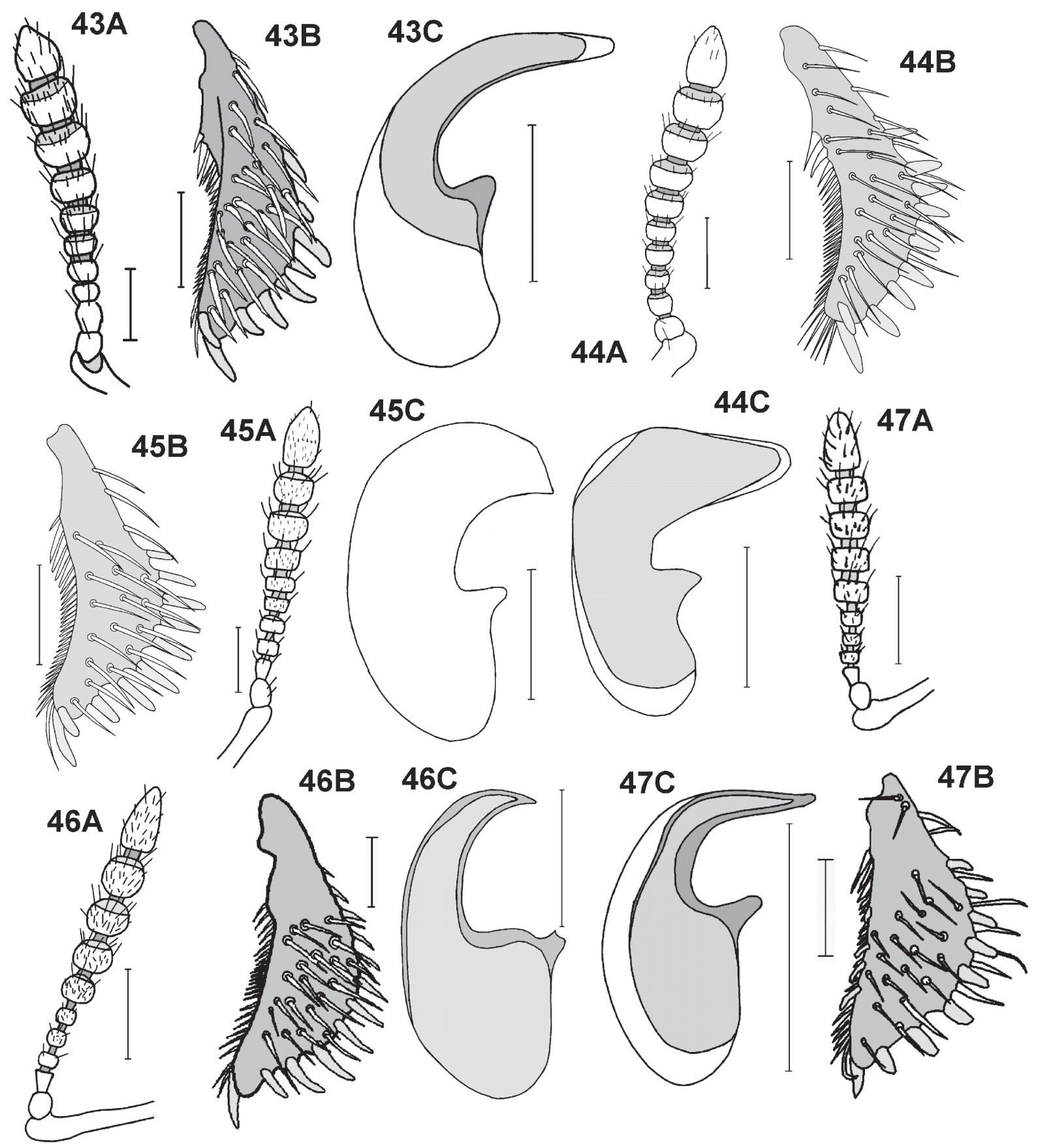

Fig. 43-47: Osoriellus-s. str.-group: O. exiguus (43), Osoriellus indescriptus (44), O. coruscus (45), O. luteus (46); O. punctatellus (47); antenna (A), protibia (B), aedeagus in lateral aspect (C); scale bar: $0.1 \mathrm{~mm}$. 

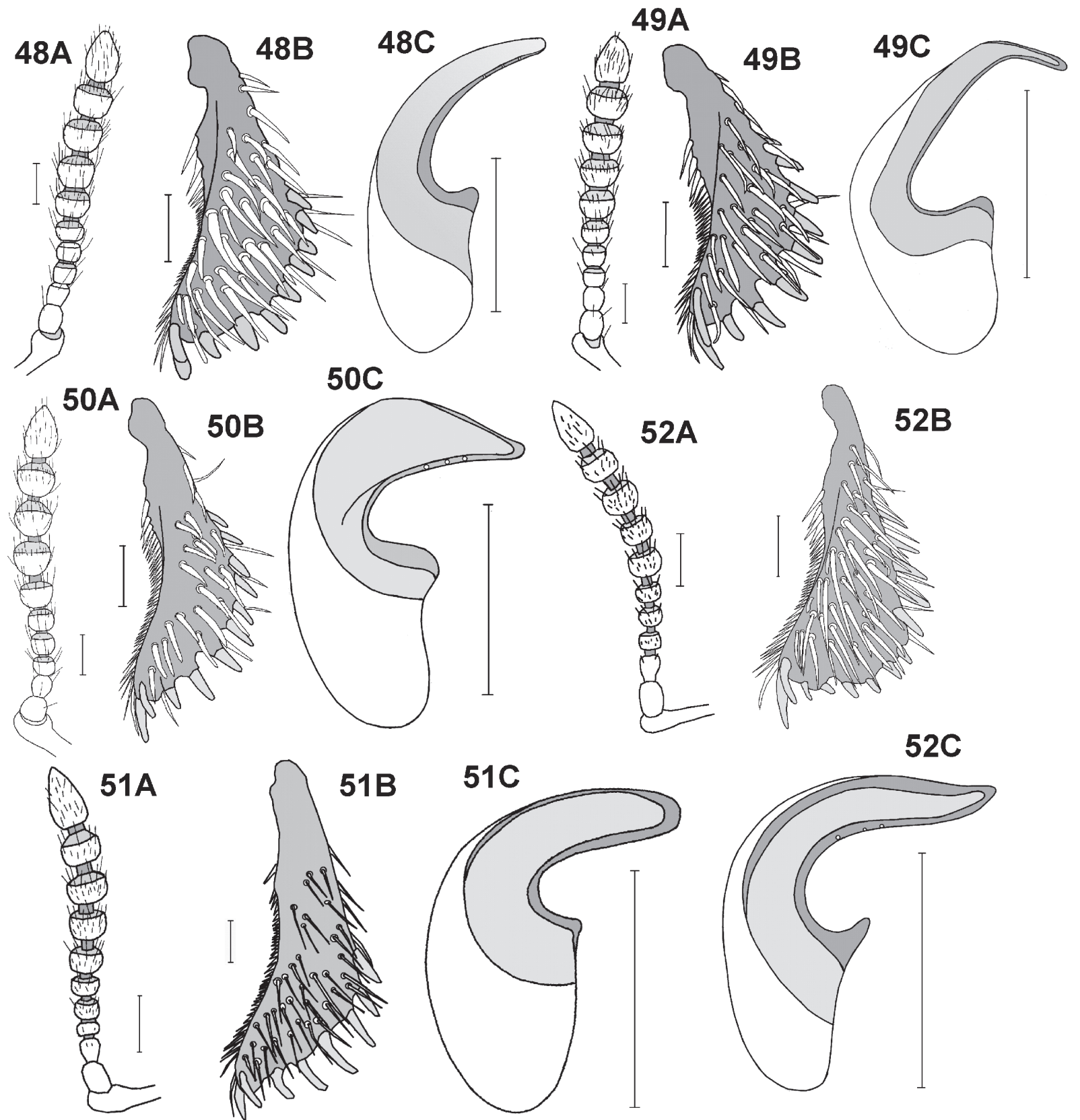

Fig. 48-52: Osoriellus-s. str.-group: Osoriellus lewisi (48); O. huggerti (49), O. flaveolus (50), O. coriaceus (51), O. latitibialis (52); antenna (A), protibia (B), aedeagus in lateral aspect (C); scale bar: $0.1 \mathrm{~mm}$. 

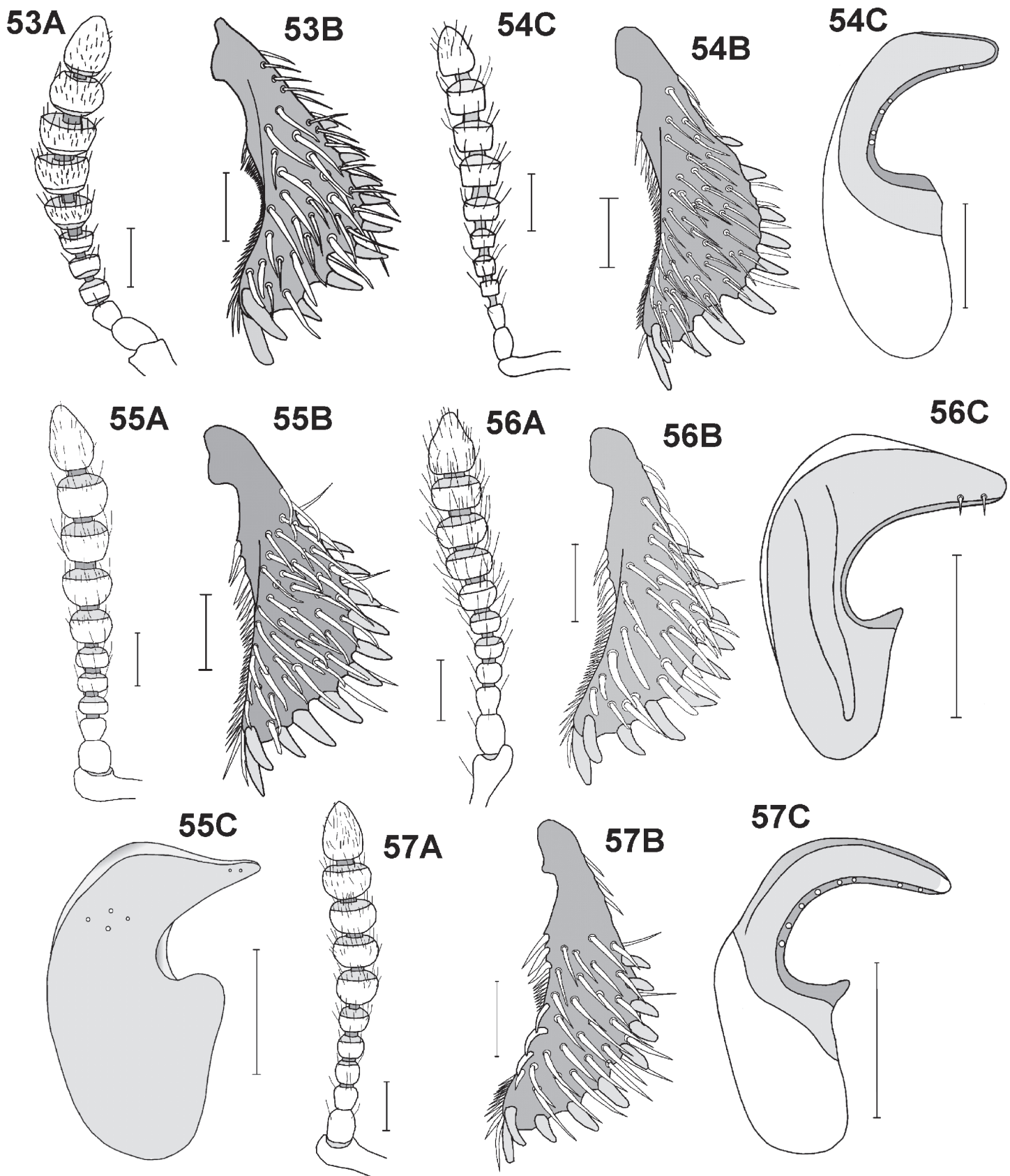

Fig. 53-57: Osoriellus-s. str.-group: Osoriellus brevicornis (53), O. micros (54), O. surinamensis (55), O. grossopunctatus (55); Osoriellus ashei (57); antenna (A), protibia (B), aedeagus in lateral aspect (C); scale bar: $0.1 \mathrm{~mm}$. 

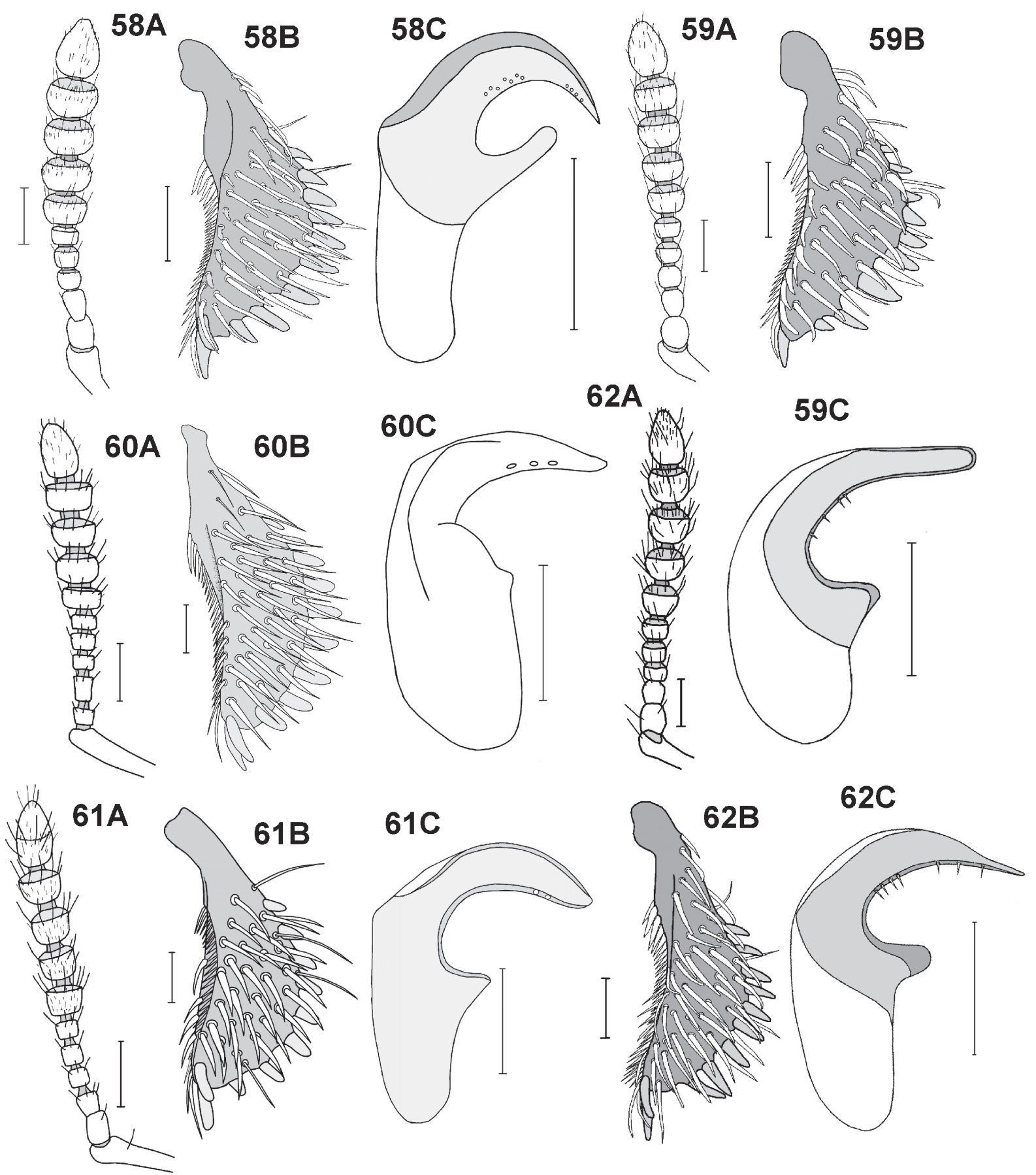

Fig. 58-62: Osoriellus-s. str.-group: Osoriellus levyi (58), O. loksai (59), O. bicolor (60), O. salvini (61), O. eggersi (62); antenna (A), protibia (B), aedeagus in lateral aspect (C); scale bar: $0.1 \mathrm{~mm}$. 

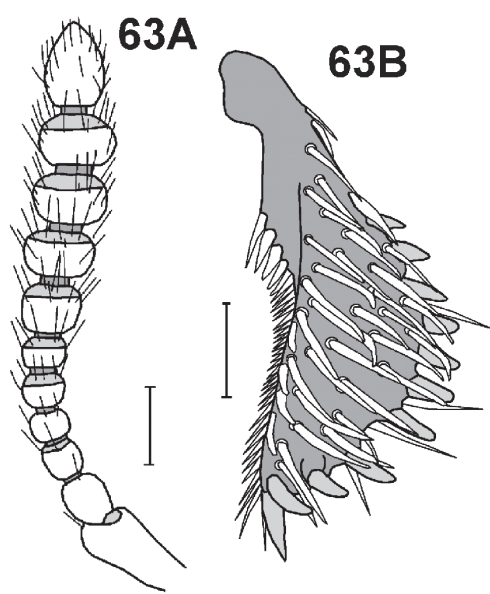

$63 \mathrm{C}$

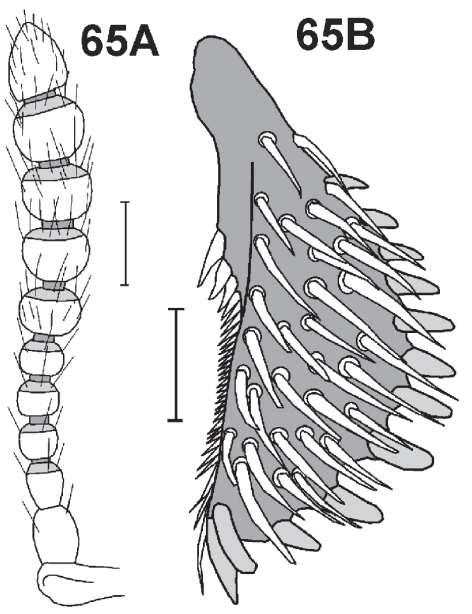

$65 \mathrm{C}$
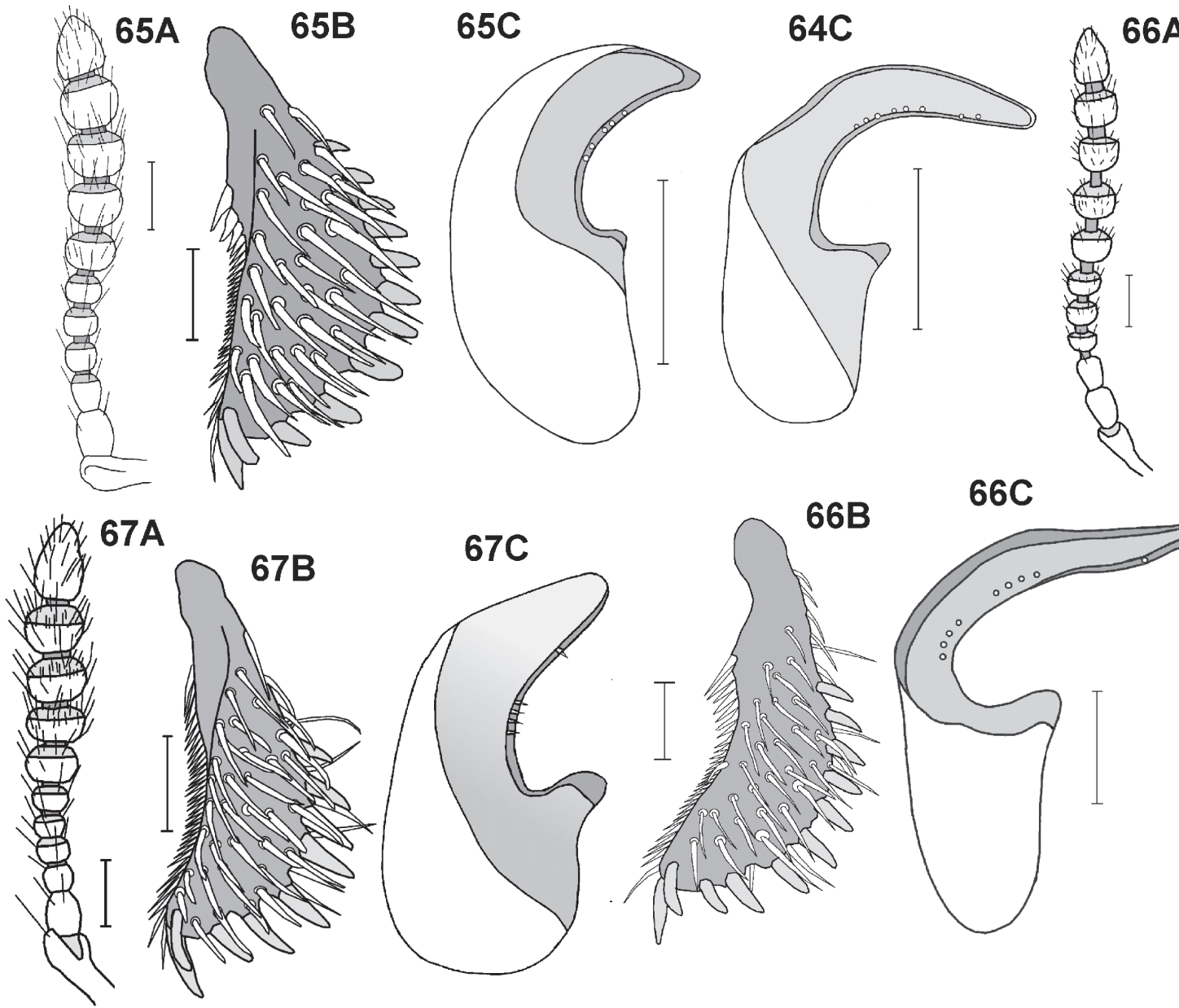

$7 \mathrm{~A}$
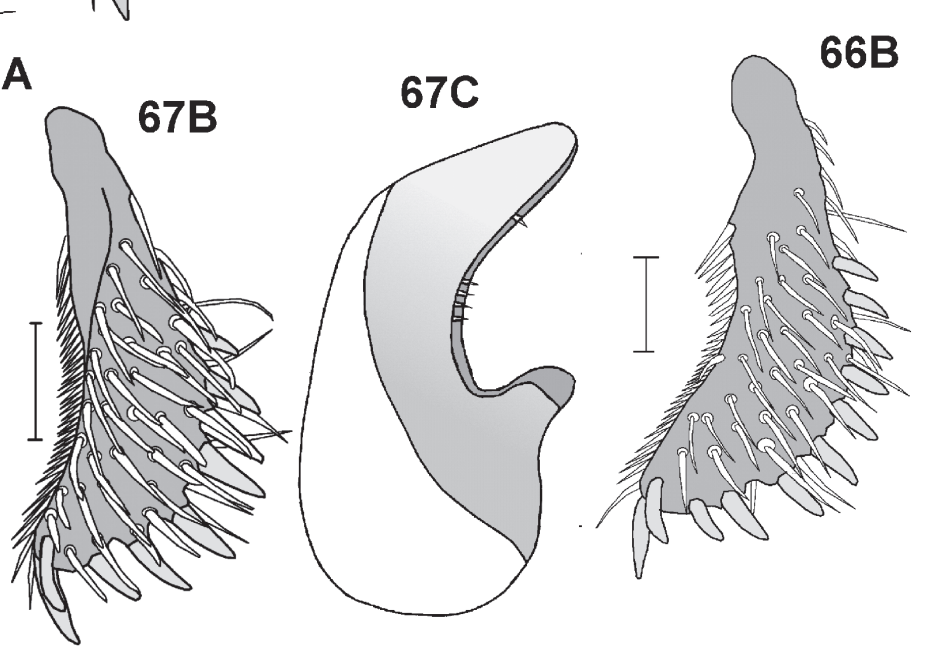

$66 \mathrm{C}$

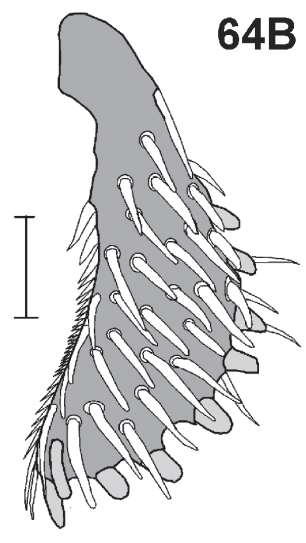

64B

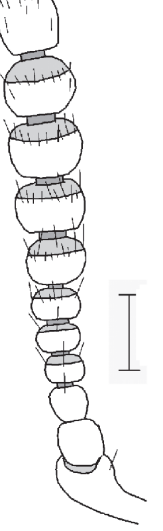



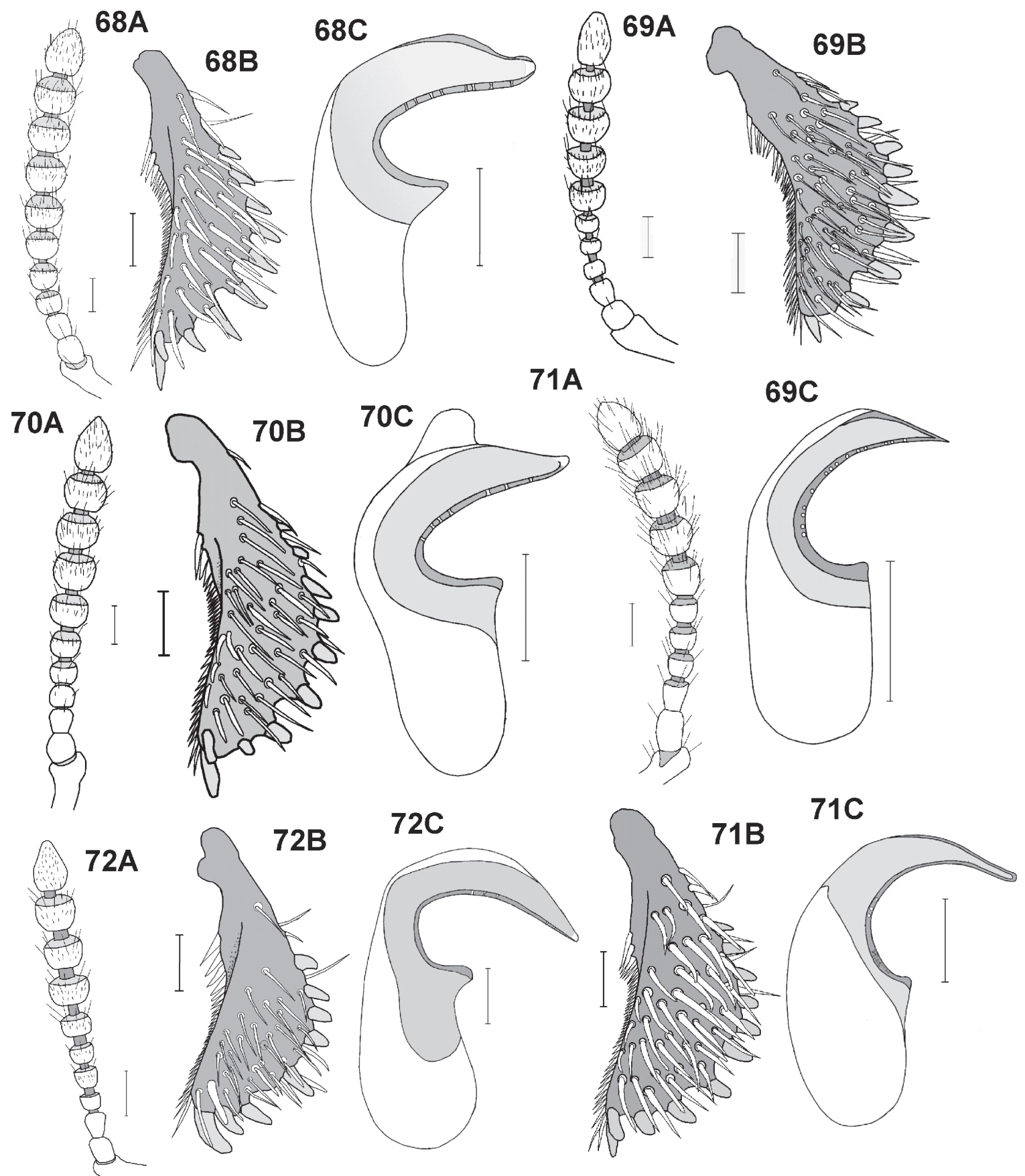

Fig. 68-72: Osoriellus-s. str.-group: Osoriellus boliviensis (68), O. minor (69), O. rugipennis (70), O. triangulatus (71), O. franckei (72); antenna (A), protibia (B), aedeagus in lateral aspect (C); scale bar: $0.1 \mathrm{~mm}$. 


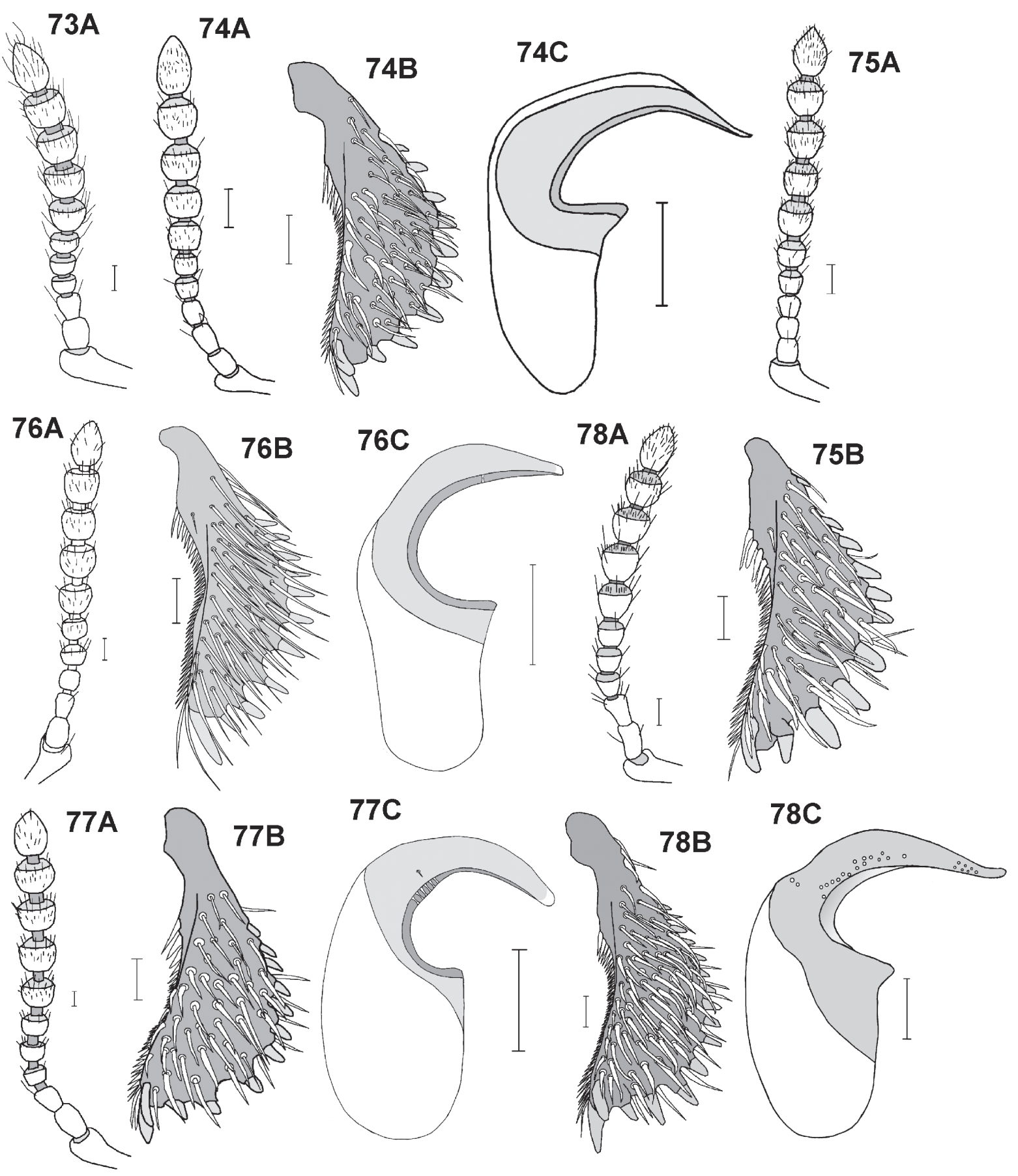

Fig. 73-78: Osoriellus-s. str.-group: Osoriellus frater (73), O. latipes (74); O. mexicanus (75), O. brevipennis (76), O. argentinus (77), O. crassus (78); antenna (A), protibia (B), aedeagus in lateral aspect (C); scale bar: $0.1 \mathrm{~mm}$. 

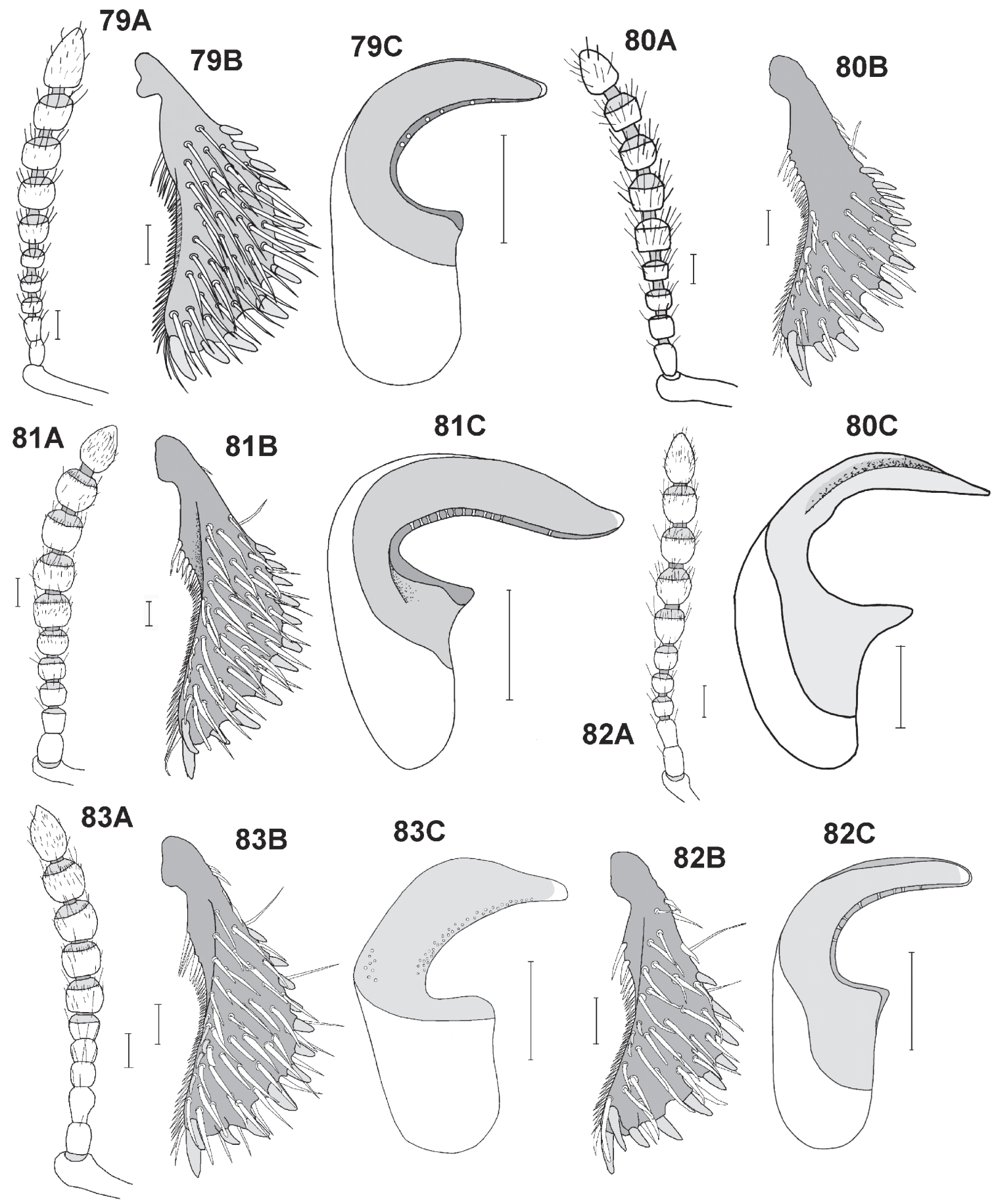

$83 \mathrm{C}$
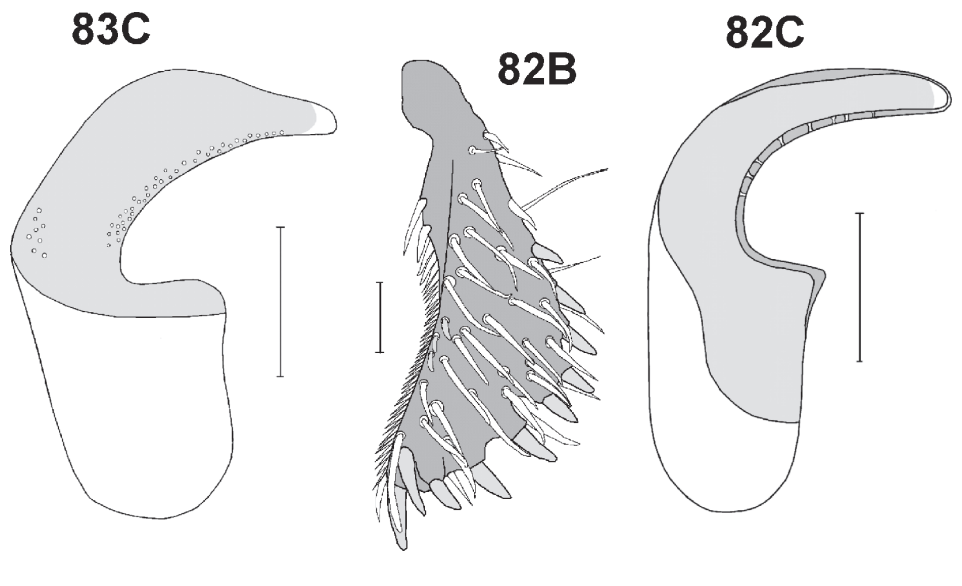

Fig. 79-83: Osoriellus-s. str.-group: Osoriellus debilis (79), O. parcus (80), O. schwarzi (81), O. trapezoides (82), O. opacus (83); antenna (A), protibia (B), aedeagus in lateral aspect (C); scale bar: $0.1 \mathrm{~mm}$. 


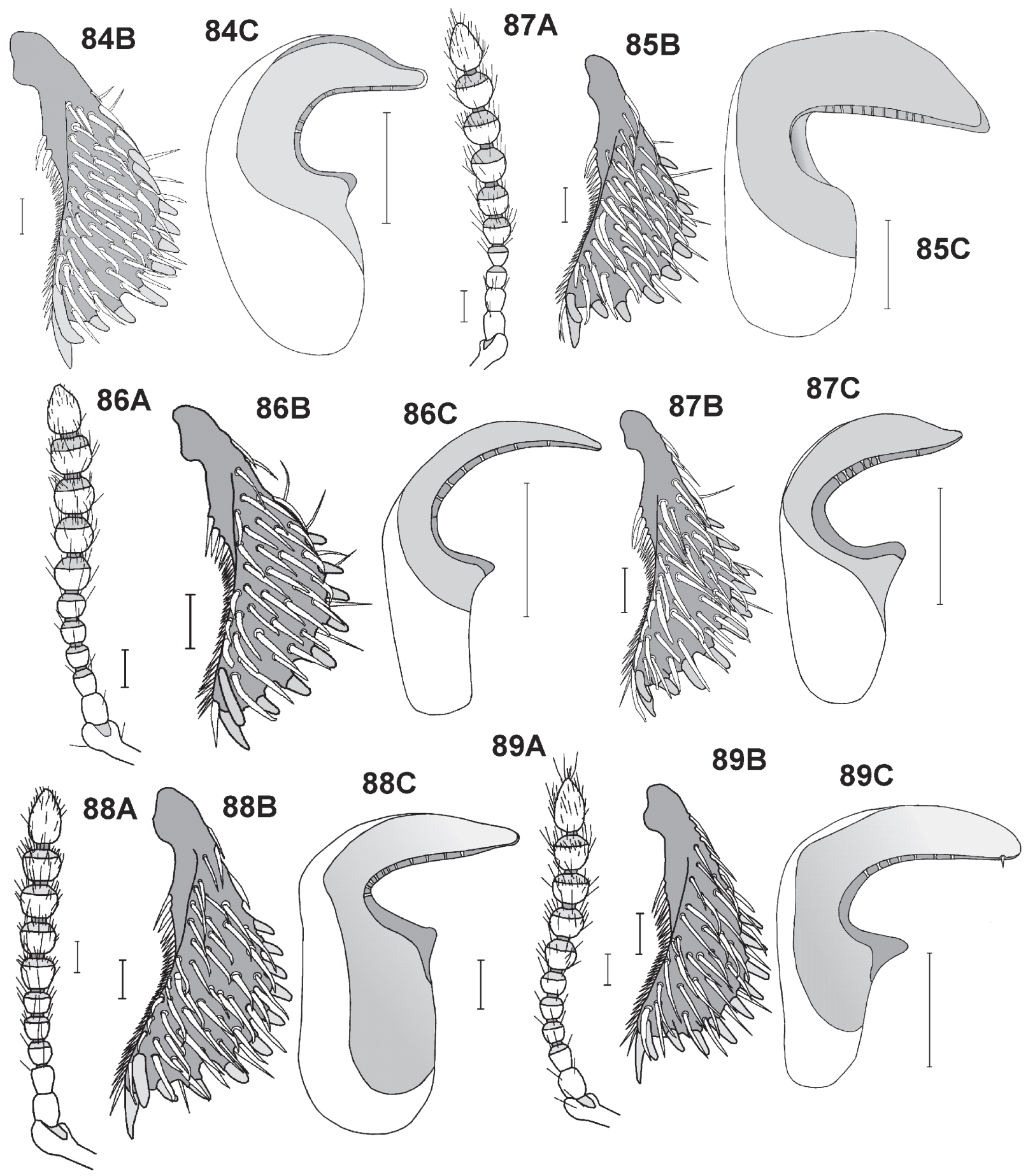

Fig. 84-89: Osoriellus-s. str.-group: Osoriellus rougemonti (84), O.tunariensis (85), O. haitiellus (86), O. multipunctatus (87), O. verhaaghi (88), O. rubripennis (89); antenna (A), protibia (B), aedeagus in lateral aspect (C); scale bar: $0.1 \mathrm{~mm}$. 

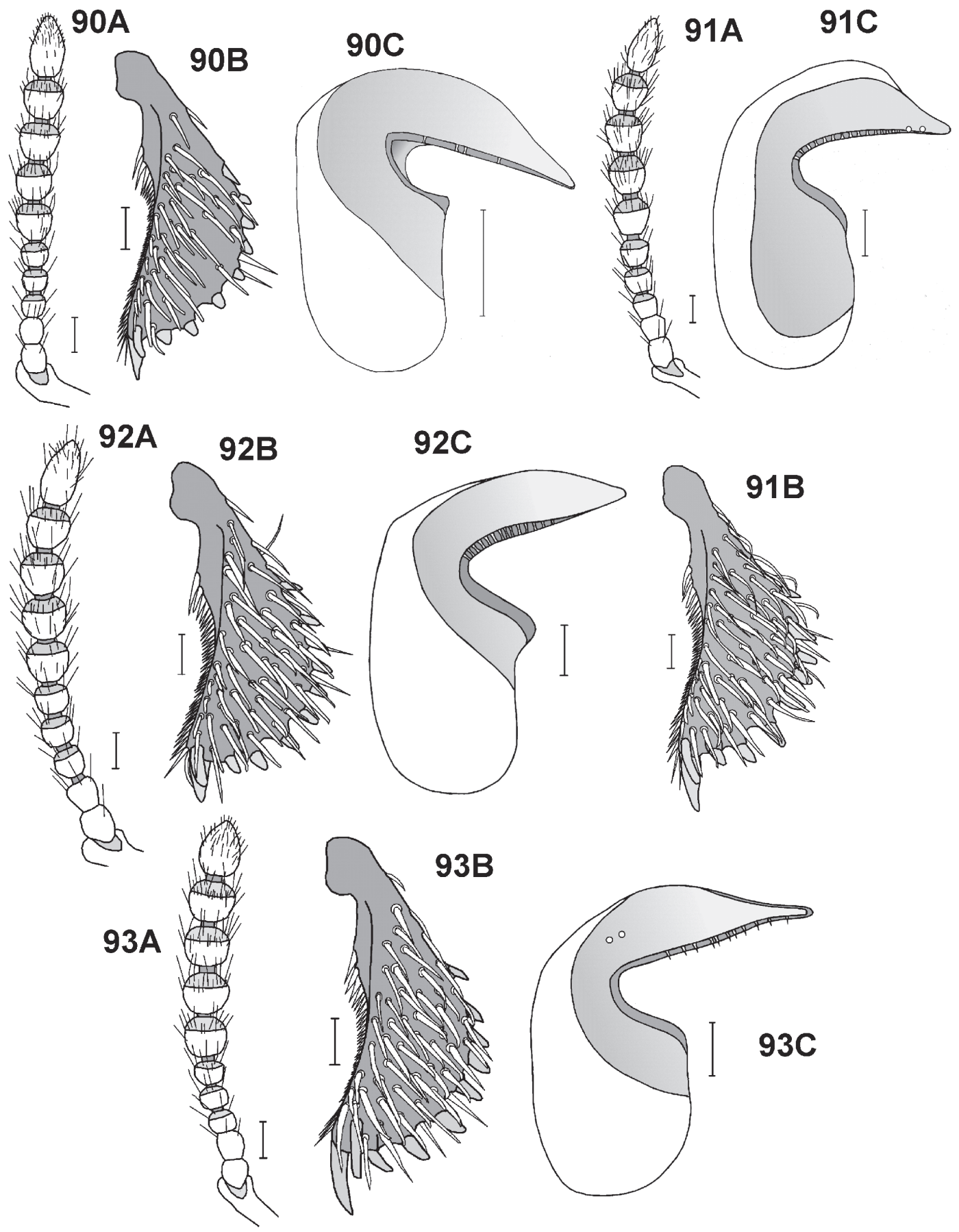

Fig. 90-93: Osoriellus-s. str.-group: Osoriellus seriatus (90), O. majusculus (91), O. fumarius (92), O. caliginosus (93); antenna (A), protibia (B), aedeagus in lateral aspect (C); scale bar: $0.1 \mathrm{~mm}$. 

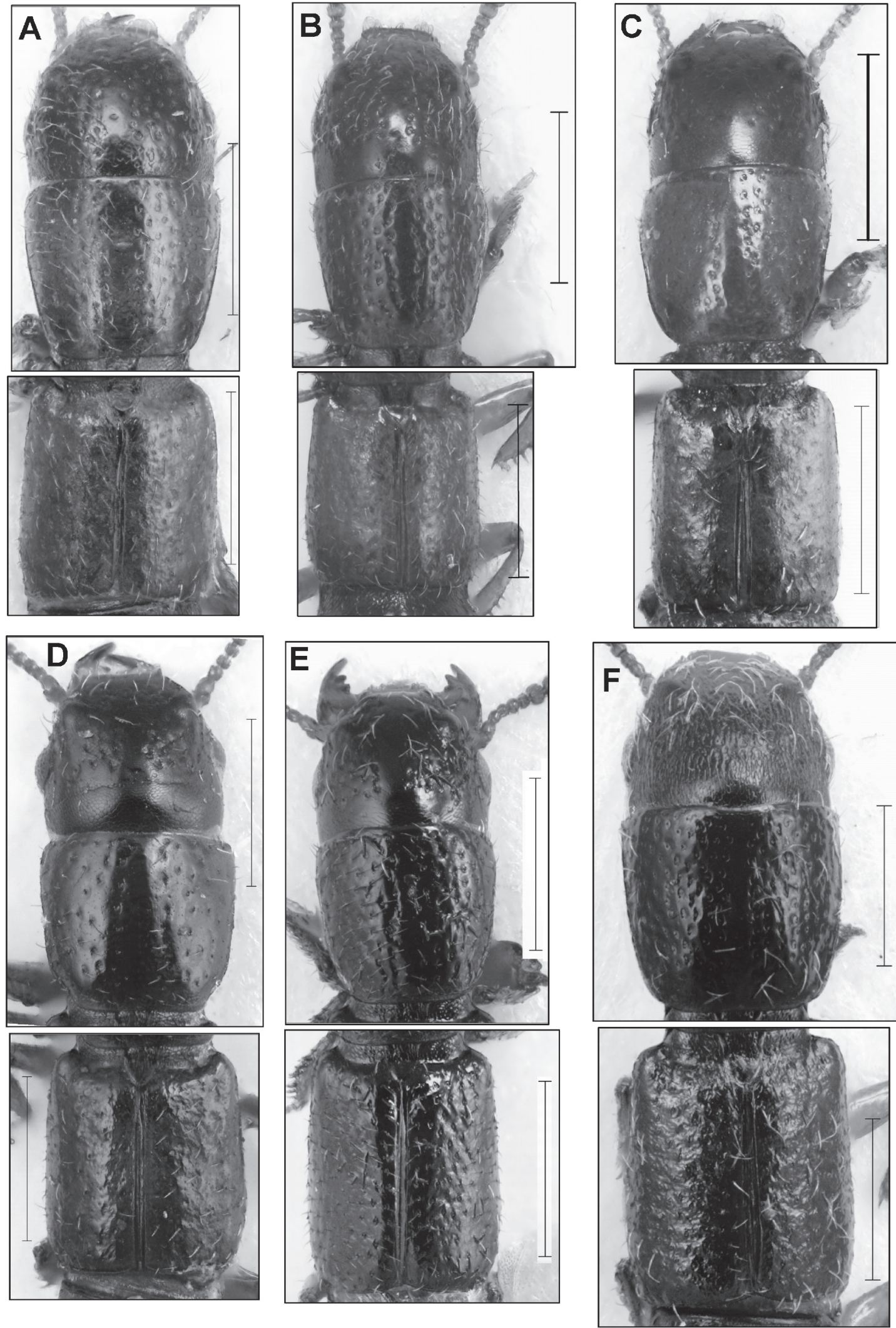

Fig. 94: Osoriellus-s. str.-group: Head, pronotum and elytra of Osoriellus exiguus (A), O. indescribtus (B), O. coruscus (C), O. luteus (D); O. punctatellus (E), O. coriaceus (F); scale bar: $0.5 \mathrm{~mm}$. 

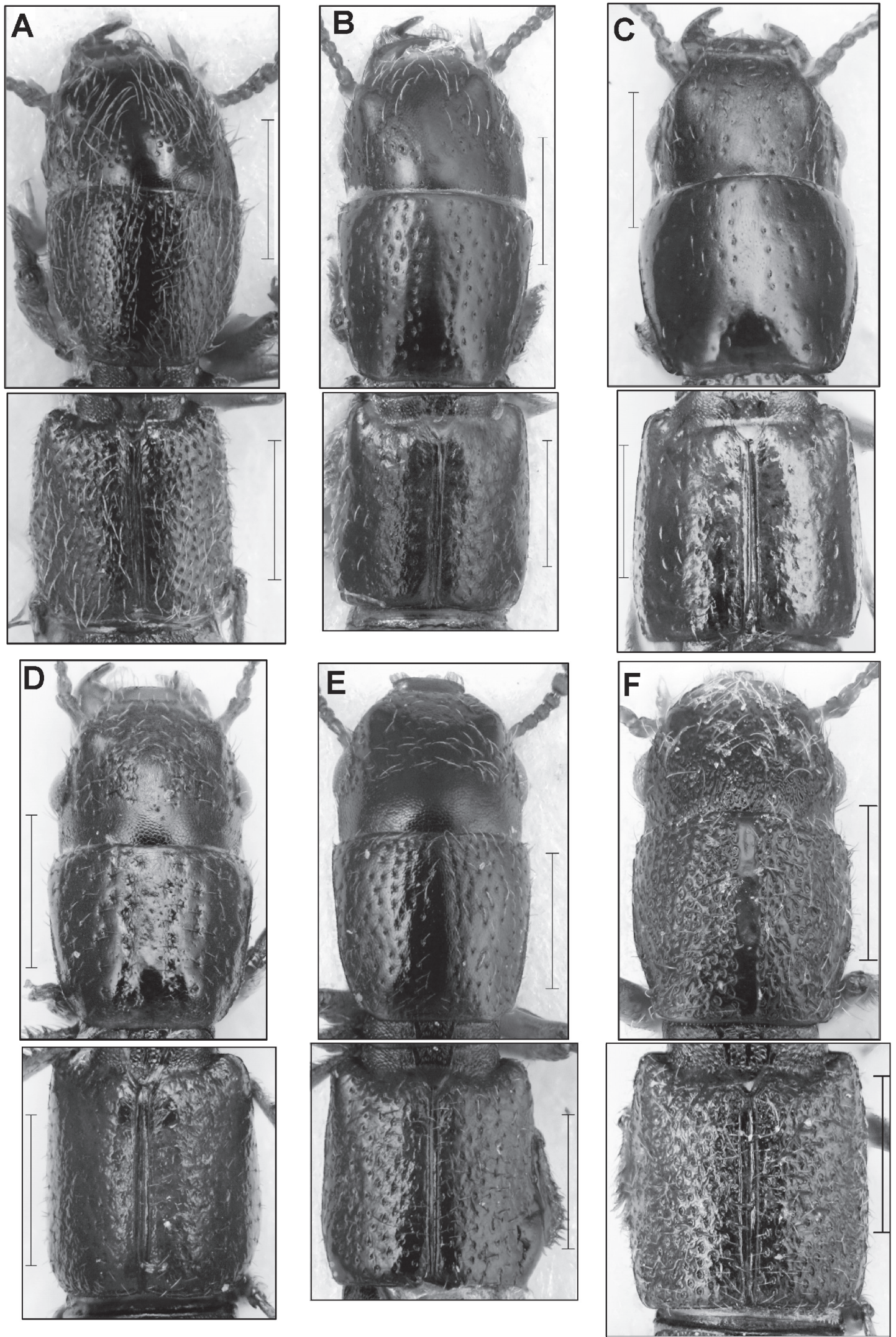

Fig. 95: Osoriellus-s. str.-group: Head, pronotum and elytra of Osoriellus latitibialis (A), O. huggerti (B), O. flaveolus (C), O. grossopunctatus (D), O. micros (E), O. asperatus (F); scale bar: $0.5 \mathrm{~mm}$. 

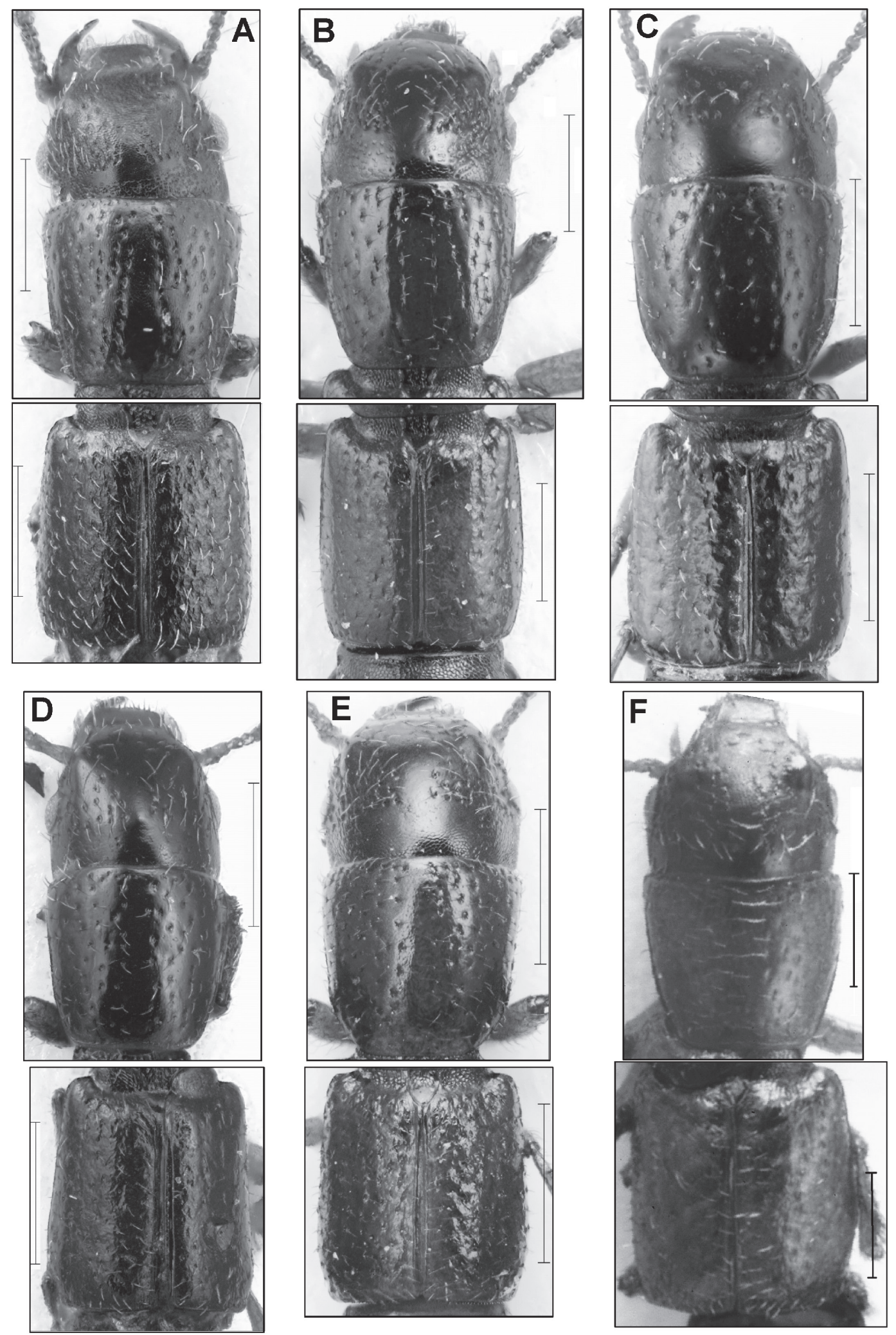

Fig. 96: Osoriellus-s. str.-group: Head, pronotum and elytra of O. surinamensis (A), O. salvini (B), O. obtusicollis (C), O. levyi (D), O. loksai (E), O. brevicornis (F); scale bar: $0.5 \mathrm{~mm}$. 

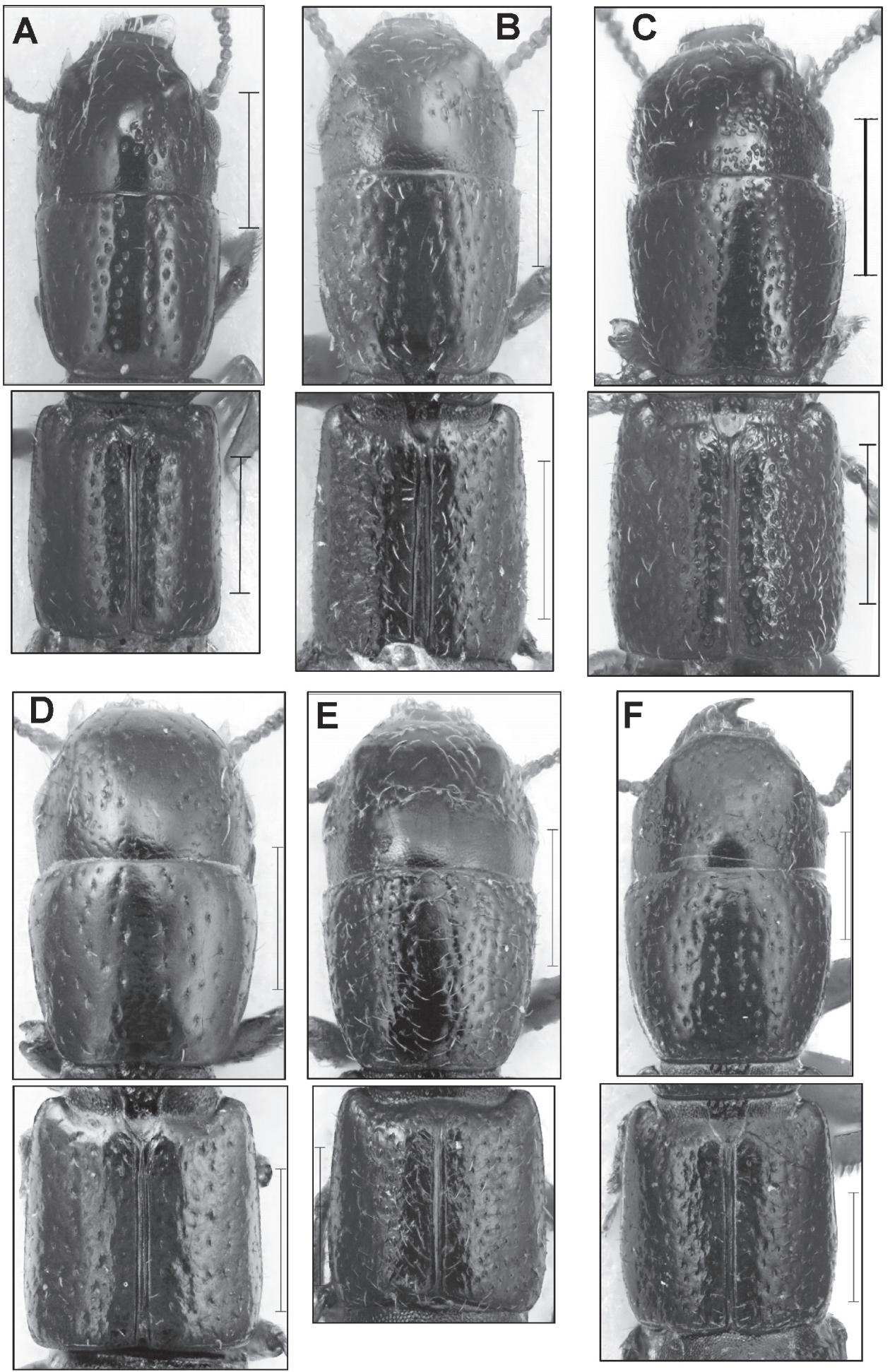

Fig. 97: Osoriellus-s. str.-group: Head, pronotum and elytra of Osoriellus bicolor (A), O. ashei (B), O. eggersi (C), O. parumpunctatus (D); O. humicola (E), O. minor (F); scale bar: $0.5 \mathrm{~mm}$. 

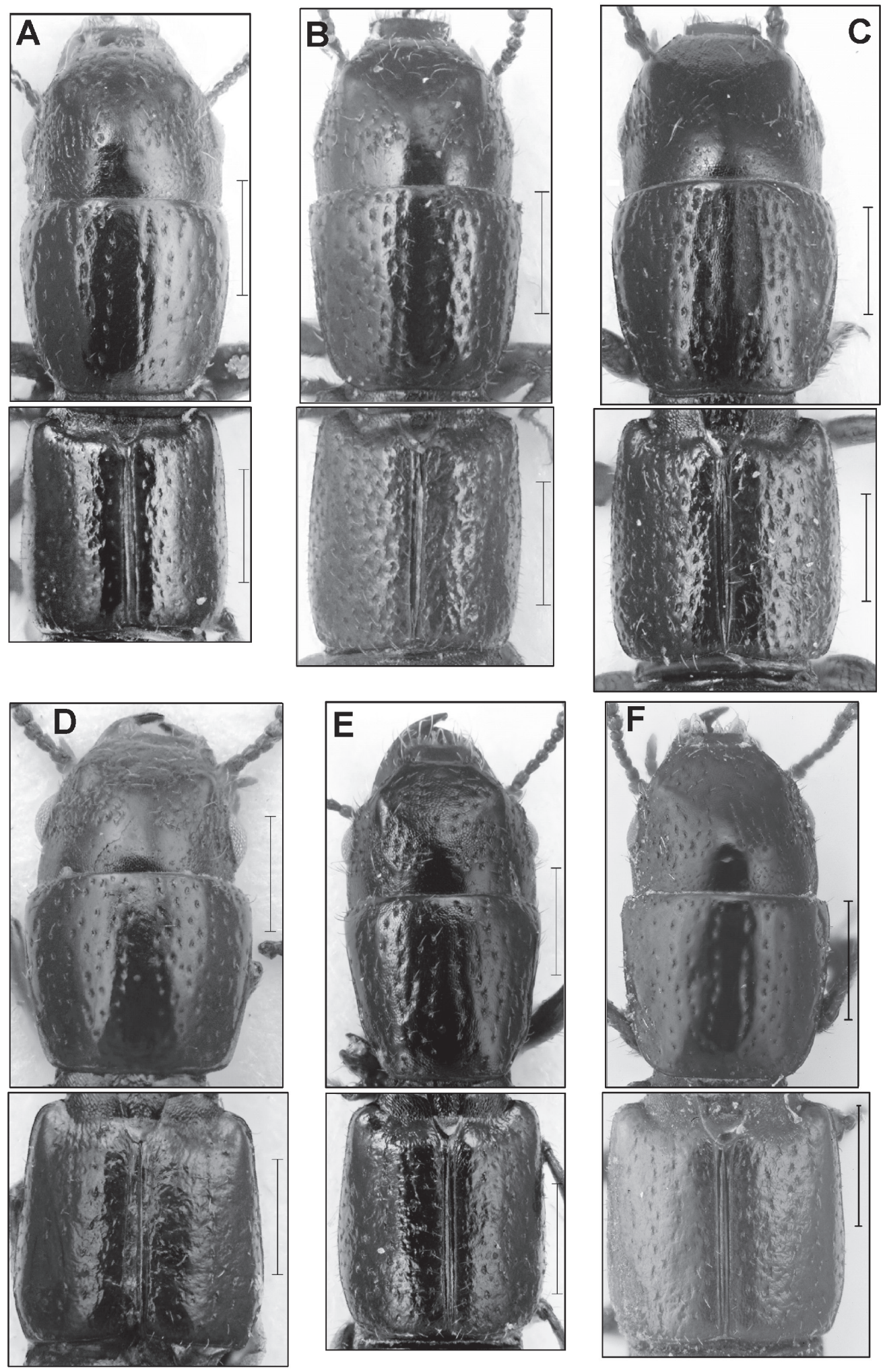

Fig. 98: Osoriellus-s. str.-group: Head, pronotum and elytra of Osoriellus franckei (F), O. tuxtlae (B); O. rugipennis (C), O. boliviensis (D), O. triangulatus (E), O. frater (F); scale bar: $0.5 \mathrm{~mm}$. 

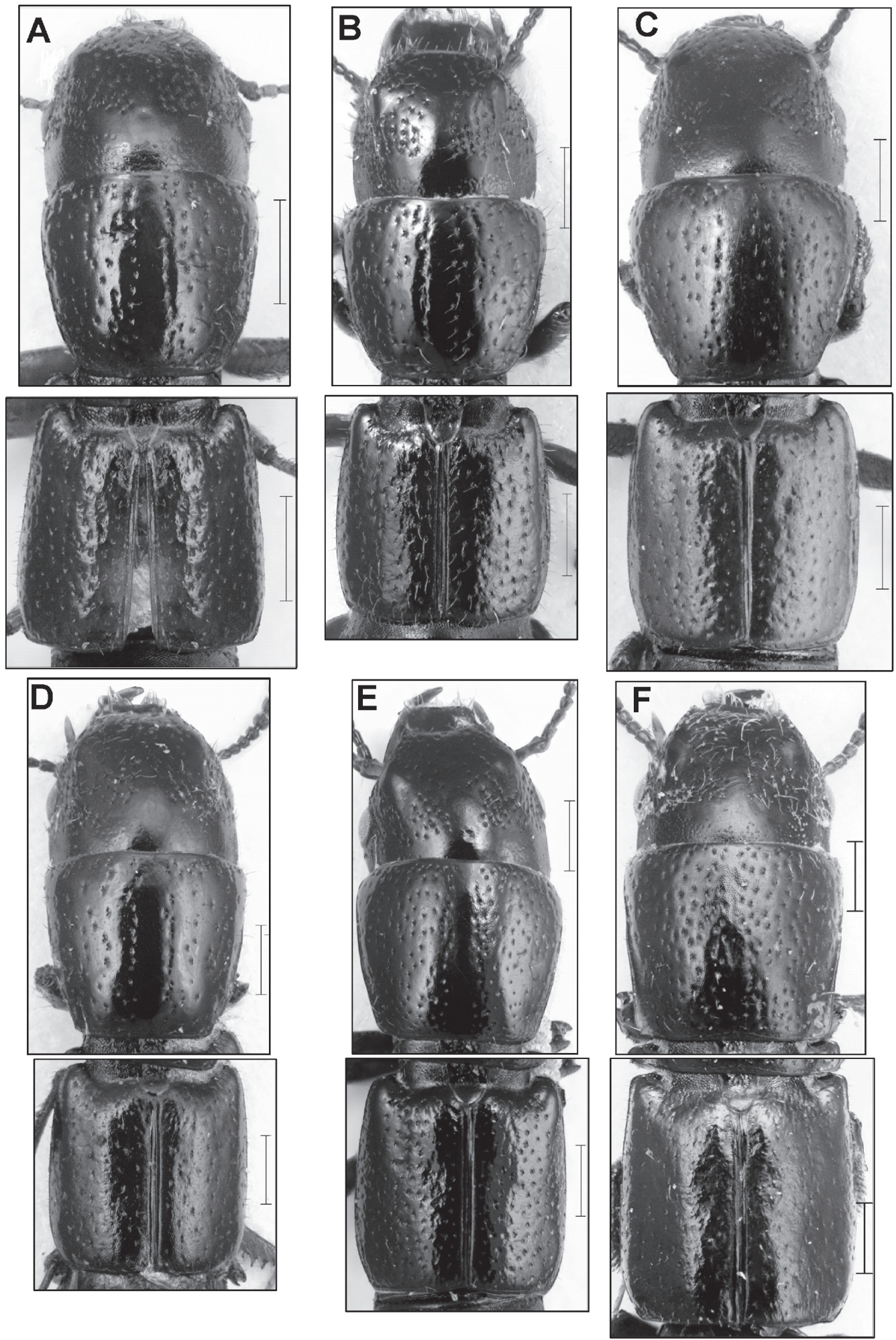

Fig. 99: Osoriellus-s. str.-group: Head, pronotum and elytra of Osoriellus latipes (A), O. mexicanus (B), O. brevipennis (C), O. argentinus (D), O. parcus (E), O. majusculus (F); scale bar: $0.5 \mathrm{~mm}$. 

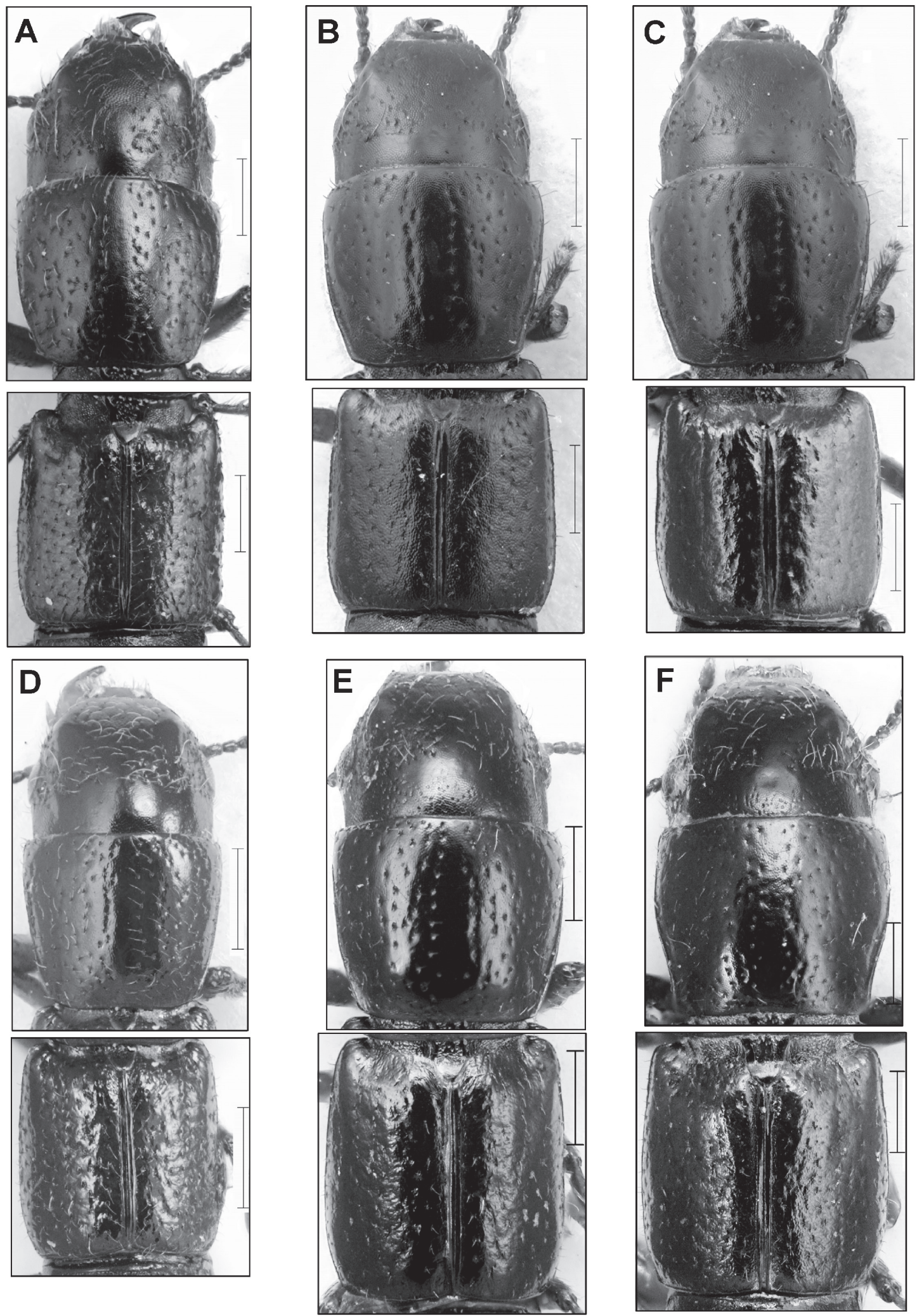

Fig. 100: Osoriellus-s. str.-group: Head, pronotum and elytra of O. schwarzi (A), O. opacus (B), O. rougemonti (C), O. debilis (D), O. seriatus (E), O. fumarius (F); scale bar: $0.5 \mathrm{~mm}$. 

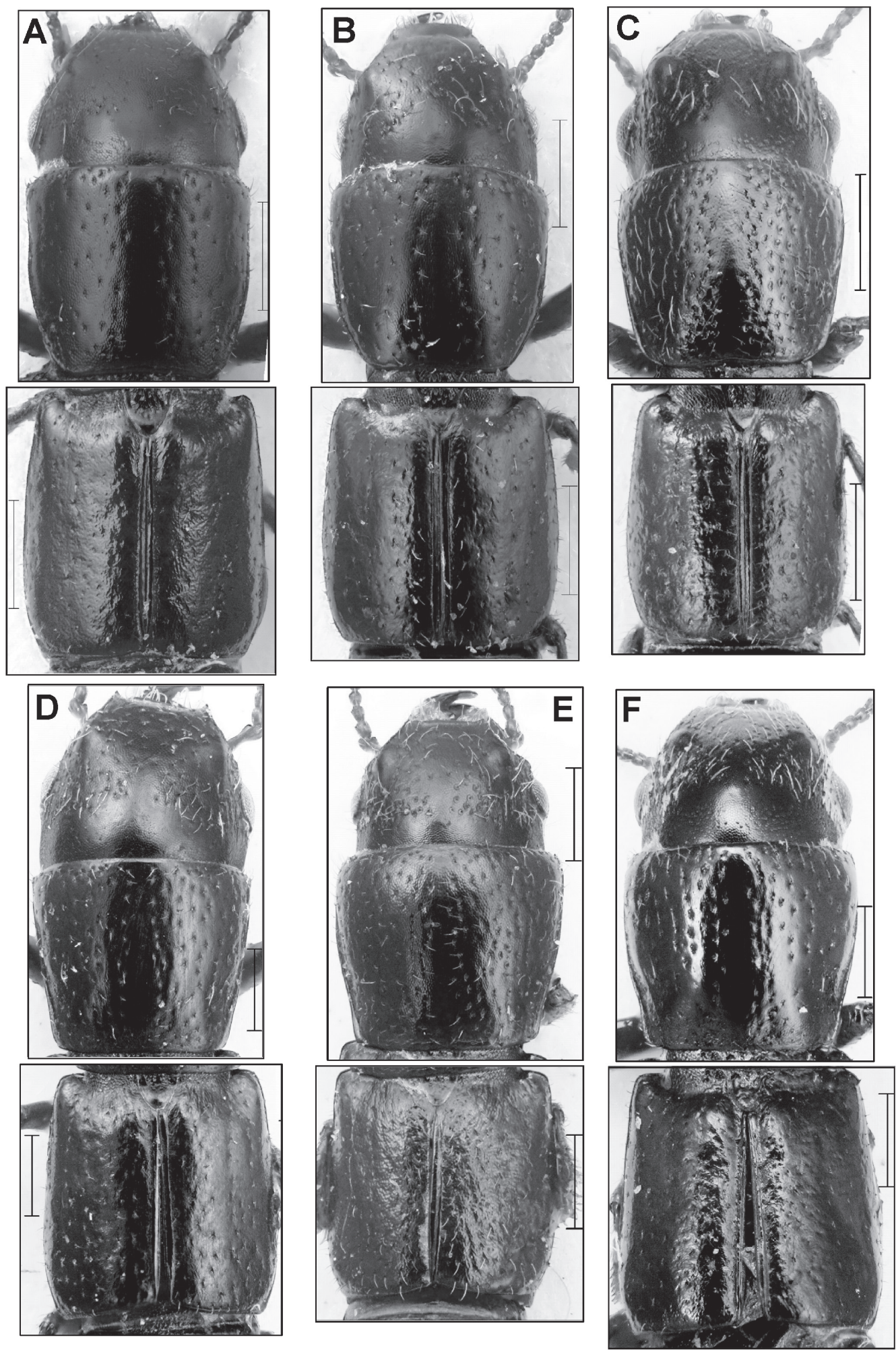

Fig. 101: Osoriellus-s. str.-group: Head, pronotum and elytra of O. trapezoides (A), O. haitiellus (B), O. multipunctatus (C), O. verhaaghi (D), O. rubripennis (E), O. caliginosus (F); scale bar: $0.5 \mathrm{~mm}$. 

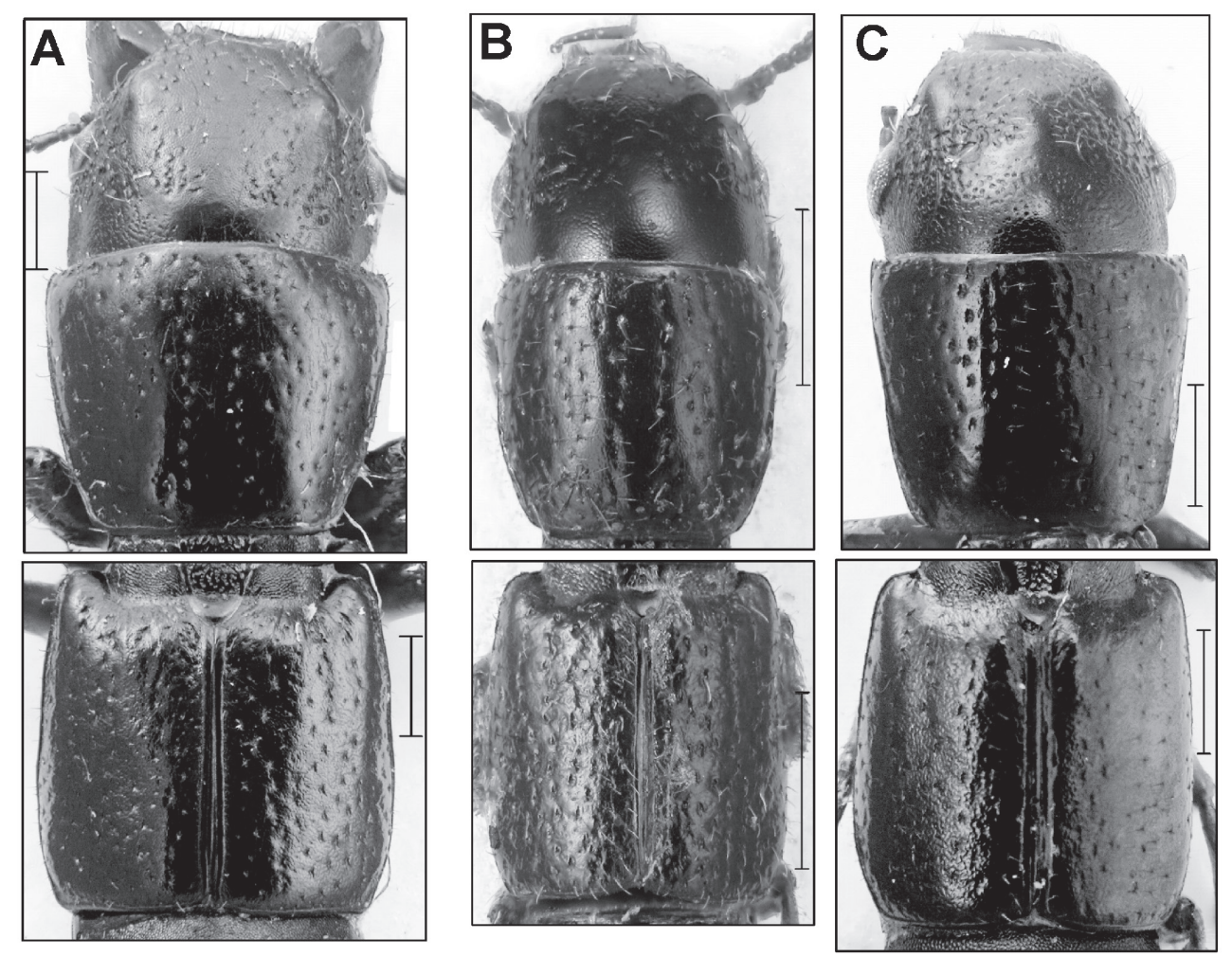

Fig. 102: Osoriellus-s. str.-group: Head, pronotum and elytra of O. crassus (A), O. lewisi (B), O. tunariensis (C); scale bar: $0.5 \mathrm{~mm}$. 


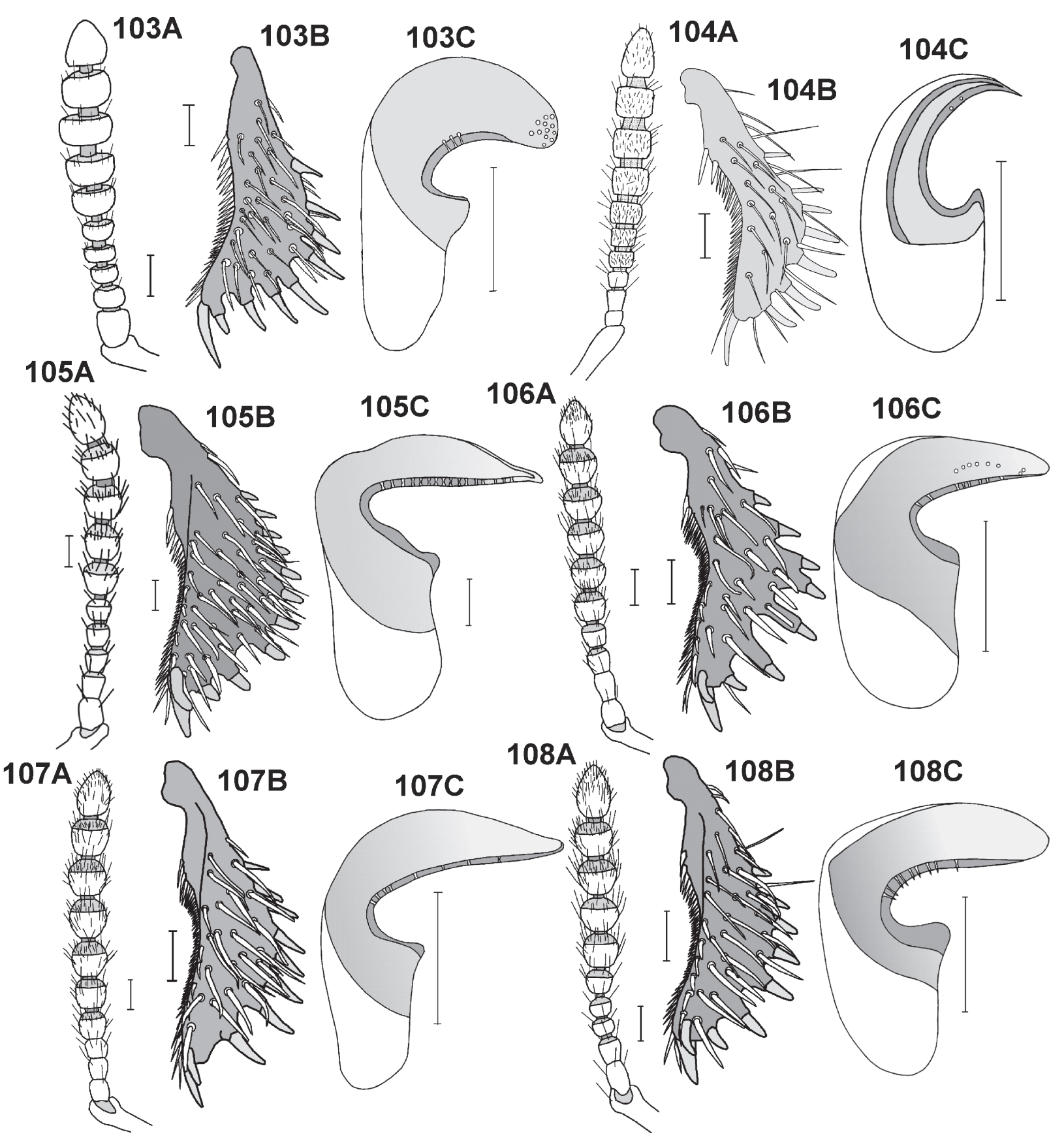

Fig. 103-108: Remaining-species-group: Osoriellus trinitatis (103), O. carinicollis (104), O. sticticus (105), O. acutus (106), O. orbiculatus (107), O. adustus (108); antenna (A), protibia (B), aedeagus in lateral aspect (C); scale bar: $0.1 \mathrm{~mm}$. 

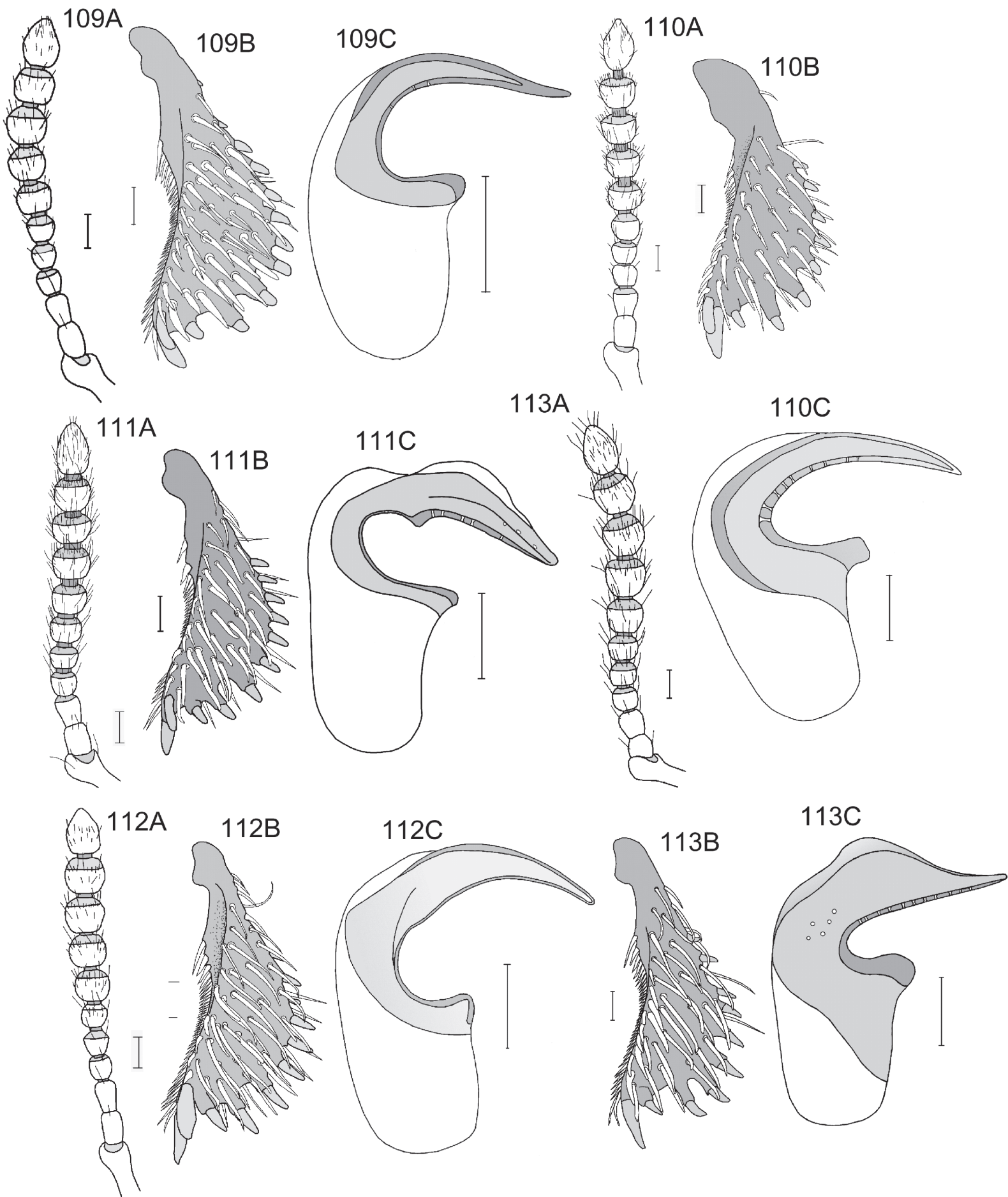

Fig. 109-113: Remaining-species-group: Osoriellus cordovensis (109), O. germanus (110), O. notmani (111), O. opacinotus (112), O. sexpunctatus (113); antenna (A), protibia (B), aedeagus in ventral and lateral aspects (C); scale bar: $0.1 \mathrm{~mm}$. 

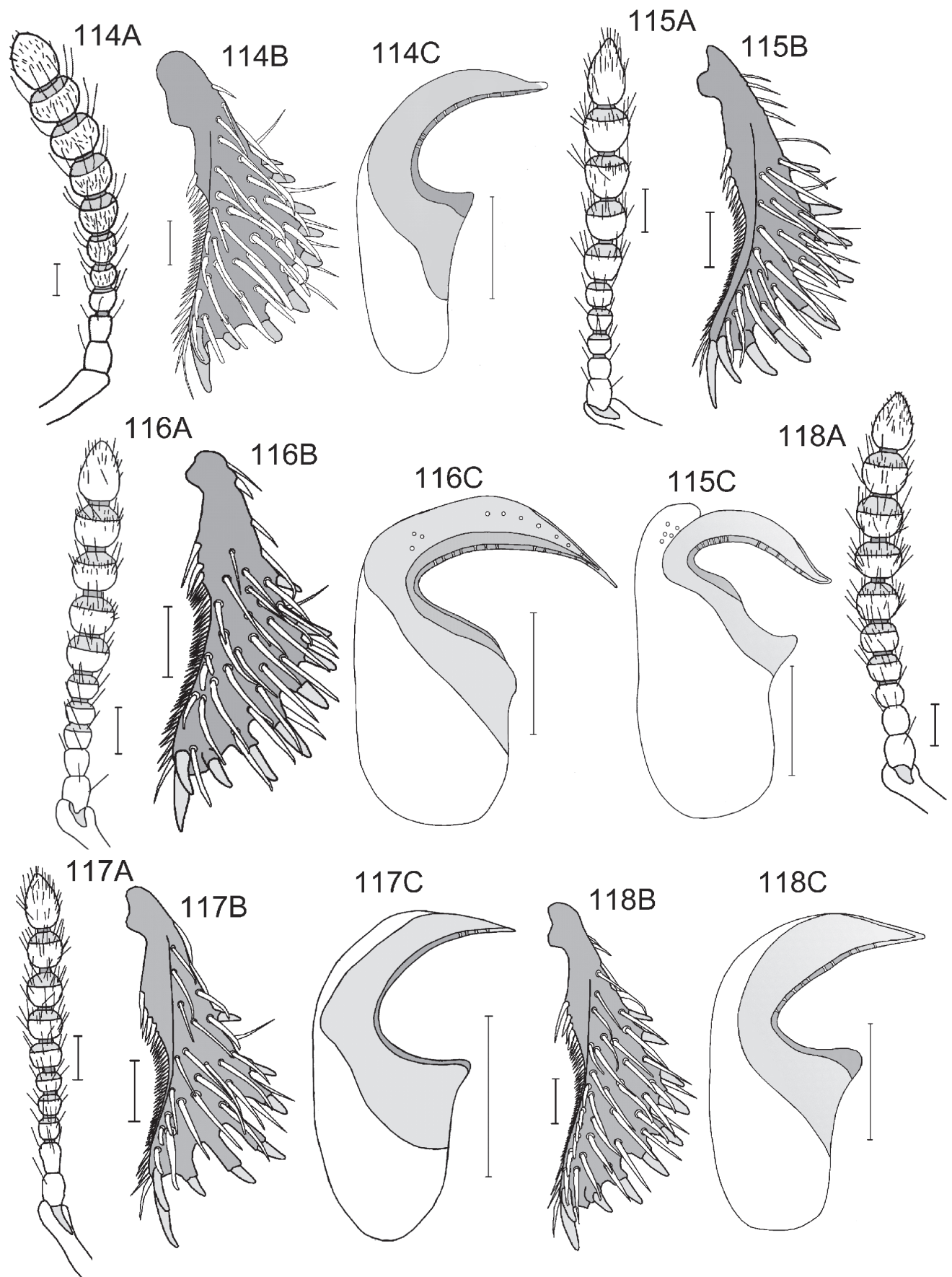

$118 \mathrm{C}$

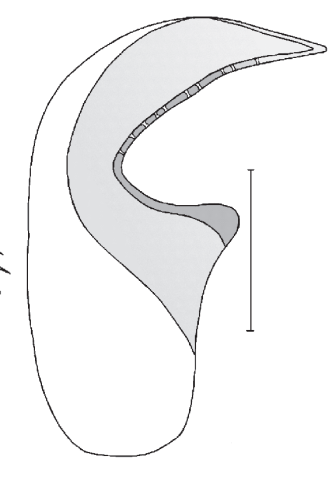

Fig. 114-118: Remaining-species-group: Osoriellus neotropicus (114), O. lescheni (115), O. loreti (116), O. digitatus (117), O. opticus (118); antenna (A), protibia (B), aedeagus in ventral and lateral aspects (C); scale bar: $0.1 \mathrm{~mm}$. 

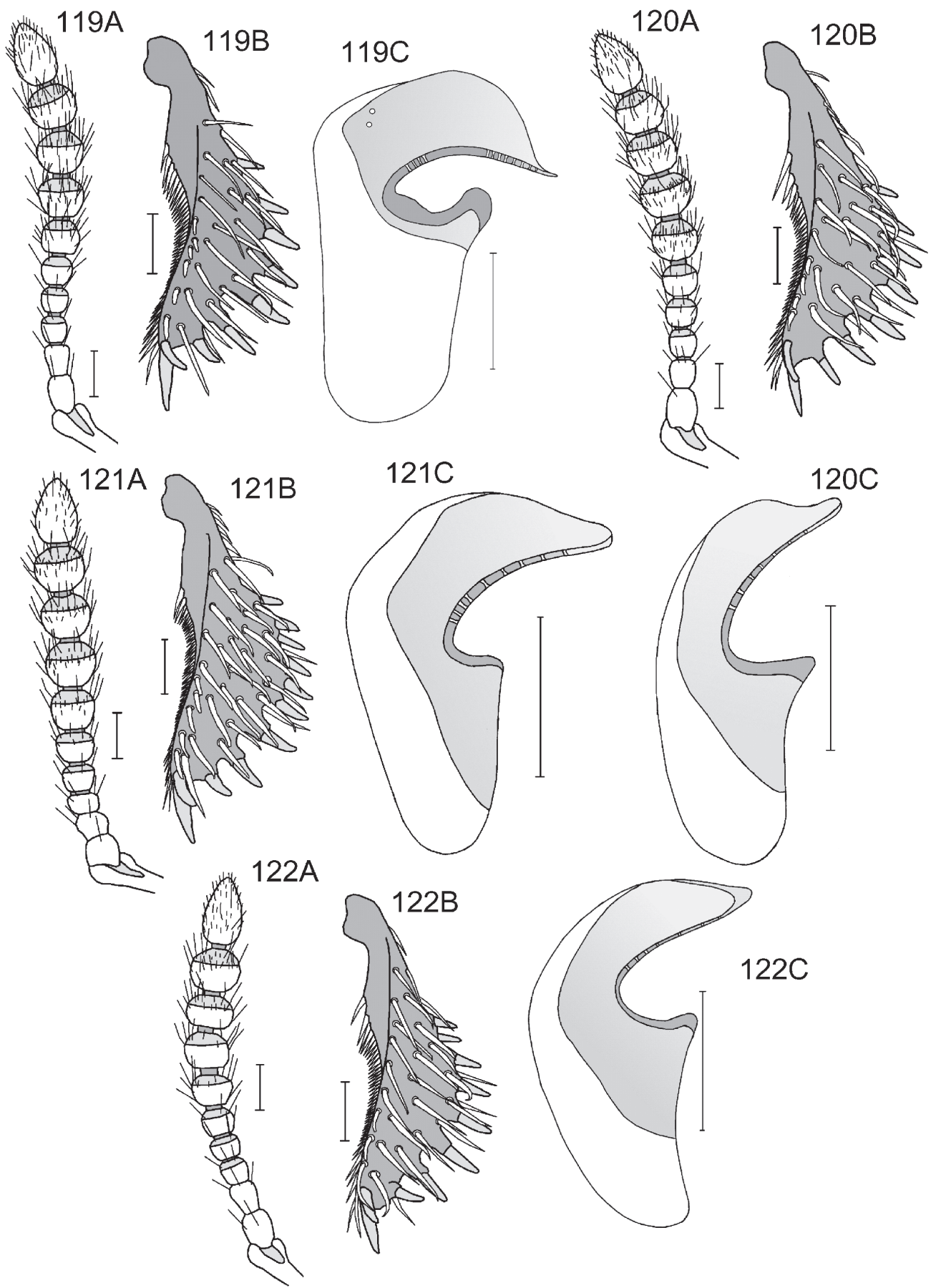

Fig. 119-122: Remaining-species-group: Osoriellus weberi (119), O. infuscatus (120), O. rectangulus (121), O. rufescens (122); antenna (A), protibia (B), aedeagus in ventral and lateral aspects (C); scale bar: $0.1 \mathrm{~mm}$. 

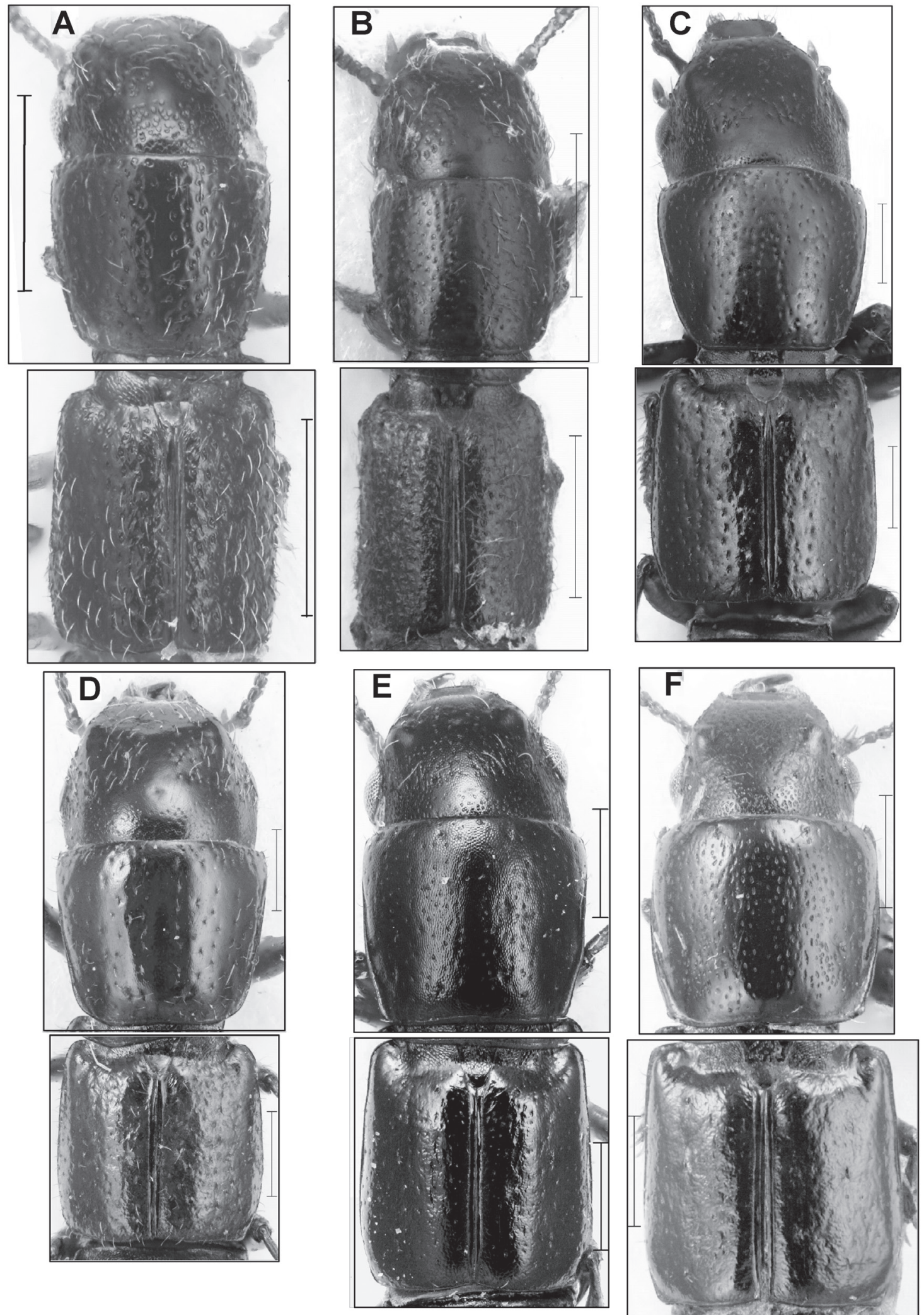

Fig. 123: Remaining-species-group: Head, pronotum and elytra of Osoriellus carinicollis (A), O. trinitatis (B), O. cordovensis (C), O. notmani (D), O. adustus (E), O. acutus (F); scale bar: $0.5 \mathrm{~mm}$. 

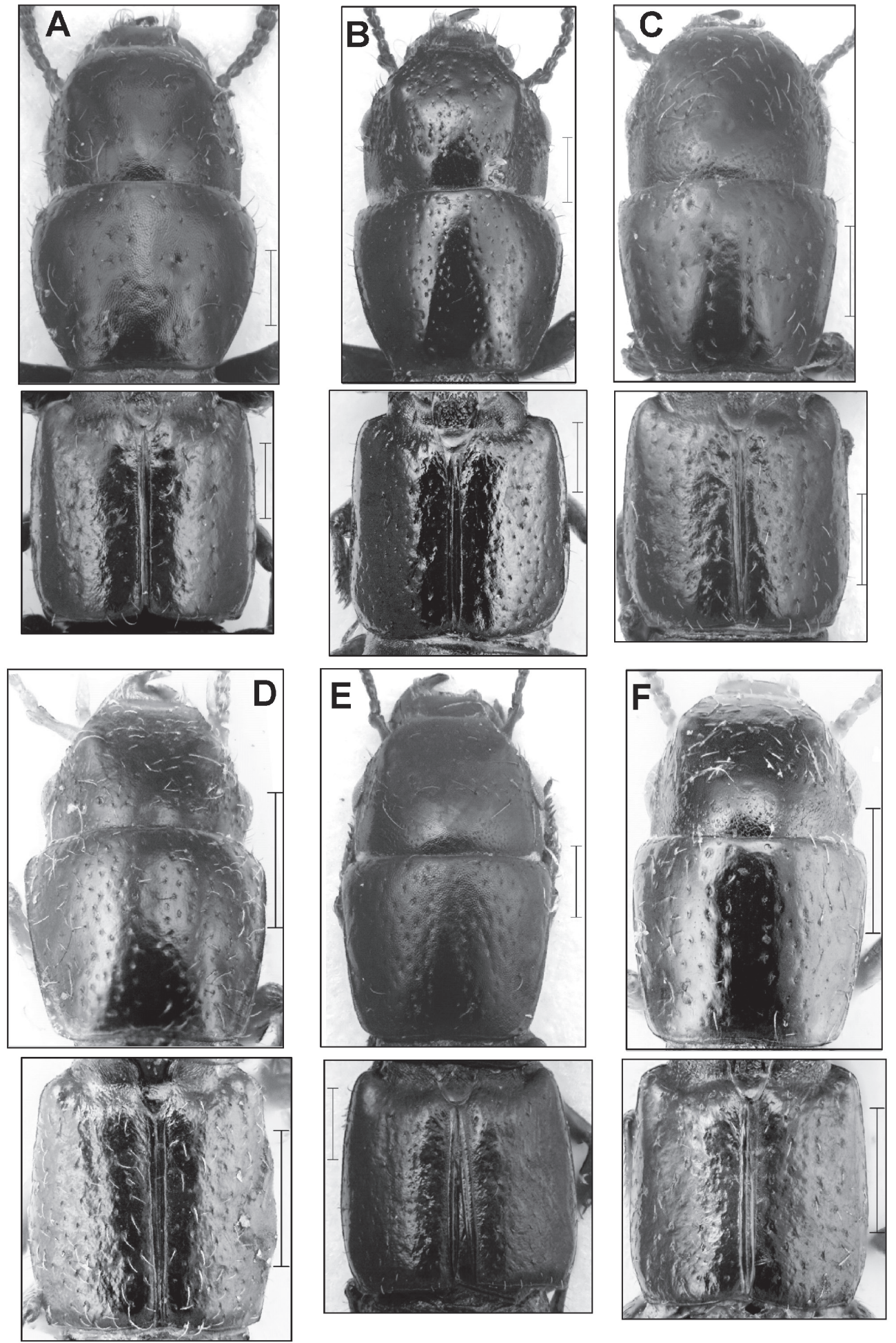

Fig. 124: Remaining-species-group: Head, pronotum and elytra of Osoriellus sexpunctatus (A), O. germanus (B), O. neotropicus (C), O. digitatus (D), O. opacinotus (E), O. infuscatus (F); scale bar: $0.5 \mathrm{~mm}$. 

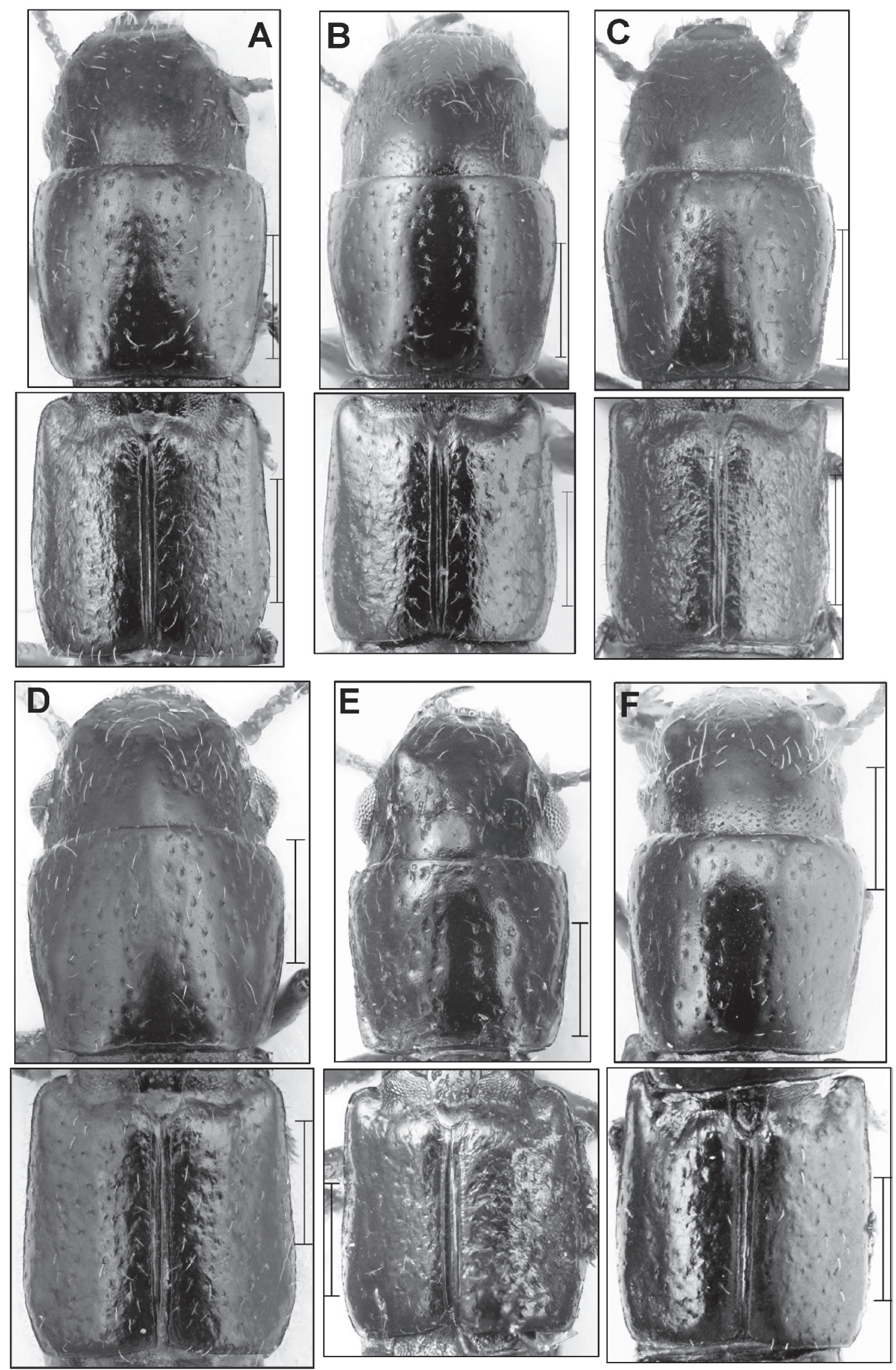

Fig. 125: Remaining-species-group: Head, pronotum and elytra of Osoriellus weberi (A), O. lescheni (B), O. loreti (C), O. opticus (D), O. orbiculatus (E), O. rectangulus (F); scale bar: $0.5 \mathrm{~mm}$. 

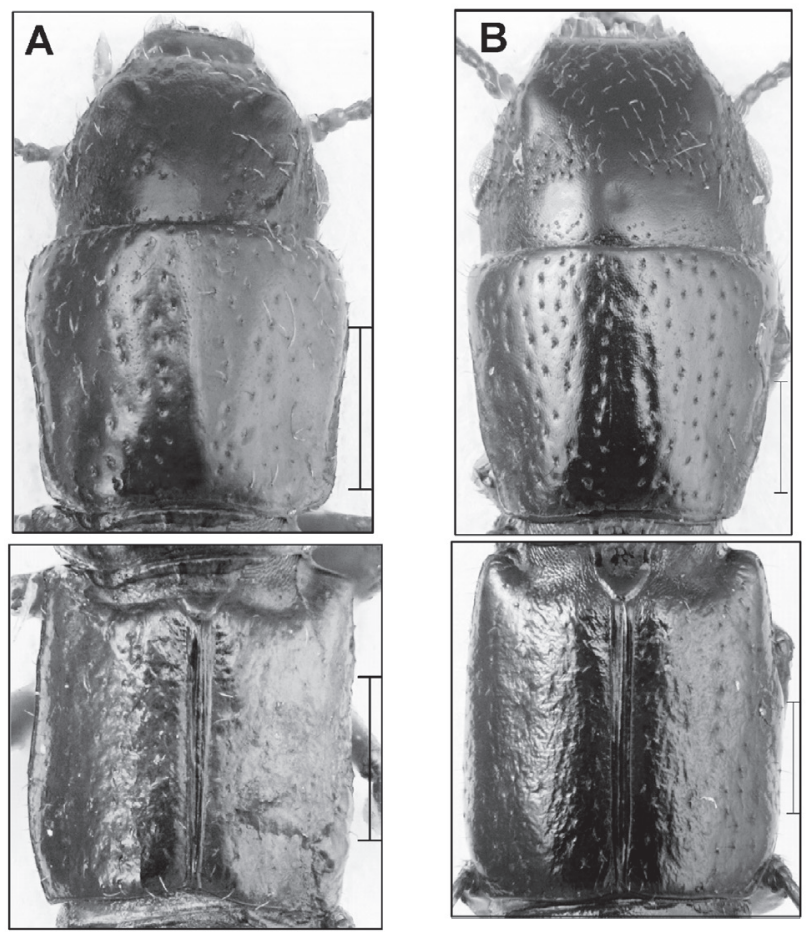

Fig. 126: Remaining-species-group: Head, pronotum and elytra of Osoriellus rufescens (A), O. sticticus (B); scale bar: $0.5 \mathrm{~mm}$. 

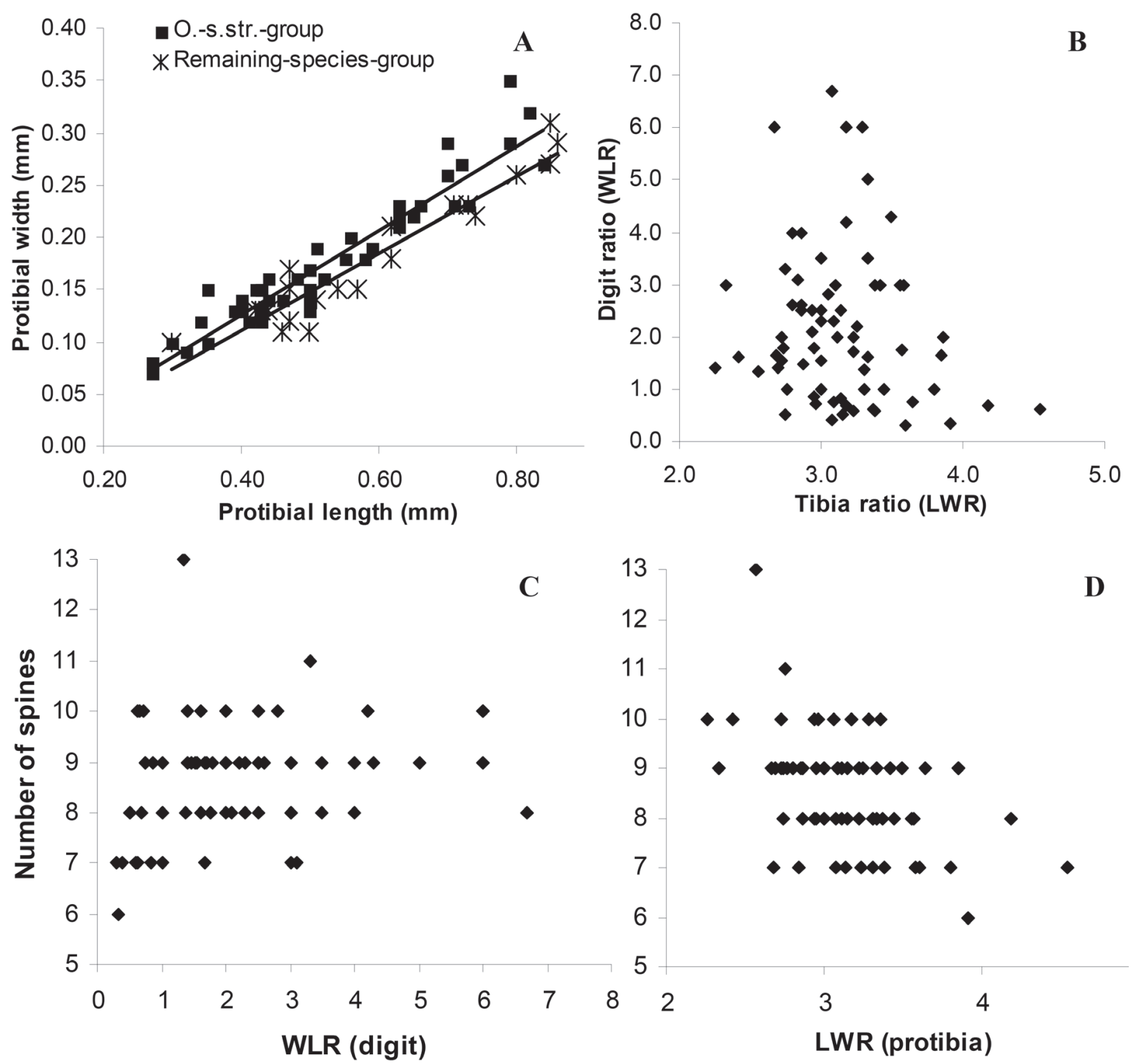

Fig. 127: Relations between between length and width of protibia (LWR) (A), between LWR of protibia and WLR of digit (B), between both WLR of digit (C) and LWR of protibia (D) and number of spines on the outer edge. 